

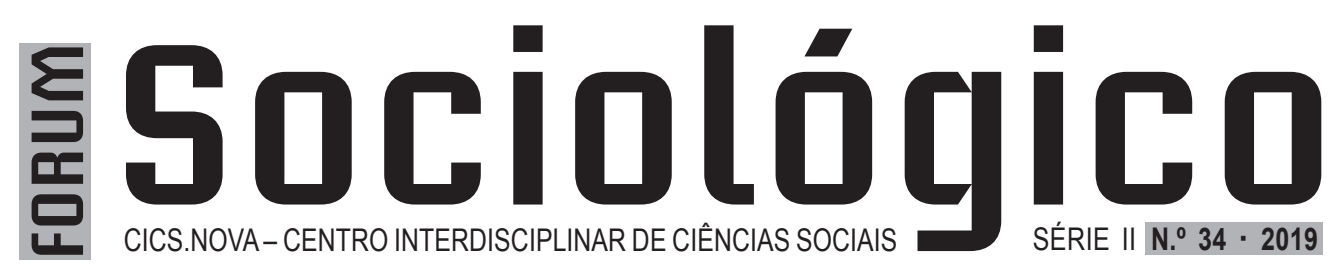




\title{
畺Sociológico
}

\author{
Fundador Moisés Espírito Santo \\ Diretora Ana Alexandre Fernandes \\ Conselho de Redação Ana Alexandre Fernandes (Diretora)। ISCSP-ULisboa; Beatriz Pa- \\ dilla | CIES-IUL; João Pedro Silva Nunes | NOVA FCSH; José Car- \\ los Marques I IP-Leiria; Luís Vicente Baptista I NOVA FCSH; Maria \\ João Bárrios I ISCSP-ULisboa; Miguel Chaves I NOVA FCSH; Patrícia \\ Pereira | NOVA FCSH
}

Assistente editorial

Conselho Editorial

Logotipo

Paginação

Revisão de texto

Propriedade do título

\section{Ana Camacho}

Alain Bourdin | IFU-França; Ana Nunes de Almeida | ICS-UL; Anália Torres | ISCSP-ULisboa; António Firmino da Costa | CIES-IUL; Carlos Miguel Ferreira | ULHT; Graça Índias Cordeiro | CIES-IUL; Isabel Dias | FLUP; Joan Josep Pujadas |URV-Espanha; João Gonçalves | NOVA FCSH; João Teixeira Lopes | FLUP; José Luis Vieira | UDC-Espanha; Loïc Wacquant | UC, Berkeley-USA; Luc Boltanski | EHESS-GSPM; Tim Sieber | UMass, Boston-USA

Carolina Basto

Ana Paula Silva

Anabela Prates Carvalho

CICS.NOVA - Centro Interdisciplinar de Ciências Sociais Edifício I\&D, Avenida de Berna, n. ${ }^{\circ} 26$ 1069-061 Lisboa Telefone: 00351217908300 (ext. 1488)

Fax: 00351217908308

Email: forum@fcsh.unl.pt

Site: http://journals.openedition.org/sociologico/

Apoios Publicação subsidiada por Fundos Nacionais ao abrigo do projeto UID/ /SOC/04647/2013 da FCT - Fundação para a Ciência e a Tecnologia.

Depósito Legal N. ${ }^{\circ} 64682 / 93$

ISSN $\quad 0872-8380$

e-ISSN 2182-7427 


\section{ÍNDICE}

Editorial

DOSSIÊ: HABITAÇÃO NAS ÁREAS URBANAS DE LSBOA E PORTO: DA COMUNIDADE AOS DECISORES

Política de habitação social em Portugal: de 1974 à actualidade

Social housing policy in Portugal: from 1974 to the present

Gonçalo Antunes...

Um lugar em produção: o caso da Cova da Moura

A place in the making: the case of Cova da Moura

Sílvia Jorge e Júlia Carolino

Espaços nem-nem - nem públicos nem privados em edifícios de habitação social de grande porte

Spaces neither-nor - neither public nor private in large-scale social housing buildings

Teresa Madeira da Silva

Necessidade, oportunidade e ilegalidade em habitação - alojamento local e tendências contemporâneas

Need, opportunity and illegality in housing - short-term rentals and contemporary trends

Inês Calor e Mateus Magarotto.

O papel do crowdfunding na dinamização do setor imobiliário

The role of crowdfunding in promoting real estate industry

Miguel Neves Matias

Entre as práticas e as políticas. O programa Habitar Porto

Between practices and policies. Programme Habitar Porto

Aitor Varea Oro, Ana Pinheiro e Mariana Almeida.

Acesso à habitação por todos e para todos? Paradigmas e paradoxos da actualidade portuguesa Access to housing by all and for all? Today's paradigms and paradoxes in Portugal

Silvia Leiria Viegas

\section{Artigo}

Promoção de estilos de vida saudáveis: uma distinção social?

Promotion of healthy lifestyles: a social distinction?

Pedro Saraiva. 


\section{EDITORIAL}

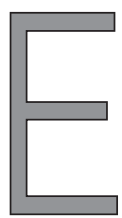

ste primeiro número de 2019 da Revista Forum Sociológico integra o dossiê temático "Habitação nas áreas urbanas de Lisboa e Porto: Da comunidade aos decisores", coordenado por Gonçalo Antunes, Madalena Corte-Real, Maria João Gomes e Marianna Monte, composto por artigos produzidos a partir de contributos apresentados e debatidos numa conferência organizada no âmbito do projeto Urbanólogo em Fevereiro de 2018.

Em 2017, a equipa do Urbanólogo decidiu alargar o seu raio de ação e, além de dinamizar uma plataforma online ${ }^{1}$ para divulgação de informação relacionada com os campos da habitação, arquitetura, arquitetura paisagista, arte, património, mobilidade, ambiente, tecnologia, turismo, dinâmicas sociais, interculturalidade, transformação urbana, entre outros, aventurou-se na organização de eventos relacionados com temáticas caras aos estudos urbanos.

O primeiro tema foi a habitação, com a organização da conferência "Habitação in foco: da comunidade aos decisores", cuja sessão de abertura contou com a participação de Ana Pinho (secretária de Estado da Habitação), Helena Roseta (deputada da Assembleia da República), Alexandra Gesta (presidente do Instituto da Habitação e da Reabilitação Urbana), Fernando Paulo Sousa (vereador da Habitação da Câmara Municipal do Porto) e Gonçalo Antunes (docente e investigador da NOVA FCSH). Ao longo do dia estiveram ainda presentes outros oradores convidados que aprofundaram o debate sobre as "questões contemporâneas", a "gestão do parque habitacional público" e as "comunidades locais". O sucesso do evento - medido pelo elevado número de presenças e também pelas referências em órgãos de comunicação social - contribuiu para dar ânimo ao novo caminho que o Urbanólogo pretendia percorrer.

\section{Porquê a habitação?}

Nos últimos anos, a habitação regressou à agenda política, mediática e académica. A nível internacional, depois dos esforços realizados no âmbito do Estado-providência no rescaldo da Segunda Grande Guerra, a questão das políticas sociais de habitação viu a sua importância ser reduzida, de acordo com o modelo político-ideológico instituído por Margaret Thatcher, no Reino Unido, e Ronald Reagan, nos Esta- dos Unidos da América. No contexto português, após o esforço para a demolição dos bairros de habitações precárias nas duas grandes áreas metropolitanas, no âmbito do Programa Especial de Realojamento, também a questão das políticas de habitação foi reduzida à temática da reabilitação, que dominou os instrumentos políticos e os documentos estratégicos criados no início do século XXI.

Circunscrevendo-o ao contexto nacional, o problema da habitação continua a afetar os segmentos populacionais mais carenciados, sobretudo nos bairros de habitações precárias que se mantêm (e. g., bairro 6 de Maio, bairro da Torre, etc.) e em áreas urbanas degradadas (e. g., bairro da Liberdade, bairro das Galinheiras, ilhas do Porto, etc.). A estas questões, acrescentam-se, ainda, as áreas urbanas de génese ilegal, que aguardam regularização e requalificação, e, em particular, os novos desafios do século XXI, como a gentrificação, a financeirização, a especulação imobiliária, o estímulo do mercado de arrendamento, o crédito à habitação, as taxas de esforço excessivas, o alojamento local e a turistificação (ou a tristificação, como lhe chamou Helena Roseta na conferência acima referida) do centro histórico das principais cidades portuguesas.

Ao contrário do que sucedia na última década do século $X X$, já não estamos apenas no âmbito de uma questão de insalubridade que afecta os segmentos populacionais mais carenciados, mas no de um problema que atinge também famílias e indivíduos da classe média, que não conseguem manter a sua residência nas grandes cidades. Quer isto dizer que, apesar de o problema da habitação ter estado esquecido, este nunca desapareceu, apenas se alargou a um segmento populacional, a classe média, que o trouxe novamente à discussão pública.

Recentemente, o XXI Governo da República Portuguesa apresentou a Nova Geração de Políticas de Habitação, que pretende reformar várias políticas existentes no domínio da habitação social, do apoio ao arrendamento e da reabilitação. Destaca-se, ainda, o Levantamento Nacional das Necessidades de Realojamento Habitacional, organizado pelo IHRU no início de 2018, que identificou cerca de 25000 famílias a necessitar de realojamento.

A crescente atenção informativa na imprensa reflete a importância e o desenvolvimento do tema da habitação no contexto nacional. Tendo por base a consulta digital de quatro órgãos de comunica- 
ção - Público, Correio da Manhã, Expresso e Jornal de Notícias - nos últimos 10 anos, destaca-se o aumento exponencial do número de notícias sobre esta temática². Entre 2009 e 2016 há um registo médio de 20 notícias por ano, em 2017 foram publicadas 111, e em 2018, 446 notícias. Durante este período, verifica-se uma alteração do foco dos textos, passando do predomínio de questões relacionadas com a habitação social para o destaque de temas como a legislação e o mercado imobiliário. O ano de 2018 é aquele em que o tema legislação domina as notícias sobre habitação. Este assunto surge associado aos tópicos habitação acessível, aumento de preço de aquisição e arrendamento, e mercado imobiliário.

\section{Habitação nas áreas urbanas de Lisboa e Porto: Da comunidade aos decisores}

O dossier inicia com uma reflexão sobre a evolução das políticas de habitação social no Portugal democrático, de autoria de Gonçalo Antunes. Este artigo percorre o alargado leque de políticas de habitação social promulgadas nas últimas décadas e avalia as suas repercussões no território do ponto de vista urbano e social, tecendo, no final, várias observações e considerações sobre o domínio analisado.

O segundo artigo, da autoria de Sílvia Jorge e Júlia Carolino, convoca os conceitos de "lugar" e de "direito ao lugar" para explorar diferentes leituras e perceções sobre o bairro da Cova da Moura. As autoras propõem uma renovada análise sociopolítica do território, baseada na observação da realidade local, plural e negociada, que se distancia das leituras negativas mais generalizadas.

Segue-se o artigo de Teresa Madeira da Silva, que analisa os "espaços nem-nem", "nem públicos nem privados". A autora avalia alguns modelos arquitetónicos e urbanísticos assumidos em projetos de habitação social, em particular os espaços de circulação abertos que literatura anglo-saxónica denomina como streets in the air. Com este artigo, Madeira abre uma reflexão sobre os espaços de circulação e comunicação em galeria no contexto português, tendo como objeto conjuntos de habitação social construídos na freguesia de Marvila, Lisboa.

Como não poderia deixar de ser, este número conta também com um debate sobre o recente fenómeno de short-term rental. O artigo de Inês Calor e Mateus Magarotto procura avaliar se o sistema urbano português está preparado para a mudança de paradigma que as novas ferramentas e plataformas tecnológicas potenciam no setor da habitação, transformando frações habitacionais de índole residencial em locais de arrendamento efé- mero vocacionado para turistas. Os desequilíbrios gerados e as tensões sociais e urbanas são também debatidas pelos autores.

Também relacionado com novas tendências do mercado imobiliário, Miguel Neves Matias discute sobre a forma como o crowdfunding e as novas tecnologias podem afirmar-se enquanto concorrente dos instrumentos bancários tradicionais de financiamento. Matias teoriza sobre esta nova tendência de mercado e dá como prática vários exemplos internacionais que interessa conhecer e compreender.

Adotando também novos modelos de ação - ou talvez apenas repescando de forma inteligente aquilo que é essencial na atuação em meio urbano - , Aitor Varea Oro, Ana Pinheiro e Mariana Almeida desenvolvem um artigo com base na experiência prática e vivida do programa Habitar Porto. Este agente do terceiro setor procura democratizar o acesso à habitação, agindo diretamente com a população e procurando encontrar soluções sustentáveis para os destinatários, sobretudo residentes nas conhecidas ilhas portuenses.

Por fim, Sílvia Leiria Viegas traz a este número a densificação de conceitos preciosos como o direito à habitação, o acesso à habitação e o direito à cidade e autores como Michel Foucault, Slavoj Žižek, Henri Lefebvre e David Harvey. O artigo desenvolve-se em torno da ótica da defesa dos direitos humanos, do acesso a habitação condigna por parte da população com menor rendimento e das minorias, examinando-se, ainda, inclusões e exclusões criadas pelos programas que têm sido aplicados em Portugal.

Fechamos este número 34 da Fórum com o artigo "Promoção de estilos de vida saudáveis: Uma distinção social?", situado fora do âmbito do dossiê temático. Neste texto, Pedro Saraiva propõe ao leitor um debate baseado em dois conjuntos de estudos empíricos que mostram, por um lado, a importância da distinção social no âmbito dos estilos de vida saudável e, por outro, atestam a crescente massificação dos produtos e serviços a eles associados na sociedade de consumo contemporânea.

\section{Notas}

1 https://www.urbanologo.com

2 Imagens síntese da análise de imprensa realizadas pelo coletivo associado ao Urbanólogo disponíveis em https:// www.urbanologo.com/habitacao

Gonçalo Antunes, Madalena Corte-Real, Maria João Gomes, Marianna Monte e Patrícia Pereira 


\title{
POLÍTICA DE HABITAÇÃO SOCIAL EM PORTUGAL: DE 1974 À ACTUALIDADE SOCIAL HOUSING POLICY IN PORTUGAL: FROM 1974 TO THE PRESENT
}

\author{
Gonçalo Antunes \\ Centro Interdisciplinar de Ciências Sociais (CICS.NOVA), Faculdade de Ciências Sociais e Humanas (NOVA FCSH)
}

\begin{abstract}
Resumo
Quando, em 1974, se deu a Revolução de 25 de Abril, o "problema da habitação" estava entre os maiores atrasos do nosso país. O presente artigo tem como objectivo analisar as políticas de habitação social promulgadas em Portugal desde Abril de 1974. O estudo incide, em particular, no quadro legislativo das políticas de habitação social, de promoção directa e de promoção indirecta, pretendendo-se compreender a evolução temporal do "direito à habitação" na democracia portuguesa. A metodologia adoptada assenta na interpretação crítica dos diplomas legais publicados e dos respectivos programas habitacionais, assim como na pesquisa de estudos que analisam do ponto de vista teórico e prático as políticas habitacionais abordadas ao longo do trabalho. A análise cronológica, que tem como base a evolução legislativa, demonstra que no nosso país as políticas de habitação social foram essencialmente casuísticas, circunstanciais e pontuais, não se tendo criado a médio ou a longo prazo uma estratégia de promoção de habitação social apoiada pelo Estado.
\end{abstract}

Palavras-chave: políticas de habitação; direito à habitação; habitação social

\begin{abstract}
When the revolution of April 25 occurred in 1974, the "housing problem" was one of the main social issues at the time in Portugal. The purpose of this article is to analyze the social housing policies promulgated in Portugal since April 1974. The study focuses on social housing legislation, aiming to understand the evolution of the "right to housing" in the Portuguese democracy. The methodology adopted is based on the critical interpretation of the legislation and the housing programs created, as well as on the analysis of studies about the theoretical and practical results of the housing policies addressed throughout the work. The chronological analysis, based on the legislative evolution, shows that in Portugal social housing policies were essentially casuistic and circumstantial, without a medium-term or long-term strategy for the promotion of social housing supported by the State.
\end{abstract}

Keywords: housing policies; right to housing; social housing

Políticas de habitação: propostas de análise e interpretação

O percurso das políticas de habitação social em Portugal tem sido estudado ao longo das últimas décadas, com abordagens diferenciadas que procuram compreender a evolução das políticas de habitação nos domínios da Sociologia, Arquitectura, Urbanismo, Geografia, Ciência Política, entre outros. Este trabalho segue, assim, uma linha interpretativa que encontra paralelo em outros trabalhos, embora com abordagens científicas, metodológicas e períodos diferenciados.

É disto exemplo o trabalho de Baptista (1999), que se focou nas políticas de habitação social promulgadas durante o Estado Novo e, em particular, sobre a política de casas económicas. Outros autores, como Gros (1994), também analisaram a história do alojamento social no período da ditadura, ou Silva (1994a, 1994b, 1994c, 1997), que relacionou as políticas de habitação, urbanas e fundiárias para o mesmo período. 
No mesmo sentido, também Serra (2002) analisou a questão das políticas de habitação, interligando as estratégias habitacionais aplicadas na segunda metade do século XX. Também o IHRU, num trabalho coordenado por Portas (2013), analisou algumas das principais políticas de habitação social - assim como o problema da habitação - na transição entre a ditadura e a democracia. Por sua vez, Ferreira $(1987,1993)$ focou-se no estudo sequencial das políticas de habitação promulgadas nas primeiras duas décadas após a revolução, assim como naquilo que ainda faltava fazer no início da década de 1990. Numa análise mais relacionada com a arquitectura, também Coelho $(2006,2009)$ examinou o objecto construído nas políticas de habitação social na transição entre os séculos XX e XXI. Mais recentemente, Guerra (2011) reflectiu sobre os novos caminhos para as políticas de habitação e Acciaiuoli (2015) observou a história da habitação em Lisboa entre o início do século XIX e o final do século XX, numa abordagem relacionada com o mercado de habitação privado e de arrendamento.

Em 2018, surgiram dois trabalhos que analisaram as políticas de habitação social promulgadas em Portugal. Em Novembro, Antunes (2018) publicou um trabalho que analisa de forma sistematizada as políticas de habitação promulgadas em território nacional nos últimos duzentos anos, no seu tríplice de habitação social, arrendamento e reabilitação. No mês seguinte, num projecto institucional promovido pelo Instituto da Habitação e da Reabilitação Urbana (IHRU) e coordenado por Agarez (2018), foi publicado um estudo que engloba análises às políticas habitacionais promulgadas nos últimos cem anos e respectivos resultados práticos, recorrendo, como no caso anterior, a informação estatística, acervos, arquivos, entre outros elementos que permitem a interpretação das políticas de habitação e respectivos resultados.

Este pequeno sintagma de contributos que analisam no todo ou em parte a sequência de políticas de habitação social em Portugal não esgota, como é óbvio, as várias centenas de estudos científicos que têm analisado os objectivos e os resultados de políticas de habitação particulares, de determinados bairros construídos e das vivências sociais e urbanas daí resultantes.

No que respeita à experiência internacional, são conhecidos os trabalhos que têm promovido o debate sobre a experiência e a evolução do quadro legal das políticas de habitação, destacando-se, por exemplo, vários estudos publicados sobre esta matéria no Reino Unido (Malpass \& Murie, 1999; Hughes \& Lowe, 2000; Lowe, 2011; Lund, 2016), ou de trabalhos comparativos entre diferentes países europeus (Dias, 1994; Balchin, 1996; Allen, Barlow, Leal, Maloutas \& Padovani, 2004; McCrone \& Stephens, 2017; Bargelli \& Heitkamp, 2018).

\section{Âmbito e metodologia}

O presente artigo tem como objectivo analisar a evolução do quadro legal das políticas de habitação social desde o 25 de Abril de 1974, numa análise de natureza voluntariamente teórica, qualitativa e ensaística. Para tal, o trabalho assenta na leitura crítica dos vários diplomas legislativos promulgados nos últimos 45 anos de democracia, mas, também, na análise dos seus resultados num domínio de análise eminentemente cronológico e sócio-urbano. Além da fundamental interpretação dos diplomas ${ }^{1}$, realizou-se, paralelamente, a necessária pesquisa bibliográfica de estudos que analisam do ponto de vista teórico e prático as políticas habitacionais abordadas ao longo do trabalho, tendo-se utilizado, ainda, dados estatísticos disponibilizados pelo Instituto Nacional de Estatística (INE) e pelo Instituto da Habitação e Reabilitação Urbana (IHRU).

Sobre o estudo das políticas de habitação, chama-se a atenção sobre as armadilhas conceptuais e metodológicas que a análise encerra. Como afirma Baptista (2001), colocam-se vários desafios à análise das políticas de habitação, pois, em grande medida, o seu estudo está dependente dos dados produzidos por organismos institucionais, que podem ser levados a realizar interpretações propagandísticas para legitimar as opções tomadas. Esta situação é especialmente evidente, por exemplo, nos preâmbulos da legislação produzida, que faz uso frequente de fundamentação e justificação político-ideológica para a criação de novos programas ou a revogação dos já existentes. A análise crítica, a multidisciplinariedade de conhecimentos e o cruzamento e a validação múltipla das informações devem, assim, alicerçar qualquer trabalho que pretenda analisar o quadro legal das políticas de habitação.

Do ponto de vista conceptual, entende-se neste trabalho o conceito de habitação social num sentido alargado de interesse social, incluindo todos os imóveis com vocação habitacional que para a sua construção beneficiam (ou beneficiaram) de apoios directos ou indirectos da administração pública, independentemente da variedade de modelos de produção, de financiamento, de gestão, de público-alvo e de regimes de ocupação.

O artigo está estruturado da seguinte forma: a) fundamentação do quatro teórico do trabalho e de estudos que analisam a evolução das políticas de habitação a nível nacional e internacional; b) análise do período revolucionário; c) apreciação das disposições constitucionais; d) interpretação do desenvolvimento das políticas de habitação social, debatendo-se a promoção indirecta e a promoção directa; e) reflexões finais em torno do percurso das políticas de habitação social em portugal. 


\section{As políticas de habitação desde Abril de 1974}

A revolução e o problema da habitação

No período imediato à revolução o problema da habitação incluiu-se nas principais reivindicações da população portuguesa, sobretudo nas duas maiores cidades do país, Porto e Lisboa. No turbilhão de acontecimentos que se sucederam nos meses seguintes ao 25 de Abril, ocorreram dezenas de acções populares, mobilizações sociais e manifestações que reivindicavam melhores condições de vida e que pretendiam trazer o problema da habitação para a ordem do dia (Cerezales, 2003; Bandeirinha, 2007; Pinto, 2008; 2013; Acciaiuoli, 2015).

O exemplo mais expressivo destas acções ficou plasmado na ocupação de casas devolutas, o que se traduziu num dos fenómenos urbanos mais singulares do pós-25 de Abril. Para além destas acções espontâneas de índole anarco-populista (Santos, 2017), o período revolucionário ficou ainda marcado pela organização comunitária. Afirma Pinto (2008, 2013) que entre Abril de 1974 e Julho de 1976 foram criadas 166 organizações comunitárias só na cidade de Lisboa, entre comités de ocupantes, comissões de moradores, de inquilinos, entre outros.

Foi neste ambiente de participação activa das comunidades locais que se criaram as condições ideais para a implementação de políticas de habitação que instigassem a participação directa da população. Tal viria a materializar-se no Verão de 1974, com a criação do Serviço de Apoio Ambulatório Local (SAAL). ${ }^{2}$ O SAAL pretendia contribuir para a diminuição do número de bairros de habitações precárias, tendo rompido com diversos paradigmas das intervenções do Estado Novo. A metodologia SAAL rejeitava os processos tipicamente top-down e privilegiava uma abordagem bottom-up, que pretendia fomentar a governação de proximidade e a participação da população. Para tal, eram constituídas brigadas ambulatórias que funcionavam na órbita do Fundo de Fomento da Habitação (FFH), sendo compostas por equipas multidisciplinares (Bandeirinha, 2007). As brigadas entravam em diálogo directo com as comissões de moradores, debatendo-se em sessões de esclarecimento as tipologias habitacionais a serem construídas no novo bairro, de forma a que estivessem de acordo com as expectativas da população que, em muitas situações, era convidada a participar na construção das casas e do bairro, num modelo de autoconstrução.

A metodologia aplicada no SAAL pode ser catalogada com a democracia directa e participativa, que perdeu força à medida que a democracia representativa se consolidou no nosso país, ao que se juntava um clima político-partidário que olhava com desconfiança para o SAAL (Bandeirinha, 2007;
Cerezales, 2003; Pinto, 2013; Ferreira, 1987). Foi neste contexto que, em 1976, o SAAL sofreu diversas alterações com o objectivo prático de revogar o Serviço. ${ }^{3}$ Em resposta, o Conselho Nacional do SAAL (CNS) apressou-se a elaborar um "livro branco", que indicava que até Outubro de 1976 foram registados 246 pedidos de intervenção em todo o país, tendo sido iniciadas 170 operações com um potencial de abranger 41665 famílias. Contudo, os números das concretizações eram mais modestos, indicando-se até à mesma data a construção de 2259 fogos e estando prevista a edificação a curto prazo de mais 6000 habitações (CNS, 1976).

\section{A Constituição da República Portuguesa}

Numa clara assunção progressista, a Constituição da República Portuguesa (CRP) consagra o direito à habitação, no Art. $65 .^{\circ}$, referindo-se no primeiro ponto deste artigo: "1. Todos têm direito, para si e para a sua família, a uma habitação de dimensão adequada, em condições de higiene e conforto e que preserve a intimidade pessoal e a privacidade familiar."

Não obstante pequenas alterações nas décadas seguintes, o Art. $65 .^{\circ}$ manteve o seu sentido programático para incentivar a administração pública a assegurar o direito à habitação, mas não de forma necessariamente vinculativa, como ocorre noutros direitos constitucionais. No âmbito da revisão constitucional de 2001 , o Art. $65 .^{\circ}$ foi alterado para "Habitação e Urbanismo" e o seu conteúdo reflecte actualmente uma redacção que incorpora questões como a habitação, o urbanismo e o ordenamento do território. Actualmente, a questão do acesso à habitação está também incluída no Art. 72. ${ }^{\circ}$ ("Terceira Idade") 4 e no Art. 70. ("Juventude") 5 .

O Art. $65 .^{\circ}$ foi, logo em 1976, vanguardista ao consagrar o direito à habitação, o que está longe de ocorrer em todas as constituições europeias (Farha, 2017), mesmo nos países que mais investiram no Estado Social na segunda metade do século $X X$. Paralelamente, o progressismo do Art. $65 .^{\circ}$ pode também ser aferido ao assumir preocupações com a rede de transportes e de equipamentos sociais, assim como a necessidade de apoiar especificamente as "iniciativas das comunidades locais" (i. e., associações e comissões de moradores), a "autoconstrução", as "cooperativas de habitação" e, também, "políticas tendentes a estabelecer um sistema de renda compatível com o rendimento familiar".

A promoção indirecta: cooperativas e iniciativa privada

As cooperativas de habitação

Em Portugal a acção das cooperativas de habitação era possível desde Oitocentos, ao abrigo da 
Lei Basilar do Cooperativismo de 1867. Contudo, a actividade destas entidades foi sempre incipiente, ainda no século XIX, devido à inexperiência com o modelo cooperativo, e, mais tarde, durante a ditadura, as cooperativas de habitação estavam dependentes da capacidade de autofinanciamento, funcionando essencialmente como Caixas de Crédito Imobiliário, ao que acrescia a desconfiança política do movimento cooperativo (Ferreira, 1987; Matos, 1994; CET, 1994; Pedrosa, 2018; Antunes, 2018).

Foi após a revolução que foram criadas as condições para fomentar a acção das cooperativas de habitação (FFH, 1979). Em Dezembro de 1974, foi publicado o Regime Jurídico da Cooperação Habitacional ${ }^{6}$, que regulava a constituição das cooperativas de habitação, e um outro diploma que especificava os apoios para as denominadas Cooperativas de Habitação Económica $(\mathrm{CHE})^{7}$, ou seja, as cooperativas que tivessem por objectivo construir ou adquirir habitações de interesse social.

Não obstante os dois diplomas publicados em Dezembro de 1974 - cujo objectivo foi fomentar a actividade das cooperativas de habitação e de modernização jurídica conforme a realidade internacional -, a acção destas entidades manteve-se incipiente, em grande medida devido à indefinição dos apoios financeiros (Ferreira, 1987). Embora existisse legislação que regulasse o funcionamento das $\mathrm{CHE}$, o esquema de apoio financeiro apenas foi definido em 1977, num sistema análogo ao regime de crédito geral, o que desagradou às cooperativas e impediu que a actividade se desenvolvesse ( $F F H$, 1979). ${ }^{8}$ Esta situação apenas foi ultrapassada no ano seguinte, depois de ter sido promulgado um novo diploma que instituiu um esquema de financiamento mais vantajoso para as $\mathrm{CHE} .{ }^{9}$ No preâmbulo deste novo diploma, o legislador fazia questão de sublinhar a importância das cooperativas de habitação e explicava em que medida estas podiam substituir a função do Estado, sobretudo no que dizia respeito ao acesso a casa própria por parte de famílias da classe média. Embora o esquema de apoio financeiro tenha sido definido de forma satisfatória em 1978, este período coincidiu com a primeira intervenção do Fundo Monetário Internacional (FMI), o que afectou as verbas públicas que podiam ser alocadas. Desta forma, a actividade das cooperativas de habitação manteve-se com sérias dificuldades.

Na década de 1980 surgiram mais alterações legislativas importantes, como o Código Cooperativo $^{10}$, que pretendia reformar e regular a acção de todo o movimento cooperativo. O Código Cooperativo integrava as cooperativas de habitação no ramo das "cooperativas de construção e habitação", que estava dependente de legislação própria a publicar. No preâmbulo do Código Cooperativo era indicado que existiam, em 1974, cerca de 40 cooperativas de habitação activas (4,2\% do universo cooperati- vista), número que subiu para 258 em 1979 (7,2\% do universo cooperativista).

Em 1982 surge a legislação própria das "cooperativas de construção e habitação"11 - conforme era exigido no Código Cooperativo de 1980 -, revogando os dois diplomas publicados em 1974. Nos anos seguintes ocorreram diversas alterações legislativas, sobretudo nos modelos de financiamento, adaptações às alterações institucionais, direccionamento dos financiamentos para a aquisição de casa própria e condicionamento dos financiamentos ao cumprimento das limitações estabelecidas para a "habitação social"12 e, posteriormente, "habitação a custos controlados"13.

No que respeita à experiência das cooperativas, salienta-se que entre 1974 e 1979 existiu uma explosão significativa na formação de cooperativas de habitação (Coelho, 2013; Pedrosa, 2018). Apesar do forte crescimento, o número de fogos construídos manteve-se reduzido até 1980 , devido à tardia consolidação dos apoios financeiros e ao pedido de ajuda externa. De acordo com dados do $\mathrm{INE}^{14}$, entre 1974 e 1980 foram construídos 1512 fogos, numa média de 252 fogos anuais, o que representava, para o mesmo período analisado, cerca de $5 \%$ dos fogos construídos em território nacional. Nos anos seguintes, as alterações legislativas que estabilizaram os apoios permitiram que, entre 1985 e 1995, se consolidasse o momento mais produtivo da história das cooperativas de habitação no nosso país. Entre 1980 e 1990 foram construídos 18856 fogos, numa média anual de 1886 habitações. Nos primeiros anos da década de 1990, o número anual de fogos construídos era superior a 3000 fogos por ano, tendo ultrapassado, em 1993, os 4000 fogos anuais, o que representava cerca de $6 \%$ dos fogos construídos.

Estudos concretizados no início da década de 1990 pela Federação Nacional de Cooperativas de Habitação Económica (FENACHE) apontam para a existência de 395 cooperativas de habitação (das quais 200 deviam estar activas), constituídas por 60000 cooperadores (FENACHE, 1991, 1992). Os levantamentos e estudos concretizados pelo Centro de Estudos do Cooperativismo Habitacional, da FENACHE, indicam que, entre 1974 e 1990, foram construídos cerca de 30000 fogos por cooperativas de habitação, número que ultrapassa em cerca de 10000 fogos os dados do INE para o mesmo período (FENACHE, 1991).

Depois da explosão da construção de fogos por cooperativas de habitação entre 1985 e 1995, a actividade voltou a diminuir, até regressar a valores residuais no século XXI. Do ponto de vista espacial, as cooperativas de habitação construíram habitações em todos os distritos, com especial incidência nas Áreas Metropolitanas de Lisboa e do Porto (Pedrosa, 2018). Importa salientar que mesmo no período de 
maior actividade as cooperativas de habitação se debateram com vários obstáculos, destacando-se o problema fundiário, situação que era resolvida, em parte, pela disponibilização de solos municipais em direito de superfície. Neste propósito, a articulação com os municípios foi essencial para alavancar a actividade das cooperativas de habitação, que, de outra forma, teriam dificuldades para adquirir os terrenos necessários para a construção de empreendimentos habitacionais de interesse social (Matos, 1994).

Ainda na década de 1980, estudos que analisaram a actividade das cooperativas de habitação denunciavam que estas entidades estavam a focalizar a construção para a classe média (FFH, 1980; LNEC, 1989). Tal como aponta Matos (1994), no decorrer da década de 1980 a classe social que recorria às cooperativas de habitação foi alterada, desvirtuando-se o ideal cooperativista e transformando-se estas entidades em "cooperativas-empresas".

A iniciativa privada apoiada pelo Estado

Em Novembro de 1974 foi criado o programa Contratos de Desenvolvimento para Habitação $(\mathrm{CDH}) .{ }^{15}$ Esta medida era, na verdade, uma reforma da política de casas de renda limitada, que existia desde $1947^{16}$ e que tinha sido alvo de várias alterações em $1973^{17}$ (Antunes, 2018). A política $\mathrm{CDH}$ tinha como objectivo despertar a indústria da construção para a promoção de casas de interesse social (Ferreira, 1987). Para tal, foram estipulados vários benefícios, como apoio técnico do $\mathrm{FFH}$, financiamento em condições favoráveis, isenções fiscais, garantia de compra das habitações pela administração pública, acesso a terrenos em condições vantajosas, entre outros. A política $\mathrm{CDH}$ pretendia aumentar a oferta de habitações para a classe média urbana, num esquema que reduzia os custos de construção e assegurava, à partida, o lucro das empresas privadas e a diminuição de risco empresarial. Este conjunto de benefícios não foi suficientemente aliciante para as construtoras, sendo que, de acordo com dados do INE, o número de habitações construídas foi residual.

Para alterar esta conjuntura, sucederam-se inúmeras alterações legislativas ao programa $\mathrm{CDH}$. Entre 1976 e 1985, contam-se cinco grandes alterações, que alteraram substancialmente a filosofia inicial do programa, e que no sentido geral tinham como objectivo descentralizar a medida e reduzir o risco empresarial (Ferreira, 1987; Antunes, 2018). Em 1985, o programa CDH foi alvo de uma ampla reforma ${ }^{18}$ que tinha como propósito relacionar o programa com as orientações referentes às Habitações a Custos Controlados (HCC). Estas alterações tiveram como objectivo reduzir a intervenção do Estado, desburocratizar e flexibilizar o processo administrativo e privilegiar a aquisição de casa própria. Depois de uma nova alteração em 1989, o programa consolidou-se em 1993, na sua última redacção. ${ }^{19}$ Embora em moldes jurídicos ligeiramente diferentes, também as cooperativas de habitação estão incluídas na promoção de HCC.

De acordo com o INE ${ }^{20}$, o número de habitações construídas pela iniciativa privada ao abrigo desta política foi sempre diminuta, contando-se, entre 1974 e 1992, a construção de 17807 fogos em território nacional, a maioria nos distritos do Porto (14\%), Setúbal (11\%) e Lisboa (10\%). No século XXI a construção diminuiu para valores residuais.

A promoção directa: construção do parque habitacional público

Na transição entre as décadas de 1970 e 1980, os projectos mais significativos de promoção directa estavam relacionados com os Planos Integrados do $\mathrm{FFH}$, que vinham ainda da ditadura e atravessavam dificuldades no seu desenvolvimento (Ferreira, 1987). No início da década de 1980 , a promoção de habitação pública ficou ainda mais indefinida quando, em 1982, o FFH foi extinto, tendo sido substituído pelo efémero Fundo de Apoio ao Investimento para Habitação, substituído dois anos depois pelo Instituto Nacional de Habitação (INH), ao qual se juntou, em 1987, o Instituto de Gestão e Alienação do Património Habitacional do Estado (IGAPHE). Além destas alterações institucionais, foi ainda neste período que o legislador definiu o conceito de "habitação social"21 e estabeleceu os parâmetros mínimos e máximos para a construção deste tipo de habitações pela iniciativa pública, privada e cooperativa. Anos mais tarde, o legislador substituiu conceito de "habitação social" por "habitações a custos controlados"22, o que se manteve, posteriormente, em $1997^{23}$.

No meio destas alterações legais e institucionais, foram promulgados programas que definiam condições especiais de acesso ao crédito para os municípios, com o objectivo de estimular a promoção directa de habitações e a conservação do parque público existente, tal como ocorreu em $1983^{24}$ e $1985^{25}$. Contudo, os reduzidos apoios financeiros e a instabilidade institucional - que apenas foi estabilizada com a criação do INH e do IGAPHE - fizeram com que os programas referidos não tivessem a aceitação e a colaboração necessária por parte do poder local (Antunes, 2018).

A primeira grande alteração a este cenário ocorreu pela promulgação do Decreto-Lei n. ${ }^{\circ}$ 226/87, de 6 de Junho, que estabeleceu de forma concreta o regime de cooperação entre a administração central e local para a celebração de protocolos para a construção de habitação social para arrendamento. Desta forma, foram esclarecidas as responsabilidades e as competências dos poderes central e local e, simultaneamente, foi definido um modelo de apoio 
para todo o território nacional, em que os municípios interessados poderiam candidatar-se e, posteriormente, aceder a financiamento a fundo perdido, do IGAPHE, e empréstimos favoráveis, do INH.

Ao abrigo destes diplomas foram contratualizados alguns programas de realojamento, como foi o caso do município de Lisboa, que, em 1987, estabeleceu o Programa de Intervenção a Médio Prazo, que previa a construção de 9698 fogos para realojamento de famílias residentes em bairros de habitações precárias existentes na capital $(\mathrm{DCH}$, 1990).

No início da década de 1990, percebeu-se que apenas uma política alargada de promoção pública poderia resolver o problema dos bairros de habitações precárias existentes nas duas áreas metropolitanas. Note-se que, conforme a Tabela 1, existiam em 1981 cerca de 46000 alojamentos familiares não clássicos em Portugal.

Tabela $1 \triangleright$ Alojamentos familiares não clássicos em Portugal, entre 1981 e 2011. INE

\begin{tabular}{c|c|c|c}
\hline $\mathbf{1 9 8 1}$ & $\mathbf{1 9 9 1}$ & $\mathbf{2 0 0 1}$ & $\mathbf{2 0 1 1}$ \\
\hline 46391 & 27642 & 27182 & 6612 \\
\hline
\end{tabular}

Foi neste contexto que, em 1993, foi publicado o Programa Especial de Realojamento (PER), que previa a concessão de apoio financeiro aos municípios para a construção ou aquisição de habitações, destinadas ao realojamento de agregados familiares residentes em alojamentos precários nas Áreas Metropolitanas de Lisboa e do Porto. ${ }^{26}$ Os mecanismos financeiros do PER eram, na realidade, relativamente semeIhantes aos definidos pelo Decreto-Lei n. ${ }^{\circ} 226 / 87$, mas, em meados da década de 1990, juntavam-se a estes apoios financeiros e institucionais o desígnio nacional de "erradicação" dos chamados "bairros de barracas".

Nos anos seguintes, com vista ao desenvolvimento do PER, foram celebrados contratos-programa entre municípios, o INH e o IGAPHE. O desenvolvimento do PER foi bastante díspar de concelho para concelho. Enquanto municípios como Mafra, Moita, Montijo, Sesimbra, Gondomar, Porto e Valongo cumpriram a construção da totalidade dos fogos protocolados, outros municípios não foram tão expeditos e diligentes, como foi o caso da Amadora $(45 \%)$, Barreiro (41\%), Odivelas (42\%), Palmela (44\%) e Seixal (45\%). No total, foram protocolados 48416 fogos e construídos 34759 (Figura 1). Apesar de o PER se consubstanciar como um programa abrangente para as duas áreas metropolitanas, o município de Lisboa dominou com 11129 fogos protocolados, seguindo-se os concelhos da Amadora (5419) e de Matosinhos (3982).

Embora não seja uma discussão que se pretenda densificar no presente trabalho, os bairros construí- dos no âmbito do PER foram alvo de grande debate técnico, político e académico ainda no seu início (Guerra, 1994, 1999; Freitas, 1994, 1998; Pinto 1994), assim como mais recentemente (Cachado, 2013; Serpa et al., 2018), com vários alertas para a excessiva concentração e homogeneidade social dos bairros construídos, assim como para a escassez de espaços públicos de qualidade, de equipamentos colectivos, de rede de transporte adequada, apoio social à população, entre muitos outros.

Em 2004, surgiu o PROHABITA ${ }^{27}$ que, à semeIhança do antigo Decreto-Lei n. ${ }^{\circ} 226 / 87$ (revogado pelo PROHABITA), era concretizado mediante a celebração de protocolos entre os municípios e o INH. Desta forma, ao contrário do que ocorreu com o PER, o PROHABITA regulava a concessão de financiamento para a resolução de situações de carência habitacional para todo o território nacional. Este programa foi ainda importante para modificar a forma como as operações de realojamento eram traçadas, ao privilegiar-se acções de reabilitação de edifícios em detrimento da construção nova e também ao melhorar a eficiência energética do edificado social (Antunes, 2018; Xerez, Rodrigues \& Cardoso, 2018).

Pese embora a existência dos programas de promoção directa referidos, em 2011, segundo o INE, subsistiam em território nacional 6612 alojamentos familiares não clássicos, ou seja, construções precárias, abarracadas ou amovíveis (Tabela 1). Mais recentemente, no âmbito da Nova Geração de Políticas de Habitação, foram publicados o $1 .{ }^{\circ}$ Direito ${ }^{28}$ e o Porta de Entrada ${ }^{29}$, que substituíram o PROHABITA e funcionam como os novos mecanismos legais para a resolução dos problemas mais graves de habitação, esperando-se, nos próximos anos, os desenvolvimentos destes programas. Note-se, também, que no âmbito da preparação destas medidas, o IHRU elaborou o Levantamento nacional das necessidades de realojamento habitacional, apresentado em Fevereiro de 2018. No contexto deste levantamento, 120 concelhos não reportaram qualquer carência habitacional e 187 identificaram 25762 famílias a residir em "situações claramente insatisfatórias". Deste total, 19050 famílias residem nas $A M L$ e AMP, com clara predominância da $A M L$, na qual foram identificados 13828 agregados familiares, ou seja, mais de $50 \%$ do total (IHRU, 2015).

\section{A habitação social desde 1974: que percurso?}

Depois da revolução, o SAAL foi a primeira política de habitação social. O SAAL é ainda hoje apontado como uma das medidas habitacionais mais vanguardistas promulgadas no nosso país (Antunes, 2018), afirmando Vieira (1986) que o SAAL instigou o único instante de interesse internacional pela 
Figura $1 \downarrow$ Número de fogos construídos, por concelho, no âmbito do Programa Especial de Realojamento

Programa

Especial de Realojamento

Número de fogos construídos

Espinho

Gondomar

Maia

Matosinhos

Porto

Póvoa de Varzim

Valongo

Vila do Conde

Vila Nova de Gaia

10000

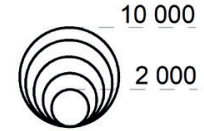

Alcochete

Almada

Amadora

Azambuja

Barreiro

Cascais

Lisboa

Loure

Mafra

Moita

Montijo

Odivelas

Oeiras

Palmela

Seixal

Sesimbra

Setúbal

Sintra

Vila Franca de Xira

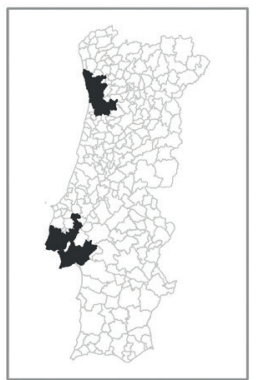

Fonte: Elaboração própria
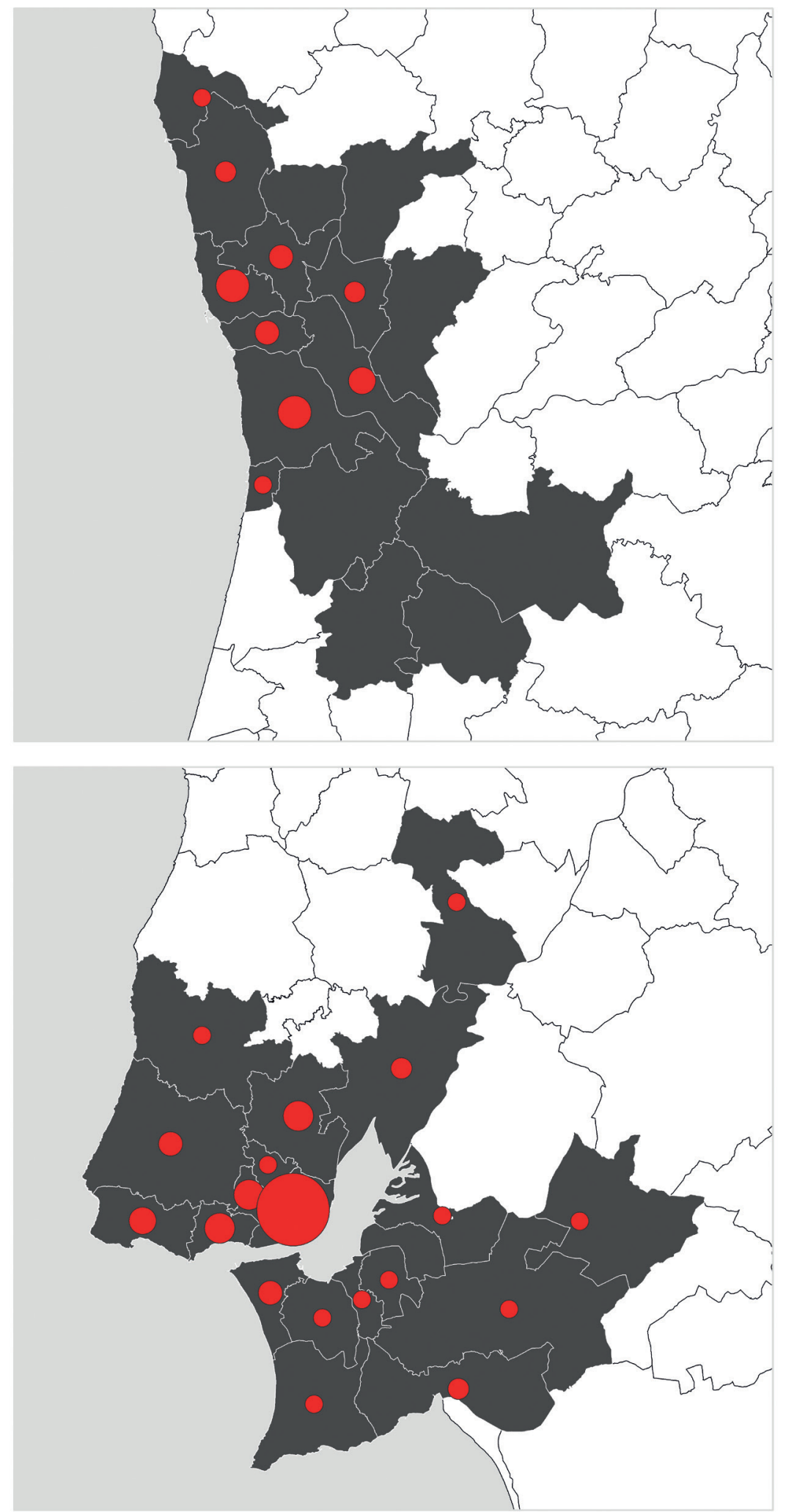
Arquitectura Portuguesa, e Bandeirinha (2007) que os bairros construídos ao abrigo do SAAL representam a arquitectura do 25 de Abril. Apesar dos elogios metodológicos e conceptuais que foram admitidos nas décadas seguintes, o SAAL teve uma evolução conturbada e acabou por ser paralisado ainda em 1976, o que afectou a construção e a finalização de vários projectos alinhavados.

Por sua vez, a CRP foi fundamental ao consagrar o direito à habitação, no espírito dos direitos defendidos na Declaração Universal dos Direitos Humanos. Contudo, o texto constitucional excessivamente programático não contribuiu para clarificar como e quando o Estado português deve actuar (Antunes, 2018). Esse papel estratégico e programático está, na verdade, reservado para as Leis de Bases, como as que foram criadas para outros direitos económicos, sociais e culturais consagrados na CRP, sem que, no entanto, o mesmo ocorresse para o direito à habitação.

No que se refere à promoção indirecta nos últimos 45 anos, destinada a cooperativas de habitação, iniciativa privada e entidades assistencialistas, vale a pena sublinhar que a construção de habitações com apoio da administração pública foi sempre um nicho de mercado, não obstante as várias alterações legislativas que tinham como objectivo tornar os programas mais atractivos. Importa também notar que as cooperativas demonstraram maior interesse e aptidão para a construção de habitações de interesse social (LNEC, 1989), embora o período mais profícuo tenha ficado reduzido a um espaço de tempo limitado, entre 1985 e 2000, o que coincidiu com o momento em que o mercado privado construiu mais habitações na história do nosso país (Mateus, 2015).

Acresce, ainda, que as habitações construídas ao abrigo de programas de promoção indirecta se destinaram fundamentalmente à classe média solvente, com capacidade para aceder ao crédito à habitação. Significa isto que as famílias destinatárias destes programas não foram necessariamente as mais carenciadas, mas, sim, a classe média em ascensão e com capacidade para aceder a crédito bancário para a aquisição de casa própria. Este fenómeno fez com que poucas cooperativas de habitação ou empresas privadas tenham permanecido proprietárias das habitações construídas com apoios públicos. Pelo contrário, a quase totalidade desse parque habitacional foi vendido após a construção, pelo que hoje a habitação social portuguesa é esmagadoramente de domínio público.

No que respeita à promoção directa, o PER tornou-se o programa mais importante e marcante da história da habitação portuguesa. No contexto da entrada de Portugal na Comunidade Económica Europeia, o desenvolvimento do PER possibilitou a construção de dezenas de milhares de habitações por todo o país, aumentando de forma significativa o parque habitacional municipal. A década de 1990 foi não só o momento mais importante para a construção de habitação pública, como o único da história da habitação portuguesa em que existiu um claro desígnio nacional de erradicar situações chocantes de indignidade humana.

Actualmente, o parque de habitação pública corresponde a 118000 fogos (2\% no parque habitacional nacional), propriedade de municípios, regiões autónomas e administração central, que proporcionam uma habitação a cerca de 113000 agregados familiares, englobando aproximadamente 270000 indivíduos (2,5\% da população portuguesa).

Como vimos anteriormente, no nosso país a habitação social é quase na totalidade propriedade pública, sendo reduzidas as entidades privadas, cooperativas ou assistencialistas que não alienaram em definitivo as habitações construídas com apoios. Paralelamente, o parque de habitação social que subsiste foi construído no contexto específico de programas de realojamento, pelo que existe uma oferta muito residual de habitação pública, cooperativa ou privada destinada a promover o acesso à habitação a famílias da classe média com dificuldades para garantir uma habitação no mercado livre.

De acordo com um estudo apresentado em $2015^{30}$ sobre as dotações do Orçamento do Estado executadas no período 1987-2011, foi reconhecido que dos 9,6 mil milhões de euros investidos em políticas de habitação, 73,3\% foram destinados para apoios à pessoa, nomeadamente para bonificações de juros no crédito à habitação, sendo que apenas $16,1 \%$ foram aplicados em programas de promoção directa e $0,1 \%$ em programas de promoção indirecta. ${ }^{31}$ Tendo sido este o momento mais importante de construção habitacional no nosso país, pode-se concluir que nos últimos 45 anos a "estratégia" habitacional se consubstanciou na bonificação de juros no crédito à habitação, que aglutinou o esforço financeiro e colocou em segundo plano as restantes opções, como a promoção indirecta ou a promoção directa de habitação social.

Conforme analisado, o desenvolvimento das políticas de habitação social em Portugal foi casuístico, sem continuidade, sistematização temporal nem estratégia a médio e a longo prazo. Actualmente, subsistem graves problemas de acesso a habitação condigna. Tal é comprovado nos dados do INE, de 2011, que indicam a existência de 6612 alojamentos familiares não clássicos, ou no levantamento promovido pelo IHRU, em 2018, que identificou 25762 famílias a residir em situações insatisfatórias em território nacional. Note-se que algumas destas ocorrências se traduzem, ainda, na subsistência de bairros de habitações precárias, com alojamentos construídos com materiais módicos, sem electricidade, água canalizada, saneamento básico ou ilu- 
minação pública. Fazendo a democracia portuguesa 45 anos em 2019, restará saber se, quando fizer meio século, ainda tolerará a existência de situações habitacionais que violam os direitos humanos mais elementares.

\section{Notas}

1 Para este trabalho foi analisado o conteúdo directo de cerca de 30 diplomas legislativos, todos referidos ao longo do texto, assim como de várias dezenas de portarias e diplomas de alteração.

2 Despacho conjunto dos Ministérios da Administração Interna e do Equipamento Social e do Ambiente, datado de 31 de Julho e publicado a 6 de Agosto de 1974.

${ }^{3}$ Despacho de 28 de Outubro de 1976.

${ }^{4}$ Revisão constitucional de 1982.

${ }^{5}$ Revisão constitucional de 2001.

${ }^{6}$ Decreto-Lei n. ${ }^{\circ}$ 730/74, de 20 de Dezembro

7 Decreto-Lei n. ${ }^{\circ}$ 737-A/74, de 23 de Dezembro.

8 Decreto-Lei n. ${ }^{\circ}$ 515/77, de 14 de Dezembro.

${ }^{9}$ Decreto-Lei n. ${ }^{\circ}$ 268/78, de 31 de Agosto.

10 Decreto-Lei n. ${ }^{\circ} 454 / 80$, de 9 de Outubro; alterado, entretanto, em 1996 e em 2015.

${ }_{11}$ Decreto-Lei n. ${ }^{\circ} 218 / 82$, de 2 de Junho.

12 Portaria n. ${ }^{\circ}$ 580/83, de 17 de Maio.

${ }^{13}$ Portaria n. ${ }^{\circ} 828 / 88$, de 29 de Dezembro.

${ }^{14}$ Estatística Industriais - Estatísticas da Construção e da Habitação.

15 Decreto-Lei n. ${ }^{\circ} 663 / 74$, de 26 de Novembro.

16 Decreto-Lei n. ${ }^{\circ} 36$ 212, de 7 de Abril 1947.

17 Decreto-Lei n. ${ }^{\circ}$ 608/73, de 14 de Novembro.

${ }^{18}$ Decreto-Lei n. ${ }^{\circ} 236 / 85$, de 5 de Julho.

19 Decreto-Lei n. ${ }^{\circ}$ 165/93, de 7 de Maio.

${ }^{20}$ Estatística Industriais - Estatísticas da Construção e da Habitação.

21 Portaria n. ${ }^{\circ}$ 580/83, de 17 de Maio.

22 Portaria n. ${ }^{\circ} 828 / 88$, de 29 de Dezembro.

23 Portaria n. ${ }^{\circ} 500 / 97$, de 21 de Julho.

24 Decreto-Lei n. ${ }^{\circ} 220 / 83$, de 26 de Maio.

25 Decreto-Lei n. ${ }^{\circ} 110 / 85$, de 17 de Abril.

${ }^{26}$ Decreto-Lei n. ${ }^{\circ}$ 163/93, de 7 de Maio

27 Decreto-Lei n. ${ }^{\circ}$ 135/2004, de 3 de Junho.

${ }^{28}$ Decreto-Lei n. ${ }^{\circ} 37 / 2018$, de 4 de Junho.

29 Decreto-Lei n. ${ }^{\circ}$ 29/2018, de 4 de Maio.

30 Resolução do Conselho de Ministros n. ${ }^{\circ}$ 48/2015.

${ }^{31} \mathrm{O}$ remanescente foi aplicado em apoios ao arrendamento, reabilitação e segurança social.

\section{Bibliografia}

Acciaiuoli, M. (2015). Casas com escritos - uma história da habitação em Lisboa. Lisboa: Bizâncio.

Agarez, R. (Coord.). (2018). Habitação - cem anos de políticas públicas em Portugal 1918-2018. Lisboa: Instituto da Habitação e da Reabilitação Urbana.

Allen, J., Barlow, J. Leal, J. Maloutas, T., \& Padovani, L. (2004). Housing \& welfare in southern Europe. Oxford: Blackwell Publishing.

Antunes, G. (2018). Políticas de habitação - 200 anos. Lisboa: Caleidoscópio e Câmara Municipal de Lisboa.

Balchin, P. (Ed.). (1996). Housing policy in Europe. Londres: Routledge.

Bandeirinha, J. (2007). O processo SAAL e a Arquitectura no 25 de Abril de 1974. Coimbra: Imprensa da Universidade de Coimbra.

Baptista, L. (1999). Cidade e Habitação Social: o Estado Novo e o Programa de Casas Económicas em Lisboa. Oeiras: Celta.

Baptista, L. (2001). Cidade e Políticas Sociais de Habitação - Armadilhas Conceptuais e Metodológicas. Cidades Comunidades e Territórios, 3, 71-81.

Bargelli, E., \& Heitkamp, T. (2018). New Developments in Southern European Housing. Pisa: Pisa University Press.

Cachado, R. A. (2013). O Programa Especial de Realojamento - ambiente histórico, político e social. Análise Social, 206(XLVIII), 135-152.

Cerezales, D. (2003). O poder caiu na rua - crise de Estado e acções colectivas na revolução portuguesa 1974-1975. Lisboa: Instituto de Ciências Sociais.

CET. (1994). Cooperativas de habitação de Lisboa situação e perspectivas. Lisboa: Observatório da Habitação.

CNS. (1976). Livro branco do SAAL. Vila Nova de Gaia: Conselho Nacional do SAAL.

Coelho, A. B., \& Coelho, P. R. (2009). Habitação de interesse social em Portugal 1988-2005. Lisboa: Livros Horizonte.

Coelho, A. B. (2006). 1984 - 2004, 20 anos a promover a construção de habitação social. Lisboa: Instituto da Habitação e da Reabilitação Urbana.

Coelho, A. B. (2013). Os anos dourados dos conjuntos cooperativos de habitação económica (1974-1984). In. N. Portas (coord.). Habitação para o maior número, Portugal, os anos de 1950-1980. Lisboa: Instituto da Habitação e da Reabilitação Urbana.

DCH. (1990). Boletim Departamento de Construção de Habitação n. ${ }^{\circ}$ 52. Lisboa: Departamento de Construção de Habitação / Câmara Municipal de Lisboa.

Decreto-Lei n. ${ }^{\circ} 36$ 212, de 7 de Abril. Diário do Governo n. ${ }^{\circ}$ 78/1947 - Série I. Lisboa: Ministérios das Finanças e das Obras Públicas

Decreto-Lei n. ${ }^{\circ} 608 / 73$ de 14 de Novembro. Diário do Governo n.o 266/1973, 1. ${ }^{\circ}$ Suplemento - Série I. 
Lisboa: Ministério das Obras Públicas - Secretaria de Estado do Urbanismo e Habitação

Decreto-Lei n. ${ }^{\circ}$ 110/85 de 17 de Abril. Diário da República n. ${ }^{\circ}$ 89/1985 - Série I. Lisboa: Ministério do Equipamento Social

Decreto-Lei n.o 135/2004 de 3 de Junho. Diário da República n. ${ }^{\circ}$ 130/2004 -- Série I-A. Lisboa: Ministério das Obras Públicas, Transportes e Habitação

Decreto-Lei n. ${ }^{0}$ 163/93 de 7 de Maio. Diário da República n. ${ }^{0}$ 106/1993 - Série I-A. Lisboa: Ministério das Obras Públicas, Transportes e Comunicações

Decreto-Lei n. ${ }^{\circ}$ 165/93 de 7 de Maio. Diário da República n.o 106/1993 - Série I. Lisboa: Ministério das Obras Públicas, Transportes e Comunicações

Decreto-Lei n. ${ }^{\circ}$ 218/82 de 2 de Junho. Diário da República n. ${ }^{\circ}$ 125/1982 - Série I. Lisboa: Presidência do Conselho de Ministros

Decreto-Lei n. ${ }^{2} 220 / 83$ de 26 de Maio. Diário da República n. ${ }^{\circ}$ 121/1983 - Série I. Lisboa: Ministérios das Finanças e do Plano e da Habitação, Obras Públicas e Transportes

Decreto-Lei n. ${ }^{\circ}$ 236/85 de 5 de Julho. Diário da República n.o 152/1985 - Série I. Lisboa: Ministério do Equipamento Social

Decreto-Lei n.o 268/78 de 31 de Agosto. Diário da República n.o 287/1977, Série I. Lisboa: Ministério da Habitação e Obras Públicas - Gabinete do Ministro

Decreto-Lei n. ${ }^{\circ}$ 29/2018 de 4 de Maio. Diário da República n. ${ }^{\circ}$ 86/2018, Série I. Lisboa: Presidência do Conselho de Ministros

Decreto-Lei n. ${ }^{\circ}$ 37/2018 de 4 de Junho. Diário da República n.o 106/2018, Série I. Lisboa: Presidência do Conselho de Ministros

Decreto-Lei n. ${ }^{\circ}$ 454/80 de 9 de Outubo. Diário da República n.o 234/1980 - Série I. Lisboa: Presidência do Conselho de Ministros - Gabinete do Ministro Adjunto do Primeiro-Ministro

Decreto-Lei n. ${ }^{0}$ 515/77 de 14 de Dezembro. Diário da República n.o 287/1977 - Série I. Lisboa: Ministérios das Finanças e da Habitação, Urbanismo e Construção

Decreto-Lei n. ${ }^{\circ}$ 663/74 de 26 de Novembro. Diário do Governo n.o 275/1974 - Série I. Lisboa: Ministérios das Finanças e do Equipamento Social e do Ambiente

Decreto-Lei n. 0 730/74 de 20 de Dezembro. Diário do Governo n. ${ }^{\circ}$ 296/1974 - Série I. Lisboa: Ministérios da Justiça e do Equipamento Social e do Ambiente

Decreto-Lei n. 0 737-A/74 de 23 de Dezembro. Diário do Governo n.o 298/1974 - Série I. Lisboa: Ministério do Equipamento Social e do Ambiente - Secretaria de Estado da Habitação e Urbanismo

Despacho de 28 de Outubro. Diário da República n.o 253/1976 - Série I. Lisboa: Presidência do ConseIho de Ministros - Secretaria de Estado da Comunicação Social - Gabinete do Secretário de Estado

Despacho de 6 de Agosto. Diário do Governo n. 0 182/1974 - Série I. Lisboa: Ministérios da Administração Interna e do Equipamento Social e do Ambiente
Dias, J. (1994). Tendências das políticas europeias quanto aos modelos de habitação social. Sociedade e Território, 20, 91-100.

Farha, L. (2017). Report of the Special Rapporteur on adequate housing as a component of the right to an adequate standard of living, and on the right to non-discrimination in this context, on her mission to Portugal. Nova Iorque: Nações Unidas.

FENACHE (1991). As Cooperativas de Habitação e sua actividade - primeiros resultados de um levamento. Porto: Centro de Estudos do Cooperativismo Habitacional.

FENACHE (1992). Habitação cooperativa em Portugal 1974-1991. Lisboa: Federação Nacional de Cooperativas de Habitação Económica.

Ferreira, A. F. (1987). Por uma nova política de habitação. Lisboa: Edições Afrontamento.

Ferreira, A. F. (1993). Livro branco sobre a política da habitação em Portugal. Lisboa: Encontro Nacional da Habitação.

FFH. (1979). Cooperativas de habitação em Portugal. Lisboa: Ministério da Habitação e Obras Públicas - Secretaria de Estado da Habitação [relatório policopiado].

FFH. (1980). A gestão nas cooperativas de habitação. Lisboa: Fundo de Fomento da Habitação [relatório policopiado].

Freitas, M. J. (1994). Os paradoxos do realojamento. Sociedade e Território, 20, 26-34.

Freitas, M. J. (1998). Pensar os espaços domésticos em contextos de realojamento. Sociedade e Território, 25/26, 150-161.

Freitas, M. J. (2002). Aprendizagens num percurso de autonomias e poderes - o processo de realojamento em Cascais. Cidades. Comunidades $e$ Territórios, 4, 19-32.

Gros, M. C. (1994). Pequena História do Alojamento Social em Portugal. Sociedade e Território, 20, 80-90.

Guerra, I. (1994). As pessoas não são coisas que se ponham em gavetas. Sociedade e Território, 20, 11-16.

Guerra, I. (2011). As políticas de habitação em Portugal: à procura de novos caminhos. Cidades - Comunidades e Territórios, 22, 41-68.

Guerra, I. (Coord.). (1999). Diagnóstico sobre a Implementação do programa PER nos municípios das Áreas Metropolitanas de Lisboa e Porto. Lisboa: Instituto Nacional de Habitação.

Hughes, D., \& Lowe, S. (2000). Public sector housing law. Londres: Reed Elsevier.

IHRU. (2015). 1987-2011 - 25 anos de esforço do Orçamento do Estado com a habitação. Instituto da Habitação e da Reabilitação Urbana. Lisboa: IHRU.

Lei Constitucional n. ${ }^{\circ}$ 1/2001. Diário da República n. ${ }^{\circ}$ 286/2001 - Série I-A de 2001-12-12. Lisboa: Assembleia da República

Lei Constitucional n.0 1/82. Diário da República n.o 227/1982 - Série de 1982-09-30I. Lisboa: Assembleia da República 
LNEC. (1989). Análise dos empreendimentos apoiados pelo INH. Lisboa: Laboratório Nacional de Engenharia Civil [relatório policopiado].

Lowe, S. (2011). The housing debate. Bristol: University of Bristol.

Lund, B. (2016). Housing politics in the United Kingdom. Bristol: Policy Press University of Bristol.

Malpass, P., \& Murie, A. (1999). Housing policy and practice. Nova Iorque: Palgrave Macmillan.

Mateus. A. (Coord.). (2015). Três décadas de Portugal Europeu - balanço e perspectivas. Lisboa: Fundação Francisco Manuel dos Santos.

Matos, F. (1994). Habitação cooperativa no grande Porto. Revista da Faculdade de Letras - Geografia, X/XI, 19-38.

McCrone, G., \& Stephens, M. (2017). Housing policy in Britain and Europe. Routledge: Londres.

Mullins, D., \& Murie, A. (2006). Housing policy in the UK. Nova Iorque: Palgrave Macmillan.

Paiva, F. (1997). Estudo de caracterização das cooperativas de habitação em Portugal. In. As cooperativas de habitação em Portugal. Lisboa: Instituto António Sérgio.

Pedrosa, P. (2018). As cooperativas de habitação portuguesas: O jogo dos possíveis. In R. Agarez, (Coord.), Habitação - cem anos de políticas públicas em Portugal 1918-2018. Lisboa: Instituto da Habitação e da Reabilitação Urbana.

Pinto, P. (2008). Urban social movements and the transition to democracy in Portugal - 1974-1976. The Historical Journal, 51(4), 1025-1046.

Pinto, P. (2013). Lisbon rising: urban social movements in the portuguese revolution - 1974-75. Manchester: Manchester University Press.

Pinto, T. C. (1994). A apropriação do espaço em bairros sociais: o gosto pela casa e o desgosto pelo bairro. Sociedade e Território, 20, 36-43.

Portaria n. ${ }^{\circ}$ 500/97 de 21 de Julho. Diário da República n. 0 166/1997 - Série I-B. Lisboa: Ministério do Equipamento, do Planeamento e da Administração do Território

Portaria n. ${ }^{\circ}$ 580/83 de 17 de Maio. Diário da República n.o 113/1983 - Série I. Lisboa: Ministério da Habitação, Obras Públicas e Transportes

Portaria n. ${ }^{\circ}$ 580/83 de 17 de Maio. Diário da República n.o 113/1983 - Série I. Lisboa: Ministério da Habitação, Obras Públicas e Transportes
Portaria n. ${ }^{\circ}$ 828/88 de 29 de Dezembro. Diário da República n.o 300/1988 - Série I. Lisboa: Ministério das Obras Públicas, Transportes e Comunicações

Portaria n. 0 828/88 de 29 de Dezembro. Diário da República n.o 300/1988 - Série I. Lisboa: Ministério das Obras Públicas, Transportes e Comunicações

Portas, N. (Coord.) (2013). Habitação para o maior número, Portugal, os anos de 1950-1980. Lisboa: Instituto da Habitação e da Reabilitação Urbana.

Resolução do Conselho de Ministros n. 0 48/2015. Diário da República n.o 136/2015, Série I. Lisboa: Presidência do Conselho de Ministros

Santos, B. S. (2017). As bifurcações da ordem - revolução, cidade, campo e indignação. Coimbra: Almedina.

Serpa, F. (Coord). (2018). Habitação de promoção pública: da construção nova a reabilitação, uma leitura dos projectos. In R. Agarez (Coord.), Habitação - cem anos de políticas públicas em Portugal 1918-2018. Lisboa: Instituto da Habitação e da Reabilitação Urbana.

Serra, N., (2002). Estado, território e estratégias de habitação. Coimbra: Quarteto Editora.

Silva, C. N. (1994a). 1926-1974 Política urbana em Lisboa. Lisboa: Livros Horizonte.

Silva, C. N. (1994b). Mercado e políticas públicas em Portugal: a questão da habitação na primeira metade do século XX. Análise Social, XXIX, 655-676.

Silva, C. N. (1994c). Política e gestão municipal em Lisboa no século $X X$ : situação e perspectivas da investigação. Lisboa: Revista Penélope, 13, 163-173.

Silva, C. N. (1997). Política urbana em Lisboa: elementos para uma periodização. I Colóquio Temático, O município de Lisboa e a dinâmica urbana (séculos XVI-XIX), 293-306

Vieira, A. S. (1986). O 25 de Abril e a transformação da cidade. Revista Crítica de Ciências Sociais, 18, 19, 20, 37-40.

Xerez, R., Rodrigues, P., \& Cardoso, F. (2018). A política de habitação em Portugal de 2002 a 2017: Programas, políticas públicas implementadas e instituições envolvidas. In R. Agarez (Coord.), Habitação - cem anos de políticas públicas em Portugal 1918-2018. Lisboa: Instituto da Habitação e da Reabilitação Urbana.

Gonçalo Antunes (Gonçalo.antunes@fcsh.unl.pt) Centro Interdisciplinar de Ciências Sociais (CICS.NOVA), Faculdade de Ciências Sociais e Humanas (NOVA FCSH). Avenida de Berna, 26, 1069-061 Lisboa. 


\title{
UM LUGAR EM PRODUÇÃO: O CASO DA COVA DA MOURA
}

\section{A PLACE IN THE MAKING: THE CASE OF COVA DA MOURA}

\author{
Sílvia Jorge \\ Faculdade de Arquitetura da Universidade de Lisboa, GESTUAL-CIAUD \\ Júlia Carolino \\ Faculdade de Arquitetura da Universidade de Lisboa, GESTUAL-CIAUD
}

\begin{abstract}
Resumo
Resultantes da ocupação e construção sem licença em terrenos públicos e/ou privados, os bairros autoproduzidos, não reconhecidos legalmente pelo poder público, tendem a ser reduzidos às suas falhas e carências, espelhadas nas designações que lhes são geralmente atribuídas, como "bairros de barracas" ou "bairros precários". Por sua vez, este sentido negativo e pejorativo acaba por influenciar ou determinar a forma como técnicos e decisores políticos leem estes territórios, tendendo-se a preconizar a demolição do tecido urbano existente, distante dos parâmetros e da imagem de cidade hegemónicos. Tomando como caso de estudo o bairro da Cova da Moura, na Amadora, convocamos os conceitos de "lugar" e de "direito ao lugar" para explorar diferentes leituras e perceções sobre este território, cruzando duas perspetivas - uma mais antropológica e outra sócio-urbanística -, num diálogo entre as dinâmicas e aspirações locais e as políticas e instrumentos de intervenção propostos ao longo do tempo. Face à existência de uma realidade local plural e negociada, propõe-se um novo olhar sociopolítico sobre a mesma, inscrito na luta pelo direito ao lugar aqui em destaque.
\end{abstract}

Palavras-chave: produção do lugar; direito ao lugar; Cova da Moura

\section{Abstract}

Following the settlement and construction without permit on public and/or private land, self-produced neighbourhoods tend to be portrayed in ways that reduce them to their problems and are expressed through designations like "slums" or "precarious settlements". These negative designations play a role in the way professionals and decision makers make sense of these territories, favouring demolitions of the existing urban tissue as solutions for realities that fail to match the hegemonic image and parameters of the city. Taking bairro da Cova da Moura as a case study, we draw on the notions of "place" and "the right to place" to explore and relate different understanding and perceptions of that territory. We resource on anthropological and on socio-urban perspectives for looking through both the local dynamics and aspirations and the policies and tools for intervention proposed over the long term. Taking into account the existence of a plural and negotiated local reality, it is proposed a new socio-political perspective, inscribed on the fight for the right to place here in highlighted.

Keywords: production of place; right to the place; Cova da Moura

\section{Introdução}

São várias as noções a que se recorre para designar os territórios de ocupação e construção não reconhecidos legalmente pelo poder público, como a Cova da Moura, no município da Amadora, com mais de 40 anos de existência. Usadas geralmente com um sentido pejorativo, denominações como "bairros de barracas", "informais" ou "precários" têm vindo a informar grande parte das iniciativas públicas, como o Programa Especial de Realojamento, que visou "[a] erradicação das barracas, uma chaga ainda aberta 


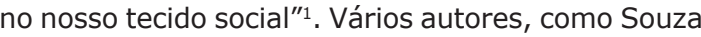
(2011) e Raposo (2012), destacam a necessidade de ampliar as dimensões de análise destes espaços autoproduzidos, integrando, além das suas faltas ou carências, os ganhos, as aspirações e as vivências de quem os habita e lhes dá identidade.

Tomando como caso de estudo o bairro da Cova da Moura (Figura 1), onde a estigmatização convive com uma identidade e dinâmica cultural que o distingue e projeta para além de si (Carolino, 2015), recorremos ao conceito de lugar para explorar e cruzar diferentes leituras e perceções sobre este território, ensaiando a sua possível adequação a uma visão mais complexa e próxima das dinâmicas que o constituem, no sentido de informar políticas públicas de intervenção mais participadas e inclusivas. Em face da persistente tensão entre soluções assentes na destruição do tecido autoproduzido e aquelas que, por sua vez, saem em defesa da sua qualificação (Raposo, 2009; Carolino, 2013), poderá fazer sentido um enfoque no direito ao lugar?

A noção de "lugar", intimamente ligada à de "espaço", convoca dimensões de coerência e identidade, implicando, necessariamente, um sujeito, um limite (fronteira) e a ideia de continuidade (Tuan, 1977; Hirsch, 1995; Casey, 1996). Numa aceção mais sociológica, o lugar define-se como um nexo de relação, história e identidade (Augé, 1992), descrito por Gupta e Ferguson como "um processo histórico partilhado que diferencia o mundo ao conectá-lo" (1997, p.46). Na linha da produção do espaço
(Lefebvre, 1991), Massey (2006) propõe a definição do lugar como um evento espácio-temporal, ou um nexo aleatório de trajetórias diversas que se cruzam entre si, perspetiva que converte todo o processo de constituição do sujeito e das fronteiras do lugar numa interrogação. É esta a abordagem adotada neste texto, ao procurar olhar o bairro da Cova da Moura como "um lugar" resultante da (inter)ação de um conjunto diversificado de atores e das narrativas em torno das quais se vai negociando a sua identidade e coerência socioespacial.

À luz deste caso específico, cruzam-se duas perspetivas: uma mais antropológica, reconstituindo a história da produção do lugar na perspetiva dos seus habitantes e das entidades através das quais se organizaram para assegurar o direito a permanecer no território que ocuparam e onde construíram as suas casas; outra mais sócio-urbanística, identificando a leitura de lugar subjacente às políticas e instrumentos de intervenção propostos, tendo em conta a constituição de uma arena específica de intervenção (Raposo et al., 2012; Raposo, 2009). Num primeiro momento, o texto foca precisamente a dimensão da produção do lugar, dialogando entre as iniciativas locais e as do poder público. Num segundo momento, analisa-se o processo de (re) afirmação do direito ao lugar em face da perspetiva de demolição do tecido autoproduzido. Por fim, num terceiro momento, centra-se o olhar na Nova Geração de Políticas de Habitação, nomeadamente no $1 .^{\circ}$ Direito - Programa de Apoio ao Acesso à Habitação²

Figura $1 \gg$ Bairro da Cova da Moura e sua envolvente

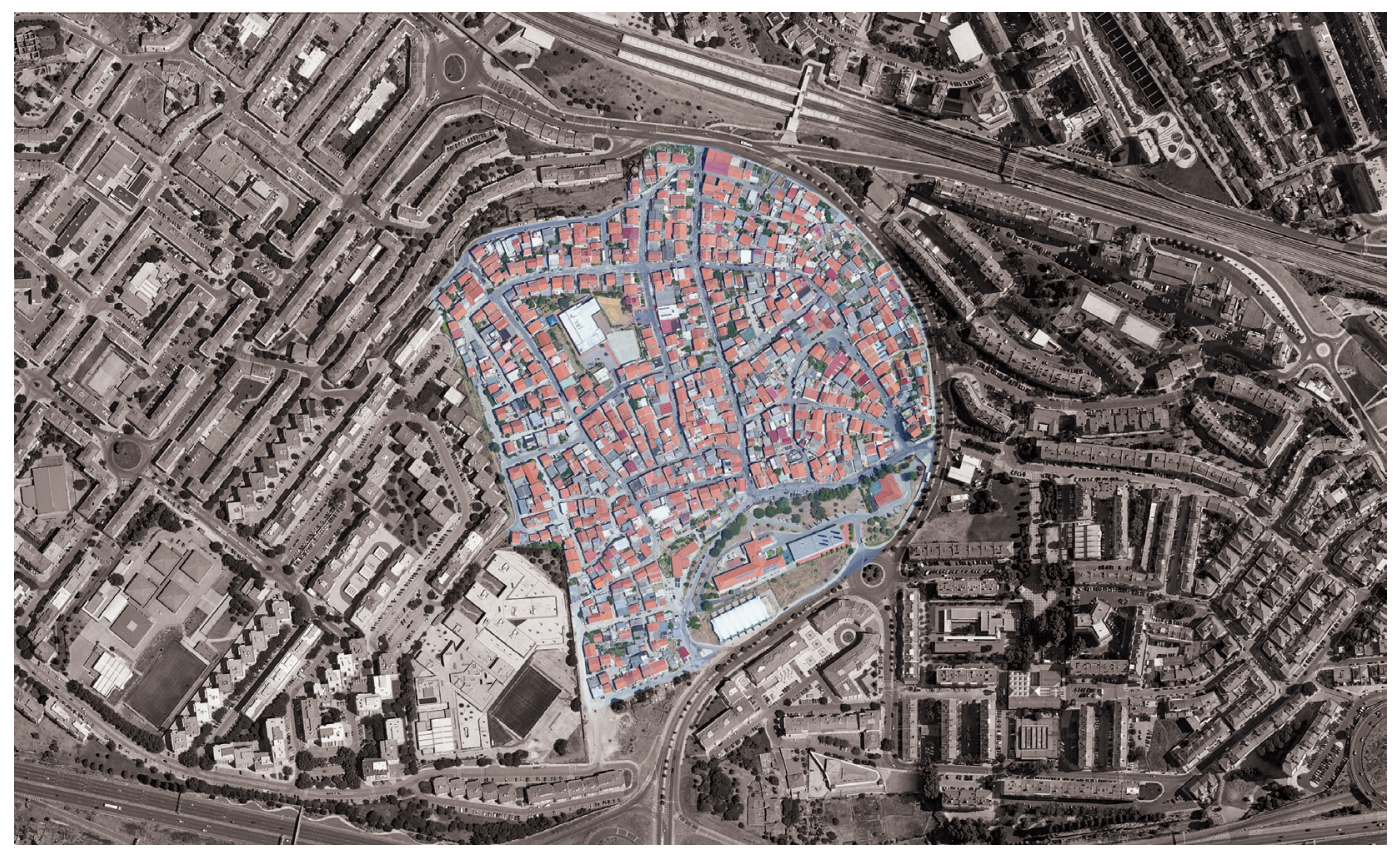

Fonte: Google Earth, 2019. Imagem trabalhada graficamente pelas autoras

Es Sociológico

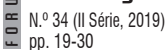


-, questionando até que ponto este representa ou pode vir a representar uma solução para o caso da Cova da Moura. Com esta análise cruzada, pretendemos contribuir para o conhecimento das relações, e possíveis sinergias, entre a intervenção pública e os movimentos e organizações locais comprometidos com o direito ao lugar.

Os dados aqui apresentados resultam de trabaIho de campo - apoiado na observação direta e em entrevistas qualitativas, semiestruturadas - realizado pelas autoras entre 2011 e 2018, no âmbito do apoio técnico prestado à Comissão de Bairro da Cova da Moura pelo Grupo de Estudos Sócio-Territoriais, Urbanos e de Ação Local, do Centro de Investigação em Arquitetura, Urbanismo e Design da Faculdade de Arquitetura da Universidade de Lisboa (GESTUAL/ CIAUD-FAUL), bem como da pesquisa etnográfica realizada por uma das autoras entre 2012 e 2016.

\section{A produção do lugar}

Situado nos interstícios da cidade em expansão, o território onde se localiza o bairro da Cova da Moura entrou numa fase inédita de transformação quando, na década de 50, alguns proprietários rurais deram permissão aos seus trabalhadores para construírem casas em terras por si designadas. Reza a história local que a Cova da Moura terá tido a sua origem na permissão dada a José Moura, assalariado rural originário de Trás-os-Montes, para construir a sua casa na zona de uma pedreira entretanto desativada. Por esta razão, o seu filho, Manuel Moura, comerciante da Rua Principal, é hoje designado como um dos primeiros habitantes do bairro.

Os relatos que documentam a origem e desenvolvimento do bairro por cabo-verdianos, portugueses, são-tomenses, angolanos e guineenses, chegados das ex-colónias ou do interior rural de Portugal, são reveladores da história e geografia de um país em profunda transformação, bem como de um contexto colonial que se prolonga para além das independências africanas. Por outro lado, a perceção desta transformação por parte do poder público, que acompanhou desde cedo a ocupação deste território - desde o surgimento de hortas e abrigos construídos em madeira até à construção de casas de alvenaria -, dá origem a levantamentos e estudos sobre a Cova da Moura quase tão antigos quanto o próprio bairro e, em si mesmos, objetos discursivos constitutivos das narrativas-chave produtoras do lugar enquanto totalidade coerente.

Em janeiro de 1976, os Serviços de Fiscalização de Obras da então Câmara Municipal de Oeiras ${ }^{3}$ davam conta da construção de "cinco casas abarracadas em tijolo" e "caboucos para a construção de outras". Em 1977, a autarquia avançou com a realização de um estudo socioeconómico e identificou a demarcação de 203 lotes destinados a habitação, dos quais 103 se encontravam ocupados por construções de madeira, designadas por "barracas", e 90 por edifícios em alvenaria. Simultaneamente, propôs tomar posse administrativa dos terrenos e "recuperar o bairro" através da elaboração de um Plano de Urbanização, considerando que os seus habitantes teriam já "criado raízes" no lugar. Embora as medidas enunciadas não chegassem a ser postas em prática, acabariam por inviabilizar o pedido de urbanização feito pelos proprietários (Craveiro et al., 1983, pp. 18-27).

No terreno, quem construía estava ciente do risco de demolição da sua casa, desenvolvendo por isso um conjunto de estratégias que passavam sobretudo pela rápida progressão e ocupação da nova construção ${ }^{4}$. Ainda em 1977, terá sido um episódio de demolição de dezasseis casas, pela autarquia, que levou à constituição de uma Comissão de Moradores e, consequentemente, a um pedido de reunião com o então presidente da Câmara Municipal de Oeiras (Andrade Neves). Deste encontro resultou a colaboração entre a Câmara Municipal de Oeiras e a Comissão de Moradores, com vista à melhoria das condições de vida e habitabilidade do bairro. Com o apoio da autarquia na cedência de maquinaria e outros recursos, dão-se então as primeiras ligações elétricas pela EDP - Energias de Portugal -, inicia-se o traçado e a abertura de ruas, acompanhados pela atribuição da toponímia, bem como a instalação das redes de água e esgotos e a asfaltagem da Rua Principal e da Rua do Vale (Raposo \& Carolino, no prelo) (Figura 2).

Neste processo, a Comissão de Moradores adquiriu localmente especial protagonismo, que Ihe adveio não só da relação estabelecida com o município, mas também do cultivo de uma rede de relações interpessoais e alianças político-partidárias (vide Horta, 2000). Fazendo suas as preocupações do poder público, a Comissão procurou controlar a expansão do edificado, definindo e impondo determinados parâmetros construtivos, com destaque para o alinhamento das casas e a preservação da largura mínima das vias. Como recorda um antigo membro da sua equipa, "começámos a trabalhar [...] já como autoridade". Neste processo, a relação com os moradores era tensa, chegando a gerar-se momentos de aberto conflito. Para conseguir influenciar o decurso da construção, a Comissão insistiu que quem pretendesse construir deveria contactá-la previamente. A criação de uma "ficha de morador" por cada casa interessada na ligação à rede pública de água e saneamento básico foi um dos aspetos que reforçou o seu papel de interlocutor privilegiado entre moradores e poder público.

Esta conjuntura começou a alterar-se quando, em 1979, a recém-constituída Câmara Municipal da Amadora foi ganha pela Coligação Democrática Unitária $(C D U)^{5}$. Em 1981, a nova autarquia rei- 
Figura $2 \triangleright$ Planta de arruamentos, executado pela Comissão de Moradores

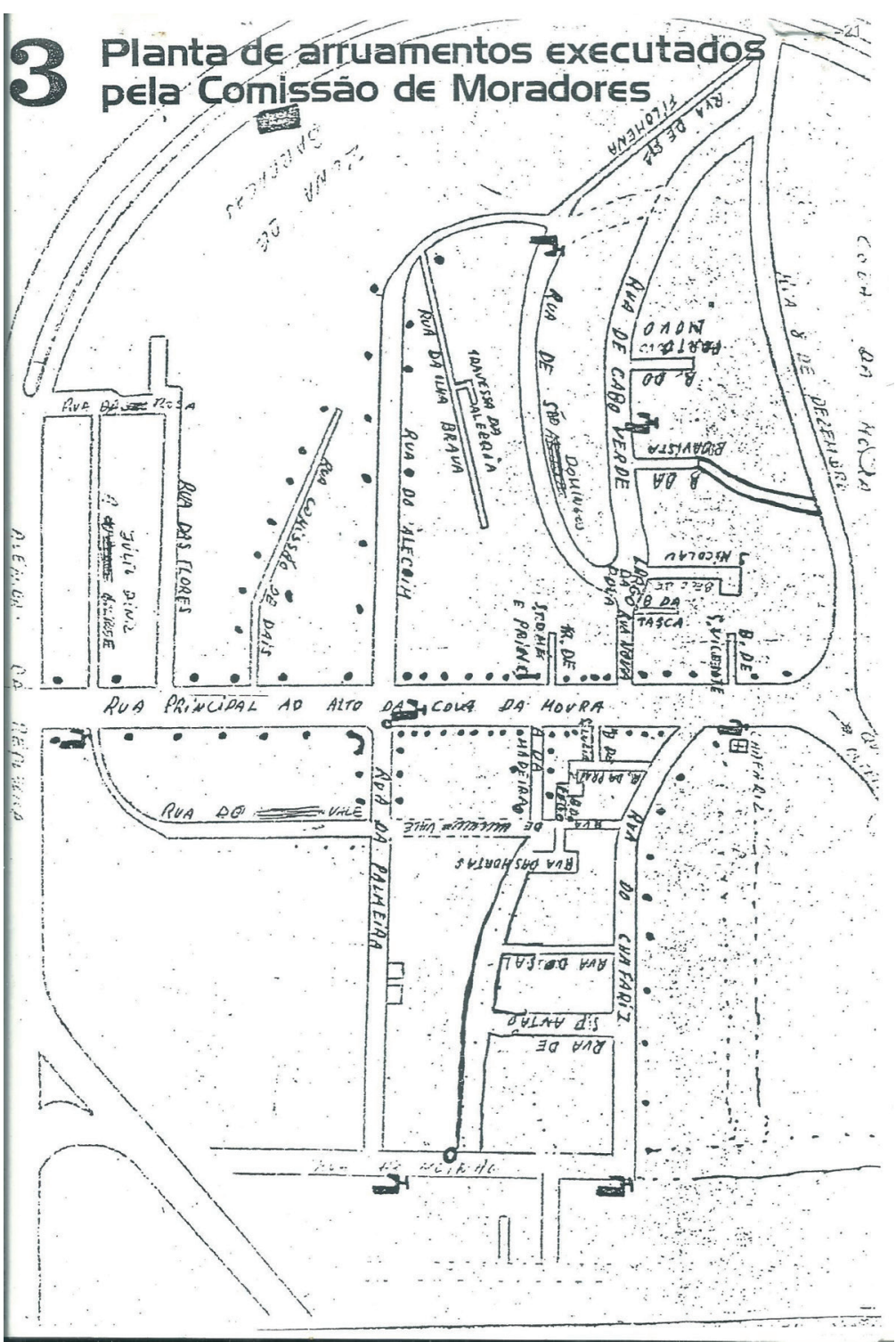

Fonte: Craveiro et al., 1983, p. 21

terou a posição do anterior executivo, indeferindo uma vez mais os pedidos de urbanização por parte dos proprietários do terreno. Um ano mais tarde, deliberou a expropriação do terreno por utilidade pública e avançou com uma "avaliação socioeconómica, jurídica e financeira da recuperação do bairro", conducente a propostas concretas de "recuperação" (Craveiro et al., 1983, pp. 19, 27-28).

Surgiu assim em 1983 o primeiro grande estudo da Cova da Moura (Craveiro et al., 1983), realizado por técnicos municipais, no qual se identificou um total de 836 edifícios, predominantemente em alvenaria, e uma ocupação em quarteirões muito mais extensiva do que a registada anteriormente
(Figura 3). Destacava-se, igualmente, o risco de densificação do edificado, por via da verticalização, chamando-se a atenção para o surgimento de uma "fase especulativa deveras preocupante que se vem delineando em torno desta ocupação". Os técnicos instavam a "uma intervenção decidida da Administração a todos os seus níveis (Central e Local), que discipline e regre a dinâmica construtiva" (Craveiro et al., 1983, p. 98), defendendo uma estratégia que valorizasse as dinâmicas locais e processos acompanhados de autoconstrução evolutiva. Não obstante a criação de um gabinete local, as medidas delineadas pela autarquia não chegaram, no entanto, a concretizar-se.

Na Cova da Moura, manteve-se a proximidade entre a Comissão de Moradores e a recém-criada Junta de Freguesia da Buraca, onde um dos elementos fundadores da Comissão de Moradores foi eleito pelo Partido Socialista como membro do poder executivo. Data deste período o loteamento realizado na parte sudeste do bairro, a última a ser ocupada, liderado pela Comissão de Moradores e que, embora não fosse legalmente reconhecido pelo Estado, contou com a colaboração da Junta de Freguesia. Uma preocupação em atribuir estes lotes a "portugueses" refletia um novo esforço no sentido de assegurar a "modernidade" e "boa reputação" da Cova da Moura, através da seleção criteriosa das pessoas que ocupariam uma zona particularmente visível do bairro a partir "de fora". Ironicamente, foi nesta zona que nasceu, em 1984, uma outra organização de moradores - a Associação Cultural Moinho da Juventude -, empenhada no empoderamento dos habitantes em situação de maior exclusão, promovendo a cultura e identidade africanas da Cova da Moura ${ }^{6}$.

Sem recorrer à Comissão de Moradores, este grupo de vizinhos, dependentes de um chafariz localizado na zona sudeste do bairro, organizou-se para, interpelando diretamente a Câmara Municipal, aceder à rede de água e saneamento básico, tendo recenseado 900 habitantes com esta necessidade, 
Figura $3 \triangleright$ Levantamento das tipologias construtivas (1983): a verde 'edifícios em alvenaria', a amarelo 'casas abarracadas' e a vermelho 'barracas'

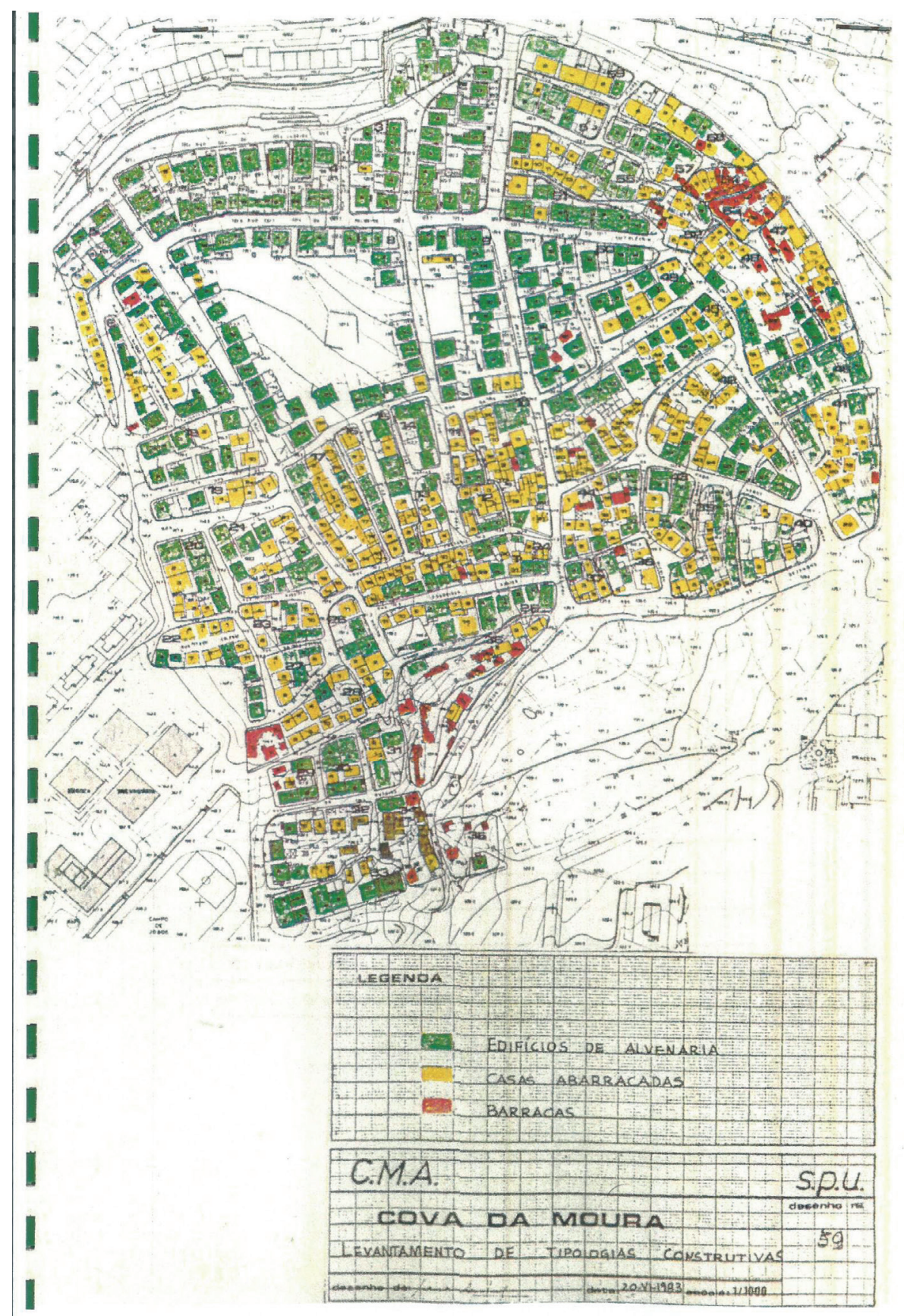

Fonte: Craveiro et al., 1983, p. 59

dispostos a contribuir para a resolução do problema. Em paralelo, criou uma biblioteca comunitária, destinada sobretudo às crianças, e, em diálogo com o Sindicato das Empregadas Domésticas (ocupação de muitas moradoras do bairro), envolveu-se na melhoria das suas condições de trabalho. Com a sua própria rede de relações e, ao longo do tempo, alguma projeção mediática, a Associação Cultural Moinho da Juventude veio progressivamente desafiar o protagonismo assumido anteriormente pela Comissão de Moradores, facto a que não será também indiferente o crescimento populacional associado sobretudo à migração laboral cabo-verdiana caraterística das décadas de 80 e 90 
(vide Malheiros \& Esteves, 2013). Ao apostar na importância da cultura como fator de integração e desenvolvimento, o Moinho da Juventude promove, e projeta na sociedade portuguesa, práticas culturais de tradição cabo-verdiana, como é o caso do Kola San Jon (Figura 4) - festa cabo-verdiana de São João -, obtendo, em 2013, a sua inscrição no Inventário Nacional do Património Cultural Imaterial?.

Figura $4 D$ Cultura e identidade na Cova da Moura. A Festa de Kola San Jon, 2012

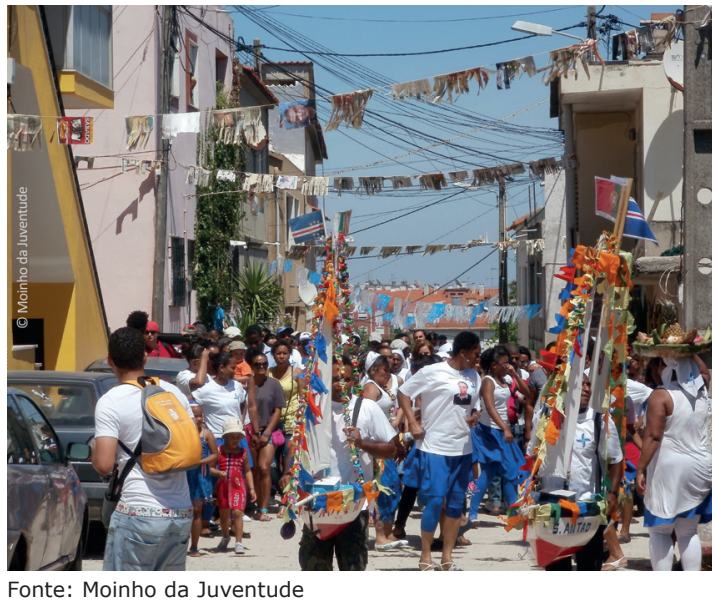

De um modo geral, pode dizer-se que, ao longo da década de 80 , se foi consolidando e diversificando a vida institucional do bairro. No mesmo período, pessoas ligadas à Comissão de Moradores haviam lançado já uma outra organização, que designaram por Clube Recreativo ${ }^{8}$. Também nesta década foi criada a Paróquia da Buraca e, com ela, o Centro Social e Paroquial. Nos anos seguintes, estas organizações criaram um conjunto diversificado de serviços destinados aos moradores, ao nível do apoio à infância, jovens, idosos, formação e emprego, documentação e outros. Entrou igualmente em funcionamento a escola pública do primeiro ciclo do ensino básico da Cova da Moura. Simultaneamente, a relação dos moradores com o bairro diversifica-se: por um lado, aos primeiros habitantes, que ali construíram as suas casas, junta-se a geração já nascida na Cova da Moura; por outro, o arrendamento expande-se progressivamente, até atingir valores tão expressivos quanto os dos donos das casas. No entanto, enquanto isso, a questão da regularização fundiária e urbanística do bairro permaneceu em aberto.

Com a eleição de Joaquim Raposo, do Partido Socialista, para presidente da autarquia, em 1993, depois de 12 anos de governação CDU, cresceram as esperanças, em especial por parte das associações politicamente mais próximas - a Comissão de Moradores e o Clube Recreativo -, de que fosse retomada a colaboração que marcara as relações com o congénere de Oeiras, no final da década de 70. Contudo, os tempos eram outros.

\section{(Re)afirmação do direito ao lugar}

O forte investimento e envolvimento municipal no período após o 25 de Abril de 1974, começou a diminuir com o privilegiar, a nível nacional e internacional, de políticas neoliberais, dirigidas para a lógica de mercado, assente na propriedade privada individual (vide Raposo \& Jorge, 2017; Hibou, 2011) e que equaciona as questões da qualificação urbanística e habitacional como objetos de intervenção iminentemente técnica. A partir de finais da década de 80 , com o aumento do mercado imobiliário e o anúncio da exibição da capital a nível internacional, através da Lisboa Capital Europeia da Cultura em 1994 e da Expo"98, registou-se um aumento da pressão para lidar com a grande visibilidade e extensão dos então denominados "bairros de barracas", localizados às portas de Lisboa (vide Cachado, 2013 ; 2018). Apoiado numa visão estigmatizada e estereotipada destes territórios, o Programa Especial de Realojamento (PER), publicado em 1993, surgiu enquanto resposta a este problema. Dirigido às áreas metropolitanas de Lisboa e do Porto, este programa assentou em três objetivos: erradicar as "barracas", envolver fortemente os municípios no processo de erradicação preconizado e potenciar, com o realojamento, uma mudança no estilo de vida dos moradores, partindo-se da ideia de que condições de habitação degradadas favorecem "comportamentos desviantes" (Cachado, 2013). A Câmara Municipal da Amadora recenseou, ao abrigo do PER, 6755 agregados familiares a realojar, sendo um dos municípios com mais famílias a viver nas designadas "barracas" (Salgueiro, 1985, p. 63). Apenas uma pequena parte dos habitantes do bairro da Cova da Moura ${ }^{9}$ foi considerada neste recenseamento (57 agregados). Tal não refletiria, contudo, uma imagem ou abordagem de intervenção por parte da autarquia necessariamente distintas, recaindo sobre a Cova da Moura uma visão igualmente estigmatizada e estereotipada, vinculada à noção de bairro "crítico" e "degradado". Nestes anos, preparam-se e entram em vigor instrumentos-chave para uma intervenção municipal ao nível do ordenamento do território, como a classificação da Cova da Moura como "área estratégica de desenvolvimento municipal", no âmbito do primeiro Plano Diretor Municipal, ratificado em 1994, e a atribuição do estatuto de "área crítica de recuperação e reconversão urbanística" (ACCRU) ${ }^{10}$. No diploma, o bairro é descrito como "uma estrutura habitacional, social e ambiental bastante degradada, com graves insuficiências de infra-estruturas urbanísticas, espaços verdes e equipamentos sociais", cabendo à Câmara Municipal "promover, em colaboração com as demais entidades interessadas, as 
acções e o processo de recuperação e reconversão urbanística da área".

A partir de 2000, a Cova da Moura, a par da Brandoa, foi abrangida pelo programa comunitário URBAN II, direcionado para a promoção e aplicação de "estratégias inovadoras de revitalização socioeconómica sustentável dos centros urbanos" ou dos "subúrbios em crise das grandes cidades" (CCDR, IFDR, 2010, p. 11). No âmbito do URBAN, o bairro é descrito como tendo uma "malha confusa", com "construções amontadas" e uma acessibilidade interna difícil devido à forte inclinação e à existência de passagens estreitas (CCDR, IFDR, 2010, pp. 19-20). Além das suas características físicas, aborda-se o problema da toxicodependência e de "um conjunto de atividades ilícitas" (CCDR, IFDR, 2010, pp. 19-20). Assumiram-se como objetivos estratégicos: requalificar o ambiente urbano e valorizar o espaço público; integrar a população local; revitalizar o ambiente social; e valorizar o contexto socioeducativo da população juvenil (CCDR, IFDR, 2010 , p. 22). Destacam-se os melhoramentos realizados no pavilhão desportivo, no Jardim Central da Buraca e no Jardim 25 de Abril, nas imediações do bairro, que acabariam por beneficiar de alguma forma os habitantes do bairro (vide Lages, 2017).

Em 2002, a Câmara Municipal avançou com a elaboração do primeiro Plano de Pormenor para o bairro. Desenvolvido por um gabinete privado Vasco da Cunha, Estudos e Projetos -, o Plano de Pormenor apontava para a necessidade de substituição de grande parte do edificado, de "abrir o bairro ao exterior" e de promover a construção de novos equipamentos e espaços verdes. Apoiado na demolição de cerca de $80 \%$ do edificado existente, propunha o realojamento dos moradores in situ, em "novos fogos sociais, em tipologia de acordo com o seu agregado familiar", mediante o pagamento de uma renda calculada em função dos rendimentos auferidos. Apenas para uma parte do bairro (156 edifícios, na zona norte) se previa a qualificação do tecido existente, recebendo os donos das casas em questão o estatuto de proprietários, responsáveis pela compra do terreno ocupado e pelo pagamento das infraestruturas necessárias, das taxas de legalização e de outras despesas inerentes ao processo (Câmara Municipal da Amadora, 2002).

Esta proposta suscitou grande contestação entre moradores e organizações locais, unidos pela qualificação do bairro, constituindo-se em 2004 a Comissão de Bairro da Cova da Moura, que conta, desde o início, com o apoio de uma equipa da Faculdade de Arquitetura da Universidade de Lisboa (então Universidade Técnica de Lisboa), nomeadamente ao nível da componente técnica. Estratégias e propostas alternativas à tabula rasa, de foro académico, são apresentadas no workshop "A reabilitação do bairro é possível se a gente quiser", no quadro da festa anual Kola San Jon, em 2005. No mesmo período, a Associação de Moradores (antiga Comissão de Moradores) liderou um processo coletivo que levou 60 moradores, a residir na Cova da Moura há mais de trinta anos, a formalizar uma ação de usucapião. Estes desenvolvimentos acabariam por reforçar o posicionamento da Comissão de Bairro, que representou os moradores e organizações locais ao longo da maior iniciativa pública de intervenção que se seguiu: a Iniciativa Bairros Críticos (IBC) ${ }^{11}$.

Esta iniciativa, desencadeada, entre 2005 e 2012, em três bairros piloto, um deles a Cova da Moura, pretendia "estimular e testar soluções institucionais, procedimentais e tecnológicas inovadoras em termos de concepção, implementação e avaliação da acção pública em áreas urbanas críticas". Assente num envolvimento interministerial, na participação de parceiros locais e em parcerias público-privadas, assumia uma mudança de paradigma ao nível da abordagem e intervenção sócio-territorial integrada (vide Lages, 2017). Coordenada pelo Instituto de Habitação e Reabilitação Urbana (IHRU) e, numa fase inicial, acompanhada de perto pela Secretaria de Estado do Ordenamento do Território, a Iniciativa Bairros Críticos deparou-se no terreno com uma realidade claramente polarizada, que opunha, por um lado, a Comissão de Bairro, em representação das organizações locais e dos moradores, e, por outro, a Câmara Municipal (vide Carolino, 2013).

O diagnóstico participado (Malheiros, Vasconcelos \& Alves, 2006a), validado por um Grupo de Parceiros Locais ${ }^{12}$, serviu de base aos eixos estratégicos delineados no Plano de Ação definido para o Bairro (Malheiros, Vasconcelos \& Alves, 2006b), que visava: a legalização e requalificação urbana, bem como a promoção de uma nova imagem do território, através do reforço da segurança, da sustentabilidade ambiental e da qualificação e diversificação da oferta cultural (Sousa, 2012, p. 31). Com base neste Plano de Ação, o IHRU solicitou ao Laboratório Nacional de Engenharia Civil (LNEC) o estudo das condições de habitabilidade do edificado e das necessidades de reabilitação, desenvolvido ao longo de 2008, com o apoio de mediadores locais (vide Ascensão, 2013; Carolino, 2013). No levantamento e análise efetuados a Cova da Moura foi caracterizada pela presença de problemas habitacionais, construtivos e urbanísticos, definindo-se três tipos de casos: de "reabilitação ligeira", de "reabilitação média" e de "reabilitação profunda" (Coelho et al., 2008).

Foi assim atribuído ao Plano de Pormenor um papel fundamental, uma vez que determinaria o edificado a reabilitar e a demolir. Tendo realizado e deixado disponível (sob a forma de uma base de dados de acesso restrito) uma caracterização detalhada (edifício a edifício), a equipa do LNEC sublinhou a necessidade de "uma articulação pormenorizada e estratégica" no âmbito dos trabalhos 
a desenvolver para a elaboração deste instrumento de ordenamento territorial, a fim de "potenciar as melhores características do espaço urbano e do edificado preexistentes com as melhores intenções urbanas e residenciais" (Coelho et al., 2008, p. 39).

Em 2010 iniciaram-se os trabalhos associados à elaboração do Plano de Pormenor, atribuídos (por concurso público internacional) ao mesmo gabinete que realizara a proposta de 2001 . Após várias etapas preparatórias, discutidas com a Câmara Municipal e, só depois, com a Comissão Executiva da IBC da Cova da Moura (onde tinha assento a Comissão de Bairro), o Gabinete apresentou em 2012 os primeiros cenários de intervenção, para debate, nos quais o realojamento in situ (dos moradores que declararam querer permanecer no bairro) foi contemplado, mas a par da demolição de grande parte do edificado, ainda que possivelmente dentro de tipologias mais próximas das existentes. Esta possibilidade não teve a aprovação da Comissão de Bairro, que contrapropôs com um processo participado, à escala do quarteirão, partindo da premissa da qualificação do tecido existente, sempre que possível (vide Carolino, 2013). Contudo, o processo foi, entretanto, interrompido. Em Março de 2012, o IHRU retirou-se, alegando falta de verbas para continuar, e a IBC foi formalmente extinta em dezembro do mesmo ano. Nos anos seguintes, as associações locais, apoiadas pela Faculdade de Arquitetura, procuraram articular uma via alternativa, participada, entregando ao município, em 2013, três propostas de intervenção assentes na qualificação gradual do espaço público, discutidas e construídas com as organizações locais e com grupos de habitantes. Sem qualquer resposta, as expetativas em torno da regularização e qualificação do bairro apenas reemergem recentemente, na sequência: por um lado, da reaproximação da família Canas, a maior proprietária dos terrenos onde se localiza a Cova da Moura, propondo a negociação de uma compensação ou uma permuta ${ }^{13}$; por outro, da criação da Secretaria de Estado da Habitação.

\section{Geração do "1.0 Direito"}

Perante a persistência de problemas estruturais no setor da habitação, denunciados, quer pelas associações, movimentos e coletivos da sociedade civil que lutam há vários anos pelo direito à habitação, quer inclusivamente pela relatora das Nações Unidas para a Habitação Adequada ${ }^{14}$ (UN, 2017), o governo português avançou em meados de 2017 com a criação de uma Secretaria de Estado da Habitação. Pouco tempo depois, foi oficialmente lançada uma Nova Geração de Políticas, que apresenta a habitação e a reabilitação como "instrumentos-chave para a melhoria da qualidade de vida das populações" e assume a missão de "[g]arantir o acesso de todos a uma habitação adequada" (SEH, 2017, p. 3). Mais recentemente, em fevereiro de 2019, foi criado - Ministério das Infraestruturas e da Habitação, reiterando a importância do tema da habitação no panorama político atual.

Propõe-se, no quadro da Nova Geração de Políticas, um novo olhar, mais amplo e transversal, sobre a problemática habitacional. Segundo se sublinha no documento orientador, a noção de "habitação" deve ser lida no sentido amplo de "habitat" e orientada para as pessoas, procurando "[c]riar as condições para que tanto a reabilitação do edificado como urbana passem de exceção a regra" (SEH, 2017 , p. 3). Pretende-se transitar de uma política de habitação apoiada na construção de novos alojamentos, como o PER, focada "na casa" e dirigida para a oferta pública de habitação destinada aos grupos de menores recursos, para uma política que privilegie a reabilitação e o arrendamento, dirigida a todos os que não conseguem aceder atualmente a uma habitação no mercado (SEH, 2017, pp. 6-8).

A definição e apresentação desta Nova Geração de Políticas foi acompanhada do primeiro Levantamento Nacional das Necessidades de Realojamento Habitacional realizado em Portugal, coordenado pelo IHRU e posto em prática através de um inquérito dirigido aos municípios. Procurou-se, através deste levantamento, sinalizar as atuais necessidades habitacionais a nível nacional, conhecer o número de famílias a viver em condições precárias e sistematizar as soluções preconizadas pelos municípios para a resolução destas mesmas carências (IHRU, 2018, p. 1). Os resultados revelaram a efetiva necessidade de medidas ao nível da habitação, tendo sido identificadas 25762 famílias em situação de carência, correspondentes a 14748 edifícios e 31526 fogos. O estudo revelou também ser a Área Metropolitana de Lisboa um dos contextos onde mais se coloca o problema, estando aí concentrados mais de metade dos casos identificados (IHRU, 2018, pp. 1-2) Os municípios da Amadora, Loures e Almada sinalizam, juntos, mais de 1000 famílias em situação de grave carência habitacional, a viverem sobretudo no que o inquérito designa de "barracas e construções precárias" (IHRU, 2018, p. 11). A Amadora destaca-se no topo da lista, com 2839 famílias identificadas. Um levantamento municipal, datado de dezembro de $2017^{15}$, sinaliza 35 "bairros degradados" no seu território, grande parte deles dados como "extintos", ao abrigo do PER, sendo a Cova da Moura apontada como um dos oito ainda "existentes".

No quadro da Nova Geração de Políticas de Habitação, foi publicado em junho de 2018 o $1 .^{\circ}$ Direito - Programa de Apoio ao Acesso à Habitação ${ }^{16}$ -, direcionado especificamente para os casos de maior precariedade habitacional, podendo aceder a este programa a pessoa ou o agregado que, cumulativamente, viva em condições indignas e esteja em situação de carência financeira (artigo 6.º). 
Outro critério de elegibilidade é o de ser detentor de cidadania portuguesa ou título de residência válido no território nacional, facto que levanta a questão de até que ponto se salvaguarda, assim, o acesso a uma habitação condigna enquanto um direito universal. Contemplando a possibilidade de uma intervenção mais territorial, define modalidades de intervenção para "núcleos precários" e "núcleos degradados". Por "núcleos precários", entendem-se as "construções não licenciadas, acampamentos ou outras formas de alojamento precário ou improvisado" - "mantendo entre si contactos subsumíveis do conceito de relações de proximidade e vizinhança" (artigo $11 .^{\circ}$ ) -, para os quais se prevê a possibilidade de realojamento em novas construções ${ }^{17}$ ou a reabilitação do tecido preexistente, inserida num processo de legalização, se garantidas condições mínimas de habitabilidade (n. ${ }^{\circ} 3$ do artigo $11 .^{\circ}$ ). Neste caso, além das soluções individuais de realojamento, contempla-se uma solução habitacional promovida pelo município, diretamente ou através de soluções coletivas apresentadas pelos próprios beneficiários, "[a]grupados sob a forma de associação de moradores ou de cooperativa de habitação e construção" (n.0 2, alínea c) do artigo 11.0 $)^{18}$. Os "núcleos degradados", por sua vez, referem-se a "áreas urbanas degradadas cujas edificações [...] constituam núcleos habitacionais com uma identidade própria e diferenciada", como as chamadas ilhas, pátios ou vilas (artigo $12 .^{\circ}$ ), para os quais se preconiza a reabilitação, a efetuar pelos proprietários das edificações ou por entidades gestoras, no caso de operações de reabilitação urbana sistemáticas (n.0 4 do artigo $\left.12 .{ }^{\circ}\right)^{19}$. Desde que a situação o justifique, contempla-se ainda a conjugação de diferentes soluções, como a aquisição de terrenos e a reabilitação dos edifícios neles existentes (artigo $28 .^{\circ}$ ), apontando assim saídas para casos em que a questão fundiária seja necessariamente o primeiro passo a dar.

Ao nível da construção e implementação das soluções apresentadas, destaca-se a possibilidade de cooperação e participação de diferentes tipos de atores, públicos ou privados, na definição e concretização dos procedimentos que assegurem as soluções habitacionais encontradas (artigo $3 .{ }^{\circ}$ ). A par de "beneficiários diretos" - as pessoas que preenchem os requisitos de acesso -, o Programa define "entidades beneficiárias", que podem receber apoio para a promoção de soluções habitacionais a pessoas e agregados elegíveis na qualidade de "beneficiários diretos". Podem participar, com este estatuto, o Estado e as empresas, entidades ou institutos públicos, bem como as misericórdias e instituições particulares de solidariedade social (IPSS) e pessoas coletivas de interesse público, as associações de moradores, as cooperativas de habitação e construção e, ainda, os proprietários de frações ou prédios localizados em núcleos degradados (artigo 26. ${ }^{\circ}$ ). Por último, tendo em conta a sua "proximidade com os cidadãos e com o território" (preâmbulo), é atribuído às autarquias um "papel imprescindível e instrumental". Cabe ao município, antes de mais, definir uma estratégia local de habitação e priorizar as soluções habitacionais que pretender ver desenvolvidas no seu território, devendo as candidaturas enquadrar-se nessa mesma estratégia (artigo 30.․).

No âmbito deste novo pacote de políticas, a Secretaria de Estado da Habitação promoveu um amplo debate e a divulgação das medidas anunciadas, quer na fase de discussão pública, quer por ocasião da sua entrada em vigor. Foi neste contexto que os representantes das associações que integram a Comissão de Bairro da Cova da Moura tomaram contacto com as medidas anunciadas e procuraram recolocar na agenda pública o caso do seu bairro, ainda pendente de uma intervenção pública dirigida à resolução da situação fundiária, urbanística e habitacional. Em janeiro de 2018 reúnem com a secretária de Estado, Ana Pinho, e em setembro de 2018 obtêm esclarecimentos adicionais por parte do corpo técnico do IHRU, passando a depositar algumas esperanças no $1 .^{\circ}$ Direito.

Embora seja necessário conhecer, antes de mais, a estratégia de habitação definida pelo município, este programa levanta algumas questões, analisadas à luz do caso do Bairro da Cova da Moura. Ao permitir, enquanto situações específicas, a procura de soluções coletivas e o envolvimento de atores locais, como as associações de moradores e outras formas de organização dos beneficiários, o programa poderá encontrar respostas para casos como o da Cova da Moura, há muito em aberto, incorporando as dinâmicas complexas e participadas próprias do lugar. No entanto, as categorias territoriais propostas, de "núcleo precário" e "núcleo degradado", apresentam algumas limitações. Focadas quase exclusivamente nas características urbanísticas e nas suas dimensões mais problemáticas, estas categorias transportam em si uma carga negativa e pejorativa, que as aproxima das situações abrangidas pelo congénere $P E R$, não integrando como recursos para a intervenção a história e a identidade consolidadas no bairro enquanto lugar. $\mathrm{O}$ potencial enfoque territorial é limitado, igualmente, ao considerar-se como beneficiários diretos do $1 .^{\circ}$ Direito exclusivamente as famílias em situação de carência financeira, excluindo uma grande parte dos moradores, entre eles os proprietários das construções com melhores condições de habitabilidade, inviabilizando, assim, uma intervenção integrada e abrangente, à escala de todo o bairro. Da mesma forma, ficam ainda fora do programa os moradores que não tenham a sua situação regularizada no país, impedindo, como referido anteriormente, a leitura do direito à habitação enquanto direito universal. 
Ao atribuir um papel também aos proprietários, a categoria "núcleo degradado" aproxima-se mais da realidade complexa que caracteriza, como vimos, a composição e as dinâmicas da Cova da Moura, embora, na sua definição, ambas as categorias procurem, à sua maneira, dar conta de elementos que remetem para a dimensão do lugar: no caso dos "núcleos precários", contemplam-se as "relações de proximidade e de vizinhança" (artigo 11. ${ }^{\circ}$, ponto 1 ), enquanto no caso dos "núcleos degradados" se sublinha a sua suposta "identidade própria e diferenciada no espaço urbano" (artigo $12 .^{\circ}$, ponto 1 ).

\section{Conclusões}

Apesar do esforço financeiro na promoção pública de habitação nas últimas décadas, várias famílias continuam em Portugal a aguardar o acesso a uma habitação adequada e a condições de vida condignas ou, simplesmente, a salvaguarda do direito ao lugar e à habitação. Com a recém-criada Secretaria de Estado da Habitação, comprometida em garantir o acesso de todas e todos a uma habitação e a passagem da reabilitação de exceção a regra, que outras possibilidades se levantam ao nível dos territórios autoproduzidos?

Cruzando uma análise da produção do lugar, à luz do caso do bairro da Cova da Moura, com a das perspetivas recentemente abertas pela Nova Geração de Políticas de Habitação, procurámos averiguar de que modo, e até que ponto, poderá o programa $1 .^{\circ}$ Direito, dirigido para os casos de maior precariedade habitacional, contribuir para a regularização deste território autoproduzido. A par de elementos que surgem como potencialmente favoráveis a este fim, identificámos outros que poderão ser limitadores, ao reduzir a poucas dimensões, iminentemente técnicas e jurídicas, uma realidade muito mais complexa, característica do processo de produção do lugar.

$\mathrm{Na}$ análise levada a cabo, vimos que a constituição do bairro, com a sua história e identidade específicas, envolveu um longo processo, marcado por formas de ação e visões de possibilidade diferentes entre si, revelando uma realidade local plural e negociada, marcada por distintos protagonismos. Por outro lado, vimos também que a mesma incorporou desde muito cedo a perceção de que o bairro não se faria e defenderia apenas com os que ali habitam, desenvolvendo-se antes em relação com o poder público, relação essa também ela multifacetada e mutável ao longo do tempo. Nesta análise, foram-se revelando as estratégias desenvolvidas pelos atores, com o intuito de assegurar um direito a permanecer num espaço da cidade cada vez mais central e, por isso mesmo, apetecível do ponto de vista imobiliário, onde foram desenvolvendo formas de relação, identificação e pertença próprias do lugar. Em face desta complexidade, precisamos de nos demarcar de uma visão estritamente técnica dos desafios em aberto, retomando um olhar sociopolítico que fomos designando como de luta pelo direito ao lugar.

\section{Notas}

1 Preâmbulo do Decreto-Lei n. ${ }^{\circ}$ 163/1993, de 7 de maio.

2 Decreto-Lei n. 0 37/2018, de 4 de junho.

3 O território em questão era, à data, parte integrante da autarquia de Oeiras. Apenas em 1979 foi criado o município da Amadora, de que o bairro da Cova da Moura faz hoje parte.

${ }^{4}$ Era comum o esforço de, reunindo familiares, amigos e/ /ou contratando alguém, construir intensivamente durante um fim-de-semana, para modo evitar que a obra fosse identificada pelas autoridades antes de ter um teto e dar sinais de ser ocupada para habitação.

5 A CDU é uma coligação formada pelo Partido Comunista Português e pelo Partido Ecologista "Os Verdes".

${ }^{6}$ Sobre a projeção de uma identidade cabo-verdiana para o bairro, ver o documentário realizado e produzido por Rui Simões em 2008, intitulado I/ha da Cova da Moura.

7 Direção-Geral do Património Cultural, Anúncio n. ${ }^{\circ}$ 323/2013, publicado em Diário da República, 2. a série, N. ${ }^{\circ} 200$, de 16 de outubro de 2013.

8 "O Clube", como é conhecido ainda hoje localmente, alterou mais tarde a designação para "Associação de Solidariedade Social do Alto da Cova da Moura".

9 Levantamento disponível em: http://www.cm-amadora. pt/intervencao-social/habitacao-social.html (acesso realizado em outubro de 2018).

10 Decreto n. 0 53/2003, de 11 de dezembro.

${ }_{11}$ Resolução do Conselho de Ministros n. ${ }^{\circ}$ 143/2005, de 2 de agosto, publicada em Diário da República, I Série - B, de 7 de setembro de 2005 .

12 O Grupo de Parceiros Locais era composto por um total de 28 instituições.

13 Ver, por exemplo, o artigo intitulado "A Cova da Moura tem dono e todos lucram à nossa conta", assinado por Valentina Marcelino e publicado no Diário de Notícias a 24 de outubro de 2016.

${ }^{14}$ Na sequência da sua visita a Portugal, em dezembro de 2016.

15 Disponível em: http://www.cm-amadora.pt/intervencao-social/habitacao-social.html (acesso realizado em outubro de 2018).

${ }^{16}$ Decreto-Lei n. 0 37/2018, de 4 de junho.

17 Mediante a aquisição de terrenos e a construção ou aquisição de edifícios habitacionais.

${ }^{18}$ Na mesma alínea especifica-se, ainda: "para atribuição de habitações em arrendamento ou propriedade resolúvel".

19 Caso os proprietários se oponham a esta operação, está previsto o recurso à tomada de posse administrativa ou a expropriação por utilidade pública (n. 04 do artigo $12{ }^{\circ}$ ). 


\section{Referências bibliográficas}

Ascensão, E. (2013). Following engineers and architects through slums: the technoscience of slum intervention in the Portuguese-speaking landscape. Análise Social, 206(XLVIII), 154-180.

Augé, M. (2005). Não lugares: introdução a uma antropologia da sobremodernidade. Venda Nova: Bertrand.

Cachado, R. (2013). O Programa Especial de Realojamento. Ambiente histórico, político e social. Análise Social, 206(XLVIII), 135-152.

Cachado, R. (2018). O fim das políticas de habitação social? In A. Carmo, E. Ascensão, A. Esteves (Eds.) , A Cidade em Reconstrução: leituras críticas, 2008-2018 (pp. 155-162). Odivelas: Outro Modo Cooperativa Cultural.

Câmara Municipal da Amadora (2002). Plano de Pormenor do Bairro do Alto da Cova da Moura. Estudo prévio. Policopiado.

Carolino, J. (2013, março). Contribuições de um enfoque antropológico no lugar para a temática da requalificação habitacional. O caso da Cova da Moura. In Atas do Segundo Congresso Internacional da Habitação no Espaço Lusófono, Lisboa: LNEC.

Carolino, J. (2015). Kola San Jon e o direito à cidade em Lisboa. Colóquio Cultura Proibida, Património Estimado (pp. 56-64). Amadora: ACMJ.

Casey, E. (1996). How to Get from Space to Place in a Fairly Short Stretch of Time. Phenomenological Prolegomena. In S. Feld \& K. Basso (Eds.), Senses of Place (pp. 13-52). Santa Fe: School of American Research Press.

Coelho, A. B., et al. (2008). Colaboração do LNEC na Análise das Condições de Habitabilidade do Edificado Existente no Bairro do Alto da Cova da Moura. Avaliação das Necessidades de reabilitação do Edificado. Relatório de Síntese. Lisboa: LNEC.

Comissão de Coordenação e Desenvolvimento Regional de Lisboa e Vale do Tejo (CCDR) e Instituto Financeiro do Desenvolvimento Regional (IFDR) (2010). Relatório de Execução Final, Programa de Iniciativa Comunitária Urban II Amadora (Damaia-Buraca) 2000-2006. Lisboa: CCDR e IFDR.

Craveiro, T., et al. (1983). Caracterização do Bairro Alto da Cova da Moura. Amadora: Departamento de Urbanismo da Câmara Municipal da Amadora.

Decreto n.o 53/2003 de 11 de Dezembro. Diário da República n.o 285/2003, Série I-B. Lisboa: Ministério das Cidades, Ordenamento do Território e Ambiente

Decreto-Lei n.o 163/1993 de 7 de Maio. Diário da República n.o 106/1993, Série I-A. Lisboa: Ministério das Obras Públicas, Transportes e Comunicações

Decreto-Lei n. 0 37/2018 de 4 de Junho. Diário da República n.o 106/2018, Série I. Lisboa: Presidência do Conselho de Ministros

Fabiana, P. (2017). Turismo e mercantilização da cidade. Espaços Vividos e Espaços Construídos, 5(1), 21-28.
Gupta, A., \& Ferguson, J. (1997). Culture, Power, Place: Ethnography at the End of an Era. In A. Gupta \& J. Ferguson (Eds.), Culture, Power, Place. Explorations in Critical Anthropology (pp. 1-29). Durham e Londres: Duke University Press.

Hibou, B. (2011). O ilegal na cidade moderna. In I. Raposo (Ed.), Relatório final do projecto de investigação: PTDC/AUR/71721/2006 - Reconversão e reinserção urbana de bairros de génese ilegal. Avaliação socio-urbanística e soluções integradas de planeamento estratégico (pp. 81-103). Lisboa: Centro de Investigação em Arquitetura, Urbanismo e Design.

Hirsch, E. (1995). Introduction. Landscape: Between Place and Space. In E. Hirsch \& M. O'Hanlon (Eds.), The Anthropology of Landscape. Perspectives on Place and Space (pp. 1-30). Nova Iorque: Claredon Press.

Horta, A. (2000). Constructing Otherness: Nationhood and Immigration Politics in Portuguese Post-colonial Society (tese de doutoramento). Ottawa: Simon Fraser University.

Instituto da Habitação e da Reabilitação Urbana - IHRU (2018). Levantamento Nacional das Necessidades de Realojamento Habitacional. Lisboa: IHRU.

Lages, J. (2017). À Conquista de Justiça Espacial. Intervenções Liminares em Territórios Autoproduzidos na Área Metropolitana de Lisboa (tese de doutoramento). Lisboa: Faculdade de Arquitectura da Universidade de Lisboa.

Lefebvre, H. (1991). The Production of Space. Oxford: Blackwell.

Malheiros, J., \& Esteves, A. (coords.). (2013). Diagnóstico da População Imigrante em Portugal. Desafios e Potencialidades. Lisboa: ACIDI.

Malheiros, J., Vasconcelos, L., \& Alves, F. (2006a), Operação Cova da Moura - Volume I: Diagnóstico. Iniciativa Bairros Críticos.

Malheiros, J., Vasconcelos, L., \& Alves, F. (2006b), Operação Cova da Moura - Volume II: Plano de Ação e Modelo de Gestão. Iniciativa Bairros Críticos.

Massey, D. (2006). For space. Londres: Sage.

Nações Unidas (2017). Report of the Special Rapporteur on adequate housing as a component of the right to an adequate standard of living, and on the right to non-discrimination in this context: Mission to Portugal. Nova Iorque: Nações Unidas.

Raposo, I., \& Carolino, J. (no prelo). Cova da Moura, que Desígnio, que Desenho. Lisboa: Faculdade de Arquitetura da Universidade de Lisboa

Raposo, I., \& Jorge, S. (2017). Qualificação de bairros peri-centrais autoproduzidos em Lisboa e Maputo: virtudes e vicissitudes dos processos. Espaços Vividos e Espaços Construídos, 3(1), 37-50.

Raposo, I. (2009, junho). Intervenção pública num bairro "crítico", o Alto da Cova da Moura. Comunicação apresentada no VI Seminário Internacional Arquitetura e Cosmologia (não publicado).

Raposo, I. (2012). Bairros de génese ilegal: metamorfoses dos modelos de intervenção. In M. Mendes, 
C. Ferreira, T. Sá \& J. Crespo (coords.), A cidade entre bairros (pp. 107-119). Casal de Cambra: Caleidoscópio.

Raposo, I., Carolino, J., Crespo, J., \& Jorge, S. (2012). Os instrumentos urbanísticos como arena social e a perceção do direito à cidade: a regeneração urbana da Vertente Sul de Odivelas. In Atas do VII Congresso Português de Sociologia. Porto: Universidade do Porto.

Salgueiro, T. B. (1985). A habitação na Área Metropolitana de Lisboa. Sociedade e Território, 3, 54-66.

Secretaria de Estado da Habitação - SEH (2017). Para uma Nova Geração de Políticas de Habitação:
Sentido Estratégico, objetivos e instrumentos de atuação. Lisboa: Secretaria de Estado.

Sousa, S. (2012). Registo do Processo - Iniciativa Bairros Críticos. Não publicado.

Souza, M. (2011). A cidade, a palavra e o poder: práticas, imaginários e discursos heterónomos e autónomos na produção do espaço urbano. In A. Carlos, M. Souza \& M. Sposito (Orgs.), A produção do espaço urbano, agentes e processos, escalas e desafios (pp. 149-166). São Paulo: Editora Contexto.

Tuan, Y. (1977). Space and Place. The Perspective of Experience. Londres: University of Minnesota Press.

Sílvia Jorge (aivlisjorge@gmail.com) Faculdade de Arquitetura da Universidade de Lisboa, Grupo de Estudos Sócio-Territoriais, Urbanos e de Ação Local do Centro de Investigação em Arquitetura, Urbanismo e Design GESTUAL-CIAUD, Rua Sá Nogueira, 1349-063 Lisboa

Júlia Carolino (jcarolino@outlook.pt) Faculdade de Arquitetura da Universidade de Lisboa, Grupo de Estudos Sócio-Territoriais, Urbanos e de Ação Local do Centro de Investigação em Arquitetura, Urbanismo e Design GESTUAL-CIAUD, Rua Sá Nogueira, 1349-063 Lisboa 


\title{
ESPAÇOS NEM-NEM - NEM PÚBLICOS NEM PRIVADOS EM EDIFÍCIOS DE HABITAÇÃO SOCIAL DE GRANDE PORTE
}

\section{SPACES NEITHER-NOR - NEITHER PUBLIC NOR PRIVATE IN LARGE-SCALE SOCIAL HOUSING BUILDINGS}

\author{
Teresa Madeira da Silva \\ $\square$ ISCTE-IUL, Instituto Universitário de Lisboa, Escola de Tecnologias e Arquitetura, Departamento de Arquitetura e \\ urbanismo / DINAMIA'CET-IUL
}

\begin{abstract}
Resumo
A partir do estudo de dois conjuntos de habitação social construídos em Marvila (Lisboa), conhecidos por Zona J e Pantera Cor-de-Rosa, propomos investigar o modo como se organizam e são utilizados os espaços de circulação e acessos em edifícios de grande porte organizados em galeria. Além dos espaços públicos e privados verificámos a existência de espaços semipúblicos, aqui designados de nem-nem, nem públicos nem privados, que correspondem aos espaços de circulação, no interior dos edifícios partilhados por vários lotes: corredores, galerias, halls, passadiços (circulações horizontais), ou escadas, rampas e elevadores (circulações verticais), cuja apropriação é pouco clara. 0 modo como esses espaços se organizam traz consequências positivas e negativas para os seus habitantes. Por um lado, é propício ao estabelecimento de relações de pertença pela apropriação por parte dos seus moradores, por outro, é motivo e área de conflito entre moradores de diferentes lotes, tornando a gestão difícil pela deficiente definição dos limites entre público e privado.
\end{abstract}

Palavras-chave: habitação social; espaços nem-nem; modelos arquitetónicos

\section{Abstract}

Departing from the study of two social housing building sets located in Marvila (Lisbon), called Zona $\mathrm{J}$ and Pantera Cor-de-Rosa (Pink Panther), we propose to investigate how the circulation spaces and accesses are used on gallery organized large buildings. In addition to the public and private spaces, we have confirmed the existence of semi-public areas, here called "neither-nor" - neither public nor private -, correspondents to the circulation spaces within the buildings and shared by several lots: corridors, galleries, halls, walkways (horizontal circulations), or stairs, ramps and elevators (vertical circulation), where the appropriation is unclear. The way these spaces are organized has both positive and negative consequences for its inhabitants. On one hand, it is conducive to the establishment of belonging relations by its inhabitants on the appropriation process, on the other hand, it is conflict motive and arena between residents of different lots, making local building management difficult due to the poor definition of the boundaries between public and private.

Keywords: social housing; neither-nor spaces; architectural models

\section{Introdução}

Pretende-se aprofundar o debate sobre o modo de organização e de utilização dos espaços de circulação em dois conjuntos de edifícios de habitação social de grande porte construídos em
Marvila (Lisboa), conhecidos por Zona J (Figura 1), e Pantera Cor-de-Rosa (Figura 2).

Os dois conjuntos, projetados e construídos nas décadas de 70 e 80 do século XX, situam-se, respetivamente, no bairro do Condado e no bairro dos Lóios, na zona oriental da cidade. Foram construídos 
Figura $1 \triangleright$ Zona J, bairro do Condado, Marvila, Lisboa

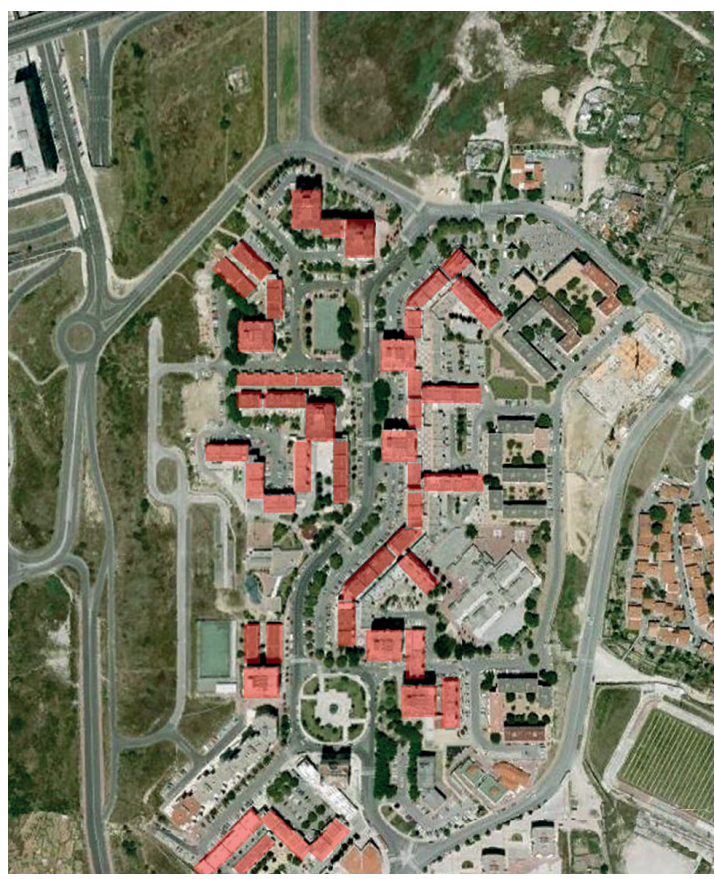

Fonte: Silva, 2011, a partir de fotografia aérea de: https://www.google.pt/maps

após a revolução de abril de 1974 com o intuito de alojar principalmente retornados das ex-colónias e população que vivia em barracas nestas e noutras zonas da cidade. A construção da maioria destes bairros correspondeu à resposta necessária a um problema quantitativo - o défice de habitação que se verificava à época. Decorridos cerca de 40 anos desde a sua construção, estes conjuntos urbanos apresentam apreciáveis níveis de deterioração e indícios de inadequabilidade, proporcionando uma fraca qualidade de vida urbana.

Questionámos o facto de a tipologia urbana, neste caso, edifícios de grande porte, organizados em galeria, onde o acesso às habitações é feito a partir de espaços designados de espaços nem-nem (de nem são públicos nem são privados), por analogia com o termo utilizado para a geração nem-nem ${ }^{1}$, ter reflexos na forma como os seus habitantes utilizam e usufruem esses mesmos espaços.

\section{Definição de conceitos e revisão bibliográfica}

Para aprofundar o debate sobre a questão da organização dos espaços de circulação em edifícios de grande porte em galeria importa estabelecer as diferenças entre alguns conceitos a fim de construir um quadro conceptual que fundamente teoricamente os conceitos utilizados, nomeadamente as conceções de espaço público, privado, semipúblico, espaço comum e espaço nem-nem.
Figura $2 \gg$ Pantera Cor-de-Rosa, bairro dos Lóios, Marvila, Lisboa

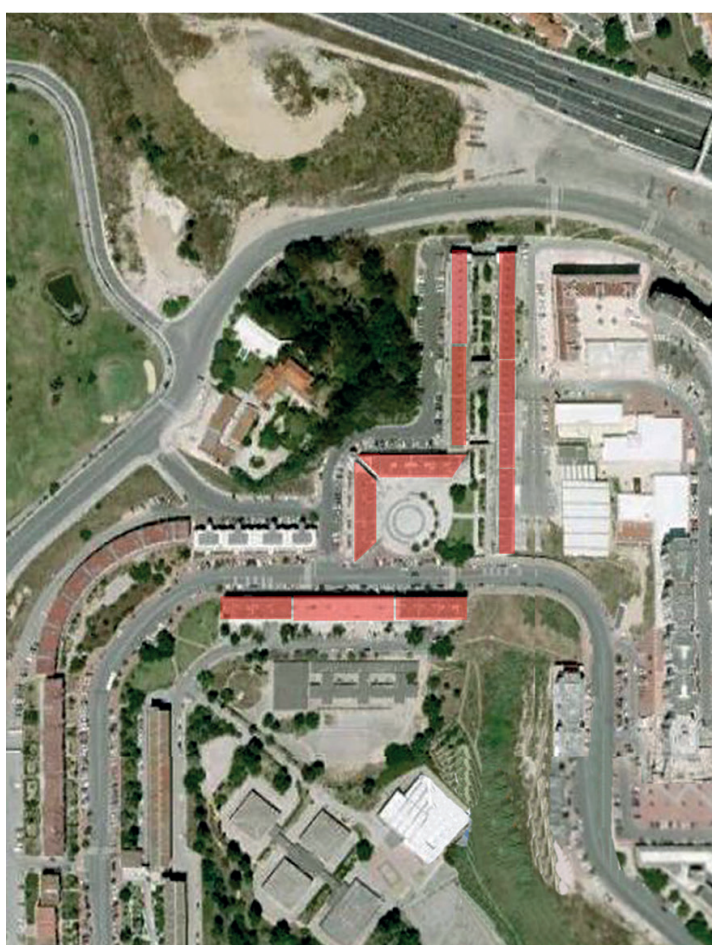

Fonte: Silva, 2011, a partir de fotografia aérea de: https://www.google.pt/maps

Apesar de fazermos uma abordagem a partir da morfologia urbana, ou seja, a partir da forma como se organizam os espaços, consideramos que esta se prende com o "modo de utilização e de comunicação figurativa que constitui a 'arquitetura da cidade'" (Lamas, s. d., p. 44). Assim, na linha de Hertzberg (1996), consideramos espaço público a "área acessível a todos a qualquer momento; [sendo que] a responsabilidade pela sua manutenção é assumida coletivamente" (Hertzberger, 1996, p. 12). Por outro lado, espaço privado "é uma área cujo acesso é determinado por um pequeno grupo ou por uma pessoa, que tem a responsabilidade de mantê-la" (Hertzberger, 1996, p. 12). Em contexto urbano, o espaço público é normalmente o espaço que envolve os edifícios, sendo que as vias são o espaço público predominante da imagem urbana de uma cidade (Lynch, 1988, p. 58). Por oposição, o espaço privado situa-se normalmente no interior dos edifícios. Para Hertzberger, porém, a oposição entre o público e o privado é excessiva, uma vez que as pessoas e os grupos estão sempre "em inter-relação e compromisso mútuo" (Hertzberger, 1996, p. 12). Para este autor, as demarcações territoriais são sempre relativas, em função dos espaços com os quais se relacionam. "Às vezes o grau de acesso é uma questão de legislação, mas, em geral, é 
exclusivamente uma questão de convenção, que é respeitada por todos" (Hertzberger, 1996, p. 15). No caso dos edifícios em estudo, é visível a indefinição entre público e privado, uma vez que existe um conjunto de espaços comuns, ou seja, partiIhados por habitantes de diferentes lotes, que não são privados, porque não são afetos diretamente a qualquer morador ou proprietário, mas também não são públicos, porque pertencem aos edifícios e, por isso, não são claramente acessíveis a todos. Esses espaços - corredores, galerias, halls, passadiços (circulações horizontais), ou escadas, rampas e elevadores (circulações verticais) - são considerados semipúblicos, porque, apesar de pertencerem aos edifícios, não são delimitados em relação ao espaço público. Dada a sua indefinição, estes espaços são aqui designados de espaços nem-nem.

Destacamos, igualmente, alguma bibliografia de referência para fundamentar a análise dos casos de estudo. As obras de Jane Jacobs (2007) e de Ferreira dos Santos et al. (1985) estudam o funcionamento das cidades e as relações entre tipologia do espaço público e segurança, sendo estes autores críticos do planeamento urbano moderno por este não valorizar a escala humana e a função social da cidade. Para estes autores, a ausência de diversidade implícita no planeamento racionalista de tradição modernista cria problemas de insegurança nas populações que neles habitam. Também o dossier temático "as pessoas não são coisas que se ponham em gavetas", coordenado por Ferreira, Guerra \& Freitas (1994), serviu de referência porque questiona, "do ponto de vista social, os efeitos perversos da concentração espacial de uma população socialmente homogénea" (Guerra, 1994, p. 11). Segundo os autores, no caso de Lisboa, esses efeitos "provocaram um crescimento exponencial de comportamentos desviantes e de estigmas socias que desencadearam, por sua vez, respostas violentas e um clima de insegurança..." (Guerra, 1994, p. 11). Teresa Valsassina Heitor trata da vulnerabilidade dos conjuntos urbanos de habitação social em Chelas, pressupondo que o seu "o padrão espacial (...) pode contribuir para tornar o espaço construído vulnerável a ações de negligência e a comportamentos transgressivos por parte da população" (Heitor, 2001, p. 3). Com um ponto de vista diferente, Bristol (1991), a propósito do conjunto habitacional Pruitt-Igoe, refere que é um mito responsabilizar o projeto arquitetónico de Pruitt-Igoe pelo seu fracasso, uma vez que toda a história desse fracasso envolve questões económicas e condições políticas. Para a autora, esta associação só serve para legitimar a profissão do arquiteto por tornar implícito que problemas sociais se resolvem através do projeto arquitetónico.

Para a realização da análise e do diagnóstico dos dois conjuntos urbanos, vários estudos serviram de referência, tais como: a "Operação Cova da Moura", (Malheiros, Vasconcelos \& Alves, 2006), a "Operação Vale da Amoreira" (2006), e a "Operação Lagarteiro" (Marques, 2006). Estes estudos apoiaram a metodologia adotada no estudo dos dois conjuntos habitacionais. Contributos para o Plano Estratégico de Habitação 2008/2013 - Documento Políticas Urbanas, elaborado pelo CET/ISCTE, ajudou-nos a contextualizar os bairros nas políticas da habitação em Portugal (Guerra, Pereira, Fernandes, Botelho \& Marques, 2008).

\section{Enquadramento e análise morfológica dos edifícios}

Os dois bairros de habitação social foram objeto de um Estudo de Avaliação e Diagnóstico das Necessidades de Intervenção no edificado realizado em 2011 (Silva, 2011) ${ }^{2}$. O objetivo do estudo era dotar o Programa Viver Marvila de um documento de suporte às intervenções no edificado, tendo em consideração as problemáticas de cada lote ou conjunto de lotes, apresentar propostas técnicas e financeiras sustentáveis e otimizar o bom desempenho funcional das construções, assegurando a durabilidade de futuras intervenções. Tendo por base o estudo, cujo foco é a intervenção no edificado, iremos tratar questões relacionadas com os aspetos morfológico e de organização dos espaços de circulação e acessos nos dois conjuntos, centrando as nossas questões na área disciplinar da arquitetura.

Bairro do Condado (Zona J). Propriedade da Câmara Municipal de Lisboa, os edifícios, projetados pelo arquiteto Tomás Taveira, foram construídos na década de 80 e desde 2003 até agora são geridos pela GEBALIS (Empresa de Gestão do Arrendamento da Habitação Municipal de Lisboa, EM, SA).

Em termos de composição urbana, o conjunto principal foi construído a partir de dois grupos de lotes em banda paralelos, resultando, desse alinhamento, um espaço-corredor de carácter público, com cerca de 6 metros de largura, 300 metros de comprimento e delimitado por edifícios com alturas entre 3 e 13 pisos. Este espaço-corredor foi pensado inicialmente como espaço de estar e de encontro dos moradores, no entanto, depois de ocupado, transformou-se numa das zonas mais inseguras de Chelas, ficando conhecido como o corredor da morte, por nele se verificarem muitos atos de violência e criminalidade ${ }^{3}$. Essencialmente constituídos por habitação nos pisos superiores, estes edifícios têm nos pisos térreos comércio, serviços, equipamentos e arrecadações, sendo que a maioria está fechada e tem frentes cegas para o corredor central e para as ruas confinantes (Figuras 3 e 4). 
Figura $3 \triangleright$ Piso térreo para o corredor central. Bairro do Condado, Zona J, Marvila, Lisboa

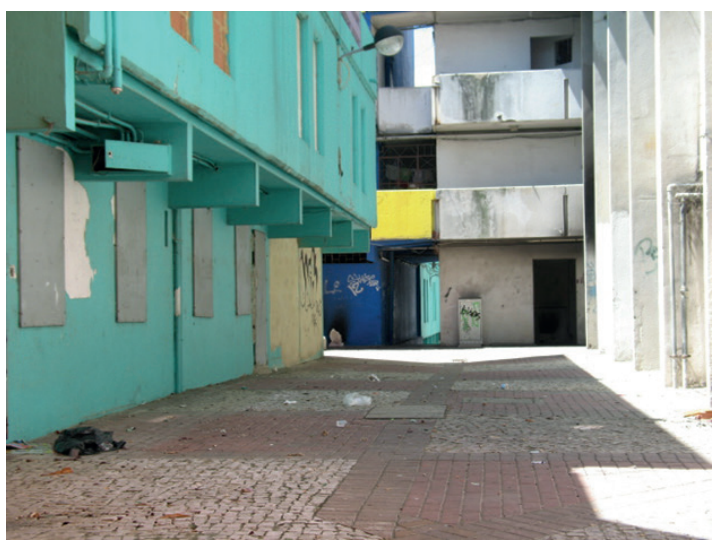

Fonte: Silva, 2011

Figura $4 \triangleright$ Piso térreo para a rua. Bairro do Condado, Zona J, Marvila, Lisboa

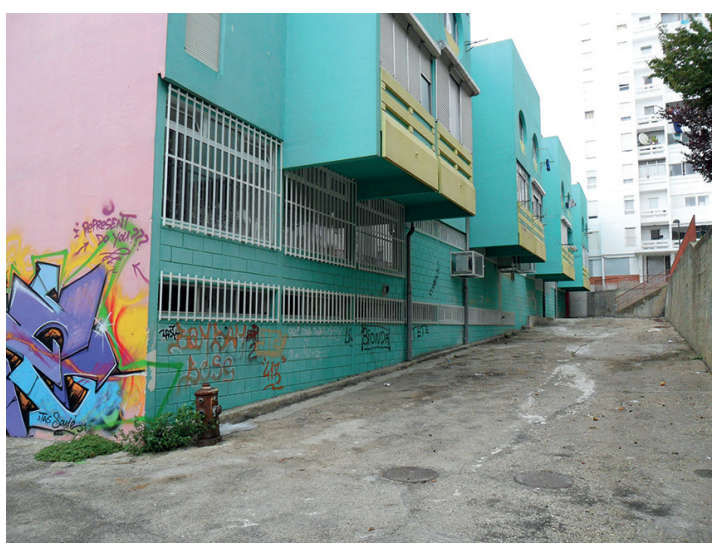

Fonte: Silva, 2011

Os edifícios apresentam dois tipos de estrutura: um, do tipo linear, que se desenvolve numa sequência de galerias, com fogos tipo dúplex, de 3 a 9 pisos, e onde o acesso aos lotes se faz a partir da rua através de módulos verticais (escadas e elevadores, ou só escadas), que acedem às galerias e estas às entradas dos fogos (Figura 5).

Outro, do tipo torre, com 13 pisos e 6 fogos por piso, perfazendo 71 fogos cada. Cada piso é composto por 2 T2 e 4 T3 que se organizam à volta de uma galeria aberta para um saguão central que percorre todos os pisos, acentuando a verticalidade do conjunto. Para a galeria abrem-se as entradas dos fogos e os acessos verticais (as caixas de escadas, 2 por torre, e os elevadores, 3 por torre) (Figura 6).

Bairro dos Lóios (Pantera Cor-de-Rosa). Os edifícios do bairro dos Lóios, projetados pelos arquitetos Gonçalo Byrne e António Reis Cabrita, têm como atuais proprietários o IHRU e alguns privados (moradores que adquiram as habitações onde residiam). Os edifícios de 4 a 8 pisos organizam-se em galerias: dois corpos paralelos criam um espaço público com alguma privacidade (Figura 7), outros organizam-se formando uma praça quadrada (a Praça Raul Lino), onde a atividade comercial e de serviços aí instalada cria uma centralidade no conjunto do bairro (Figura 8 ).

Os edifícios são constituídos por unidades de habitação (fogos simples ou dúplex) nos pisos superiores, e por comércio, serviços ou arrecadações (algumas delas encerradas e apropriadas para uso habitacional) nos pisos térreos. As pontes entre blocos, elementos característicos deste conjunto, têm como objetivo reduzir o número de acessos verticais (escadas e elevadores).

\section{Metodologia do estudo}

Em termos metodológicos, o estudo realizou-se a partir de três fases de trabalho: o levantamento do edificado, o diagnóstico das necessidades de intervenção e os cenários de intervenção ${ }^{4}$.

O levantamento teve, na sua origem, a recolha e o tratamento da informação disponível. Num pri-

Figura $5 \triangleright$ Estrutura linear (lotes em galeria). Bairro do Condado, Zona J, Marvila, Lisboa

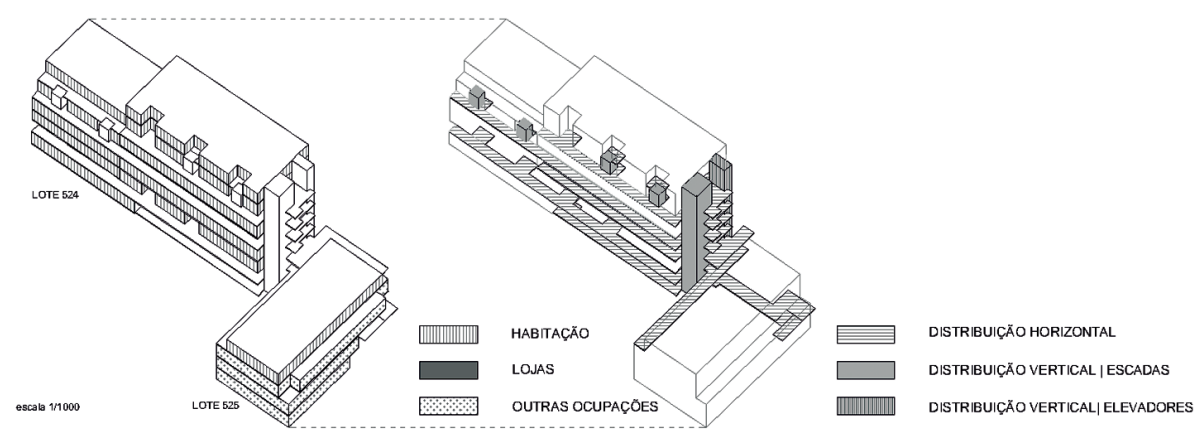

Fonte: Silva, 2011 
Figura $6 \triangleright$ Estrutura em torre. Bairro do Condado, Zona J, Marvila, Lisboa
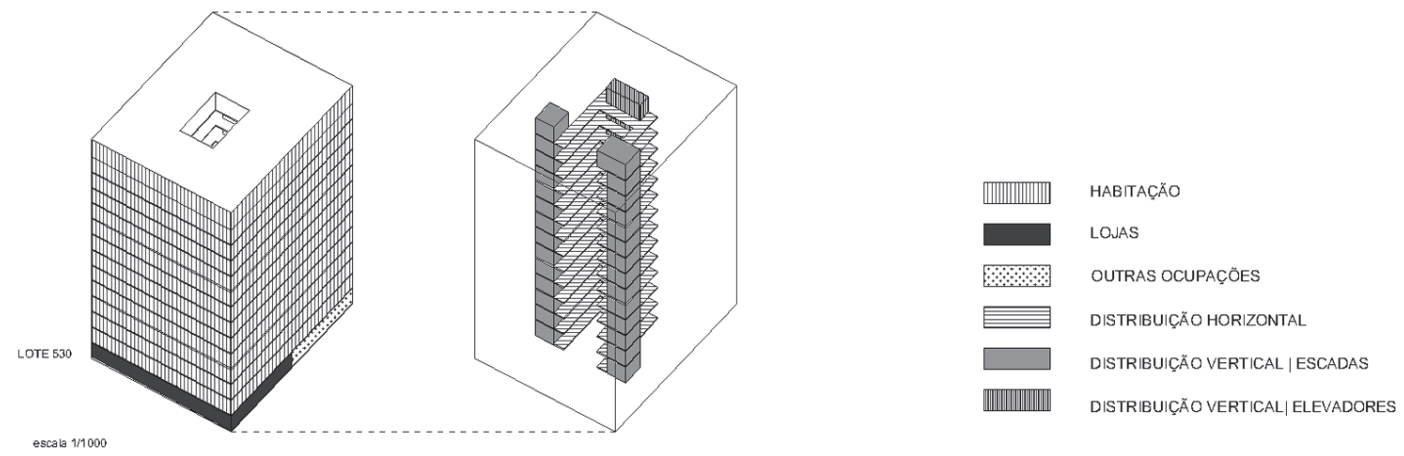

Fonte: Silva, 2011

Figura $7 \downarrow$ Estrutura linear (lotes em galeria). Bairro dos Lóios, Pantera Cor-de-Rosa, Marvila, Lisboa

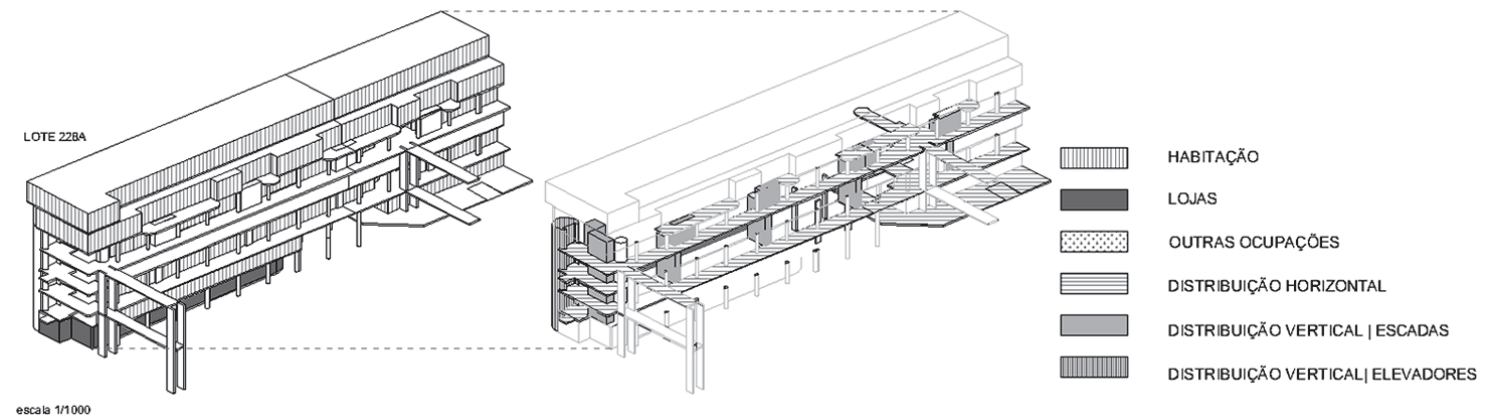

Fonte: Silva, 2011

Figura 8. Estrutura da praça. Bairro dos Lóios, Pantera Cor-de-Rosa, Marvila, Lisboa

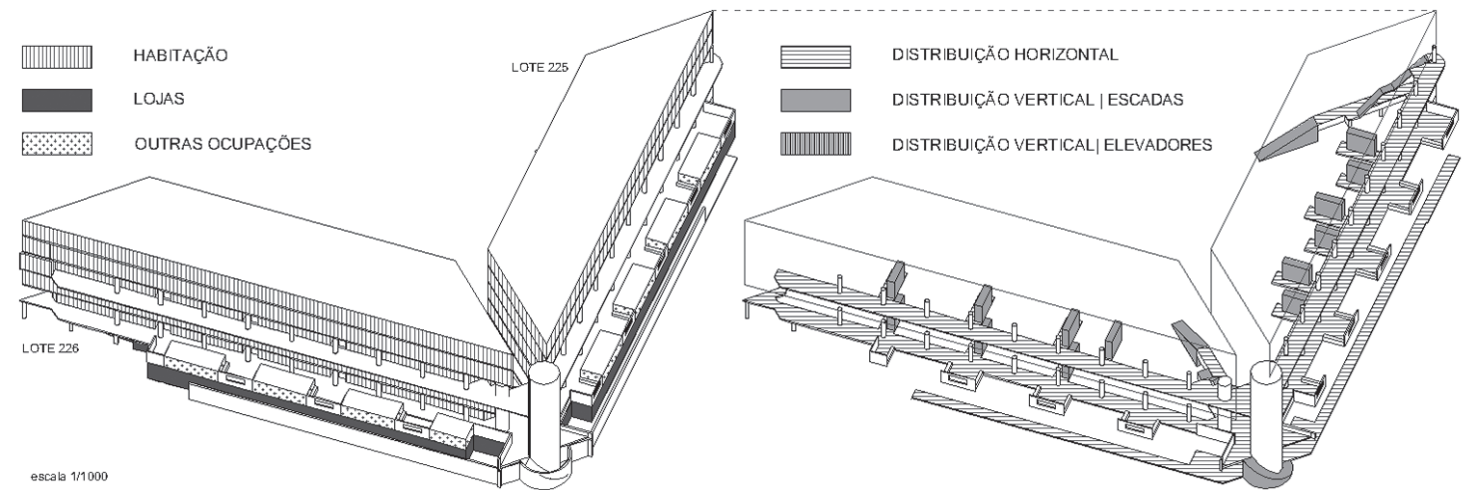

Fonte: Silva, 2011

meiro momento, os projetos originais serviram para atualizar a informação recolhida. Em colaboração com o gabinete Viver Marvila acedemos aos originais dos projetos de arquitetura: em papel (da Zona J) e, em formato digital (da Pantera Cor-de-Rosa), cedido pelo Arquivo do Forte de Sacavém. Esta documen- tação serviu para a produção de peças gráficas que subsidiaram todo o trabalho de campo. Nesta fase, realizaram-se reuniões alargadas com os serviços do IHRU e com a sua equipa técnica do Programa Viver Marvila, localizada em Chelas. Procedeu-se à recolha de dados, em relação ao regime de pro- 
priedade, às atividades, ao tipo de ocupação, às associações, etc. Realizaram-se igualmente reuniões com diversos agentes e parceiros locais no sentido de perceber o tipo de vivência do bairro. Na fase de levantamento produziram-se peças gráficas de todos os edifícios por piso (plantas e cortes) em formato digital (Figura 9).

Figura $9 \triangleright$ Levantamento. Planta do piso 0. Bairro dos Lóios, Pantera Cor-de-Rosa, Marvila, Lisboa

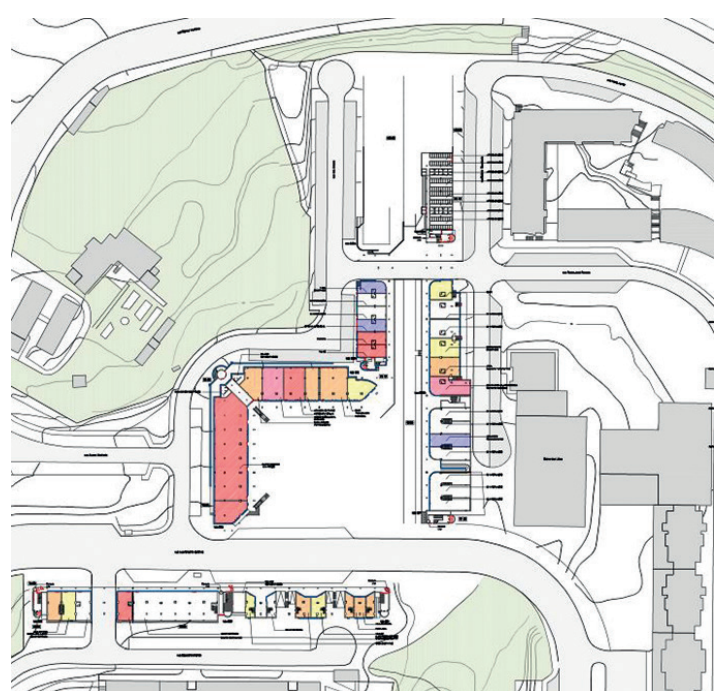

Fonte: Silva, 2011

O diagnóstico consistiu na realização de fichas, onde foram registadas as informações complementares ao levantamento e à descrição dos edifícios. Dado que 0 acesso aos lotes se faz, maioritariamente, através de serventias partilhadas, designámos por unidades funcionais os lotes, ou conjuntos de lotes, que dependem dos mesmos acessos, ou seja, parti-
Iham as mesmas escadas, percursos de circulação, elevadores, etc. (Figura 10).

Encontramos 22 unidades funcionais no bairro do Condado (Figura 11).

E 9 unidades funcionais no Bairro dos Lóios (Figura 12).

Figura $11 \triangleright$ Planta de localização e delimitação das unidades funcionais. Bairro do Condado, Zona J, Marvila, Lisboa

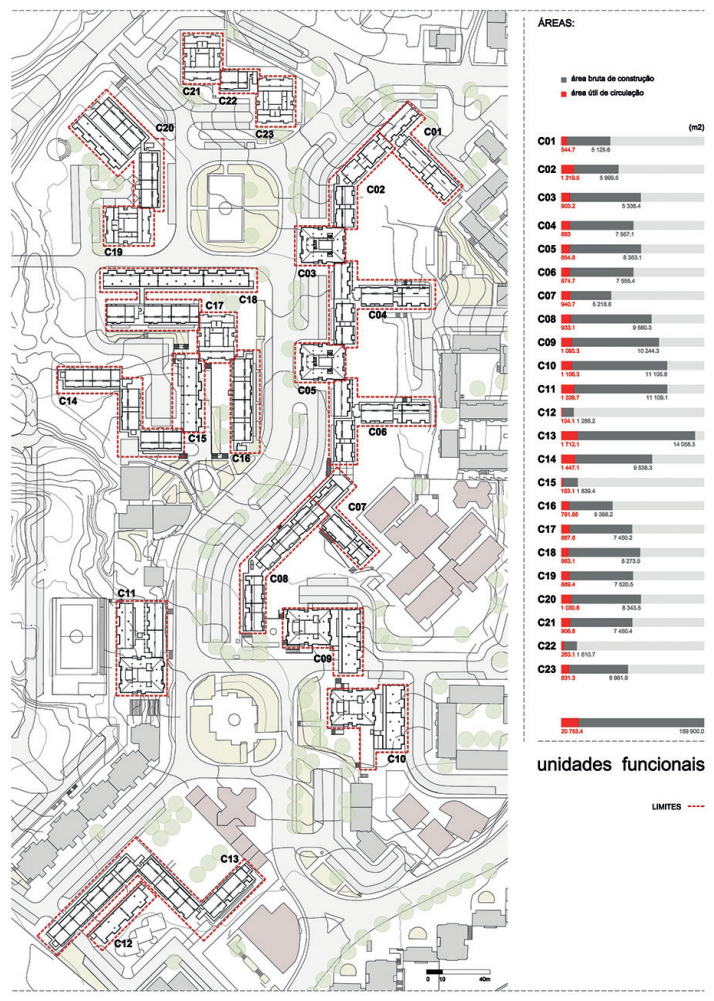

Fonte: Silva, 2011, cf. https://www.google.pt/maps

Figura $10 \triangleright$ Exemplo de uma unidade funcional com três lotes dependendo da mesma caixa de escada e elevadores. Bairro do Condado, Zona J, Marvila, Lisboa

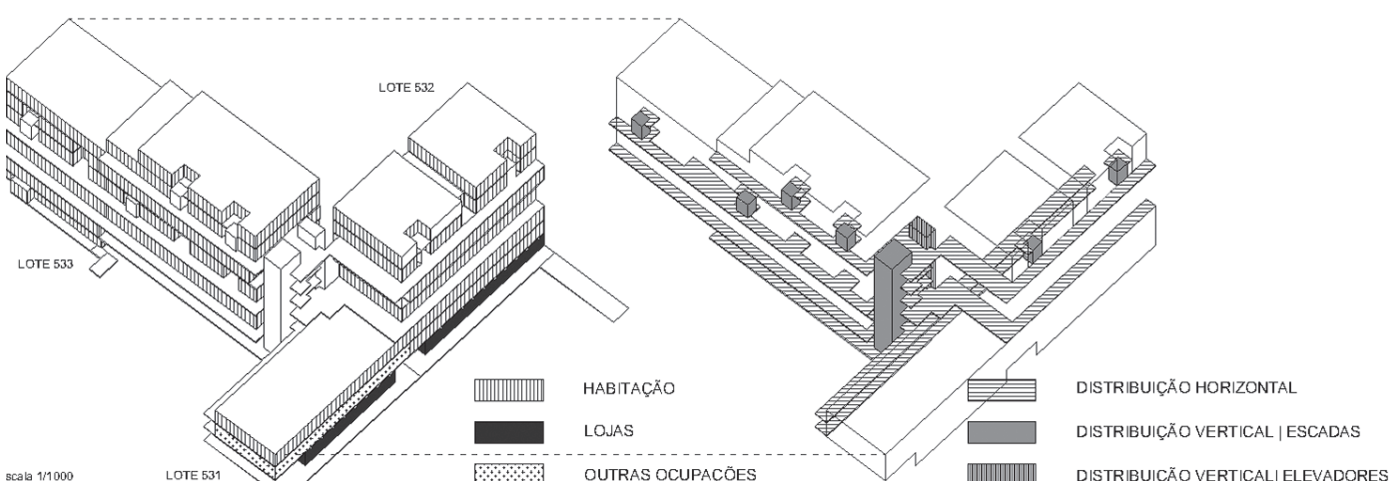

Fonte: Silva, 2011 
Figura $12 \downarrow$ Planta de localização e delimitação das unidades funcionais. Bairro dos Lóios, Pantera Cor-de-Rosa, Marvila, Lisboa

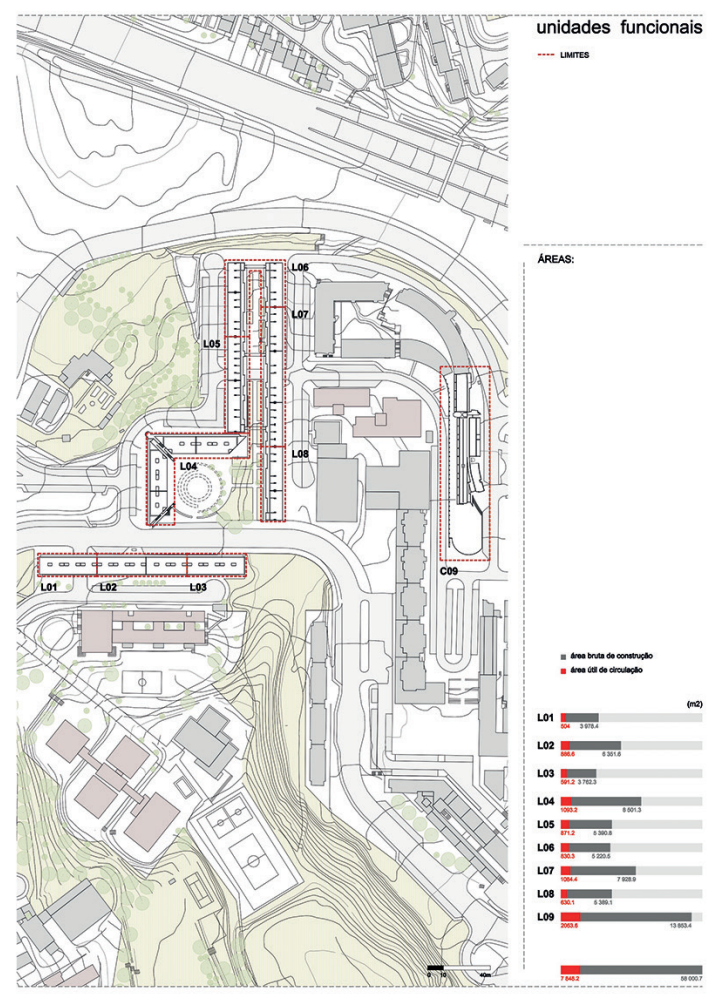

Fonte: Silva, 2011

As fichas de diagnóstico informam-nos acerca da localização das unidades funcionais, do número de lotes, do número de pisos, do número de circulações verticais, dos valores de proximidade, das tipologias, dos acessos, dos espaços intermédios (acessos, halls, pátios, galerias, corredores, terraços, etc. ), do tipo de usos (habitação, comércio, serviços, restauração, lazer, etc.), da composição construtiva, das patologias estruturais, da acessibilidade às redes, da situação geográfica, da forma de assentamento no terreno, do tipo de proteção solar dos vãos, do aproveitamento passivo de energia, da segurança contra incêndios, da gestão dos edifícios e da produtividade (Figuras 13 e 14).

Em todas as fases do trabalho, realizaram-se visitas aos bairros e envolvente próxima, com as equipas de técnicos do IHRU e do programa Viver Marvila.

\section{Discussão}

A partir do diagnóstico, dividimos a nossa discussão em três pontos: o primeiro é sobre a relação bairro/cidade, o segundo sobre a relação edifício/ /espaço público, e o terceiro sobre os espaços nem-nem (espaços comuns no interior dos edifícios).
Sobre a relação bairro/cidade. Observámos que estes bairros servem apenas os seus habitantes e utilizadores, e raramente são atravessados por terceiros, constituindo-se como um impasse social. Esta não transversalidade urbana/social/viária reforça a noção de que estes bairros são "ilha urbana", ou aquilo que Jane Jacobs designa como "zona de fronteira de uso único" (Jacobs, 2007, p. 287).

Encontrámos um desenho de implantação dos conjuntos residenciais com uma leitura clara do território, empregando os princípios do modernismo (Figura 15), no entanto, esta é adversa à ideia de continuidade com a envolvente rural (e de lazer), que acontece de forma desorganizada, por apropriação de baldios, não tendo em vista os interesses dos residentes.

Sobre a relação edifício/espaço público. Verificámos que nestes edifícios os pisos térreos (à exceção das entradas dos lotes), na sua maioria, se encontram encerrados porque ou são habitações, ou arrecadações, ou estão abandonados, constituindo barreiras entre a rua e o edifício, dificultando o seu bom funcionamento. Também encontrámos vários elementos construídos (muros, escadas, paredes cegas, etc.), que dificultam a leitura e o controlo do espaço público por não terem um desenho claro (Figuras 3 e 4).

Sobre os espaços nem-nem. Observámos que estes espaços são o suporte físico de acesso às habitações e assumem especial relevância, porque organizam o edifício. Como espaços comuns, é aqui que se dá o primeiro contacto entre os moradores e os visitantes, é onde se verifica o estabelecimento de relações de vizinhança, e o estabelecimento de relações de pertença entre a rua e o espaço privado da habitação. A separação entre a casa (espaço privado) e a rua (o espaço público) é feita através destes espaços aqui designados de nem-nem (nem são públicos nem são privados), que intermedeiam o domínio público e o domínio privado onde vários lotes partilham os mesmos percursos de circulação, as mesmas escadas, galerias, elevadores, acessos, etc. Estes espaços de transição são espaços de uso coletivo e livre acessibilidade, existem no interior dos edifícios e servem para promover a transição entre os domínios público e privado (Heitor, 2001). Dos 43 lotes estudados do Condado e dos 9 lotes estudados nos Lóios, apenas 11 e 5, respetivamente, funcionam de forma isolada, sendo que os restantes partilham núcleos de acessos (escadas, galerias e elevadores). É de notar que estes espaços constituem percursos de fuga em caso de incêndio, apesar de não terem as dimensões das unidades de passagem desejáveis, nem as situações de impasse cumprirem as distâncias desejáveis às circulações verticais (Figura 16). O registo médio de distância máxima até às circulações verticais, em situação de impasse, no Condado é de 44,2 m 
Figura $13 \triangleright$ Ficha de diagnóstico da unidade funcional C08. Bairro do Condado, Zona J, Marvila, Lisboa

\section{C.08}

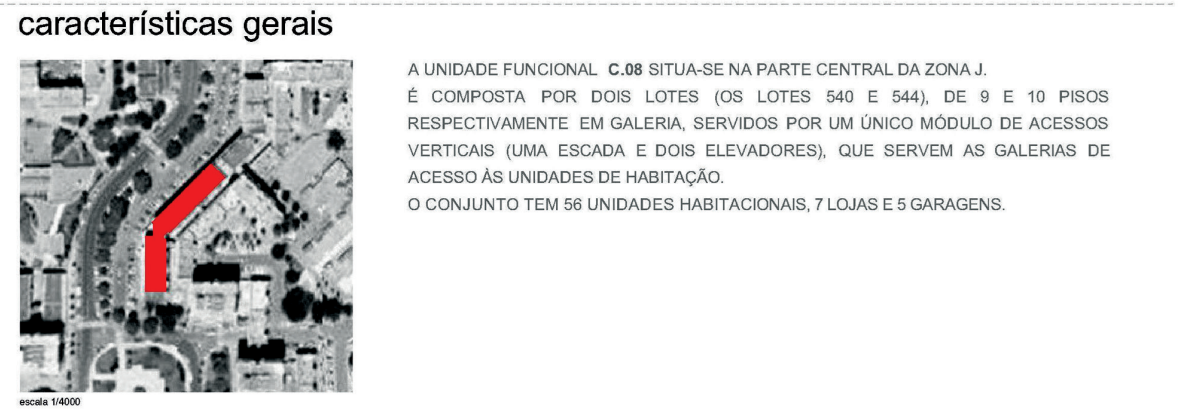

valores de proximidade

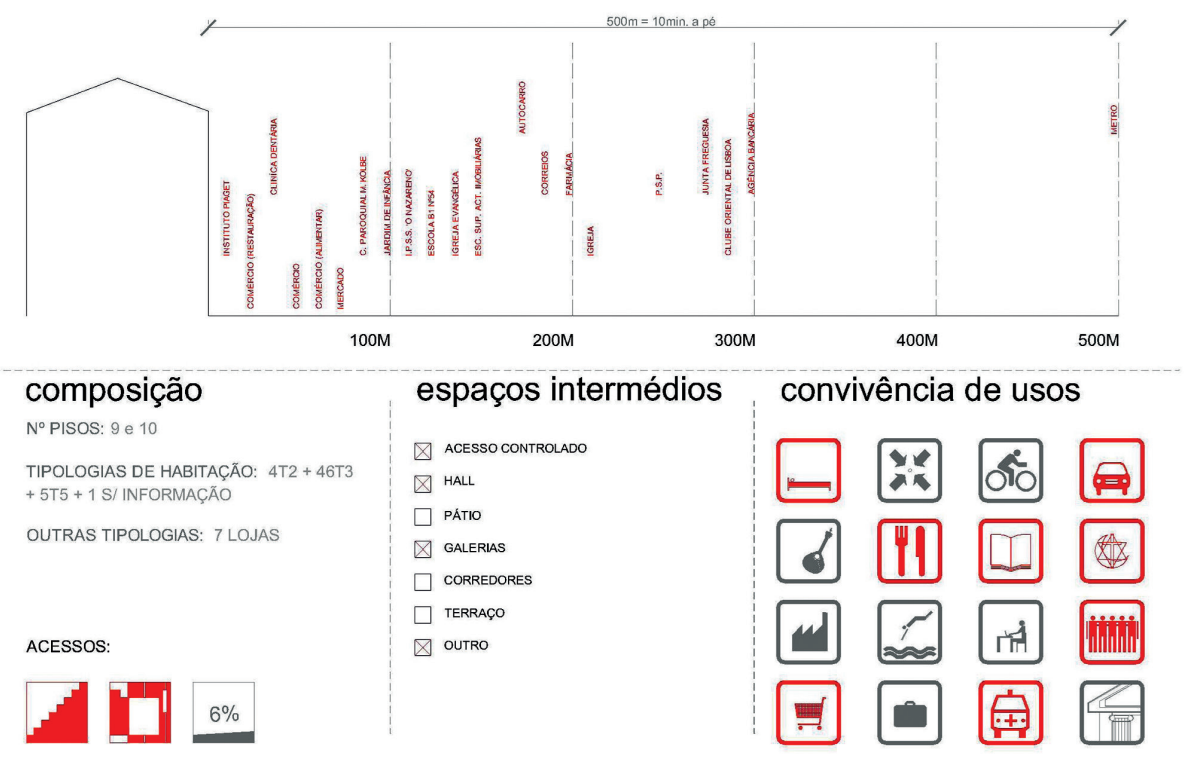

Fonte: Silva, 2011

e nos Lóios de 53,5 m. A distância máxima até à circulação vertical registada no Condado é $88,9 \mathrm{~m}$ e nos Lóios de $81,7 \mathrm{~m}^{5}$.

Nas entradas, o mau funcionamento dos trincos e a ausência de campainhas levam a que a "porta da rua" esteja por regra aberta, tornando o espaço de hall um contínuo espaço de ninguém que só parece acabar ou na porta de casa, ou em formas espontâneas de controlo, através da colocação de portões e grades.

\section{Conclusão}

Os condicionalismos do território, consequência da topografia e do desenho do traçado, manifestam- -se na dispersão e no isolamento dos conjuntos habitacionais no território que, consequentemente, originam uma fraca relação entre eles. Este facto propicia, por um lado, a exclusão social e o isolamento dos seus habitantes em relação ao resto da cidade, e, por outro, a dificuldade de aceder aos serviços e equipamentos fora do bairro.

O facto de não existir uma hierarquia definida entre espaços públicos, semipúblicos e privados, assim como o facto de se verificar uma indefinição entre esses espaços (públicos e privados), conduz à existência de espaços anónimos ou impessoais, cuja utilização é pouco clara, dificultando a sua apropriação de forma adequada pela população que neles habita. Esses espaços anónimos são por 
Figura $14 \triangleright$ Ficha de diagnóstico da unidade funcional C08 (continuação). Bairro do Condado, Zona J, Marvila, Lisboa

\section{C.08}

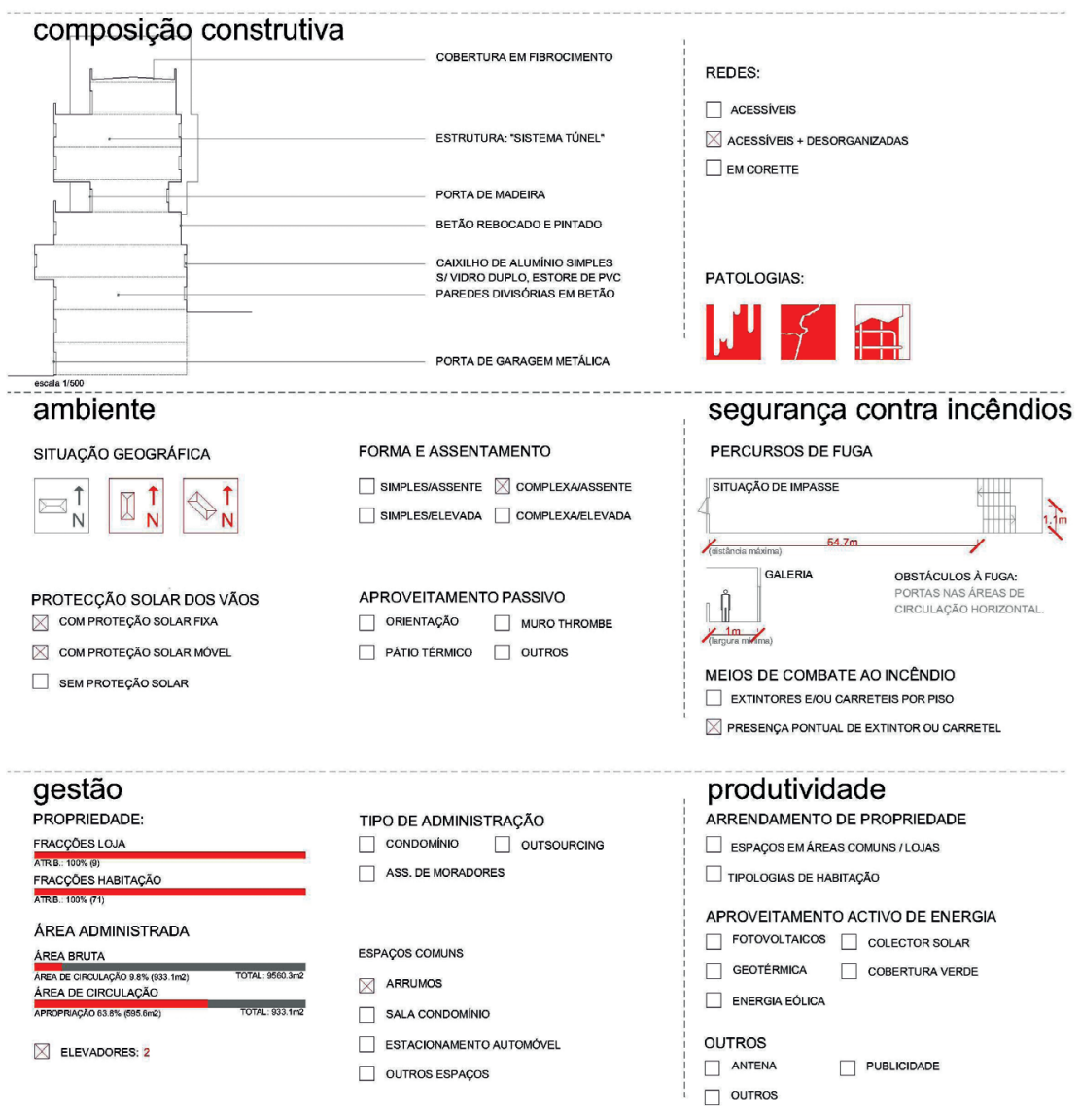

Fonte: Silva, 2011

Figura $15 \triangleright$ Relação bairro/cidade. Bairro do Condado e bairro dos Lóios, Marvila, Lisboa

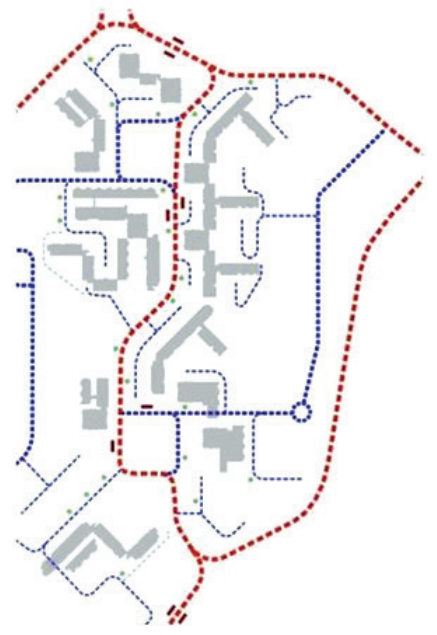

- lixolecoponto

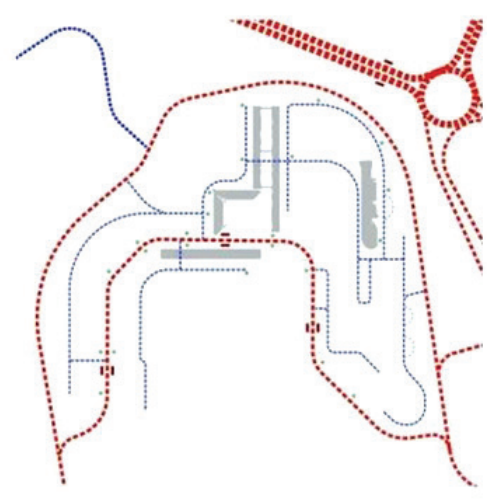

-.. paragem bus

..... eixo principa

Fonte: Silva, 2011 
Figura $16 \triangleright$ Indicação dos espaços de percurso de fuga. Bairro do Condado, Zona J, Marvila, Lisboa

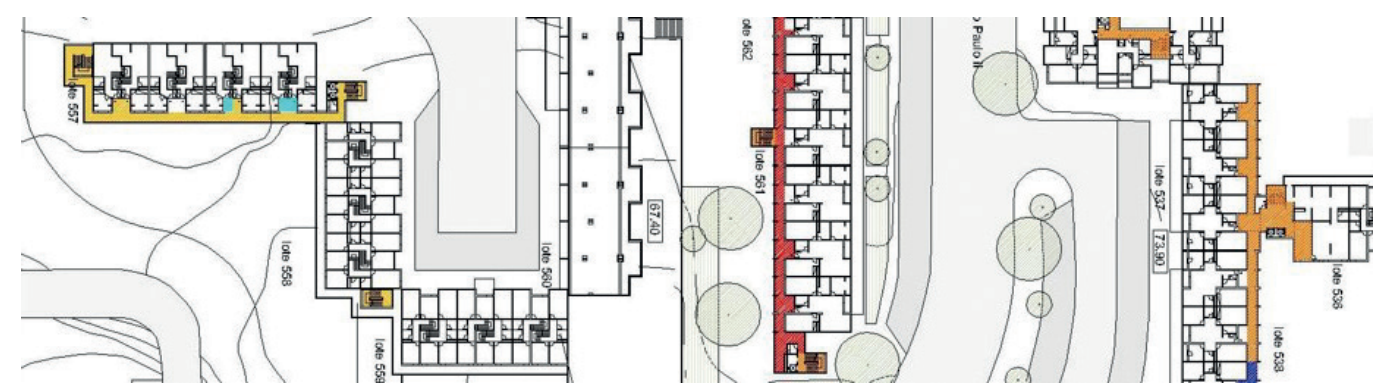

Fonte: Silva, 2011

Figuras 17 e $18 \triangleright$ Controlos do espaço nas galerias. Bairro do Condado, Zona J, e bairro dos Lóios, Pantera Cor-de-Rosa, Marvila, Lisboa
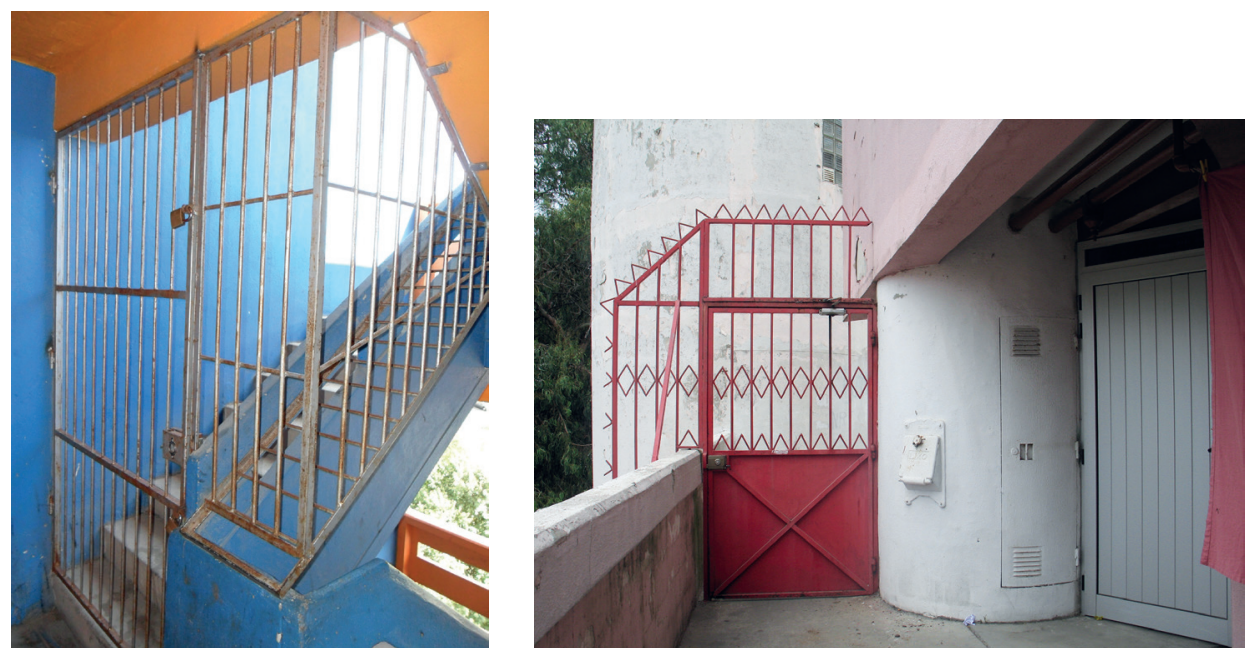

Fonte: Silva, 2011

Figuras 19 e $20 \triangleright$ Utilização das galerias. Bairro do Condado, Zona J, Marvila, Lisboa
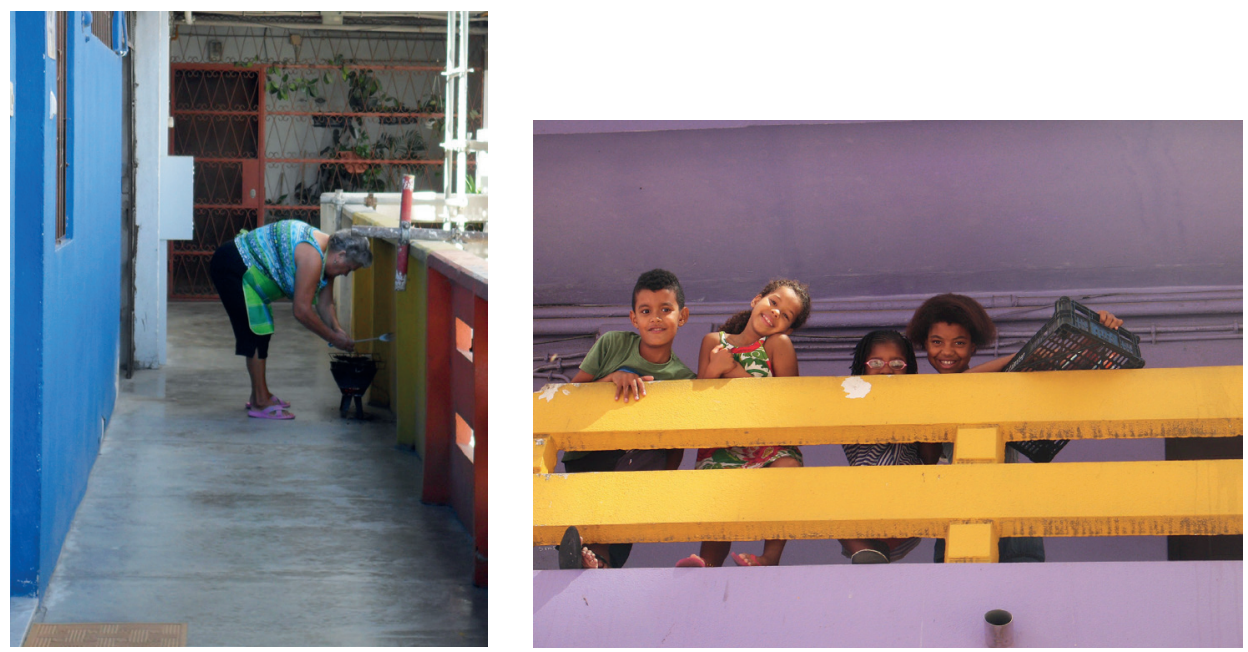

Fonte: Silva, 2011

\section{E Sociológico}

N. 034 (II Série, 2019)
pp. 31-42 
isso abandonados, entrando num avançado estado de degradação e deterioração, ou apropriados por vezes de forma ilegal. Assim, a existência de espaços de transição, aqui designados de nem-nem por não terem um carácter nem público nem privado e por serem partilhados entre habitantes de diferentes lotes, traz consequências positivas e negativas para os seus habitantes. Se, por um lado, é propício ao estabelecimento de relações de pertença pela apropriação por parte dos seus moradores, é também motivo e área de conflito entre moradores de diferentes lotes. A apropriação desses espaços comuns de forma desadequada, como seja, encerrando as passagens no interior dos conjuntos edificados, traz situações de difícil gestão como o corte dos percursos de fuga em caso de incêndio e/ou catástrofe, a difícil administração das redes de infraestruturas (água, eletricidade, gás, etc.), a multiplicação de obstáculos às pessoas com mobilidade reduzida e a apropriação ilegal das áreas comuns. A gestão destes conjuntos torna-se difícil, devido à deficiente definição dos limites dos lotes, não permitindo o convencional funcionamento e gestão lote a lote, uma vez que esses espaços não pertencem a um lote, mas a um conjunto de lotes.

\section{Notas}

1 Designámos "espaços nem-nem" que, nem são públicos nem são privados, por analogia com o termo "nem-nem" (de "nem trabalha, nem estuda") aceite para designar a população jovem fora do mercado de trabalho e de instituições educacionais. (Fonte: https://pt. wikipedia. org/wiki/Nem-nem).

2 O estudo foi realizado por uma equipa do ISCTE-IUL, Instituto Universitário de Lisboa, em 2011, tendo sido a equipa selecionada a partir de um concurso por convite promovido pelo IHRU (Instituto de Habitação e Reabilitação Urbana). Equipa: Arquitetura: Teresa Madeira da Silva, Pedro Marques Alves, Miguel Vasconcelos Magalhães, Maria João Oliveira. Colaborador: Samuel Dias. Consultores: Pedro Viana Botelho e Pedro Mendes. Fundações e Estruturas: Fernando Rodrigues. Gestão Energética: Vasco Moreira Rato. Redes e Segurança Integrada: Joaquim Nogueira. Economia, Gestão Urbana e Gestão do Património: Pedro Costa. Coordenação: Teresa Madeira da Silva.

3 Atualmente esse corredor já não existe, porque seis lotes foram demolidos, permitindo que o mesmo se tornasse mais permeável, acessível, visível da rua e, por isso, mais seguro.

4 Não iremos mencionar os cenários de intervenção propostos no estudo por considerarmos que não cabem no âmbito deste artigo.

5 Note-se que o Decreto-Lei n. ${ }^{\circ}$ 220/2008, de 12 de novembro, que aprovou o regime jurídico de segurança contra incêndio, determina que, no caso de edifícios deste tipo, a distância máxima a percorrer nos locais de permanência em edifícios até ser atingida a saída mais próxima, para o exterior ou para uma via de evacuação protegida, deve ser de $15 \mathrm{~m}$ nos pontos em impasse.

\section{Referências bibliográficas}

Bristol, K. (1991). The Pruitt-Igoe Myth. Journal of Architectural Education, 44(3), 163-171.

Cabrita, A. R. (1981). Conjunto habitacional em Chelas: Zona 2. Revista Arquitectura, 4(140), 19-29.

Decreto-Lei n. 0 220/2008 de 12 de novembro. Diário da República n.o 250/2008 - Série I. Lisboa: Ministério da Administração Interna

Ferreira, A. F., Guerra, I., \& Freitas, M. J. (Coords.) (1994). Dossier "As pessoas não são coisas que se ponham em gavetas". Sociedade e Território, 20.

Guerra, I. (1994). As pessoas não são coisas que se ponham em gavetas. Sociedade e Território, 20, 11-16.

Guerra, I., Pereira, S. M., Fernandes, M., Botelho, P., \& Marques, P. (2008). Contributos para o Plano Estratégico de Habitação 2008/2013 - Documento Políticas Urbanas. Lisboa: CET/ISCTE. Retirado de http://habitacao.cm-lisboa.pt/documentos/1234 211200I5eGS7kj9Fq51IF7.pdf

Heitor, T. V. (2001). A Vulnerabilidade do Espaço em Chelas. Uma Abordagem Sintáctica. Lisboa: FCG e FCT.

Heitor, T. V. (s. d.). Olivais e Chelas: Operações urbanísticas de grande escala. Acessível em: https: // www.academia.edu/30782326/Olivais_e_Chelas_ Opera\%C3\%A7\%C3\%B5es_Urban\%C3\%ADsticas_ De_Grande_Escala

Hertzberger, H. (1996). Lições de Arquitetura. São Paulo: Martins Fontes.

IHRU (s. d.). Portal da Habitação. Acessível em: http://www.portaldahabitacao.pt/pt/portal/ glossario.

Iniciativa Bairros Críticos, Operação Vale da Amoreira, Diagnóstico (2006). Vale da Amoreira: GAT.

Jacobs, J. (2007). Morte e Vida de Grandes Cidades. São Paulo: Martins Fontes.

Lamas, J. R. G. (s. d.). Morfologia Urbana e Desenho da Cidade. Lisboa: Fundação Calouste Gulbenkian - Junta Nacional de Investigação Científica e Tecnológica.

Lynch, K. (1988). A Imagem da Cidade. Lisboa: Edições 70.

Malheiros, J., Vasconcelos, L., \& Alves, F. S. (Coords.) (2006). Operação Cova da Moura, Iniciativa Operação de Qualificação e inserção Urbana em Bairros Críticos, Volume I - Diagnóstico, Lisboa.

Marques, T. S. (Coord.) (s. d.). Operação Lagarteiro. Lagarteiro - Uma intervenção alicerçada na participação. Lisboa.

Montaner, J. M., \& Martinez, Z. M. (2006). Habitar el Presente. Vivienda en España: Sociedad, Ciudad, Tecnología y Recursos. Madrid: Ministerio de Vivienda.

Monteys, X., \& Fuertes, P. (2001). Casa collage: un ensayo sobre la arquitectura de la casa. Barcelona: Editorial Gustavo Gili, SL. 
Pereira, L. V., Gago, M. A. C., \& Lopes, M. J. (1984). Inquérito à Habitação Urbana. Lisboa: LNEC.

Santos, C. N. F. dos, \& Vogel, A. (1985). Quando a rua vira casa: A apropriação de espaços de uso coletivo em um centro de bairro. São Paulo: Projeto.

Silva, T. M. da (Coord.) (2011). Relatório Final. Estudo de Avaliação e Diagnóstico das Necessidades de Intervenção em Edifícios nos Bairros do Condado e dos Lóios em Marvila. Lisboa: ISCTE-IUL.
Silva, T. M. da, Alves, P. M., Magalhães M. V., \& Oliveira, M. J. (2011a). Recuperação do Património Recente: Dois Bairros de Intervenção Prioritária na Periferia de Lisboa. In Atas da Conferência Internacional - Portugal entre desassossegos e desafios. Coimbra: CES, Centro de Estudos Sociais da Universidade de Coimbra.

Silva, T. M. da, Alves, P. M., Magalhães M. V., \& Oliveira, M. J., (2011b). Edifícios de Habitação Social: Diagnóstico e Cenários de Intervenção. CIDADES, Comunidades e Territórios, 22, 82-98.

Data de receção: 31/10/2018. Aceite para publicação a 26/02/2019

Teresa Madeira da Silva (teresa.madeira@iscte-iul.pt). Departamento de Arquitetura e Urbanismo / DINAMIA'CETIUL, Escola de Tecnologias e Arquitetura, Edifício ISCTE, Av. das Forças Armadas, 1649-026 Lisboa, Portugal 


\title{
NECESSIDADE, OPORTUNIDADE E ILEGALIDADE EM HABITAÇÃO - ALOJAMENTO LOCAL E TENDÊNCIAS CONTEMPORÂNEAS NEED, OPPORTUNITY AND ILLEGALITY IN HOUSING - SHORT-TERM RENTALS AND CONTEMPORARY TRENDS
}

\author{
Inês Calor \\ CEGOT - Departamento de Geografia da Universidade do Porto \\ Mateus Magarotto \\ - LEGECE - Departamento de Oceanografia da Universidade Federal de Pernambuco e CEGOT - Departamento de Geografia \\ da Universidade do Porto
}

\begin{abstract}
Resumo
O arrendamento de curta duração de habitação está num processo rápido de mudança para um novo paradigma setorial onde as plataformas online (como a Airbnb) têm um papel preponderante. A imposição de restrições à atividade faz parte da agenda social e política da maioria dos países europeus. Contudo, conforme demonstram as primeiras tentativas, regulamentar não é suficiente, visto os promotores ignorarem muitas vezes as regras impostas. A monitorização e a fiscalização acarretam grandes dificuldades para a administração pública.

Este artigo foca-se nas regras desenhadas para o alojamento local e no alcance das medidas implementadas em Portugal. Traça um esboço da ilegalidade urbanística nesta área na era da economia partilhada, abordando as estratégias de regulação e os resultados alcançados. A conclusão aponta para o facto de a verificação do cumprimento das obrigações legais de registo ou fiscais ser uma questão de justiça e responsabilidade social.
\end{abstract}

Palavras-chave: Airbnb; habitação; turismo

\begin{abstract}
Short-term housing rentals are in a rapid shift to a new sectorial paradigm where online platforms (such as Airbnb) play a significant role. The restrictions on the rentals of entire apartments are on the social and political agenda of most European countries. However, as the first attempts demonstrate, regulation is not enough, as owners often ignore it. The monitoring and enforcement of such rules entails great difficulties for public administrations.

This article focuses on the rules designed and measures for short-term rentals implemented in Portugal. It outlines the urbanistic illegalities in this field in the age of shared economy, addressing the regulatory strategies adopted and the results achieved. The conclusions point out that the compliance with registration and taxation rules is a matter of justice and social responsibility.
\end{abstract}

Keywords: Airbnb; housing; tourism

\section{Mudanças na cidade e na habitação}

O direito à habitação é consagrado pela Carta Universal dos Direitos Humanos e pela Constituição. Contudo, no contexto neoliberal, a habitação não é apenas um lugar para "habitar", mas sim um bem de consumo dinâmico e em constante mutação. As plataformas online têm um crescente impacto na sociedade e na vida urbana, permitindo a fácil ligação entre pessoas e a oferta do mais variado tipo de serviços. A chamada "economia de partilha" (de bens desaproveitados ou subaproveitados), das quais se 
tornaram ícones as plataformas Uber e Airbnb, veio alterar definitivamente as formas tradicionais de transporte, alojamento, turismo e, por consequência, a forma de habitar as cidades. Este crescimento da economia de partilha ou "economia da confiança" é defendido por muitos economistas como um novo paradigma económico e prevê-se que poderá vir ainda a alterar de forma substancial o setor de serviços (Dudás, Vida, Kovalcsik, \& Boros, 2017). Inserido nesta temática, o arrendamento de curta duração cresceu exponencialmente nos últimos anos, alavancado pela implementação de aplicações web que colocam a oferta de alojamentos de todo o mundo à distância de um clique. A última contagem da Airbnb indica a sua utilização por quase 300 milhões de hóspedes distribuídos por 191 países $^{1}$. O surgimento de outras plataformas online similares, como a HomeAway e a VRBO, revelam uma predisposição geral para a aceitação deste tipo de serviços e interação.

A facilidade de acesso dos utilizadores e a oferta de uma grande diversidade de alojamentos é hoje um fator importante na tomada de decisão de uma pessoa viajar ou de se hospedar em qualquer parte do mundo. Nos últimos anos, a implementação de plataformas de economia de partilha é levada a cabo por um processo de reestruturação da oferta de equipamentos, estruturas de lazer e habitação. As novas tecnologias, associadas a produtos turísticos, formam a base do conceito de unidades hoteleiras, como forma de valorização do seu modelo de negócio, mas também da criação competitiva de formas alternativas de alojamento (Munkøe, 2017). A valorização do modelo de negócio e a criação competitiva de alojamento estão cada vez mais segmentadas e influenciadas pelas alterações ao nível do consumidor, sobretudo na última década (Turismo de Portugal, 2007).

Volvidos poucos anos desde o seu surgimento, estas novas formas de hospedagem causaram um profundo impacto económico, social e urbano. Por um lado, criaram a oportunidade de proprietários singulares obterem rendimentos significativos (complementares à economia familiar ou a criação de postos de trabalho), fomentaram a tão necessária reabilitação urbana nos centros das cidades (Lopes, 2018) e proporcionaram o aumento da capacidade turística, contribuindo para o crescimento económico favorável.

Por outro lado, as externalidades negativas são fortemente contestadas: a concorrência à indústria hoteleira, a perturbação da tranquilidade e a segurança dos edifícios de habitação coletiva e, em especial, o aumento significativo do preço da habitação. Nas principais cidades portuguesas, a ausência de políticas públicas para habitação acessível, a alteração à Lei do Arrendamento e os programas de reabilitação urbana (Mendes, 2014) facilitaram o processo de gentrificação, promovendo a deslocação da população mais desfavorecida para fora do centro das cidades. Além destas inquietações, o princípio de "partilha" da Airbnb tem merecido crescentes ataques, perante a evidência de uma elevada percentagem da oferta de alojamentos ser referente a apartamentos inteiros, onde o anfitrião não está presente e a profissionalização dos serviços se aproxima dos serviços hoteleiros.

Por definição legal², a designação de alojamento local engloba os estabelecimentos "que prestem serviços de alojamento temporário a turistas, mediante remuneração" e que não "reúnam os requisitos para serem considerados empreendimentos turísticos". Apesar da distinção, são atividades naturalmente concorrentes. No entanto, estudos recentes mostram que o impacto da presença do alojamento local no sector hoteleiro tem sido moderado, sendo mantidos os níveis de lucro da maioria dos hotéis mas trazendo dificuldades aos estabelecimentos voltados para o segmento mais económico (AHRESP, 2016). Os reflexos do alojamento local no aumento do preço da habitação tendem a ser também desvalorizados na literatura académica, sendo as causas do aumento dos preços apontada à conjugação de vários fatores, dos quais se destaca o incentivo ao investimento estrangeiro (Lopes, 2018). No entanto, o aumento do preço da habitação é encarado como o problema atual mais premente do ponto de vista urbanístico, social e habitacional.

Em Portugal é especialmente preocupante a escalada do preço de venda de habitação, estimado em 20\% entre 2015 e 2017 (INE, 2017). Este período de florescimento do alojamento local é exacerbado pela relativa facilidade na obtenção de crédito. 0 valor médio dos novos empréstimos aproxima-se dos 100 mil euros, montante mais elevado desde janeiro de 2009, período antes do início da crise (INE, 2017). Por outro lado, o arrendamento de longa duração (historicamente com pouca expressão em Portugal) sofre uma escassez crónica de oferta e subida desproporcionada nos preços. Depois de décadas de congelamento de rendas, os desalojamentos sucedem-se e os apartamentos disponíveis no centro das principais cidades são destinados a outros fins.

A valorização exacerbada dos imóveis no centro das grandes cidades não é um problema novo, sendo o progressivo esvaziamento a favor das atividades comerciais e de serviços um problema reconhecido há décadas (Mendes, 2014). Contudo, o fenómeno do alojamento local tem a capacidade de exercer influência numa área geograficamente muito mais alargada e, sobretudo, a velocidade da mudança em curso não tem precedentes. Por isso, a (sobre)valorização da função habitacional é, nestes níveis, um problema novo e de grande impacto para as cidades.

A administração nacional e a administração local têm hoje um dilema em mãos, na forma de regular 
esta nova atividade. O processo de "turistificação" do centro das cidades parece ser irreversível. A intervenção do estado e a imposição de restrições ao arrendamento de apartamentos inteiros faz parte da agenda social e política atual na maioria dos países europeus (Dudás et al., 2017). Contudo, conforme demonstram as primeiras tentativas de desenhar medidas regulamentares, não é suficiente para que estas atinjam efeitos práticos. Perante a magnitude dos interesses e lucros em perspetiva, a tendência dos promotores é ignorar as restrições impostas. A monitorização e a fiscalização das regras desenhadas até ao momento acarretam grandes dificuldades de ordem prática para a maioria das entidades da administração.

Nesse sentido, este artigo pretende focar-se nas questões atinentes aos problemas da monitorização e fiscalização das regras desenhadas para o alojamento local, abordando o alcance das medidas implementadas até ao momento em Portugal. Estruturado em dois capítulos centrais, em primeira instância, este ensaio traça um esboço daquilo que é a informalidade na era da economia partilhada e, em segunda instância, aborda as estratégias de regulação adotadas e os resultados alcançados.

\section{A informalidade na era da economia partilhada}

A necessidade de habitação primária é legitimamente entendida como o principal argumento para o surgimento de bairros de lata, loteamentos ilegais e habitações "marginais". Esta perspetiva é especialmente acolhida em países em desenvolvimento e em outros países mais desenvolvidos, com maior enfoque numa camada social desfavorecida. Contudo, a ilegalidade urbanística não se consubstancia apenas neste contexto de necessidade. Ainda que com diferentes características, mesmo nos países mais desenvolvidos, os exemplos de ilegalidade urbanística são variados (Calor, 2017; Calor \& Alterman, 2017). Exemplos mediáticos de habitações ilegais (ou semilegais) podem ser encontrados em Inglaterra ou no Canadá. Em Portugal, um estudo realizado com base nos dados do INE aponta para a existência de mais de 282000 edificações ilegais construídas entre 1991 e 2011 (Calor, 2017). À semelhança de Portugal, noutros países mediterrâneos como a Grécia e Espanha os proprietários são audazes e a administração incapaz de lidar com o elevado número de infrações urbanísticas.

Perante este panorama, poderemos esperar que os promotores do alojamento local cumpram com as regras urbanísticas estabelecidas no momento e para o futuro? Importa realçar que os promotores do alojamento local não partem de uma "necessidade" de habitação própria, situando-se antes entre uma classe média com capital e habitação própria.
A delimitação dos conceitos de "habitação primária", "habitação secundária" e "alojamento turístico" são cada vez mais difíceis de traçar. Perante a possibilidade de rentabilização pecuniária, as mudanças no tecido habitacional são rápidas, profundas e com uma certa tendência para ignorar as regras estabelecidas. Estará o sistema de planeamento urbanístico preparado para a mudança de paradigma?

Devido às externalidades negativas, a sociedade e a opinião pública apelam por medidas que regulem a atividade de alojamento local. Restrições têm vindo a surgir em vários países e cidades com elevada presença e impacto do alojamento de curta duração. As estratégias são variadas. Em Londres é aplicado o limite de 90 dias ao arrendamento por particulares, salvo quando o proprietário obtenha uma licença urbanística para propriedade de arrendamento para férias. Em São Francisco (EUA), o limite é de 30 dias (Ferreri \& Sanyal, 2018; Gregory \& Halff, 2017; Martin, 2016). Já em Berlim, casas inteiras devem ser registadas e taxadas como casas de férias, tendo menos restrições o arrendamento de quartos na presença do anfitrião. Em Barcelona, o número de apartamentos foi restringido por áreas, através de zonamento específico (Segú, 2018). Numa atitude mais extremada, Nova Iorque atualizou recentemente as suas leis para banir a publicitação de alugueres de curta duração (Dudás et al., 2017; Gurran, 2017).

Contudo, a simples criação de regras não é garantia suficiente da implementação efetiva das restrições, e a administração debate-se com grandes dificuldades em fazer cumprir as regras. A atividade do alojamento local nem sempre é feita com a boa-fé dos proprietários e das suas responsabilidades perante as normas e regras implementadas, geralmente destinadas a diminuir as disparidades entre 0 arrendamento tradicional e o novo paradigma oferecido por plataformas online. A alta rentabilidade do setor fomenta soluções imaginativas. A pluralidade de anfitriões e a possibilidade de lucro faz aumentar a tendência para contornar as regras estabelecidas e alguns exemplos nitidamente "informais" podem ser encontrados nas plataformas online. Por preços vantajosos e abaixo dos valores de mercado é disponibilizada, por exemplo, uma garagem-bar com casa de banho no "arbusto mais próximo" em Praga, na República Checa, em $2015^{3}$ (Figura 1) ou uma caravana estacionada no centro de Nova Iorque com utilização das instalações sanitárias no ginásio próximo, em $2018^{4}$ (Figura 2). No entanto, na maioria dos casos, não é possível a "olho nu" identificar claramente a qualidade (e legalidade) dos alojamentos disponibilizados.

As estratégias das cidades para monitorizar e garantir o cumprimento das suas regras têm sido diversas. Em Londres um acordo com a plataforma 
Figura $1 \downarrow$ Anúncio de garagem/bar para arrendamento turístico, Praga, República Checa

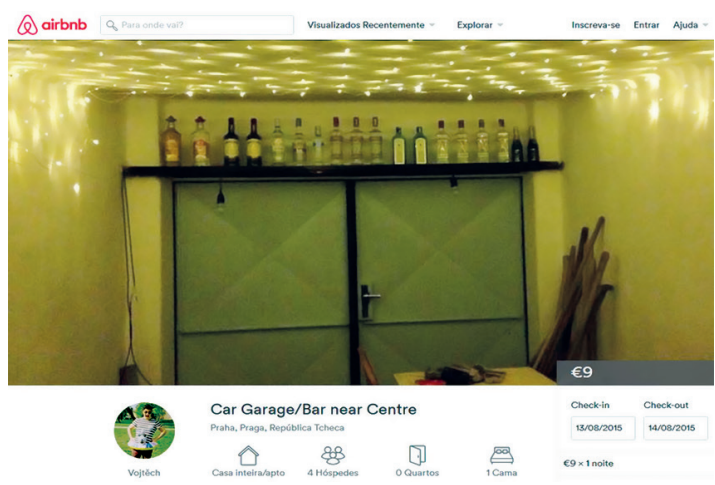

Fonte: Plataforma Airbnb (2015)

Airbnb garante o bloqueio automático para além dos 90 dias, mas surge a dúvida sobre se os proprietários irão cumprir ou simplesmente utilizar outras plataformas. Em 2016, a cidade de Barcelona multou a plataforma em 600 mil euros por continuar a publicitar quartos não licenciados, mas a prática continua. O número de inspetores dedicados a encontrar alojamentos ilegais em Barcelona tem vindo a ser amplamente reforçado, assim como o valor das multas (Segú, 2018). Em Nova Iorque, apesar da lei em vigor, continuam a ser publicitados milhares de anúncios de apartamentos inteiros (Dudás et al., 2017).

Devido à elevada pressão na obtenção de dados, surgem, por um lado, empresas dedicadas à extração de dados das plataformas, como a não-comercial Inside Airbnb ${ }^{5}$ e a comercial Airdna ${ }^{6}$. Esta última disponibiliza informação estatística e georreferenciada sobre as propriedades publicitadas na Airbnb nas principais cidades, utilizando sofisticados métodos de inteligência artificial para distinguir as datas de ocupação daquelas bloqueadas pelos anfitriões. Surgem ainda notícias de startups dedicadas a reunir informação sobre as atividades não regulamentares, para venda de informação a vizinhos ou às instituições da administração (Gurran \& Phibbs, 2017). Estas novas startups criam uma ferramenta importante na regulação não formal nesta era de economia de partilha. Atenta também às repercussões na vizinhança, a Airbnb criou em 2016 uma ferramenta online ${ }^{7}$ onde os vizinhos podem reclamar sobre o comportamento dos visitantes, prometendo que as queixas irão ser encaminhadas aos anfitriões.

Dada a juventude das medidas, ainda será cedo para avaliar o grau de eficácia das restrições e, mais importante, se as estratégias adotadas conseguirão minimizar a prevenção das principais externalidades negativas sentidas, nomeadamente a escalada do preço da habitação.
Figura $2 \triangleright$ Anúncio de carrinha vintage para arrendamento turístico, NI, EUA

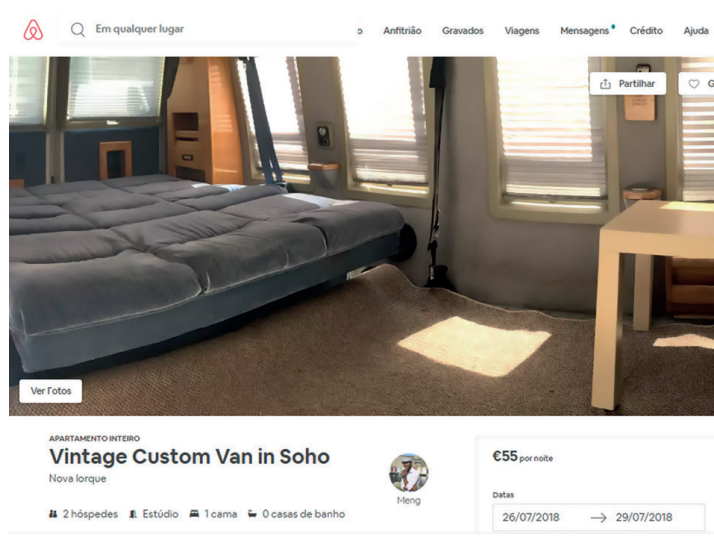

Fonte: Plataforma Airbnb (2018)

\section{Estratégias e regulação em Portugal}

Em Portugal, as propostas dos grupos parlamentares sucedem-se e a discussão do tema está também na ordem do dia. Contudo, quais são as perspetivas de a administração portuguesa conseguir efetivamente implementar normas restritivas ao alojamento local? Estará a administração portuguesa preparada para monitorizar, fiscalizar e lidar com os desvios às regras? Conseguirá obter sucesso onde outras cidades falharam até ao momento?

Com vista a um prognóstico, importa, por um lado, perceber o que foi feito até ao momento e, por outro, dar algumas notas sobre o comportamento da administração portuguesa na matéria mais genérica de ilegalidade urbanística.

Em Portugal, o alojamento local foi uma atividade sem enquadramento legal específico até 2008. A figura do alojamento local foi criada nesse ano ${ }^{8}$ para regular a prestação de serviços de alojamento temporário em estabelecimentos sem os requisitos legalmente exigidos para se qualificarem como empreendimentos turísticos. Em $2014^{9}$ a atividade passou a ser regulada por um documento legal específico e veio introduzir a obrigação de registo. O processo de registo pressupõe a apresentação de declaração de início de atividade no serviço de Finanças, com o respetivo Código de Atividade Económica (CAE) e a indicação do título de utilização da habitação (emitido pela Câmara Municipal no âmbito do licenciamento de obras particulares). Estas medidas visam, por um lado, mecanismos para garantir uma menor evasão fiscal e, por outro, assegurar as condições de habitabilidade dos alojamentos disponibilizados a turistas.

Em $2015^{10}$ o regime do alojamento local foi reforçado no sentido de tornar obrigatória a menção ao número de registo no anúncio e de estipular a correspondente contraordenação. A nível municipal, a 
preocupação é também de índole económica. Desde janeiro de 2016, o município de Lisboa aplica uma taxa turística, tendo sido seguido pelo município do Porto em março de 2018. À semelhança de outras cidades europeias, um acordo entre a Airbnb e os municípios de Lisboa e Porto garante a cobrança direta da taxa turística aplicável, ficando os proprietários responsáveis pela liquidação nos restantes casos. Assim, podemos dizer que as medidas aplicadas até ao momento têm subjacentes preocupações pecuniárias, não prefigurando qualquer restrição de índole urbanística, já que as taxas e impostos são aplicados de igual forma sem distinção de localização, densidade ou tipo de alojamento.

No sentido de combater a ausência de habitação a preços acessíveis a estudantes deslocados, o governo criou medidas positivas de incentivo ao aumento da oferta de habitação através do Plano Nacional de Alojamento para o Ensino Superior PNAES (República Portuguesa, 2018). O PNAES assenta prioritariamente na reabilitação de edificado existente, valorizando o património local e a coesão social. A questão do alojamento de estudantes exige uma estratégia integrada e a longo prazo (República Portuguesa, 2018). Esta é uma iniciativa que representa uma solução paliativa no caso específico dos estudantes, porém, será insuficiente para resolver a proliferação e o impacto do alojamento local nas principais cidades.

Com uma reduzida tradição de monitorização e fiscalização, o panorama português de efetiva implementação da (mínima) regulação da atividade não dá sinais positivos. Uma simples pesquisa na Airbnb revela a existência de vários anúncios sem referência ao registo ou, um pouco mais preocupante, em locais onde este não pode ser obtido, como por exemplo em áreas do domínio público (Calor \& Magarotto, 2018). Consubstanciando esta tese, um estudo da Nova School of Business and Economics e da Faculdade de Direito da Universidade Nova de Lisboa (AHRESP, 2016) denota que o número de alojamentos registados no Registo Nacional de Alojamento Local em setembro de 2016 é muito inferior aos anúncios publicitados na Airbnb em vários municípios portugueses. Na capital, a diferença é de quase 3500 propriedades, correspondendo a 37,4\% das propriedades publicitadas na Airbnb. As freguesias de Santa Maria Maior e da Misericórdia (em Lisboa) e o Centro na Cidade do Porto apresentam a maior disparidade nos números - alcançando mais de $50 \%$ nas freguesias centrais no Porto. Curiosamente, uma notícia recente vem dar nota da superação em $50 \%$ das expectativas do município do Porto em relação à cobrança da taxa turística (Lusa, 2018). Sendo a taxa cobrada diretamente pela plataforma Airbnb, estará esta diferença relacionada com a diferença do número de alojamentos registados e aqueles efetivamente disponibilizados para arrendamento?
Estes resultados indiciam que uma elevada percentagem das propriedades operava sem registo em 2016 e provavelmente ainda se encontram nessa situação. Será interessante aferir em anos subsequentes se os números espelham o aumento ou diminuição desta disparidade entre alojamentos publicitados e registados. Nesta matéria não podemos deixar de refletir sobre a (sempre atual) pertinência da equação de Bowles que estima "20 por centro da população regulada irão automaticamente cumprir com qualquer regulamentação, cinco por cento tentarão não cumpri-la, e os restantes 75 por cento irão cumprir desde que pensem que os cinco por cento vão ser apanhados e punidos" (Bowles, 1971 in Zaelke et al., 2005, p. 24).

\section{Governança municipal e estratégia urbanística}

O intenso debate político sobre as restrições ao alojamento local culminou com a recente aprovação de uma segunda alteração ao regime do alojamento local ${ }^{11} \mathrm{com}$ entrada em vigor no próximo dia 21 de outubro. As alterações introduzidas visam (entre as relacionadas com a salvaguarda das relações de vizinhança e condomínios) conferir aos municípios poderes para estabelecer zonamento, restrições ao número de alojamentos locais e cancelamento de registos. Esta lei habilita assim os municípios a traçarem a (tão necessária) estratégia de índole urbanística, enquanto ferramenta essencial para repor o equilíbrio com a função habitacional de longa duração e a preços acessíveis nas principais cidades do país.

Aguarda-se com expectativa saber como esta estratégia será delineada, mas, mais do que isso, se os municípios portugueses serão capazes de garantir a sua execução. Como demonstram os dados quantitativos acima mencionados, regulamentar não basta. A monitorização em continuum da atividade é uma peça essencial, sobretudo atendendo ao dinamismo do setor.

A nível da capacidade de monitorização e fiscalização dos municípios, as reticências são elevadas. Isto porque em matéria de fiscalização urbanística os municípios tendem a ser brandos e condescendentes. A afirmação de que "a fiscalização é o elo mais fraco do sistema de planeamento urbanístico" (Dobry, 1975 in McKay \& Ellis, 2005) mantém-se atual e pertinente. Em Portugal, por considerações políticas e económicas, as medidas de tutela da legalidade urbanística raramente são levadas até ao fim (Leite, 2010; Lopes, 2004). Um estudo baseado em entrevistas a vários municípios da região do Oeste e Vale do Tejo constatou que a postura municipal em relação às infrações urbanísticas em geral é deveras facilitadora e as suas ações minimizadas, para evitar "incómodos" aos 
particulares e à autarquia (Calor, 2017). A reduzida fiscalização é associada à facilitação da legalização de operações urbanísticas já consolidadas, para o que concorrem os argumentos de resolver o "problema" ao cidadão-eleitor e, por outro lado, de arrecadar as taxas urbanísticas associadas.

Por conta da pressão imobiliária é previsível que nas principais cidades portuguesas aumente a divisão de apartamentos com vista ao aumento do número de fogos. Este fenómeno é constatado em muitas cidades onde o preço da habitação é elevado. A subdivisão de casas ou frações em Inglaterra e a criação de novas unidades habitacionais em caves de habitações de Calgary são exemplos documentados na literatura (Cauvain \& Bouzarovski, 2016; Tanasescu, Wing-tak, \& Smart, 2010). Este tipo de transformação urbana é especialmente desafiador, por ter pouca expressão física externa e ser mais difícil de fiscalizar (do que, por exemplo, uma nova construção ou uma ampliação).

Como tal, a mudança de paradigma na fiscalização municipal é necessária para fazer face a estas mudanças e ao impulso do alojamento local. Uma regulamentação bem desenhada (com regras que sejam fiscalizáveis) e a especialização das equipas de fiscalização parecem uma inevitabilidade, bem como a agilização da estrutura municipal para uma resposta atempada. Estarão os municípios portugueses preparados para o desafio?

\section{Conclusão}

O rápido crescimento do alojamento local causou nas cidades portuguesas uma mudança de paradigma a nível urbanístico. O aumento do preço da habitação, a conflitualidade entre condóminos, a "turistificação" e o agravamento da terciarização dos centros das cidades são alguns dos problemas apontados. O crescimento do setor tem sido acompanhado pelas tentativas para regular a atividade. As medidas adotadas até ao momento têm enfoque nas questões pecuniárias e na receita para a administração, mas as alterações introduzidas recentemente abriram (por fim) a possibilidade de os municípios traçarem uma estratégia urbanística. Neste âmbito, do ponto de vista conceptual, o alojamento local é um interessante exemplo de como os conceitos de legalidade e ilegalidade são moldados pelas entidades reguladoras e mutáveis no decurso do tempo. Será importante fazer notar que o alojamento temporário para turistas não é uma atividade nova no nosso país, tendo precedentes sobejamente conhecidos no Algarve e nas zonas balneares. No entanto, até ao fenómeno de globalização proporcionado pelas plataformas online, esta foi uma atividade livre de restrições e merecedora de pouca atenção social.

Mas o desafio atual prende-se mais com a implementação do que com a regulação. O estudo da Nova School of Business and Economics de 2016 (AHRESP, 2016) demonstra que o alcance da regulamentação aplicável teve efeitos limitados. A diferença de $50 \%$ entre os alojamentos registados e aqueles publicitados na plataforma Airbnb no centro do Porto demonstra que não é suficiente produzir regulamentação, e a monitorização é um elemento-chave do processo.

Para as entidades públicas, a monitorização e fiscalização significa um esforço económico e de recursos humanos acrescidos. No caso dos municípios de Lisboa e Porto, e tendo em conta o acordo com a Airbnb constata-se que todos os alojamentos revertem para a taxa turística, mesmo quando não possuem registo. Ou seja, para alcançar maior receita, o interesse do município é ter o maior número possível de alojamentos, independentemente da sua condição de "legalidade". Com este paradigma repete-se um "velho" constrangimento dos particulares perante a administração quanto às construções ilegais: o facto de um segmento da administração (Serviço de Finanças) exigir a contribuição autárquica do imóvel e outro segmento (autarquias) alegar o desconhecimento da sua condição de ilegalidade. Esta aparente contradição repete-se no caso da taxa turística.

Nesta perspetiva, a verificação do cumprimento das obrigações legais de registo ou fiscais não deve ser encarada apenas como uma questão formal nem apenas como responsabilidade da administração, sendo antes uma questão de ordem, justiça e responsabilidade social. Por outro lado, para os consumidores existe também uma responsabilidade "social" que passa por proceder à verificação da legalidade do alojamento a arrendar, enquanto atitude consciente e de respeito pelos habitantes do local de destino.

\section{Notas}

1 https://press.airbnb.com/pt/fact-facts/ (acedido em 06/10/2018).

2 Artigo 2. ${ }^{\circ}$ do Decreto-Lei n. ${ }^{\circ}$ 128/2014, de 29 de agosto.

3 https://www.airbnb.pt/rooms/10457093 (acedido em 26/6/2015).

4 https://www.airbnb.pt/rooms/25374851 (acedido em 6/10/2018).

5 http://insideairbnb.com/ (acedido a 01/10/2018).

6 https://www.airdna.co/ (acedido a 01/10/2018).

7 https://www.airbnb.com.au/neighbors (acedido a 01/10/2018).

8 Decreto-Lei n. ${ }^{0}$ 39/2008, de 7 de março.

9 O Decreto-Lei n. ${ }^{\circ}$ 128/2014, de 29 de agosto, aprovou o regime jurídico da exploração dos estabelecimentos de alojamento local.

10 O Decreto-Lei 63/2015, de 23 de abril de agosto, altera o regime de autorização de exploração dos estabelecimentos 
de alojamento local, procedendo à primeira alteração ao Decreto-Lei n.o 128/2014, de 29 de agosto.

11 Lei n. ${ }^{\circ}$ 62/2018, de 22 de agosto, que altera o regime de autorização de exploração dos estabelecimentos de alojamento local, procedendo à segunda alteração ao Decreto-Lei n.o 128/2014, de 29 de agosto.

\section{Referências bibliográficas}

AHRESP. (2016). O Alojamento Local em Portugal qual o fenómeno? (1.a ed.; AHP, Ed.). Lisboa, Portugal: AHP.

Bowles, C. (1971). Promises to Keep: My Years in Public Service, 1941-1969. HarperCollins.

Calor, I. (2017). A ilegalidade urbanística e o sistema de planeamento territorial. Perspetiva comparada sobre políticas e práticas de controlo urbanístico de obras particulares (tese de doutoramento). Lisboa: Faculdade de Ciências Sociais e Humanas. Universidade Nova de Lisboa.

Calor, I., \& Alterman, R. (2017). When enforcement fails. Comparative analysis of the legal and planning responses to non-compliant development in two advanced-economy countries. International. Journal of Law in the Built Environment, 9(3), 207-239. doi: 10.1108/IJLBE-06-2017-0021

Calor, I., \& Magarotto, M. G. (2018). Construções ilegais nas ilhas da Ria Formosa (Algarve, Portugal). In A. Miranda, M. Lopes, L. Tarelho, F. Martins, P. Roebeling, M. Coelho \& J. Labrincha (Eds.) CIALP - Conferência Internacional de Ambiente em Língua Portuguesa (pp. 582-592). Aveiro: Departamento de Ambiente e Ordenamento, Universidade de Aveiro.

Cauvain, J., \& Bouzarovski, S. (2016). Energy vulnerability in multiple occupancy housing: a problem that policy forgot. People, Place and Policy, 10(1), 88-106. doi: 10.3351/ppp.0010.0001.0007

Decreto-Lei n.o 128/2014 de 29 de Agosto. Diário da República n.o 166/2014 - Série I. Lisboa: Ministério da Economia

Decreto-Lei n. 0 39/2008 de 7 de Março. Diário da República n.o 48/2008 - Série I. Lisboa: Ministério da Economia e da Inovação

Decreto-Lei n.o 128/2014 de 29 de Agosto. Diário da República n.o 166/2014 - Série I. Lisboa: Ministério da Economia

Decreto-Lei 63/2015 de 23 de Abril. Diário da República n.o 79/2015 - Série I. Lisboa: Ministério da Economia

Dobry. (1975). Investigation into Planning Enforcement, The Dobry Report. London.

Dudás, G., Vida, G., Kovalcsik, T., \& Boros, L. (2017). A socio-economic analysis of Airbnb in New York City. Regional Statistics, 7(1), 135-151. doi:10.15196/ RS07108

Ferreri, M., \& Sanyal, R. (2018). Platform economies and urban planning: Airbnb and regulated deregulation in London. Urban Studies. doi: $10.1177 / 0042098017751982$
Gregory, A., \& Halff, G. (2017). Understanding public relations in the "sharing economy". Public Relations Review, 43(1), 4-13. doi:10.1016/j. pubrev.2016.10.008

Gurran, N. (2017). Global Home-Sharing, Local Communities and the Airbnb Debate: A Planning Research Agenda. Planning Theory and Practice, 9357, 1-7. doi: $10.1080 / 14649357.2017 .1383731$

Gurran, N., \& Phibbs, P. (2017). When Tourists Move In: How Should Urban Planners Respond to Airbnb? Journal of the American Planning Association, 83(1), 80-92. doi: 10.1080/01944363.2016.1249011

INE. (2017). Estatísticas da Construção e Habitação 2017 (1st ed.; I. INE, Ed.). Lisboa, Portugal: INE.

Lei n. ${ }^{\circ}$ 62/2018 de 22 de Agosto. Diário da República n. ${ }^{\circ} 161 / 2018$ - Série I. Lisboa: Assembleia da República

Leite, A. (2010). Demolição vs Legalização. Não demolir, sem transigir -- que solução? In F. P. Oliveira (Ed.), O urbanismo, o ordenamento do território e os tribunais (pp. 461-476). Almedina.

Lopes, D. (2004). Medidas de tutela da legalidade urbanística. Revista CEDOUA, 14, 49-90.

Lopes, R. (2018). O impacte urbanístico e socioeconómico do Alojamento Local na cidade de Lisboa (WP 2018/05) Lisboa: Dinâmia-CET.

Lusa. (2018, Agosto 23). Taxa turística cobrada no Porto 50\% acima das expetativas. Observador. Retirado de https://observador.pt/2018/08/23/ taxa-turistica-cobrada-no-porto-50-acima-dasexpetativas/

Martin, C. J. (2016). The sharing economy: A pathway to sustainability or a nightmarish form of neoliberal capitalism?. Ecological Economics, 121, 149-159. doi: 10.1016/j.ecolecon.2015.11.027

McKay, S., \& Ellis, G. (2005). Reparation or retribution: An investigation into regulatory compliance in planning. Environment and Planning $A, 37(7)$, 1249-1262. doi:10.1068/a36288

Mendes, L. (2014). Gentrificação e políticas de reabilitação urbana em Portugal: uma análise crítica à luz da tese rent gap de Neil Smith. Cadernos Metrópole, 16(32), 51-72. doi:10.1590/22369996.2014-3209

Munkøe, M. M. (2017). Regulating the European Sharing Economy: State of Play and Challenges. Intereconomics, 52(1), 38-44. doi:10.1007/ s10272-017-0641-3

República Portuguesa (2018). Plano nacional para o alojamento local. Lisboa: Portugal.

Segú, M. (2018). Do short-term rent platforms affect rents? Evidence from Airbnb in Barcelona.

Tanasescu, A., Wing-tak, E. C., \& Smart, A. (2010). Tops and bottoms: State tolerance of illegal housing in Hong Kong and Calgary. Habitat International, 34(4), 478-484. doi:10.1016/j. habitatint.2010.02.004

Turismo de Portugal, I. (2007). O Plano Estratégico Nacional do Turismo. Lisboa: Turismo de Portugal. 
Zaelke, D., Kaniaru, D., \& Kružiková, E. (2005). Compliance Theories. In D. Zaelke, D. Kaniaru, \& E. Kružiková (Eds.), Making law work: Environmental compliance \& sustainable development I ( $\mathrm{pp}$. 53-62). Cameron May Ltd., International Law Publishers.

Inês Calor (icalor@gmail.com). Investigadora independente, Porto.

Mateus Magarotto (mateusmagarotto@gmail.com). LEGECE - Departamento de Oceanografia da Universidade Federal de Pernambuco, Avenida da Arquitetura, s/n, Cidade Universitária, 50750-550 Recife, Brasil e CEGOT Departamento de Geografia da Universidade do Porto, Via Panorâmica, s/n, 4150-564 Porto, Portugal. 


\title{
O PAPEL DO CROWDFUNDING NA DINAMIZAÇÃO DO SETOR IMOBILIÁRIO THE ROLE OF CROWDFUNDING IN PROMOTING REAL ESTATE INDUSTRY
}

\author{
Miguel Neves Matias \\ Instituto Politécnico de Leiria
}

\begin{abstract}
Resumo
A regulamentação recente do crowdfunding em Portugal vem chamar a atenção para o contributo efetivo que este instrumento pode representar para o desenvolvimento e sustentabilidade do setor imobiliário. O presente artigo tem como objetivo discutir as virtualidades do crowdfunding no financiamento de projetos imobiliários, num contexto em que o setor imobiliário perdeu dimensão nos últimos anos, com todas as externalidades negativas que daí advieram, a par com um sistema bancário que tem vindo a reduzir a sua exposição a este setor.

São analisadas as várias fontes de financiamento do setor imobiliário, alternativas ao crédito bancário tradicional, sendo focada a atenção no crowdfunding. Partindo da análise apresentada, são apresentadas, em detalhe, as várias modalidades de crowdfunding existentes, o seu modo de funcionamento e as implicações práticas para a industria imobiliária, evidenciando os seus pontos fortes e as suas debilidades.

Conclui-se que o crowdfunding proporciona investimentos mais transparentes, acessíveis, éticos, inclusivos e menos especulativos, mas, dado o seu histórico ainda reduzido, levantam-se várias interrogações acerca do que poderá vir a ser o seu verdadeiro posicionamento e relevância no financiamento imobiliário.
\end{abstract}

Palavras-chave: crowdfunding imobiliário; investimento imobiliário; financiamento pela internet; plataformas de investimento

\section{Abstract}

The recent regulation of crowdfunding in Portugal draws attention to the effective contribution that this instrument can have to the development and sustainability of the real estate business. The purpose of this article is to discuss the potential of crowdfunding in the financing of real estate projects, in a context in which the real estate sector has lost dimension in recent years, with all the negative externalities that have arisen, along with a banking system that has been reducing credit exposure to this sector.

We analyze the various sources of real estate financing that are alternative to traditional bank credit, focusing on crowdfunding. Based on this analysis, we present in detail the various categories of crowdfunding, their mode of operation and the practical implications for the real estate industry, highlighting their strengths and weaknesses.

We conclude that crowdfunding enables investments that are more transparent, accessible, ethical, inclusive and less speculative. But given its small track record, issues arise about what could be the position and relevance of crowdfunding in the real estate financing market.

Keywords: real estate crowdfunding; real estate; internet based finance; investing platforms

\section{Introdução}

A crise financeira global de 2008 obrigou à reanálise, elaboração e implementação de um conjunto de medidas de caráter regulatório que passaram a restringir significativamente a exposição creditícia dos bancos ao setor imobiliário. A partir daí assistiu-se no sistema bancário a uma muito maior diferenciação em termos de requisitos regulatórios de capital, entre crédito de bom e mau risco, desencadeando pela generalidade dos operadores no mercado uma análise de risco mais conservadora e um foco comercial muito direcionado para as melhores empresas e com algum histórico 
no mercado, colocando muitas empresas e projetos empresariais, em particular os direcionados para o setor imobiliário, arredados do canal de crédito bancário.

Com efeito, constatou-se que não só o balanço dos bancos foi significativamente afetado por imóveis que foram perdendo valor ao longo do tempo, como se verificou que grande parte do incumprimento estava concentrado em promotores e investidores imobiliários. A crise ensinou de uma forma dura, mas convincente, que investimentos imobiliários devem ter fontes de financiamento mais diversificadas e menos assentes em dívida.

Tradicionalmente, o financiamento para grandes projetos imobiliários advinha de um conjunto reduzido de bancos com vocação imobiliária. Essas grandes entidades tinham habitualmente limites avultados de capital, disponíveis para empréstimos ou investimentos nesse setor. No entanto, uma forte mudança nas políticas de crédito dos bancos no pós-crise mudou o mindset de todo o mercado de capitais. Esta mudança causou uma lacuna de financiamento para imóveis e empreendimentos urbanos. Os bancos que financiavam grandes projetos pré-crise registaram inclusivamente grandes dificuldades no financiamento de outros setores no pós-crise (Agarwal et al., 2010), reforçando o efeito de contágio, e até sistémico, que o incumprimento verificado no crédito imobiliário provocou.

Face às crescentes exigências de Basileia, os bancos tentam aumentar a sua solvabilidade, limitando os financiamentos aos setores de atividade que consomem mais capital, ou seja, aos mais arriscados, donde se inclui o setor imobiliário.

O desenvolvimento de novos projetos imobiliários é por isso altamente pressionado pelo contexto financeiro da indústria. Os bancos cobram prémios mais elevados, condicionam o montante a financiar o LTV (loan-to-value ratio: rácio entre o valor a financiar e o valor do imóvel afeto como colateral) mais baixos e impõem covenants cada vez mais exigentes, como sejam a contratualização de vendas com prazo definido e arrendamentos antecipados rigorosos (Marchand, 2016). Como resultado, a obtenção de crédito está sujeita a maiores custos de financiamento (pressionando o valor de venda do imóvel) e exigências adicionais. Cada vez menos bancos estão disponíveis para financiar os grandes projetos imobiliários ( $i$. e., a assumir uma concentração de crédito em projetos de grande dimensão), o que obriga investidores e promotores a adiar investimentos e a repensar e diversificar as suas estratégias de financiamento.

Este contexto ilustra a situação difícil dos mercados imobiliários que, perante a inexistência de alternativas, se reflete em propriedades subvalorizadas, na falência de promotores imobiliários, e conduz à emergência de novos instrumentos alternativos de financiamento que forneçam soluções de financiamento exequíveis para empreendimentos imobiliários.

No caso português, analisando especificamente as empresas do CAE 41 (promoção imobiliária e construção de edifícios) ${ }^{1}$, constata-se que o volume de negócios anual agregado nesta atividade, que atingiu um valor de 17,162 mil milhões de euros em 2008 distribuído por 32648 empresas, reduziu-se para cerca de metade em 2017 (8,826 mil milhões de euros) distribuído por 26299 empresas. Em 10 anos o saldo líquido negativo na quantidade de empresas a operar no setor foi de 6349 empresas. 0 Ativo $^{2}$ agregado do setor seguiu a mesma trajetória (tendo passado de 51 mil milhões de euros em 2008 para 28 mil milhões de euros em 2017).

De igual forma, o financiamento bancário afeto a este setor, que representava em média $50 \%$ do ativo das empresas até 2008 , sofreu também uma redução gradual no período, tendo diminuído para $41 \%$ em 2018. Consequentemente, a autonomia financeira (Capital Próprio/Ativo) destas empresas aumentou de $20 \%$ para $26 \%$ nesse período. O setor imobiliário perdeu dimensão, com todas as externalidades negativas que daí advieram, mas ganhou solidez financeira e uma nova forma de encarar e estruturar o investimento e consequente financiamento de novos projetos: menos dependente de dívida e com maior abertura a fontes alternativas de financiamento.

$O$ presente artigo tem como objetivo discutir as virtualidades do crowdfunding no financiamento de projetos imobiliários, num contexto de emagrecimento do setor imobiliário e em que o sistema bancário, como principal e tradicional financiador, tem vindo a reduzir a sua exposição a este setor.

\section{Alternativas ao financiamento bancário}

Para lá do financiamento bancário, podemos identificar 5 fontes de financiamento de projetos imobiliários em crescente dinamismo (Baldwin, 2017):

\section{Forward funding}

De acordo com Wilkinson e Reed (2008), esta modalidade de financiamento envolve um investidor que concede um financiamento para o desenvolvimento a curto prazo de um projeto imobiliário, tendo em vista a sua aquisição futura.

Um investidor estará disponível a assumir o risco do desenvolvimento inicial de um projeto, se perspetivar um potencial de valorização que o acomode. $\mathrm{Na}$ ausência de um contrato de pré-arrendamento significativo, o financiamento a prazo pode reduzir a exposição do financiador ao risco de locação (entre outras formas de risco) associado ao potencial de valorização do arrendamento num mercado em alta. Embora o financiamento a prazo possa reduzir algumas componentes do risco do promotor, a sua 
antecipação pode permitir ao investidor beneficiar de alguma proteção do ativo, por via, por exemplo, de benefícios fiscais, em comparação com o financiamento numa fase mais avançada do ciclo de desenvolvimento do projeto.

Além disso, os investidores que pretendem tornar-se proprietários-ocupantes podem-se envolver no processo de desenvolvimento por meio do modelo "build to suit", no qual o promotor constrói as especificações pretendidas pelo futuro ocupante. Os proprietários industriais são habitualmente os clientes deste tipo de financiamento, além de alguns proprietários de nicho, como sejam os data centers e o setor da assistência médica (onde é menos provável que os requisitos de construção exigidos por estes proprietários sejam fornecidos por promotores [especuladores] num mercado aberto).

Rendas de superfície

Trata-se dos pagamentos periódicos do arrendatário ou utilizador de uma parcela de terreno ao seu proprietário, no âmbito de um contrato de longo prazo. Apesar de o arrendamento de superfície não ser um tema recente, nos últimos anos, o tratamento dado pelos investidores aos investimentos de renda fixa tornou-se cada vez mais inovador (Flood, 2013). Porque os investimentos imobiliários são vistos por muitos investidores como um investimento relativamente seguro, nos últimos anos vários fundos de investimento mais inovadores têm-se tornado mais ativos neste setor, adquirindo carteiras significativas (muitas vezes diretamente ao promotor, durante os estágios iniciais de um investimento) e impulsionando os retornos, através da sua alavancagem.

\section{Securitização}

A securitização é uma prática financeira que consiste no agrupamento e classificação de vários tipos de ativos financeiros em função do seu risco e valor económico (nomeadamente, títulos de crédito, tais como faturas emitidas e ainda não pagas [v. g., recebíveis], dívidas referentes a empréstimos, leasings, entre outros), convertendo-os em títulos padronizados negociáveis no mercado de capitais. A dívida é transferida para uma sociedade instrumental (special purpose vehicle - SPV) e vendida, na forma de títulos, a vários investidores. A securitização de ativos imobiliários tem assistido a vários desenvolvimentos nos últimos anos, incluindo fundos de propriedade única, empresas de propriedade de ativos únicos e fundos de investimento imobiliário.

Wilkinson e Reed (2008) observam a crescente atividade em técnicas de financiamento de capital nos últimos anos nos mercados financeiros, na tentativa de reduzir muitos dos problemas inerentes ao modelo de financiamento imobiliário, como sejam a falta de liquidez, falta de comparabilidade com outras classes de ativos, falta de um mercado único, falta de transparência e o grande volume de capital exigido por muitos empreendimentos imobiliários. A proliferação deste instrumento pode aumentar a oferta de capital disponível para o promotor durante o processo de desenvolvimento.

\section{Mercado secundário}

De acordo com Baldwin (2017), com o eclodir da crise financeira global de 2008, nos EUA, a percentagem dos empréstimos imobiliários com incumprimento nos bancos aumentou cerca de $94 \%$ entre o quarto trimestre de 2005 e o segundo trimestre de 2010, caindo drasticamente a partir daí. Uma das consequências foi o aumento significativo do mercado secundário de empréstimos imobiliários, à medida que os bancos tentavam transferir a sua dívida subvalorizada para novos investidores. Os investidores conseguiram assim adquirir carteiras de empréstimos com incumprimento junto dos credores, com o objetivo de, entre outras estratégias de valorização, reestruturar os financiamentos associados aos investimentos imobiliários, assumir o controlo do(s) ativo(s) e/ou continuar o processo de desenvolvimento dos projetos ${ }^{3}$.

É provável que este mercado secundário mantenha algum dinamismo a médio prazo, de acordo com Baldwin (2017), particularmente no sul da Europa, uma vez que vários bancos europeus, passada a crise financeira, mantêm ainda um volume crescente de empréstimos em incumprimento nos seus balanços. Da mesma forma, o mercado secundário de participação privada acionista em projetos imobiliários (conhecido como "real estate private placement market") tornou-se também mais frequente nos últimos anos, em que fundos especializados têm vindo a adquirir participações em investimentos imobiliários ainda em desenvolvimento, diretamente a investidores que participaram na fase inicial e pretendem realizar capital antes da conclusão do projeto imobiliário.

\section{Crowdfunding}

O crowdfunding democratiza e avança um passo no processo de securitização (Baldwin, 2017), através de um processo que tem sido descrito como "um esforço coletivo de consumidores que fazem o networking e juntam dinheiro, geralmente pela internet, para investir e apoiar os esforços iniciados por outras pessoas ou organizações" (Ordanini, Miceli, Pizzeti \& Parasuraman, 2011, p. 443). Através de uma plataforma que intermedeia o processo de captação de capital, um empreendedor obtém capital externo junto da "multidão" (ou seja, o público em geral), em alternativa à captação de capital junto de um único investidor institucional ou de um pequeno 
sindicato de investidores (Belleflamme, Lambert \& Schwienbacher, 2014).

O crowdfunding começou inicialmente por ganhar popularidade e importância no financiamento de projetos sociais, startups e todo o tipo de negócios inovadores (Howe, 2006), cujo acesso às fontes tradicionais de financiamento se afigurava difícil ou mesmo impossível (Jenik, Lyman \& Nava, 2017), dada a ausência de histórico e/ou colaterais e dificuldades diversas em assegurar um cash-flow considerado aceitável para esses financiadores tradicionais (Schwienbacher \& Larralde, 2010).

Em Portugal, o crowdfunding deu os seus primeiros passos em 2011 através do surgimento de duas plataformas vocacionadas para a angariação de financiamento para projetos sociais ou pequenos projetos pessoais de cariz empresarial: a ppl. pt e a massivemov.pt. O seu enquadramento legal despertou as primeiras atenções em 2013, através da criação do Projeto de Lei n.0 419/XII, do Partido Socialista. Em agosto de 2015 foi aprovada a Lei n. ${ }^{\circ}$ 102/2015, que veio regular a atividade de "financiamento de entidades, ou das suas atividades e projetos, através do seu registo em plataformas eletrónicas acessíveis através da internet, a partir das quais procedem à angariação de parcelas de investimento provenientes de um ou vários investidores individuais" (art. 2. $\left.{ }^{\circ}\right)^{4}$.

No que se refere ao investimento imobiliário, o crowdfunding está entre os mais recentes instrumentos de financiamento chegados ao mercado, tendo começado a mostrar os primeiros resultados, e consequentemente a despertar atenção, a partir de meados de 2014. Em julho desse ano foi concluída aquela que é considerada a primeira grande operação de crowdfunding imobiliário, quase sem publicidade, quando um grupo de 85 investidores particulares ficou com $15 \%$ da propriedade do Hotel Hard Rock de Palm Springs na Califórnia por 1,5 milhões de dólares ${ }^{5}$.

Contudo, a operação mais relevante, até à data, foi concretizada um ano depois. Wang Jianlin, um dos homens mais ricos do mundo, conseguiu angariar, através do seu conglomerado empresarial Dalian Wanda, em junho de 2015 e em apenas três dias, 5 mil milhões de yuans ( 805 milhões de dólares, aproximadamente), destinados à construção de um mega complexo imobiliário composto por cinco centros comerciais, através de crowdfunding, evitando as incómodas e morosas reuniões com investidores ${ }^{6}$. Nessa campanha de captação de fundos através da internet, era proposta aos investidores uma taxa de retorno anual de $12 \%$ (via rendas recebidas), mediante um investimento mínimo de 160 dólares e uma recuperação do investimento após 5 ou 6 anos, através da venda dos imóveis.

Desde então, e principalmente após a operação do grupo Wanda, o crowdfunding imobiliário, conhecido por real estate crowdfunding (doravante designado RE crowdfunding), parece evidenciar que pode ter um papel importante na dinamização do setor imobiliário, por via da maior capacidade de dispersar e diluir o risco do imobiliário por múltiplos investidores, na redução da volatilidade do seu preço e consequentemente na minimização de crises económicas sistémicas.

Em Portugal, o RE crowdfunding ainda está numa fase inicial, encontrando-se a funcionar a housers. com, uma plataforma de origem espanhola, constituída em 2016 (que entrou no mercado nacional em agosto de 2017) e as portuguesas portugalcrowd.pt e izilend.com.

\section{Modo de funcionamento do crowdfunding}

O financiamento colaborativo (ou crowdfunding) é (mais) um instrumento de captação de recursos que o poder da internet, no âmbito da economia da partilha, colocou ao serviço do empreendedor (Bailey \& Bakos, 1997), e que se materializa no facto de um conjunto de pessoas apoiar financeiramente e de forma direta um projeto, mediado por uma plataforma especializada, que se encarrega de o difundir e apresentar à comunidade, recolher desta o capital solicitado e entregá-lo ao empreendedor.

Podemos então identificar três figuras no crowdfunding: o beneficiário que desenvolve o projeto a ser financiado; a multiplicidade de investidores "anónimos" que financiam o projeto; e a plataforma de negociação que funciona como intermediário entre o beneficiário e os investidores. Uma particularidade importante nas operações de crowdfunding é a de que a operação só é considerada fechada (i. e., o montante angariado só será entregue ao beneficiário) se a totalidade do montante pretendido for angariado no prazo definido. Só nesse caso os investidores interessados no investimento são chamados a contribuir ou a colocar os montantes numa conta de depósito escrow ${ }^{7}$.

Não se atingindo o valor global definido, estes não são chamados com as entradas (o sistema funciona sob uma espécie de procura prévia de intenções) ou, se tiver havido alguma contribuição, procede-se à sua restituição.

$\mathrm{O}$ crowdfunding pode assumir quatro modalidades: donation, reward, debt e equity, que apresentam diferentes formas de contribuição, retorno e motivações de investimento, conforme descrito no Quadro 1.

O RE crowdfunding assume as modalidades de debt crowdfunding ou equity crowdfunding, pois ora o investidor financia uma parte de um determinado projeto imobiliário, recebendo juros e o capital emprestado no final de um determinado período previamente acordado entre as partes, ora se torna dono de uma participação do projeto, recebendo 
Figura $1 \triangleright$ Modo de funcionamento de uma plataforma de crowdfunding

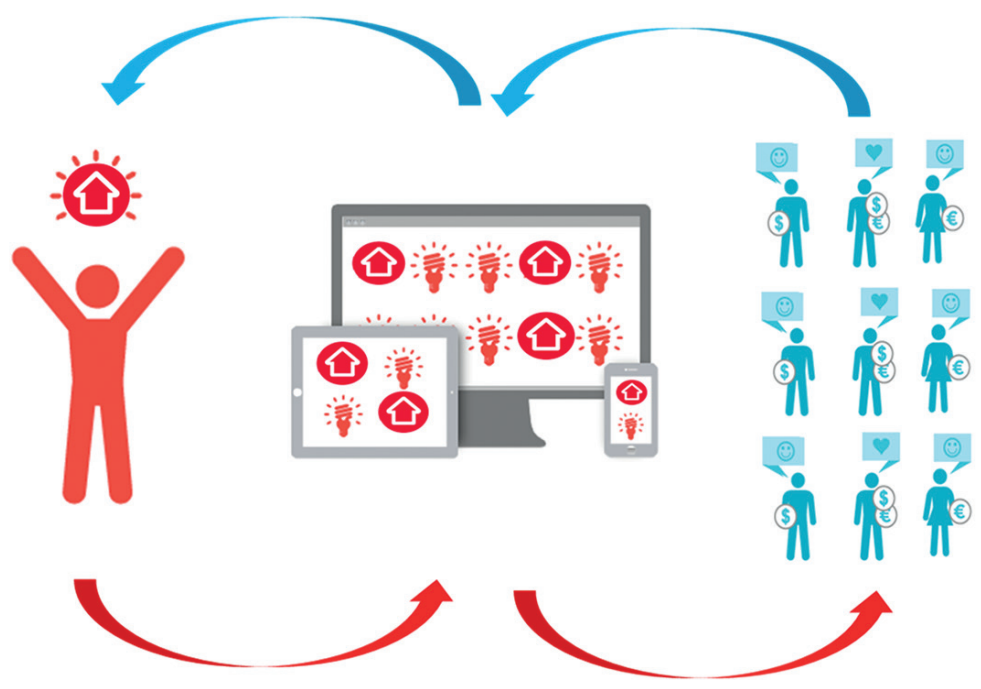

Fonte: Crowdfunding system in https://www.mipise.com (acedido em 19-10-2017) (adaptado) tal diretamente junto do grande público. Os investimentos podem compreender valores mobiliários da empresa promotora, não se referindo a nenhum projeto em particular, mas são mais comummente estruturados como títulos de um projeto imobiliário específico, através de uma sociedade instrumental criada para o efeito (SPV).

As plataformas lideradas por investidores captam o capital e realizam o trabalho de due diligence para avaliar a credibilidade e adequação dos promotores e dos projetos, antes de os listar nas plataformas e, uma vez aceites, fornecem aos potenciais investidores uma análise detalhada do projeto e do investimento, para suporte à tomada de decisão.

Quadro $1 \triangleright$ Modalidades de crowdfunding

\begin{tabular}{l|l|l|l}
\hline \multicolumn{1}{c|}{ Modalidades } & Contribuição & \multicolumn{1}{c}{ Retorno } & \multicolumn{1}{c}{ Motivaçães do investidor } \\
\hline $\begin{array}{l}\text { Donation } \\
\text { crowdfunding }\end{array}$ & Donativo & Benefícios intangíveis & Apoio de causas com as quais se identifica \\
\hline $\begin{array}{l}\text { Reward } \\
\text { crowdfunding }\end{array}$ & Donativo & $\begin{array}{l}\text { Recompensa não financeira: brinde } \\
\text { ou exemplar de produto ou serviço } \\
\text { apoiado }\end{array}$ & $\begin{array}{l}\text { Combinação da motivação intrínseca e so- } \\
\text { cial com o desejo da recompensa, sendo } \\
\text { uma ótima forma de testar produtos no } \\
\text { mercado e avaliar o interesse do público na } \\
\text { sua aquisição }\end{array}$ \\
\hline $\begin{array}{l}\text { Debt } \\
\text { crowdfunding }\end{array}$ & Empréstimo & $\begin{array}{l}\text { Reembolso futuro do empréstimo } \\
\text { com ou sem juros }\end{array}$ & $\begin{array}{l}\text { Obtenção de retornos superiores aos obti- } \\
\text { dos no mercado }\end{array}$ \\
\hline $\begin{array}{l}\text { Equity } \\
\text { crowdfunding }\end{array}$ & Investimento & $\begin{array}{l}\text { Participação societária e/ou o direi- } \\
\text { to de receber parte dos lucros }\end{array}$ & $\begin{array}{l}\text { Participação direta num projeto empresa- } \\
\text { rial, podendo ainda aliar à participação fi- } \\
\text { nanceira a intervenção na sua gestão }\end{array}$ \\
\hline
\end{tabular}

os rendimentos gerados, como sejam as rendas e outros rendimentos gerados pelo investimento, respetivamente.

A plataforma deve apresentar uma proposta de valor de forma estruturada que inclua a tipologia de investimento (hotel, retalho, multifamiliar), estrutura do investimento (capital [equity] ou dívida $[d e b t]$ ), proposta de investimento (valorização do investimento; taxa de juro); duração e estratégias de saída, entre outros detalhes.

Em termos do modelo de negócio de RE crowdfunding, as plataformas enquadram-se em plataformas de promotor e de investidores (O'Roarty, 2016).

Por plataformas do promotor entendam-se as plataformas lideradas e dinamizadas por instituições ou grandes empresas imobiliárias com uma marca reputada, capazes de, autonomamente, obter capi-
Os investimentos podem ser feitos direta ou indiretamente pela plataforma, sendo que considerações regulatórias poderão justificar a opção por determinado modelo de investimento, de acordo com O'Roarty (2016).

Nos modelos diretos, a plataforma atua como um mero intermediário financeiro ( $v . g_{.}$, corretor) e estabelece um relacionamento direto entre cada investidor individual e o promotor do projeto. Embora isso tenha vantagens para o promotor, ao estabelecer um relacionamento direto com um grupo de investidores que pode ser aproveitado para outros projetos, aumenta a complexidade da gestão do processo, pois o promotor deve reportar a cada investidor individualmente e garantir que os detalhes ou especificidades de cada contrato ou interação sejam satisfeitos. 
Para o investidor, tem a vantagem de reduzir os custos fixos no acesso ao investimento (poupa um prémio de intermediação). No entanto, atuar como um corretor tende a diminuir a responsabilidade da plataforma e, por sua vez, a profundidade da análise de due diligence requerida. O ónus recai sobre o investidor, que fica responsável por uma due diligence mais detalhada, enquanto a subsequente monitorização e gestão do investimento, para garantir que o promotor entrega o retorno acordado, é repassada para o investidor individual, que pode não ter o conjunto de competências necessárias para o fazer com a eficácia e eficiência desejáveis.

Esta abordagem é mais comum na China, onde as plataformas não podem controlar o dinheiro afeto pelos seus clientes, leia-se investidores, aos projetos, funcionando apenas como geradoras de leads. Noutros mercados, os promotores imobiliários podem usar plataformas de crowdfunding para mobilizar capital, com o investimento a ser transacionado através da plataforma, mas a ser gerido diretamente pelo promotor. Essa forma de investimento direto é um modelo comum para grandes plataformas lideradas por empresas de grande dimensão, bem capitalizadas e com uma marca reputada e experiência comprovada no mercado imobiliário. Em vez de criarem a sua própria plataforma de crowdfunding, preferem associar-se a uma plataforma de crowdfunding já existente, por forma a aproveitar as suas capacidades tecnológicas ${ }^{10}$, de acordo com Manaktala (2015).

Os modelos indiretos transferem a função de plataforma de crowdfunding do corretor para o gestor dos ativos. Os compromissos individuais do investidor são mantidos numa conta de garantia até que o valor global do capital requerido para o projeto seja atingido. Uma vez alcançado, os fundos podem ser investidos, indiretamente, através de uma SPV, no caso de investimento em capital, ou diretamente na empresa financiada, no caso de investimento em dívida.

\section{RE Equity crowdfunding}

A plataforma procura promotores e projetos imobiliários com necessidades de capital, que considera adequados para serem promovidos (due diligence) junto do público investidor, que pretende adquirir uma participação societária no projeto. Não é apenas o investidor individual que é convidado a tornar-se investidor, vários modelos alternativos permitem que pequenos investidores invistam conjuntamente com capitalistas de risco e business angels ${ }^{11}$.

Os investimentos em capital exigem, para efeitos de maior proteção dos investidores, a existência de uma empresa que fica responsável pela gestão do investimento imobiliário (nominee) ${ }^{12} \mathrm{e}$ que intermedeia a relação entre a plataforma de crowdfunding e uma terceira entidade: uma SPV, detentora do projeto imobiliário. A SPV é uma empresa instrumental, independente da empresa promotora, cujo primeiro membro do balanço inclui a participação societária no investimento imobiliário; e o segundo membro, a dispersão do capital necessário à sua concretização pelos investidores. Esta empresa, ao obrigar à separação jurídica (do risco de insolvência) do promotor (e também da plataforma), tem como objetivo, entre outros, isolar os cash-flows do investimento e sobretudo evitar que esses ativos, em caso de insolvência do promotor, integrem a sua massa falida.

Figura $2 \triangleright$ Estrutura básica das operações de RE Equity Crowdfunding

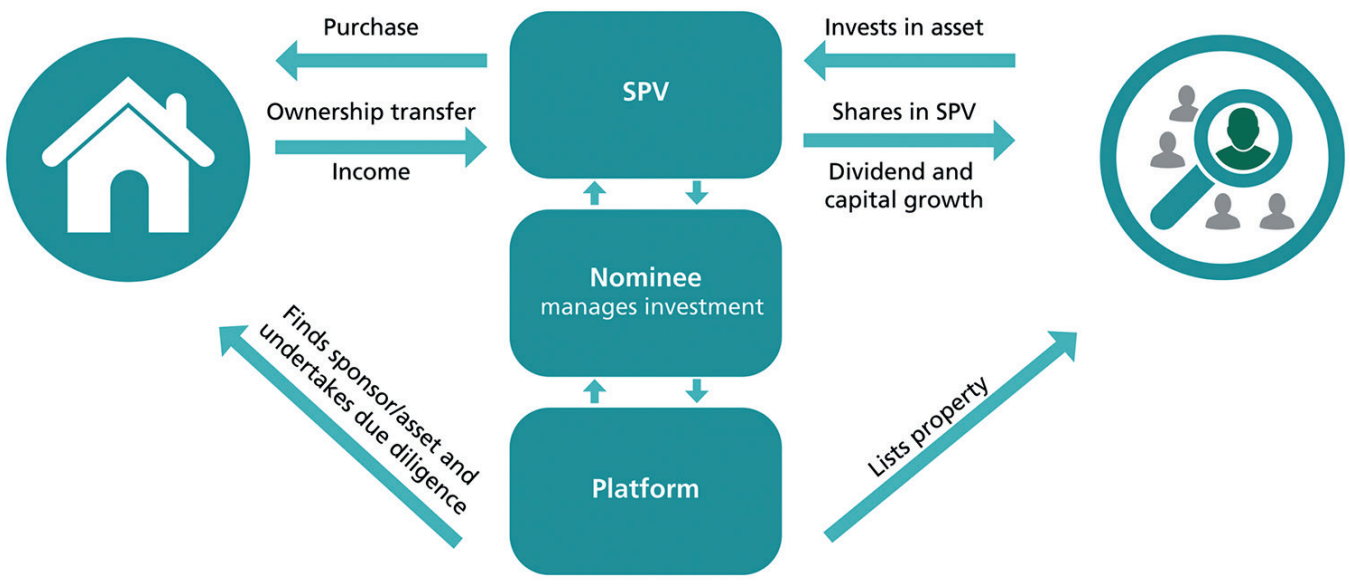

Fonte: O'Roarty (2016), p. 23 
A plataforma fica responsável pela monitorização do desempenho e do cumprimento dos requisitos legais envolvidos na montagem da operação de dispersão de capital e, após a venda do imóvel alvo de investimento, da regular liquidação da SPV.

Nesta modalidade, o investidor garante uma participação no capital da empresa que detém o imóvel e, como tal, o direito a auferir dividendos (por via das rendas imobiliárias) e outros potenciais ganhos de capital (mais-valias por via da venda do imóvel) ${ }^{13}$.

\section{RE Debt crowdfunding}

Na modalidade de debt crowdfunding, a plataforma, tal como no modelo anterior, analisa e seleciona os projetos imobiliários que necessitam de crédito, subscreve o montante necessário e promove a operação de financiamento junto do público, que pode ser colateralizada pelo imóvel alvo de financiamento ${ }^{14}$. Subcontrata também, à semelhança do que foi referido no RE Equity crowdfunding, uma empresa que fica responsável pela gestão do investimento (nominee), que, por sua vez, recorre a uma instituição financeira que irá gerir o empréstimo (criação da conta do investidor/financiador individual destinada a pagamentos e depósitos de valores - investor account) e que terá a vantagem de evitar dificuldades aos credores, perante a eventual insolvência da plataforma (Catarino, 2017).

O investidor seleciona os seus parâmetros preferenciais de risco, maturidade, entre outros, por exemplo, empréstimos de taxa fixa ou variável, e a plataforma autoaloca uma carteira diversificada de empréstimos ao investidor, alinhada com as suas preferências. O investidor atua como mutuante, pelo que a entidade financiada (mutuário) terá de pagar os juros e reembolsar o capital nas condições previstas contratualmente.

Um dos inconvenientes geralmente apontado ao RE Debt crowdfunding, segundo O'Roarty (2016), centra-se no intervalo de tempo que medeia entre a apresentação do projeto e a concretização do financiamento pretendido, o que reduz a capacidade da plataforma de captar e concretizar novos promotores e investimentos e, consequentemente, a sua viabilidade. Como resultado, muitas plataformas procuram pré-financiar os negócios e depois dispersar a operação de financiamento junto dos investidores, aumentando assim a sua atratividade. As principais plataformas consideram o pré-financiamento um componente essencial da sua sustentabilidade e do seu crescimento, em particular quando estão em causa investimentos de maior dimensão e qualidade. Além disso, a operacionalização do modelo de empréstimo acarreta alguns desafios jurídicos relacionados com a constituição e execução de garantias reais, quando estão em causa múltiplos investidores, por exemplo.

\section{Implicações do RE crowdfunding para o setor imobiliário}

O RE crowdfunding "democratiza" o acesso ao investimento imobiliário. Atrai pela oportunidade de investimento com pequenos montantes, pelo maior detalhe e transparência da informação relativa ao projeto, pelos custos de acesso mais baixos (desintermediação de consultores financeiros e outros prestadores de serviços da área imobiliária) e, claro, pelos retornos esperados mais atrativos.

A maior transparência (ou menor opacidade) destas operações é atrativa tanto para investidores como para promotores, em alternativa a outras

Figura $3 \triangleright$ Estrutura básica das operações de RE Debt Crowdfunding

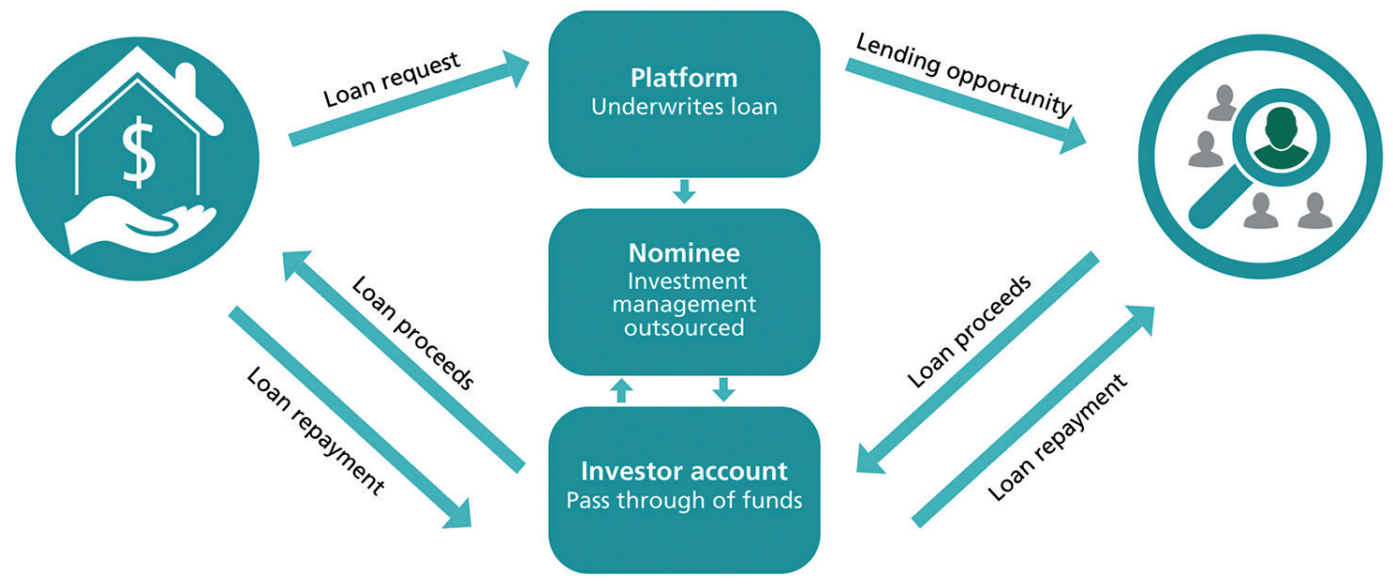

Fonte: O'Roarty (2016), p. 24 
fontes de financiamento. Os investidores recebem relatórios detalhados sobre o desempenho de cada investimento individual, enquanto os promotores beneficiam de um preço mais transparente na dívida que contraem ou no capital que angariam. Com efeito, a prazo, em função da relevância que estas plataformas possam vir a ter no mercado, é previsível que as fontes de financiamento tradicionais reajam e passem a disponibilizar soluções mais transparentes, com pricings e retornos mais comparáveis e/ /ou licitações mais competitivas.

No entanto, o mercado de RE crowdfunding também apresenta diversas deficiências. Desde logo, o fecho da transação só pode acontecer se a totalidade do capital solicitado for angariado, o que constitui um entrave para investidores e promotores com investimentos de maior dimensão.

Além disso, o mercado de RE crowdfunding não é ainda diretamente comparável com a indústria de CRE (comercial real estate), devido à sua dimensão reduzida e escopo consideravelmente mais estreito. De acordo com O'Roarty (2016), não é ainda possível comparar valores investidos via crowdfunding com os aplicados em fundos imobiliários, desde logo devido à discrepância dos montantes envolvidos e ao histórico dos diferentes instrumentos. Da mesma forma, os riscos e os retornos projetados, relativos a diferentes tipos de investimento em $\mathrm{RE}$ crowdfunding, diferem. Investimentos em dívida sénior, garantidos pela propriedade subjacente, apresentam um risco relativamente baixo para os investidores, uma vez que oferecem um alto grau de proteção de capital, em comparação com dívidas subordinadas e investimentos de capital, com menor proteção ao capital, mais risco, e por isso mais expostos à volatilidade dos preços ${ }^{15}$.

Para terminar, a fraca ou nula liquidez que estas aplicações financeiras apresentam, para o investidor que queira reaver o seu investimento fora das condições definidas ${ }^{16}$, constitui um outro entrave, que pode ser solucionado, em parte, com a criação de um amplo mercado secundário ${ }^{17}$. A possibilidade de posterior negociação dos valores mobiliários emitidos pelo beneficiário, através da criação e gestão de um mercado secundário organizado, permitirá que os investidores obtenham maior liquidez para o seu investimento, explorando mais rapidamente oportunidades de mais-valias e tornando também mais apelativas as ofertas, pela possibilidade de transação imediata, mitigando o seu risco.

\section{Conclusões}

O alcance da internet e a sofisticação tecnológica das plataformas existentes, a par com os baixos custos de transação, rapidamente vieram mostrar ao mundo que o crowdfunding não é mais uma moda passageira ou uma tendência dos novos tempos (onde imperam as redes sociais e as plataformas digitais), mas antes algo que veio para ficar ${ }^{18}$ e que pode vir a tornar-se um concorrente sério dos instrumentos de financiamento tradicionais, caso os principais intermediários financeiros que os fornecem (onde se incluem os bancos e a indústria dos fundos de investimento e de capital de risco) não consigam incorporar no seu modelo de negócio a inovação e as virtualidades tecnológicas do financiamento participativo (Montgomery, Squires \& Syed, 2018).

As plataformas de RE crowdfunding despertaram a atenção do público investidor (ou aforrador) para os méritos do investimento imobiliário e dos promotores imobiliários, para a facilidade e transparência no acesso a capital.

Com efeito, perante a inexistência de opções de aplicação de capital interessantes junto dos canais tradicionais, estas plataformas aproveitaram o apetite de pequenos investidores não qualificados que procuram exposição à dívida e investimentos de capital no setor imobiliário e, consequentemente, proporcionaram também maior acesso a capital para promotores imobiliários que estavam arredados do canal de financiamento bancário ${ }^{19}$ (Kim \& Hann, 2018), sendo que a concretização sustentada e bem-sucedida destes ciclos de investimento, satisfazendo promotores e investidores, gerará um círculo virtuoso difícil de romper.

O RE crowdfunding está por isso a conseguir capitalizar novos investimentos imobiliários, em vez de os canibalizar. Ainda assim será importante perceber, em função do impacto do crowdfunding, a reação dos instrumentos tradicionais de financiamento imobiliário (onde se incluem bancos e fundos de investimento), perspetivando-se, a prazo, o surgimento de ofertas mais transparentes, acessíveis e flexíveis.

Do ponto de vista macroeconómico, pode igualmente contribuir para minimizar alguma especulação imobiliária (em particular em mercados onde a oferta imobiliária seja escassa devido à falta de financiamento para desenvolver novos projetos) e o aparecimento de crises bancárias sistémicas (Montgomery, Squires \& Syed, 2018), por via da menor participação e exposição dos bancos a projetos imobiliários de grande dimensão (a par com maiores mitigadores de riscos) e partindo do pressuposto de que os capitais aplicados via crowdfunding são capitais próprios dos seus investidores, não sendo propriamente consequência de contração de dívida, contribuindo também dessa forma para um sistema financeiro com menores riscos de contágio e por isso menos instável. 


\section{Notas}

1 Por consulta aos quadros de setor, disponibilizados na Central de Balanços do Banco de Portugal em https:// www.bportugal.pt/QS/qsweb/Dashboards (acedido em 27nov18).

2 Somatório de todos os recursos controlados por uma entidade sob a forma de bens e direitos, a partir dos quais se esperam influxos de caixa no futuro. Compreendem ativos correntes e não correntes.

3 Os investidores de capital de risco ( $v$. g., private equity) e de fundos altamente especulativos ( $v$. g., hedge funds) tornaram-se particularmente ativos nesse mercado nesse período.

4 As modalidades de crowdfunding debt e equity (ver detalhes das várias modalidades existentes no Quadro 1) são alvo de regulamentação adicional específica através do Regulamento CMVM n.0 1/2016, de 5 de maio, tendo também ficado incumbida a CMVM da sua supervisão e sanção.

5 https://eu.usatoday.com/story/dispatches/2014/04/16/ hard-rock-hotel-palm-springs-crowd-funding/7789073/ (acedido em 24nov18).

6 https://www.wsj.com/articles/chinas-wanda-group-raises-805-million-in-crowdfunding-push-1434687631 (acedido em 24nov18).

7 Estes contratos de depósito caraterizam-se por ter como base um acordo entre duas ou mais partes em que se confia a uma (geralmente um banco, mas pode ser um terceiro) a guarda e posterior restituição de bens móveis (valores mobiliários, numerário, títulos de crédito), consignados a um fim específico. No final do prazo (ou em face de um evento previamente acordado) procede-se à sua entrega a um terceiro ou à restituição ao depositante.

8 O crowdfunding funciona neste caso também como instrumento de marketing e screening de mercado, auxiliando os empresários a testar a popularidade do seu produto/serviço, ao mesmo tempo que asseguram financiamento para a empresa.

9 A par com o debt (ou lending) crowdfunding existe ainda o peer-to-peer $(P 2 P)$ lending. Enquanto no debt crowdfunding o objetivo é atingir um montante para financiar determinado projeto angariado junto de múltiplos investidores, no $P 2 P$ lending o objetivo passa por recorrer a uma plataforma online que se encarrega de reunir financiadores e tomadores de crédito que queiram realizar empréstimos diretamente entre si.

10 As plataformas de crowdfunding tentam rentabilizar o seu know-how tecnológico através do fornecimento de soluções de software como serviço. Por exemplo, as plataformas CrowdStreet.com, CrowdEngine.com e Katipult. com consentem que os promotores imobiliários instalem os seus próprios portais de marca, nestas plataformas, permitindo que alavanquem a sua própria base de investidores e exerçam controlo sobre a sua recetividade ao investimento, abrindo-se a um mercado mais amplo.

11 Plataformas como thesyndicate.vc e angelsden.com listam oportunidades de investimento nas quais investiram, por meio de redes online e offline. Os business angels fazem o pré-rastreio dos investimentos e realizam a sua due diligence de oportunidades e, em seguida, abrem o investimento nos mesmos termos ao grande público, através de um portal de crowdfunding.

12 Por exemplo, no Reino Unido, o requisito regulatório para garantir que os investimentos não sejam contaminados pelo risco de insolvência da plataforma resulta geralmente na afetação da responsabilidade da gestão das participações a uma nominee, empresa legalmente independente da plataforma.

13 Modelo de negócio da plataforma housers.com, em que por detrás de cada compra de um imóvel há uma sociedade que é constituída, o que significa que o investimento num imóvel, listado na plataforma, por um qualquer investidor, se traduz na aquisição de uma participação societária da sociedade que o detém ou na concessão de um financiamento a essa sociedade.

14 É o caso das portuguesas izilend.com e portugalcrowd.pt. Como exemplo, na portugalcrowd, de acordo com informação recolhida na sua página institucional http:// portugalcrowd.pt/wportcrowd/url/page/como-funciona (acedida a 02jan19), cada investidor, através de um contrato de mútuo, empresta diretamente ao proprietário do imóvel. Há uma rentabilidade preestabelecida para cada oportunidade: a partir de $6 \%$ ao ano, rentabilidade que é paga todos os meses. Cada imóvel é dado como garantia para o cumprimento do empréstimo.

15 Enquanto estes últimos investimentos oferecem retornos mais elevados, tem havido alguma preocupação por parte dos reguladores sobre se os riscos são adequadamente explicados aos potenciais investidores e se a exposição ao risco é apropriada para os investidores de retalho.

16 Por exemplo, o reembolso será feito via alienação do imóvel no final de um dado prazo, definido previamente.

17 De acordo com Catarino (2017), um mercado secundário dificilmente terá, no atual enquadramento legislativo, cobertura legal na generalidade dos Estados da União Europeia, como Portugal, dada a reserva legal de constituição de mercados regulados para valores mobiliários.

18 Em 2013, o Banco Mundial, no seu relatório intitulado Crowdfunding's Potential for the Developing World, estimava que o mercado global de crowdfunding em 2025 poderá chegar próximo dos 100 mil milhões de dólares, o dobro da indústria de capital de risco à data.

19 Em particular, as PME que pretendem desenvolver projetos imobiliários, o investidor individual que pretende dedicar-se ao mercado de arrendamento ou mesmo os cidadãos que pretendem desenvolver um projeto imobiliário comunitário continuam a registar restrições no recurso a fontes tradicionais de financiamento (O'Roarty, 2016).

\section{Referências bibliográficas}

Agarwal, S., Genay, H., \& McMenamin, R. (2010). Why aren't banks lending more? The role of commercial real estate (Chicago Fed Letter, 281) Chicago: The Federal Reserve Bank.

Bailey, J. P., \& Bakos, Y. (1997). An Exploratory Study of the Emerging Role of Electronic Intermediaries. International Journal of Electronic Commerce, 1(3), 7-20. 
Baldwin, A. (2017). New developments in real estate financing. Economic Affairs, 37(1), 141-145.

Banco Mundial (2013). Crowdfunding's Potential for the Developing World. Washington, DC: Info Dev, Finance and Private Sector Development Department.

Belleflamme, P., Lambert, T., \& Schwienbacher, A. (2014). Crowdfunding: Tapping the Right Crowd Journal of Business Venturing, 29(5), 585-609. doi: 10.1016/j.jbusvent.2013.07.003

Catarino, L. (2017). Crowdfunding e crowdinvestment: o Regresso ao Futuro? Coimbra: Publicações CEDIPRE Online 32. Disponível em: http://www.cedipre.fd.uc.pt

Cole, M. (2015, junho 24). Could Asia's Richest Man Make REITs Obsolete? Forbes Asia. Disponível em: https://www.forbes.com/sites/michaelcole/2015/06/24/could-asias-richest-man-make-reits-obsolete/\#387319b13e93

Cowen, J. (2016). A study on the history and functionality of real estate crowdfunding. Joseph Wharton Scholars. University of Pennsylvania. Pennsylvania. Disponível em: https://repository.upenn.edu/joseph_wharton_scholars/19/ (acedido em 24mar18)

Flood, C. (2013, maio 19). Is ground rent investment built on solid foundations?. Financial Times. Disponível em: https://www.ft.com/content/affb1b8cbbe4-11e2-a4b4-00144feab7de

Howe, J. (2006, janeiro 6). The rise of crowdsourcing. Wired Magazine. Disponível em: https://www. wired.com/2006/06/crowds/
Jenik, I., Lyman, T., \& Nava, A. (2017). Crowdfunding and Financial Inclusion (CGAP Working Paper Março 2017). Washington, DC: CGAP.

Kim, K., \& Hann, I. (no prelo). Disillusion of the Democratization of Finance: Housing Prices, Collateral, and Online Crowdfunding. Information Systems Research, doi: 10.2139/ssrn.2334590

Manaktala, N. (2015). Democratising Finance: Digital Real Estate Investing Demystifed. Deal Index.

Marchand, F. (2016). Equity-based Crowdfunding Real Estate Markets, P2Report. Delft: Faculty of Architecture and the Built Environment, Delft University of Technology.

Montgomery, N., Squires, G., \& Syed, I. (2018). Disruptive potential of real estate crowdfunding in the real estate project finance industry: A literature review. Property Management, 36(5), 597-619.

O'Roarty, B. (2016). Real Estate Crowdfunding: Gimmick or Game Changer? Inglaterra: Investment Property Forum Research.

Ordanini, A., Miceli, L., Pizzeti, M., \& Parasuraman, A. (2011). Crowd-funding: Transforming Customers into Investors Through Innovative Service Platforms. Journal of Service Management, 22(4), 443-470.

Schwienbacher, A., \& Larralde, B. (2010). Crowdfunding of Small Entrepreneurial Ventures. In D. Cumming (Ed.), The Oxford Handbook of Entrepreneurial Finance. Oxford: Oxford University Press.

Wilkinson, S., \& Reed, R. (2008). Property Development. Oxford e Nova Iorque: Routledge.

Recebido a 31/10/2018. Aceite para publicação a 28/01/2019

Miguel Neves Matias (miguel.matias@ymail.com). Professor adjunto convidado. Escola Superior de Tecnologia e Gestão. Instituto Politécnico de Leiria. Morro do Lena, Alto do Vieiro, 2411-901 Leiria, Portugal. 


\title{
ENTRE AS PRÁTICAS E AS POLÍTICAS. O PROGRAMA HABITAR PORTO BETWEEN PRACTICES AND POLICIES. PROGRAMME HABITAR PORTO
}

\author{
Aitor Varea Oro, Ana Pinheiro e Mariana Almeida \\ Habitar Porto
}

\begin{abstract}
Resumo
O artigo toma por base o trabalho do programa Habitar Porto, um agente do terceiro setor que, para democratizar o acesso à produção de habitação, procura inserir as respostas criadas na sociedade civil dentro de um enquadramento institucional estável. Este passo do "coletivo" ao "público" permite tornar as soluções sustentáveis no tempo e acessíveis a uma maioria, mas obriga a um constante e difícil trabalho realizado entre o dentro e o fora das instituições. A partir da reflexão sobre o percurso do Habitar Porto nos últimos dois anos, perspetivado a partir do trabalho de autores que analisaram os processos de articulação e inovação social, o texto visará ilustrar de que maneira concreta acontecem estes processos e apontará para as oportunidades e resistências que devem ser objeto de reflexão para tornar estas iniciativas mais eficazes.
\end{abstract}

Palavras-chave: administração pública; sociedade civil; políticas de habitação; ilhas do Porto

\begin{abstract}
The article is based on the work of the programme Habitar Porto, a third sector agent that, in order to democratize access to housing production, seeks to insert the responses created in civil society within a stable institutional framework. This move from "collective" to "public" allows solutions to be sustainable over time and accessible to a majority, but it requires a constant and difficult work done between the inside and outside the institutions. Based on the reflection on the course of Habitar in the last two years, which will be framed on the work of authors who analyzed the processes of articulation and social innovation, the text will illustrate how these processes take place and will point out some opportunities and resistances that should be addressed in order to make these initiatives more effective.
\end{abstract}

Keywords: public administration; civil society; housing policies; Porto islands

\section{O problema da habitação}

Housing is seen as the domain of experts like developers, architects, or economists (...) but the crisis is deeper than that. We see housing in a wider perspective: as a political-economic problem. The residential is political - which is to say that the shape of the housing system is always the outcome of struggles between different groups and classes. (Madden \& Marcuse, 2016, p. 4)

Contexto atual. Como alargar os direitos sociais?

O acesso a uma habitação condigna é um direito consagrado pela Constituição portuguesa, tal como acontece com o direito a uma assistência sanitária universal e gratuita. Porém, dificilmente conseguiremos a efetivação do primeiro sem dotá-lo de infraestruturas semelhantes às que sustentam o segundo e da consciência pública que permite defendê-las.

Coloca-se então uma dúvida processual. Infraestruturas para dar resposta ao direito, ou consciência cidadã para defender a existência das mesmas? A pergunta sobre "por onde começar" para alterar (e articular) as respostas públicas ao dispor da sociedade é uma pergunta já clássica, perfeitamente sintetizada em palavras de Nuno Portas:

É uma típica questão de todas as fases de transição: a de saber por onde é que se começa. Se se começa pelos decretos e pelas 
leis ou se se começa por processos que alterem as condições e as relações de força, para que as leis sejam já a recolha dessas experiências e a sua necessária consolidação, no caso de serem boas e de a relação de forças ser favorável. (Portas, 1986, p. 637)

Um caso específico e umas perguntas mais abrangentes

O artigo toma por base o trabalho do Habitar Porto, uma iniciativa dinamizada por uma associação sem fins lucrativos que, partindo do pressuposto de que para diversificar o leque de beneficiários da habitação precisamos de diversificar o tipo de promotores, visa facilitar aos proprietários o acesso ao mundo profissionalizado da reabilitação urbana.

Pois que o Habitar não pretende apenas mostrar que fazer diferente é possível, mas também contribuir para que as respostas sejam sustentáveis no tempo e acessíveis a uma maioria suficiente; o programa trabalha com a convicção de que não há resposta satisfatória se ela não se insere dentro de um enquadramento institucional estável.

Este desejo de passar do "coletivo" ao "público" faz com que o Habitar trabalhe em articulação com diferentes níveis da Administração (Juntas de Freguesia [JF], Divisão Municipal de Urbanismo [DMU] e Instituto de Habitação e Reabilitação Urbana [IHRU]). As oportunidades e os constrangimentos deste caso específico permitem responder a questões mais abrangentes.

A partir da reflexão sobre o percurso do Habitar nos últimos dois anos, o texto visará perceber quais são os contributos da sociedade civil para a matéria em discussão, que oportunidades e resistências se identificaram, e que papel tem ou poderia ter o poder público para permitir a mudança de paradigma necessária na área da habitação.

Tornar o problema público.

Breve enquadramento teórico

"In an unequal society, the people who have the means to start projects are the elites. 'No' is often the only thing that the relatively powerless are able to say that can be heard by those in power." (Madden \& Marcuse, 2016, p. 188)

\section{Do protesto à proposta}

Um dos fatores que mais se destacam no atual debate público é a pressão cidadã e mediática à volta da dificuldade de acesso a uma habitação condigna. Não é descabido afirmar que esta crise do alojamento é decorrente de um conjunto de medidas de liberalização do mercado de habitação, que tiveram o seu auge nos anos pós-troika.
Esta situação conduziu a um crescente descontentamento em que o perigo reside na descredibilização de instituições e setores profissionalizados e na sua substituição por formas de participação direta da sociedade civil que, em certas manifestações de voluntariado ou empreendedorismo, terminam por branquear a retirada do poder público.

Contudo, seria erróneo tentar deslegitimar este descontentamento. É necessário perceber as suas razões e canalizá-lo para a construção de soluções justas e eficazes, a fim de promover uma transformação das instituições tal que consiga abordar problemas que, na atual configuração do poder público, tem dificuldades em resolver.

\section{A harmonia dos elementos dissonantes}

O papel-chave que o Estado tem na criação das regras vigentes no campo da habitação é reconhecido por autores como Bourdieu (2000), que descreve como os atores com mais peso (empresas, fundos de investimento) tentam (e conseguem) influenciar o poder público para tornar as normas mais favoráveis às suas caraterísticas próprias e adquirir posições de vantagem.

Porém, isto não é o mesmo que produzir alterações tendentes para a inovação institucional, tarefa para a qual, como defende Cels (2012), a Administração Pública não está bem equipada. Segundo Granovetter (1973), os atores que habitam na periferia do sistema são os mais capazes para assumir riscos e espalhar a inovação a segmentos mais abrangentes.

Autores como Laclau (2005) ou Latour (2005) defendem que este tipo de transformações requer re-ensamblar um conjunto a partir dos seus fragmentos, juntando demandas que antes estavam isoladas entre si. E isto exige refletir sobre alguns atores-chave com base nas suas identidades e regras, próprias ou atribuídas, que constroem para si entendimentos muito diferentes do problema.

Um ator (fr)ágil. Técnicas para a re-ensamblagem social ${ }^{1}$

É neste contexto que se enquadra a ação do Habitar, que pretende resolver as necessidades de alojamento dos inquilinos cuidando dos interesses dos proprietários, mobilizando financiamento disponível para reabilitação urbana a custos controlados e criando, com isto, trabalho qualificado para os profissionais. $^{2}$

Surgida da sociedade civil, a iniciativa tem no seu pouco peso institucional e na dificuldade para definir, de maneira consensual, a sua missão ("promover uma transformação social a partir da habitação") a sua maior força e a sua maior fraqueza, motivos pelos quais o programa se esforça 
por definir novos termos para o debate, balizando a sua ação a partir de três princípios:

- Encontrar fontes de legitimidade que sejam capazes de congregar maiorias sociais abrangentes. Por exemplo, falar em "direito à cidade" ou no processo "SAAL" atrai segmentos muito reduzidos da sociedade. Porém, falar em "habitação a preço justo" ou fazer um paralelo entre a habitação e a saúde mobiliza um conjunto mais alargado de atores, que é o essencial para poder trabalhar.

- Invocar agentes que normalmente não participam da discussão ou que o fazem com base em identidades atribuídas por terceiros. Utilizar os espaços de socialização como fóruns privilegiados de debate (em vez dos formatos técnicos ou académicos) ou definir os proprietários (em vez dos inquilinos) como a principal massa crítica a mobilizar para promover habitação a custos controlados contribui para colocar o problema na agenda pública de uma maneira mais eficaz, criativa e inclusiva, ultrapassando falsos dilemas.

- Criar espaços onde as coisas se possam fazer e dizer de outra maneira. A ação dentro dos moldes de cada um dos atores-chave (técnicos, inquilinos, proprietários, instituições) impõe uns limites ao debate que, por vezes, só é possível ultrapassar criando áreas de interação entre parte destes atores, onde a falta de regras estabelecidas seja colmatada pelo bom senso, potenciando assim as pontes em vez dos muros.

Ao longo das próximas duas epígrafes, vamos pormenorizar a maneira específica como o Habitar tem tentado promover uma formulação diferente dos problemas, capaz de identificar curto-circuitos no atual funcionamento do sistema, formular outra geografia para os problemas, atrair parceiros capazes de materializar soluções alternativas e promover um enquadramento institucional estável para as mesmas.

\section{Nada nasce com a sua própria forma.} Cronologia do programa

O Habitar inicia a sua atividade em abril de 2016, com base nos princípios referidos e ao abrigo de um protocolo com a Junta de Freguesia do Bonfim (JFB), considerado o ator essencial para outorgar legitimidade à iniciativa e ancorá-la à realidade do terreno. Enquadrada numa lógica de recursos escassos, esta aliança dura até à atualidade com benefícios mútuos para ambas as partes.

A parceria formalizou-se com o formato de um gabinete de atendimento técnico, uma prática tipificada que podia ser aceite pela administração pública e que permitia ao Habitar auscultar as necessidades da população numa lógica de proximidade. Com o objetivo de exponenciar tanto os benefícios do formato como o abrigo institucional, desenvolveram-se duas estratégias:

- Por um lado, o recurso à comunicação social, divulgando o problema em termos simples e inclusivos, o que serviu para atrair o maior número possível de utentes ao gabinete, exponenciando aquilo que estava ao abrigo do protocolo. O discurso lançado, que permanece inalterado, foi o seguinte: os problemas de um proprietário que não pode reabilitar a sua propriedade, de um inquilino que não encontra habitação com rendas acessíveis e de um profissional da construção que não encontra trabalho ou que gostaria de desenvolvê-lo dentro de outros moldes não são três problemas separados, mas três sintomas do mesmo problema: as ferramentas existentes para a promoção da cidade não alcançam uma maioria social (e, portanto, devem ser democratizadas).

- Por outro lado, o aproveitamento do abrigo institucional e mediático para alargar a rede e desenvolver práticas que, sendo essenciais para a construção social do problema, não cabiam nos desígnios consagrados pelo protocolo inicial. O objetivo era crescer em capacidade operacional, não tanto a partir da afinidade ideológica ou setorial, mas sim a partir de práticas concretas que mobilizassem interesses de parceiros estratégicos que estariam disponíveis para trabalhar, alargando as áreas de influência do programa. Desta maneira foi possível ir construindo um domínio de interesses sobre os quais valia a pena trabalhar e que, embora não conduzissem à construção imediata de habitação, faziam parte da construção de uma solução mais sustentável no longo prazo.

Práticas emergentes

A duração do primeiro protocolo do Habitar foi de 6 meses, insuficientes para realizar projetos de arquitetura, menos ainda para materializá-los, com as agravantes de que o único programa existente na altura era o Reabilitar para Arrendar (RpA) e de que a dificuldade não residia apenas no encaminhamento para os programas, mas, acima de tudo, no acompanhamento dentro dos mesmos.

Neste sentido, cabe ressalvar uma primeira dificuldade estruturante: a dificuldade de entregar projetos de arquitetura a gabinetes privados a partir de uma estrutura que, sendo do terceiro setor, trabaIha ao abrigo do poder público. É esta uma questão de difícil resposta, cuja solução estará condicionada a um reposicionamento dos atores compatível com 
as reorganizações possíveis dos campos simbólico e burocrático.

A consciência de precisar de mais margem para resolver estes problemas estruturantes fez com que este tempo fosse utilizado para desenvolver um conjunto de práticas que, fora da parceria inicial com a JFB, mas sem objeção da mesma, permitiram alargar o conjunto de parceiros interessados em prorrogar o protocolo e alterar o seu conteúdo. Podemos elencar brevemente um conjunto de princípios e estratégias utilizadas.

1. A proximidade como regra. O abrigo da JFB permitiu que equipas mistas de arquitetos e de educadoras sociais visitasse as casas dos utentes do Gabinete de Ação Social para realizar avaliações físicas e sociais. Mesmo sem expectativas de intervenção, auscultar o terreno foi importante para conhecer as carências e desenvolver uma gramática comum às duas disciplinas, evitando que os arquitetos se tornassem educadores sociais e vice-versa.

2. Desenvolvimento de estratégias coletivas. Os atendimentos no gabinete revelavam que, em certas ocasiões, um problema individual só podia ser resolvido a partir de uma solução coletiva. Esta circunstância, que decorre das exigências dos programas públicos existentes ou, face à sua ausência, da necessidade de adquirir uma posição de maior força perante os atores dominantes do mercado, pode ser explicada com dois exemplos:

a) O pedido de uma utente de resolver a falta de uma instalação sanitária na sua casa não podia resolver-se a partir dos programas existentes, que exigiam a reabilitação integral do edificado, neste caso, toda a "ilha". Assim, foi necessário trabalhar com a totalidade dos moradores para perceber a sua recetividade para propor aos proprietários uma candidatura ao $\mathrm{RpA}$, bem como a sua capacidade de atualizar a renda, com o intuito de permitir financiar as obras e garantir a manutenção futura.

b) O inflacionamento dos preços no Bonfim, visível a partir de 2016, fez com que um grande número de famílias que desejava viver na freguesia não pudesse concorrer com os grandes agentes do mercado. Perante esta situação, resolveu-se unir os vários pedidos recebidos no gabinete $\mathrm{e}$ passar do individual ao coletivo. A desadequação e o desinteresse das estruturas cooperativas tradicionais evidenciaram a necessidade de desenvolver novas estruturas produtivas mais permeáveis ao contexto socioeconómico atual.
3. Dimensão formativa. Um dos melhores exemplos do que se quer dizer com "promover uma transformação social a partir da habitação" é a acumulação de experiência, a produção e transmissão de conhecimento, especialmente criando novas redes que permitam ultrapassar os constrangimentos das atuais estruturas produtivas (que materializam as encomendas) e de mediação (que lhes dão forma). Este tipo de práticas exige a participação de entidades com capital social, simbólico e de conhecimento, e podem ser ilustrados com dois exemplos:

a) Formação de equipas técnicas. Apesar de serem públicos muito diferentes, rapidamente se percebeu que proprietários, inquilinos ou, inclusivamente, instituições do terceiro setor com interesse em matéria de habitação acessível tinham pedidos recorrentes que poderiam ser um fator aglutinador: mão de obra qualificada não especulativa. Graças à mediação da junta, organizaram-se iniciativas que visavam qualificar os utentes do CICCOPN em formação prática em contexto de trabalho.

b) Alargar o campo da boa arquitetura. Em 2017, a empresa de gesso cartonado Pladur organizou o seu $27 .{ }^{\circ}$ concurso ibérico de arquitetura, que congrega anualmente dezenas de faculdades de Espanha e Portugal. Para evitar uma romantização do problema das "ilhas" (que foi o caso de estudo proposto naquela edição), iniciou-se uma parceria que visou utilizar as faculdades como meio de difusão de umas bases que convidavam a pensar na realidade socioeconómica da ilha como ferramenta de projeto e o prémio como uma maneira de incitar este tipo de abordagem disciplinar.

\section{Do terreno aos terrenos}

Em março de 2017 o programa é alargado em duas direções: por um lado, no âmbito territorial (a Junta Freguesia de Campanhã [JFC] junta-se à rede de parceiros); por outro, no âmbito administrativo, onde se começa a explorar o espaço "entre" na relação das JFB e JFC e a DMU. Esta situação permite multiplicar a permeabilidade entre instituições e território:

- Em primeiro lugar, porque a entrada de uma nova junta torna necessária a realização de um novo protocolo - o que permite incorporar de maneira oficial algumas das práticas marginais desenvolvidas à margem do protocolo durante a primeira fase. $O$ facto de essa junta e essa freguesia terem diferentes 
caraterísticas da do Bonfim permitiu que a leitura do protocolo fosse distinta em cada território, possibilitando ensaiar diferentes soluções e replicá-las quando bem-sucedidas.

- Em segundo lugar, porque o protocolo, tripartido, envolve a DMU. A entrada de um novo nível da Administração traz, como consequência, uma oportunidade - acresce uma camada técnica que não possuíam nem as juntas nem o Habitar - e um desafio conciliar linguagens e prioridades por vezes contraditórias, ainda que dentro do mesmo município.

Esta nova fase serviu para identificar um segundo problema estruturante: às vezes o problema não é cumprir os regulamentos (dos programas de financiamento ou dos projetos necessários para usufruir deles), mas sim as burocracias associadas (sendo estas, por vezes, um fator de exclusão dos cidadãos com menos competência técnica ou poder para adquiri-la).

Práticas consolidadas

Segundo o sociólogo Tomás R. Villasante (1989), existem três principais maneiras de articular as redes sociais: a "populista" (confluência da Administração com os Grupos Informais), a "ciudadanista" (confluência dos Grupos Formais e dos Grupos Informais) e a "gestionista" (confluência dos Grupos Formais e da Administração).

Com a assinatura do segundo protocolo e, incrementalmente (especialmente a partir das autárquicas de 2017), o Habitar começa a desenvolver uma prática ancorada no último grupo. Esta escolha não depende tanto da vontade (considera-se mais interessante a "ciudadanista") mas antes da necessidade objetiva, que pode sintetizar-se nas seguintes razões:

- Por um lado, considera-se o trabalho "no terreno" importante, mas a escuta de proximidade pode dar-se também em "outros terrenos" que são fulcrais para o cumprimento dos objetivos, como pode ser o campo burocrático (onde não faltam pessoas interessadas em mudar as práticas habituais).

- Por outro lado, chega-se à conclusão de que os proprietários com quem se trabalha ( $\mathrm{e}$, por extensão, os inquilinos) não desejam ativistas, mas antes projetos aprovados. Isto faz com que se sinta a necessidade de especializar e profissionalizar progressivamente o nosso trabalho.

- Além disso, começa-se a perceber que a dicotomia "ativistas" e "tecnocratas" é redutora. Interessa desenvolver uma atividade que ultrapasse os dois extremos, incorporando as razões que Ihes são subjacentes. Esta hipótese só é compatível com a profissionalização quando se está de maneira ativa nos vários terrenos.

Assim, decide-se deixar cair certas parcerias e incorporar o seu conteúdo em práticas vinculadas e veiculadas por atores institucionais com os quais seria possível traduzir as preocupações individuais para uma gramática comum que, quando materializada, poderá cristalizar em soluções mais eficazes e acessíveis a uma maioria.

Fatores externos, de natureza especialmente política, fazem com que o foco de ação comece a afunilar-se no caso específico das ilhas. A situação de emergência em que vivem estas populações e a incapacidade manifesta de dar resposta a todas as frentes faz com que se decida focar os contributos nesta frente.

As práticas descritas em seguida são consequência lógica do que foi descrito:

1. Arquitetos de família: Regulamentada por um contrato interadministrativo, com duração de dois anos, sem trocas económicas, entre a FAUP, a JFB e o Habitar. Esta iniciativa, que visa intervencionar situações agudas em casas de ilha, dá estabilidade, legitimidade e recursos a uma parceria informal desenvolvida previamente entre o Habitar (que proporcionava apoio técnico em forma de estudo prévio realizado pelos estagiários) e a JFC (que sinalizava os beneficiários e disponibilizava os recursos para as intervenções).

Este programa visa atingir três objetivos. Os dois primeiros são óbvios: dar melhores respostas aos beneficiários e ampliar a formação dos estudantes. O terceiro é mais estratégico: qualificar as intervenções do programa Casa Reparada Vida Melhorada (CRVM) (comum às duas JF e responsável pelas intervenções) criando uma ponte entre as prioridades da JF (o urgente: mitigar as penosas condições de vida dos fregueses em exclusão social) e as da CMP (o importante: garantir que as intervenções se enquadrem nos direitos urbanísticos e construtivos dos habitantes).

2. Diagnóstico socioespacial de 40 ilhas na ARU de Campanhã-Estação: Contrato público, entre a DMU e o Habitar, com duração de dois anos e com dotação orçamental que possibilita manter a presença nos terrenos. Este trabalho visa "conhecer e compreender as pessoas que habitam estes núcleos, nomeadamente a sua relação com a habitação, com o núcleo e com a envolvente, bem como as suas expectativas", e levantar 
"as estruturas edificadas, por forma a ser possível definir estratégias de intervenção, bem como a quantificação e avaliação dos custos das intervenções". ${ }^{3}$

O trabalho envolve um intenso trabalho de campo e um rigoroso tratamento de informação, com recurso a Sistemas de Informação Geográfica. Além dos objetivos descritos, este estudo tem duas valências estratégicas: por um lado, facilita a comunicação entre os diferentes níveis da administração local (grande parte da metodologia assenta nas aprendizagens na proximidade ensaiada no trabalho com a junta); por outro, consolida uma metodologia de análise territorial e de sistematização e produção incremental de informação de malha fina.

3. Concurso Pensar, Construir, Habitar. Iniciativa regulamentada por protocolos pontuais entre a JFC e o Habitar, que pretende fazer a ponte entre o património degradado e os programas públicos de reabilitação com foco nas rendas acessíveis. Esta prática, cuja segunda edição está a ser delineada no momento de escrita deste texto, pretende resolver as necessidades dos inquilinos cuidando dos interesses dos proprietários através de um processo aberto, transparente, onde os projetos são adjudicados com base em critérios de adequação.

O concurso configura uma plataforma que integra várias entidades públicas, com o objetivo de que entre concorrentes e proprietário não exista um simples caderno de encargos, mas antes uma ideia de cidade, o que divulga novas práticas entre os concorrentes. A primeira edição serviu para constatar que era possível mudar práticas (a DMU definiu critérios de apreciação das "ilhas", entidades morfológicas que não encaixam no PDM mas que encontram abrigo legal no RJUE, RJRU e RERU) ou testar programas (o IHRU utilizou as propostas para testar o programa $10^{\circ}$ Direito).

Identifica-se assim um terceiro problema estruturante: articular diferentes demandas (proprietários, inquilinos e instituições) é possível de maneira pontual. Mas fazer isto de maneira sustentada e incluindo, aliás, critérios multissetoriais (como por exemplo emprego ou saúde) requer inserir as ações num enquadramento institucional estável. Passamos, assim, do reino das práticas ao reino das políticas.

Figura $1 \triangleright$ Presença do Habitar nos diferentes terrenos
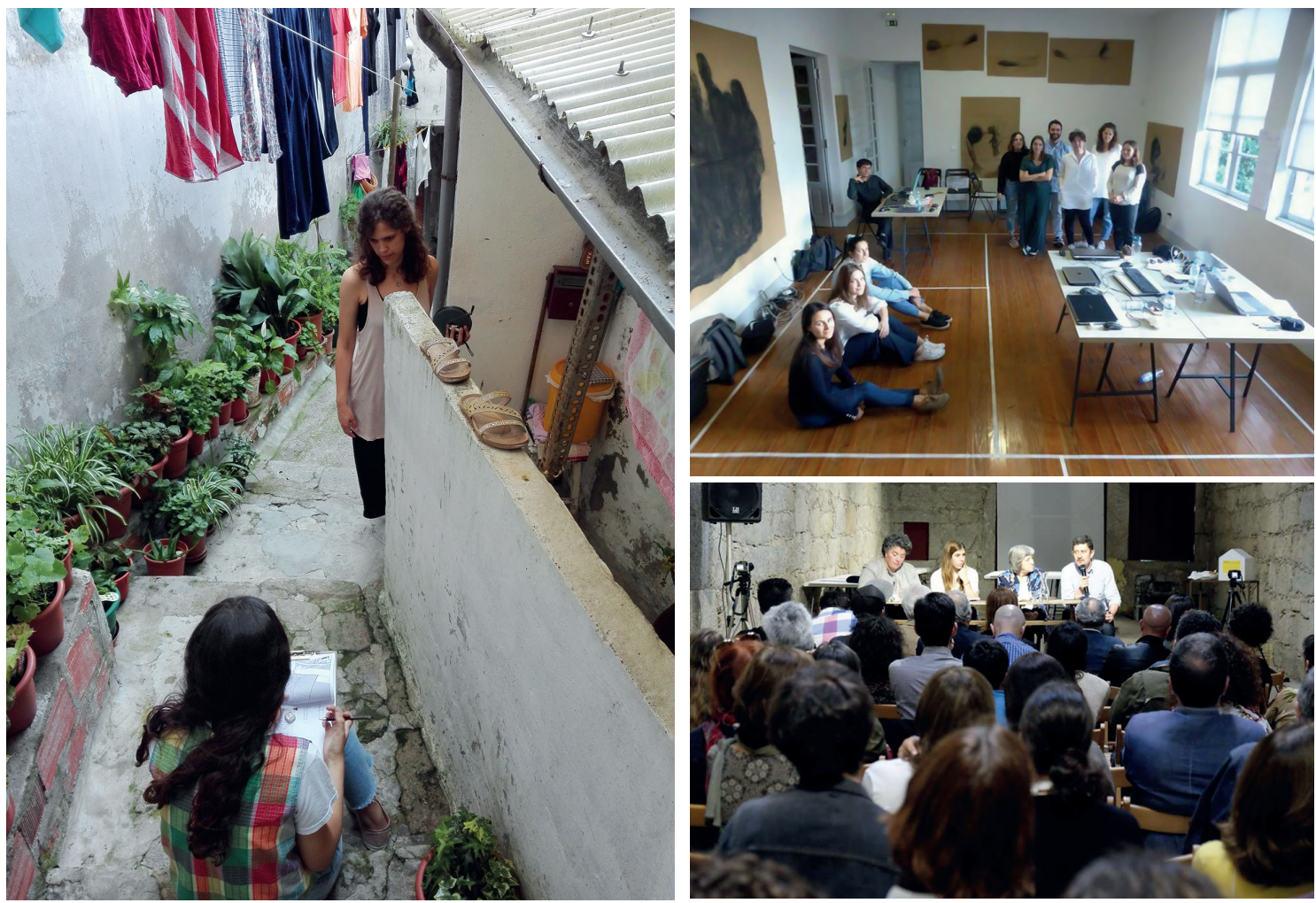

Fonte: Conjunto de imagens de autoria de Ana Pinheiro, Marta Paquete e Mira Fórum

E Sociológico

N. 34 (II Série, 2019)

pp. $61-70$ 
Figura $2 \downarrow$ Propostas de reabilitação de ilhas alavancadas pelas práticas do Habitar
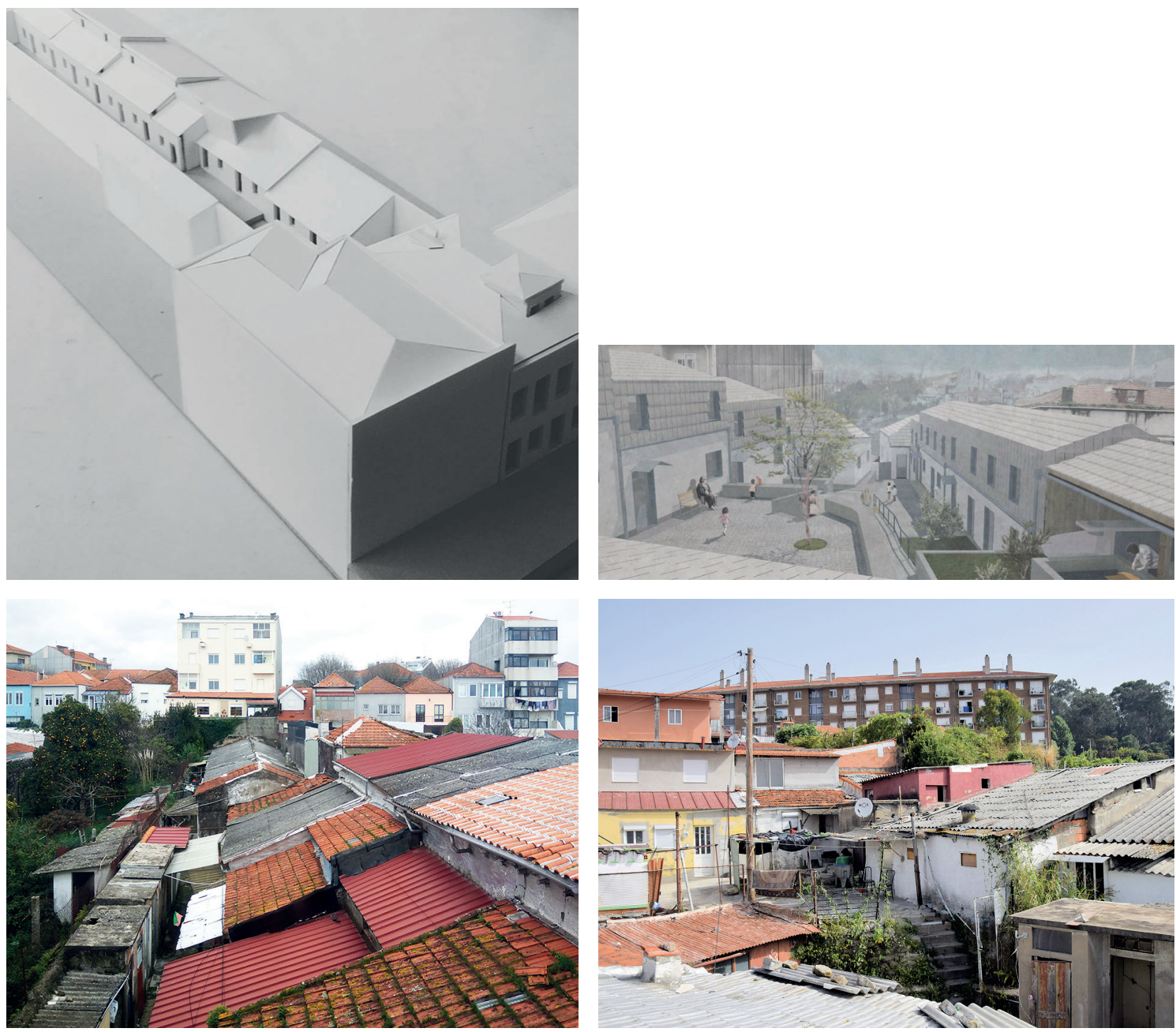

Fonte: Conjunto de imagens de autoria de Aitor Varea Oro, Merooficina, Bernardo Amaral e Tiago Delgado

\section{Das práticas às políticas}

By a successful innovation process we basically mean, first, a changed practice - a clear and tangible change from the way things were done in the past, and second, operational capacity to sustain the innovation as well as continued support from crucial stakeholders for the innovation. (Cels \& Nauta, 2012, p. 5)

Construir a forma da solução. Primeiros passos no Porto

No momento de escrita destas linhas, os responsáveis do Habitar e o Município do Porto chegaram a um acordo para expandir parte do programa, criando uma estrutura que preste apoio aos proprietários de "ilhas" nas freguesias do Bonfim e de Campanhã, articulando as práticas de todos os atores envolvidos e acumulando e transmitindo conhecimento para uma ação mais eficaz dos técnicos. ${ }^{4}$

Desta maneira, cria-se uma ponte entre os desígnios do Plano Estratégico de Desenvolvimento Urbano (PEDU) do Porto (criar novas ferramentas para permitir aos privados a dinamização do seu património) e as ferramentas criadas pelo Governo Central a partir da Nova Geração de Políticas de Habitação (NGPH) (nomeadamente, o programa 1. ${ }^{\circ}$ Direito). Esta ponte passa por reconhecer a necessidade de acompanhar os proprietários no processo de requalificação, aumentando o parque de habitação acessível no município.

$\mathrm{Na}$ base desta inovação, que consolidará as práticas identificadas pelo Habitar a partir de um contrato de cooperação por três anos entre o município e a FAUP (que faz parte da rede de parceiros criada), jaz um intenso trabalho de re-ensamblagem social, que tem por base uma atribuição diferente 
de papéis e um novo discurso à volta do problema das ilhas.

Importa destacar que, nesta tarefa de produção de sentido, não basta criar novos termos de debate. É imprescindível obter o consentimento de certos atores-chave que, por causa do seu prestígio e capital simbólico, legitimam as ideias lançadas. Para chegar a estes agentes, é imprescindível pensar em termos de práticas, atores e ações fora dos espaços consolidados.

Estes atores podem ser muito divergentes entre eles, falar para vários públicos e utilizar meios de expressão diferentes. De facto, é essencial que assim seja para que estas novas ideias ocupem o lugar do "bom senso". É possível dar alguns exemplos deste ascenso por capilaridade desde as necessidades sentidas no terreno até à sua entrada nas instituições:

- Em fevereiro de 2018, dois anos depois do lançamento do programa, o presidente da Câmara do Porto, em sede de audição parlamentar na Assembleia da República, afirmou que, através do Habitar, a cooperação entre Juntas e DMU persegue "trabalhar na capacitação técnica dos projetistas" e que se pretende "a partir das práticas concretas, desenhar políticas (...)".

- Em agosto de 2018, o jornal Porto, distribuído gratuitamente a todos os munícipes, afirma que o Habitar pretende:

"Simplificar ao máximo o processo de requalificação (com recurso a parcerias institucionais no apoio à obra), de modo a que os proprietários se sintam motivados a disponibilizar habitação a rendas acessíveis." (Finalmente descobriu-se o caminho para as ilhas, 2018.)

- Em outubro de 2018, o Jornal dos Arquitectos, distribuído gratuitamente a todos os membros da Ordem dos Arquitectos, destaca que o Habitar:

"... promovendo mecanismos de consulta de profissionais da arquitetura através do concurso de ideias e de diálogo, reforça o contributo dos proprietários privados para pensar as políticas públicas de habitação e ensaia coletivamente o desenho de soluções" (Oliveira, 2018).

Prever a forma dos problemas. Desafios e ferramentas a explorar

A solução descrita no ponto anterior cria uma resposta útil e pública à requalificação das ilhas, integrando, em simultâneo, parte das práticas perseguidas pelo Habitar desde o início da sua atividade (dando uma nova expressão, mais alargada, aos processos formativos). Contudo, o sucesso do programa estará condicionado a dois desafios que terão de ser resolvidos em simultâneo:

- Por um lado, a pressão social que, necessariamente, surgirá como resultado de uma prática que, inevitavelmente, não constituirá, por si só, uma resposta ao problema da habitação (porque o programa estará focado apenas nas ilhas, deixando fora outras tipologias e segmentos sociais; porque o problema é multissetorial, e não cingido unicamente à habitação, etc., ...).

- Por outro lado, a margem de ação para responder às contingências. A iniciativa nasceu ancorada na sociedade civil, mas cresceu articulando-se com os agentes institucionais. A sua formalização, que se traduz num contrato com direitos e obrigações para as duas partes, deixará inevitavelmente lacunas difíceis de contornar.

Aguardamos o desenvolvimento do futuro programa para perceber se os constrangimentos identificados podem ser atenuados pelo facto de a entidade promotora ser, nesta nova fase, uma entidade pública capaz de mobilizar outro tipo de articulações, discursos e legitimidades.

\section{Conclusão: regresso ao público}

A habitação não contribuirá para um desenvolvimento social equitativo se a sua promoção não for impulsionada institucionalmente e articulada com o resto de políticas públicas.

Ao longo do texto temos tentado ilustrar de que maneira esta ação pode ser progressiva, deve outorgar protagonismos aos vários níveis da administração e precisa, por vezes, de catalisadores externos. Estas espoletas, pertencentes à sociedade civil, têm menor peso do que as instituições (o que as impede de sustentar as ações), mas possuem mais agilidade (que as coloca em posição mais favorável para identificar e propor iniciativas mais próximas das dinâmicas locais reais).

Neste sentido, a principal conclusão é que a estratégia do Habitar prova que para implementar uma solução técnica nova é precisa a criação prévia de um novo espaço técnico e político, e que este novo espaço surge com o objetivo de articular um conjunto de demandas que eram não só heterogéneas, mas, acima de tudo, provenientes de atores anteriormente antagónicos. A grande dificuldade reside em institucionalizar estas práticas sem perder a conexão com o território.

Como viabilizar que o passo das práticas às políticas seja um salto e não um passo atrás? Tentaremos dar resposta da maneira mais pragmática possível referindo, por um lado, as ferramentas que já existem no atual quadro legislativo e, por outro, 
os princípios que, retirados da nossa experiência, podem tornar mais robusta a sua implementação.

a) Ferramentas existentes ou previstas na NGPH úteis para permitir a permeabilidade entre sociedade civil e poder público

Os desafios identificados parecem apontar a necessidade de capacitar o debate cidadão e de pôr as instituições ao serviço da cidadania. Parece importante aproveitar os espaços abertos pela NGPH e colmatar algumas das suas lacunas. O impacto das políticas de habitação nas populações é diretamente proporcional a três fatores:

- Por um lado, a produção e transmissão de informação de qualidade, transparente e acessível a cidadãos, investigadores, comunicação social e decisores políticos. É um passo incontornável para qualificar o debate público, balizar os termos da discussão e canalizar o descontentamento para ações produtivas. O programa Porta ao Lado parece incidir em alguma destas dimensões e seria positivo que a informação e o público-alvo fossem mais abrangentes.

- Por outro lado, o envolvimento da cidadania na promoção do espaço urbano, tanto nas dimensões que foram referidas neste texto como na produção de informação de qualidade, assente em lógicas de proximidade ou de participação. O programa Da Habitação ao Habitat parece ir nesta direção, embora pensemos que este tipo de estratégias não deve ficar cingido aos territórios marginais.

- Finalmente, é essencial articular a habitação com o resto das políticas públicas. As Estratégias Locais de Habitação parecem uma boa estratégia para passar das práticas isoladas às políticas integradas. Mas para isto é necessário continuar a tarefa de re-ensamblagem social descrita neste artigo, com o intuito de contornar a habilidade que o statu quo tem para neutralizar toda a tentativa de alteração.

b) Quais os rumos que podem guiar a NGPH para ultrapassar as resistências existentes

É muito difícil que se avance sem maior investimento do Estado, mas é impossível que o sentido do progresso esteja em relação direta com a sociedade para a qual se trabalha se não se envolvem os vários níveis da Administração e se não se utilizam todas as ferramentas para ancorar as políticas na cidadania. Neste sentido destacamos:

- É essencial o passo da ação coletiva à articulação pública, que permite desde a criação de novas instituições (como o programa de apoio aos proprietários das ilhas) até ao uso das mesmas com um uso comunicativo e não tanto punitivo ${ }^{5}$ (exponenciando assim a criação de novas "reputações" ensaiadas nas práticas consolidadas como Arquitetos de Família ou o concurso Pensar, Construir, Habitar).

- É fulcral a democratização da habitação: primeiro, da oferta e procura (como já se referiu, diversificar o leque de beneficiários da habitação através do estabelecimento de novos promotores); segundo, dos objetivos da reabilitação; e terceiro, dos termos da discussão. Falamos de uma relação dialética: é preciso aproximar as instituições das populações e é preciso aproximar as populações das instituições.

Em segundo lugar, é necessário afinar a arquitetura institucional. Como se tratou de provar ao longo do texto, as instituições têm tanto poder para implementar este tipo de inovações como constrangimentos para o fazer. Nesta circunstância, os atores com mais liberdade de ação podem estar nos vários terrenos e facilitar a permeabilidade entre atores. Perante este cenário, identificamos duas possíveis linhas de ação:

- Lutar contra as resistências que impedem que os agentes externos à Administração possam realizar o trabalho que Ihes cabe. Embora estas resistências sejam de todo o tipo (de recursos, contratuais, da própria cultura do terceiro setor), cingir-nos-emos a uma única: é necessário conseguir medir o impacto das práticas alternativas. Como afirmam Cels et al., $(2012$, p. 7), "the absence of such mechanism gives established organizations or practices in the public sector much more power to actively resist destruction in their fight for survival".

- Perceber que parte do trabalho a realizar pelas instituições está orientada não tanto para a construção de resultados, mas, antes, para a definição das estruturas em que os vários agentes se vão relacionar. Se é verdade, como parece afirmar a experiência, que a institucionalização das práticas emergentes envolve sempre o risco de colocá-las numa redoma, talvez seja necessário que o próprio poder público desenvolva regras e dinâmicas específicas que permitam a sobrevivência dos ecossistemas onde é possível dialogar entre o dentro e o fora do poder instituído.

$*$

A arquitetura é uma prática de caráter nitidamente coletivo. As pessoas sempre se juntaram para resolver os seus problemas em matéria de habitação e continuarão a fazê-lo. As fórmulas serão 
basicamente as mesmas: os tradicionais GTL ou as cooperativas de habitação encontram continuidade no gabinete de atendimento do Habitar e nas suas estratégias colaborativas.

O que muda é a maneira como se articulam os atores.

Cabe-nos trabalhar na criação de condições apropriadas para que as instituições sejam a garantia da estabilidade e da universalidade de acesso às soluções, da maneira mais apropriada para a natureza de cada território. A intervenção da sociedade civil é sempre desejável e necessária, mas pensamos que será um bom passo em frente tornar esta participação não apenas mais frequente como, principalmente, mais sustentável.

\section{Notas}

1 Uma aproximação mais pormenorizada ao trabalho do Habitar enquanto trabalho de ensamblagem social pode ser encontrado em Varea Oro \& Travasso (2018).

2 No momento de escrita destas linhas, o Habitar trabalha em quatro casos em diferentes fases (licenciamento, projeto de execução ou estudo prévio). Estas operações pretendem mobilizar cerca de $1100000 €$ de investimento público.

3 Extraído do contrato público entre o Município do Porto e o Habitar Porto.

4 Ver Varea Oro \& Vieira (2018).

5 Conceito retirado de Cortina (2017).

\section{Referências bibliográficas}

Bourdieu, P. (2000). Les structures sociales de I'economie. Paris: Seuil.

Cels, S., Jong, J., \& Nauta, F. (2012). Agents of change: Strategy and tactics for social innovation. Washington, D.C.: Brookings Institution Press.
Cortina, A. (2017). Aporofobia, el rechazo al pobre - Un desafío para la democracia. Barcelona: Ediciones Paidós.

Finalmente descobriu-se o caminho para as ilhas (2018, agosto). Porto, Retirado de http://www. porto.pt/assets/misc/img/noticias/Jornal\%20 Porto./Numero\%207/Jornal\%20Porto. \%20 n. $\%$ C2\%BA\%207\%20-\%20Vers $\%$ C3\%A30\%20 web.pdf

Granovetter, M. (1973). The Strength of Weak Ties. American Journal of Sociology, 78(6), 1360-1380.

Laclau, E. (2005). La razón populista. Buenos Aires/ México: FCE.

Latour, B. (2005). From realpolitik to dingpolitik or: How to make things public. In: B. Latour \& $P$. Weibel (Eds.), Making things public: Atmospheres and democracy (pp. 14-41). Cambridge, M.A.: MIT Press.

Madden, D., \& Marcuse, P. (2016). In Defense of housing. The Politics of Crisis. Londres: Verso.

Oliveira, I. (2018). O Futuro das Ilhas do Porto. Jornal Arquitectos. Retirado de http://www.jornalarquitectos.pt/pt/jornal/epicentros-pos-industriais/o-futuro-das-ilhas-do-porto

Portas, N. (1986). O processo SAAL: entre o Estado e o poder local. Revista Crítica de Ciências Sociais, 18/19/20, 635-644.

Varea Oro, A., \& Travasso, N. (2018). Assembling alternative practices: pushing the development of a new housing programme in Porto (Portugal). 8th International Conference on Building Resilience ICBR.

Varea Oro, A., \& Vieira, P. (2018). Programa Ponte. Uma abordagem sustentada às ilhas do Porto. Porto: PNUM proceedings.

Villasante, T. R. (1989). Retrato de Chabolista com piso: Análisis de redes sociales en la remodelación de barrios de Madrid. Madrid: Alfoz-CIDUR.

Aitor Varea Oro (aitorvarea@gmail.com). Habitar Porto. Rua Alves Redol, 407, 2.0 Dt.0, 4050-043 Porto.

Ana Pinheiro (anaacpinheiro@hotmail.com). Habitar Porto. Rua Alves Redol, 407, 2.0 Dt.0, 4050-043 Porto.

Mariana Almeida (mariana.ribeiro.almeida@gmail.com). Habitar Porto. Rua Alves Redol, 407, 2.0 Dt.0, 4050-043 Porto. 


\title{
ACESSO À HABITAÇÃO POR TODOS E PARA TODOS? PARADIGMAS E PARADOXOS DA ACTUALIDADE PORTUGUESA
}

\section{ACCESS TO HOUSING BY ALL AND FOR ALL? TODAY'S PARADIGMS AND PARADOXES IN PORTUGAL}

\author{
Sílvia Leiria Viegas \\ Centro de Estudos Sociais da Universidade de Coimbra (CCArq/CES-UC) e Faculdade de Arquitectura da Universidade \\ de Lisboa (GESTUAL/FA-UL)
}

\begin{abstract}
Resumo
O artigo versa sobre o acesso à habitação condigna em Portugal na contemporaneidade, por populações de médios e poucos recursos, de diferentes origens culturais e/ou étnicas, tendo em conta a transformação da sociedade urbana em curso. Viso sistematizar paradigmas habitacionais dominantes e seus impactes excludentes, a par de resistências locais, e, ao mesmo tempo, reconhecer os paradoxos de inclusão-exclusão inerentes aos ensaios governamentais na forja, socioespaciais e habitacionais. Para o efeito, recorro ao pensamento estruturante de autores teóricos como Foucault, Žižek, Lefebvre e Harvey, e às suas ideias-chave de governamentalidade, tolerância multicultural e direito à cidade. Concluo apontando as contradições do sistema neoliberal dominante conformando, simultaneamente, exclusão e esperança.
\end{abstract}

Palavras-chave: acesso à habitação; governamentalidade; tolerância multicultural; direito à cidade

\begin{abstract}
The article deals with the access to adequate housing in Portugal at the present time, by middle and low income populations, of diverse cultural and/or ethnic origins, taking into account the ongoing transformation of the urban society. I aim to systematise the dominant housing paradigms and their excluding impacts, together with local resistances and, at the same time, to recognise inclusion-exclusion paradoxes intrinsic to the forging of new governmental socio-spatial and housing experiments. To that end, I turn to the structuring thoughts of theoretical authors such as Foucault, Žižek, Lefebvre and Harvey, and their key ideas of governamentality, multicultural tolerance, and the right to the city. To conclude, I point out the contradictions of the dominant neo-liberal system, simultaneously forming exclusion and hope.
\end{abstract}

Keywords: access to housing; governamentality; multicultural tolerance; right to the city

Este artigo surge no âmbito de um estudo individual mais extensivo onde viso identificar estratégias, políticas, práticas espaciais e espaços habitacionais inclusivos para refugiados e migrantes vulneráveis em Portugal na actualidade, em contexto neoliberal ${ }^{1}$. Como referência e controlo recorro, nessa pesquisa, ao mote da produção do espaço habitacional para migrantes vulneráveis vindos de países africanos de língua portuguesa, desde há cerca de 40 anos, e seus descendentes. É nos pontos de contacto esboçados entre a produção oficial, leia-se condutas públicas, e práticas quotidianas, que viso encontrar respostas mais favoráveis à melhoria da qualidade de vida urbana destas populações. Esta dinâmica é complexa e contempla as permeabilidades dos actores e a integração de novos hábitos e costumes, numa lógica de reciprocidade.

O foco desta reflexão é o acesso ao espaço e à habitação em geral. O intuito é perceber como ensaios abrangentes conduzidos pela Nova Geração 
de Políticas de Habitação, lançada em 2017, podem contribuir positivamente para a inclusão socioespacial e habitacional de refugiados e migrantes vulneráveis. Aqui coloco as seguintes questões: (1) Qual a margem de manobra da actual governação nacional para contrariar as linhas sistémicas excludentes da conjuntura neoliberal dominante? (2) Qual a capacidade, no curto período legislativo, de criar mecanismos de inclusão habitacional para os grupos sociais de médios e de poucos recursos com repercussão positiva a médio e longo prazo? (3) De que forma a discriminação do "outro", migrante, condiciona o seu acesso à habitação e ao espaço habitacional, mesmo em cenários ditos apontados para a igualdade socioespacial?

Metodologicamente, recorro à sistematização das acções e contra-acções forjadas em torno da promoção do acesso à habitação e seus principais intervenientes, dando particular atenção ao receituário governamental recém-ratificado e em discussão, procurando apurar se esse acesso à habitação é defendido e promovido por todos. Também identifico os exemplos de exclusão dominantes, especialmente na Área Metropolitana de Lisboa (AML), onde reside $27,5 \%$ da população de Portugal ${ }^{2}$. E destaco as contradições que o governo actual enfrenta nos alegados processos de inclusão socioespacial, procurando verificar se a defesa e a promoção do acesso à habitação em Portugal são dirigidas a todos. A reflexão estrutura-se no cruzamento deste duplo esclarecimento com o conceito norteador de direito à cidade, na acepção crítica de Lefebvre (2009). Outras noções teóricas como governamentalidade e tolerância multicultural, advogadas por Foucault (2008) e Žižek (1997), também são abordadas fixando a tónica no controlo e na exclusão.

\section{Acesso à habitação}

O corrente contexto governativo português ${ }^{3}$, favorável à produção de uma Nova Geração de Políticas de Habitação (SEH, 2017), sucede ao Verão charneira de 2015 que assinalou a chegada massiva de refugiados oriundos de África e do Médio Oriente à Europa. Por sua vez, 2018 configurou a meta proclamada pelo Estado português para o seu maior acolhimento, 10000 pessoas, no quadro da recente crise político-económica e migratória europeia ${ }^{4}$. Contudo, hoje, em Portugal, outros desafios relacionados com a inclusão se perfilam com mais expressão, sendo o acesso à habitação por grupos de médios e parcos recursos uma preocupação do executivo. Ao mesmo tempo, a sociedade civil tem apontado situações de discriminação e de xenofobia no exercício de vários direitos, como à habitação, relacionadas com questões como a origem, etnicidade e cor da pele ${ }^{5}$.

Relativamente ao acesso à habitação através do mercado, em 2017 o Instituto Nacional de Estatística destacou o preço médio de compra em Lisboa, 2231 $€ / \mathrm{m}^{2}$, por ser o mais alto de Portugal (INE, 2017a) ${ }^{6}$. Outra fonte (CI/SIR apud. Lisboa custa, em média, 3291 euros por metro quadrado, 2017) menciona valores mais expressivos, $3291 € / \mathrm{m}^{2}$, atirando freguesias centrais (Santo António, Misericórdia, Parque das Nações) para $5456 € / \mathrm{m}^{2}$. Nestes locais mais procurados, o Jornal de Negócios (Ledo, 2018) divulgou vendas na ordem dos $10000 € / \mathrm{m}^{2}$, próximo dos valores de capitais com economias fortes, como Paris. Sabendo que, nesse ano, em Portugal, cada família apresentou um rendimento médio/ano de $€ 31$ 390,50 (Pordata, s.d.b), com poupança bruta correspondente a 5,4\% dessa receita (Pordata, s.d.c), a maioria não consegue comprar casa sem pedir um empréstimo bancário, ficando assim sujeita às oscilações económicas e seus impactes na taxa de juro e na prestação mensal. Sublinho que a poupança média anual destas famílias é significativamente menor do que o menor preço médio por metro quadrado ultimamente praticado na venda de casa em Lisboa (Quadros 1 e 2).

Quadro $1 \triangleright$ Valor de compra das habitações em Lisboa

\begin{tabular}{c|c|l|c}
\cline { 2 - 4 } & \multicolumn{2}{c|}{ Valor médio } & Valor excepcional \\
\hline Cidade & $2231 € / \mathrm{m}^{2 *}$ & $3291 € / \mathrm{m}^{2 * *}$ & - \\
\hline Centro & - & $5456 € / \mathrm{m}^{2}$ & $10000 € / \mathrm{m}^{2 * * *}$ \\
\hline
\end{tabular}

Fontes: *INE (2017a); **CI/SIR apud. Lisboa custa, em média, 3291 euros por metro quadrado, 2017; ***Ledo, 2018

Quadro $2 \triangleright$ Relação entre rendimento médio anual das famílias e poupança bruta

\begin{tabular}{c|c}
\hline Rendimento médio/ano & Poupança bruta/ano \\
\hline $100 \%$ & $5,4 \%$ \\
\hline$€ 31390,5$ & $€ 1695$ \\
\hline
\end{tabular}

Fonte: Pordata (s.d.a; s.d.b)

No que se refere às actuais situações de precariedade habitacional, após a auscultação dos municípios, o IHRU (2018, pp. 20-21) identificou 25762 famílias a necessitar de realojamento, encontrando-se a maioria nos distritos de Lisboa $(38,31 \%)$, Porto $(19,73 \%)$ e Setúbal $(16,15 \%)$. Mais de metade vive na AML $(54,46 \%)$ (Quadro 3). Juntando a Área Metropolitana do Porto (AMP), verificamos que quase três quartos das carências habitacionais em Portugal estão nas grandes cidades, corroborando a noção de que o magnetismo da urbanização prevalece em condições adversas. Sabemos, também, que nos distritos de Lisboa e Setúbal residem 209293 estrangeiros, 52,6\% dos 397731 cidadãos não portugueses com domicílio em Portugal (SEF, 2016, pp. 10-12) (Quadro 4). Os dados não contemplam os indivíduos que, entretanto, 
obtiveram nacionalidade portuguesa, sobretudo os africanos e seus descendentes, incluindo os de parcos recursos ${ }^{7}$. Porém, o levantamento habitacional do IHRU não relaciona os níveis de precariedade existentes com os contextos de origem, socioculturais e/ou étnicos dos sujeitos, e situações de discriminação ${ }^{8}$. Entretanto, estas existem e reproduzem-se no espaço habitacional que as denuncia, assumindo contornos próprios dentro do actual contexto dos paradigmas de exclusão socioespacial em Portugal. fundarei estas noções no ponto da reflexão cruzada sobre teorização dos factos.

\section{Paradigmas}

São três os exemplos de exclusão socioespacial e habitacional, de matriz neoliberal, que se destacam presentemente em Portugal, sobretudo na AML: (1) as práticas de renovação e reabilitação do centro urbano; (2) alguns realojamentos efectuados no

Quadro $3 \triangleright$ Necessidades de realojamento nas AML e AMP

\begin{tabular}{c|c|c|c|c}
\cline { 2 - 5 } & \multicolumn{2}{|c|}{ AML } & AMP & Total \\
\cline { 2 - 5 } & Lisboa & Setúbal & Porto & $100 \%$ \\
\hline \multirow{2}{*}{ Valores percentuais } & $38,31 \%$ & $16,15 \%$ & $19,73 \%$ & \\
\cline { 2 - 5 } & \multicolumn{2}{|c|}{$54,46 \%$} & 5222 & 25762 \\
\hline Valores absolutos & 9869 & 4161 & & \\
\hline
\end{tabular}

Fonte: IHRU (2018, pp. 20-21)

Quadro $4 \triangleright$ Cidadãos estrangeiros com domicílio na AML e Portugal

\begin{tabular}{|c|c|c|c|}
\hline & \multicolumn{2}{|c|}{ AML } & \multirow[t]{2}{*}{ Total } \\
\hline & Lisboa & Setúbal & \\
\hline \multirow{2}{*}{ Valores percentuais } & $43,53 \%$ & $9,10 \%$ & $100 \%$ \\
\hline & \multicolumn{2}{|c|}{$52,6 \%$} & \\
\hline \multirow{2}{*}{ Valores absolutos } & 173118 & 36175 & 397731 \\
\hline & \multicolumn{2}{|c|}{209293} & \\
\hline
\end{tabular}

Fonte: SEF (2016, pp. 10-12)

Lanço agora dois conceitos teóricos que se relacionam com o acesso à habitação em Portugal, ligados a questões de poder, neste caso económico, e a dinâmicas de racismo e xenofobia. Em 1977/78, Foucault (2008) discursou sobre a governamentalidade e a criação de mecanismos de alegada inclusão que, paradoxalmente, sustentam uma estrutura, per se, excludente; cerca de 20 anos depois, Žižek (1997) alertou sobre os perigos da tolerância multicultural que reforçam a discriminação pejorativa. Por sistema, a pobreza económica e a distinção negativa geram e potenciam situações de precariedade socioespacial e habitacional, por um lado, e, por outro, condicionam e/ou reduzem a margem de manobra dos vários actores que procuram inverter a tendência em benefício das comunidades afectadas. Sobre este tópico, Lefebvre $(2009 ; 2000)$ versou sobre a (re)produção do espaço desigual para a (re)produção de capital e, mais tarde reforçado por Harvey (2008), lançou como horizonte de esperança o conceito estruturante do direito à cidade. Apro- contexto do Programa Especial de Realojamento nas Áreas Metropolitanas de Lisboa e do Porto (PER, de 1993) ${ }^{9}$; e (3) o despejo forçado de habitantes de parcos recursos a viver precariamente em terrenos alheios. O cruzamento destes três paradigmas, suas especificidades e efeitos nefastos tem estimulado mobilizações sociais de reivindicação de direitos, de luta e contra-intervenção crítica, tendencialmente apontada para a construção colectiva de uma sociedade e uma cidade mais inclusiva.

A renovação e reabilitação do centro de Lisboa, em curso, está associada a dinâmicas de gentrificação, turistificação ${ }^{10}$ e captação de capital estrangeiro $^{11}$. O paradigma tem provocado o aumento do valor das rendas e de venda de habitação. Sobre o arrendamento, a lei de $2012^{12}$ potenciou, por um lado, esse acréscimo e a atualização dos contratos e, por outro lado, a sua rescisão, dando origem a ordens de despejo. No primeiro caso, muitos arrendatários não têm capacidade de pagar as rendas actualizadas. O segundo caso é motivado pelas lucra- 
tivas oportunidades de venda e/ou transformação dos imóveis em alojamentos locais ${ }^{13}$, com preços diários elevados e com baixa tributação fiscal. São exemplos mediatizados os edifícios da seguradora Fidelidade, em Santo António de Cavaleiros (Loures), adquirida pelo grupo de investimento chinês Fosun, onde 150 famílias foram despejadas para venda dos imóveis; e do prédio na Rua dos Lagares (Mouraria, Lisboa), onde 16 famílias enfrentaram ordens de despejo após venda do edifício para transformação em alojamento local. Aqui, o município conseguiu negociar com o investidor a permanência de todos os visados. Ao mesmo tempo, a retoma progressiva de empréstimos bancários em dita pós-crise financeira, com prestações mensais inferiores às praticadas em arrendamento ${ }^{14}$, tem incentivado as compras ${ }^{15}$. No entanto, muitos não têm capacidade de as realizar ${ }^{16}$. Estas dinâmicas têm empurrado a classe média para periferias ou núcleos urbanos confinantes onde os preços geralmente são mais baixos. Consequentemente, as comunidades empobrecidas que aí residem, como as famílias de origem africana, entre outras, tendem a ser expulsas para margens mais distantes, potencialmente mais acessíveis.

O PER, presentemente em fecho, apoiou financeiramente os municípios para erradicarem as muitas barracas existentes em Portugal no final do século passado, especificamente nas Áreas Metropolitanas de Lisboa e do Porto, e para realojarem os seus moradores em habitações de custo controlado. Identificam-se, aqui, dois problemas de imediato: o programa não abrangeu os agregados que se fixaram nos bairros depois do recenseamento de 1993 (com suas actualizações); novas formas de exclusão socioespacial emergiram e agravaram desde a sua publicação. Além disso, apesar da sua alta taxa de execução, 94\%, 2884 famílias permaneceram por realojar (Lusa, 2017, Abril 15) ${ }^{17}$. Destas, 2117 residem na AML. Mais, dado o grande desfasamento temporal, 25 anos, consolidaram-se novas situações de precariedade habitacional, assinaladas no levantamento do IHRU. Neste contexto, o programa PROHABITA de 2004 configurou um remate de pequena escala, abrangendo situações de grave carência habitacional em todo o território nacional. O programa apostou antes na comparticipação das rendas e no financiamento da compra de casa através de empréstimos bonificados, transferindo para o mercado livre grandes benefícios e responsabilidades socioespaciais. Como ocorreu com o PER nos últimos anos, também o PROHABITA teve pouca cobertura orçamental.

Outra face da exclusão habitacional relaciona-se com a demolição das casas e a expulsão dos grupos de poucos recursos, muitos de origem africana ou etnia cigana, a habitar em terrenos de outrem, públicos ou privados, não listados para realojamento e sem criação de alternativas condignas. Na AML, os bairros de Santa Filomena (extinto em 2016) e 6 de Maio (em fim de extinção), situados em locais estratégicos da Amadora, integram o processo municipal de erradicação de bairros degradados no quadro do PER, sendo exemplares pela grandeza da destruição e pelos despejos forçados de que recentemente foram e/ou são alvo (Figura 1). No primeiro caso, os terrenos são sobretudo do Villafundo - Fundo Especial de Investimento Imobiliário Fechado. No segundo caso, existe um projecto de urbanização e de edificação preanunciado para os terrenos municipais e privados que ali estavam ocupados. Neste quadro, o papel de grupos críticos como a associação Habita e a plataforma Stop Despejos ${ }^{18}$ tem sido fundamental na denúncia destes e/ou de outros casos relacionados, especialmente junto da comunicação social e da opinião pública. Estas mobilizações reforçam a voz das populações visadas, por vezes logrando abrandar os processos, mas geralmente sem os conseguir travar. Contudo, as suas acções são resistentes e alimentam o debate público em torno das responsabilidades do governo no que se refere à produção de espaços habitacionais infra-estruturados (com acesso à água, electricidade, saneamento, espaços públicos, etc.) e à promoção de formas de inclusão socioespacial para comunidades despejadas, considerando a propriedade.

Figura $1 \triangleright$ Demolições no bairro 6 de Maio (Amadora)

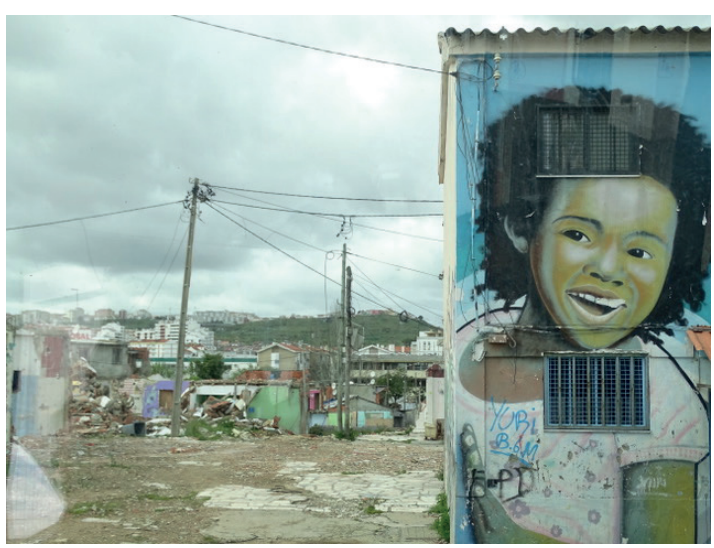

Fonte: Autora (2018)

\section{Paradoxos}

São vários os paradoxos de inclusão-exclusão socioespacial e habitacional, de forte pendor neoliberal, que o governo português tem presentemente de enfrentar. Para perceber os seus significados, tenho necessariamente de situar a Nova Geração de Políticas de Habitação ${ }^{19}$ e o Projecto de Lei de Bases da Habitação ${ }^{20}$, e identificar os actores-chave e as principais forças envolvidas na arena ideológico- política em torno do acesso à habitação, e suas linhas de intervenção. Os processos relacionados 
são intrincados e compreendem conflitos (1) dentro da esfera governamental, (2) entre o governo e as lutas sociais ligadas ao espaço, (3) dentro das mobilizações, e (4) entre grupos críticos, sendo a cooptação dos intervenientes pelo sistema dominante uma divergência fracturante.

A criação de uma Nova Geração de Políticas de Habitação (SEH, 2017) sugere uma estreita articulação de interesses nos ministérios que tutelaram ou actualmente tutelam a Secretaria de Estado da Habitação, produtora do pacote programático: o Ministério do Ambiente e Transição Energética, responsável pela coesão socioterritorial de Portugal, em 2017/2018; o Ministério das Infraestruturas e da Habitação, em 2019. Após consulta pública realizada em 2017, foram aprovados vários instrumentos apontados para o acesso de todos a uma habitação condigna ${ }^{21}$, sobretudo através da criação de incentivos para a reabilitação e o arrendamento a preços ditos acessíveis. Todavia, o valor disponibilizado no Orçamento do Estado de 2018 para a sua implementação foi deveras insuficiente ${ }^{22}$. Acresce que os instrumentos são contraditórios e muito dificilmente lograrão contrariar plenamente os paradigmas de exclusão identificados. Sobre o arrendamento, a desregulação do mercado e a escassez de casas têm proporcionado, por um lado, o aumento excessivo da caução e, por outro lado, a escolha dos arrendatários de acordo com a sua nacionalidade, cor da pele ou duração do contrato, entre outros indicadores discriminatórios. No tocante aos realojamentos, além das 2884 famílias que permanecem por instalar via PER, os municípios identificaram 25762 agregados a precisar de apoio estatal. Os programas anteriores não travaram esta tendência. Agora as novas políticas públicas apostam na descentralização, implicando, no que se refere à população carenciada, a elaboração de Planos Municipais de Estratégia Local de Habitação que identifiquem diversas necessidades. Como ocorreu no levantamento do IHRU, este reconhecimento dependerá dos recursos existentes (humanos, financeiros, etc.), muitas vezes escassos, e de vontades e/ou orientações políticas diferentes, como por exemplo as da Amadora, que tem promovido despejos forçados sem alternativas.

O Projecto de Lei de Bases da Habitação, recém-traçado pelo Grupo Parlamentar do Partido Socialista $(2018)^{23}$, foi submetido a consulta pública e propõe genericamente (1) a requisição temporária de habitações devolutas, (2) a fixação de rendas e (3) a atribuição de subsídios de arrendamento. Este quadro jurídico advoga a construção de estratégias municipais de habitação que definam limites para actividades conflituantes com o acesso à habitação permanente e afirma o papel das juntas de freguesia no reconhecimento de carências graves e recursos existentes. Isto cruza-se com o tema das casas vazias, expectantes de negócio e lucro, menos vívido ao nível do pequeno proprietário, porém com grandes implicações à escala dos fundos imobiliários internacionais. Quanto aos edifícios devolutos do Estado, foi criado um Fundo Nacional de Reabilitação do Edificado ${ }^{24}$, apontado para a habitação com rendas acessíveis. Contudo, os diplomas relacionados com arrendamento e tributação imobiliária não foram a votação no hemiciclo por falta de consenso partidário, logo não foram aprovados a tempo de caber no Orçamento do Estado de 201925. Em contratempo, agudizam-se as forças contrárias do sistema dominante, reforçando os seus paradoxos. Recordo, por exemplo, o leilão de casas efectuado ao abrigo do Programa Renda Acessível, promovido pela Câmara Municipal de Lisboa e a empresa municipal Sociedade de Reabilitação Urbana (Lisboa Ocidental), onde um apartamento de tipologia T1 foi atribuído por $€ 760$, um valor muito acima do limite estipulado para as maiores tipologias ( $€ 450)$ (Lança, 2018). O procedimento foi criticado e, entretanto, anulado.

Em Portugal, sobretudo na AML, as resistências e lutas pelo direito ao lugar e habitação são crescentes. Por um lado, os grupos de parcos recursos, muitas vezes representados por minorias culturais e étnicas, tendem a ser despejados. E, quando são realojados, em alguns casos são confrontados com novas formas de exclusão, por exemplo o seu afastamento para as margens urbanas. Por outro lado, muita classe média não consegue renovar os seus contratos, vendo-se inibida do acesso à habitação, sobretudo no centro urbano. Neste contexto, sendo produto da mobilização social de vários actores, com reverberação mediática e na esfera parlamentar transpartidária (Figura 2), foram ultimamente aprovados dois instrumentos políticos relevantes: o regime extraordinário para o abastecimento provisório de energia eléctrica às habitações precárias que abrangem famílias em situação económica e social vulnerável ${ }^{26}$, por exemplo no bairro da Torre (Camarate, Loures), não concretizado à data; e uma suspensão provisória dos despejos dos arrendatários idosos ou deficientes a viver numa casa há mais de 15 anos $^{27}$, entretanto tornada definitiva. Estes diplomas foram alvo de relutância por parte, respectivamente, da EDP e de uma miríade de proprietários. Em termos úteis, são as comunidades lesadas que motivam as mobilizações que sustentam resoluções políticas que, respondendo a urgências, revertem em seu benefício. Em paralelo ou, pontualmente, em conjunto, induzem ou operacionalizam resistências que, em última análise, se traduzem em ganhos desequilibrados conforme os estratos socioeconómicos envolvidos. Aqui o grande paradoxo reside no facto de os proveitos da classe média não contribuírem, necessariamente, para o aumento equitativo dos recursos dos grupos carenciados, sequer proporcional, mantendo-se e 
reproduzindo-se o fosso socioeconómico, espacial e habitacional, etc., intrínseco ao sistema hegemónico capitalista e neoliberal.

Figura $2 \triangleright$ Visita do Grupo [parlamentar multipartidário] de Trabalho da Habitação, Reabilitação Urbana e Políticas de Cidade ao bairro da Torre (Camarate), 18/07/2017

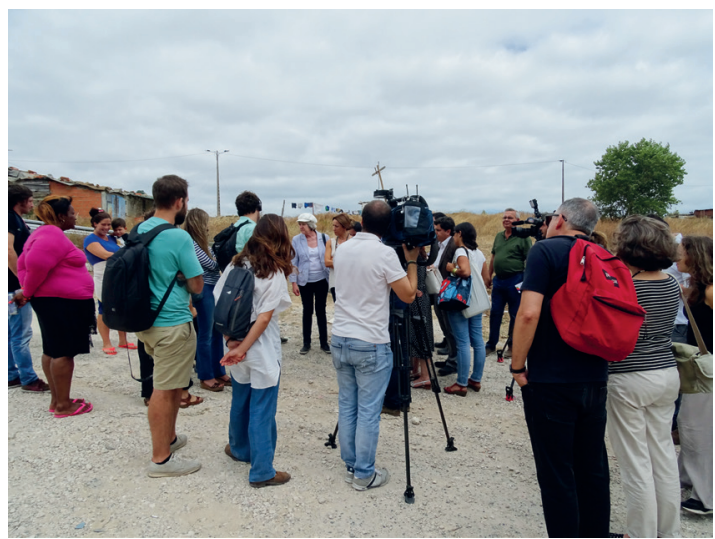

Fonte: Autora (2017).

\section{Teorizando factos}

Esta teorização sobre paradigmas de exclusão baseia-se na reflexão de Foucault (2008) sobre a governamentalidade, ou seja, a forma como o governo procura incluir os seus cidadãos, envolvendo-os em acções apontadas para a manutenção e reprodução das suas próprias lógicas (neste caso de mercado), normalizando-os para que estes cumpram melhor as suas políticas. Também se baseia no ideário ficcionado de tolerância multicultural, como identificado por Žižek (1997), uma abordagem etnocêntrica e condescendente muito favorável à emergência do fundamentalismo e da xenofobia. Contudo, é no pensamento estruturante de Lefebvre (2000) que sustento a minha reflexão sobre produção do espaço político, de modo geral excludente, movida pelo forte valor de troca, simultaneamente espaço físico e prática espacial. E que descodifico o significado do acesso a múltiplos direitos (como à habitação, infra-estruturas, benefícios urbanos, etc.), sendo que a sua soma não resulta na construção duma plena cidadania, sequer no sistema participado e de apropriação colectiva (do espaço e poder) inerente à ideia-chave de direito à cidade, aqui bem sintetizado por Harvey (2008, p. 23): constitui-se como "um direito coletivo e não um direito individual, já que mudar a cidade depende, inevitavelmente, do exercício de um poder coletivo sobre os processos de urbanização"28.

Os paradigmas de exclusão socioespacial e habitacional apresentados apontam para uma diversidade de situações que condicionam ou (re) definem a sociedade urbana em Portugal, sobretudo na AML. Incluem os tópicos da habitação orientada para o mercado, de promoção pública e de constrangimento do acesso à habitação condigna. No primeiro caso, renovação e reabilitação do centro urbano, o mercado cria os mecanismos de que depois se alimenta para reproduzir o capital e o mesmo sistema excludente que o gera, reforçando a teoria de Foucault (2008). No caso do PER, a ideia de regularização e de controlo prevalece (ibid.), sendo que a inclusão de comunidades empobrecidas, de diferentes origens e etnias, (1) não se efectivou plenamente, (2) ocorreu num universo geográfico-temporal específico e (3) potenciou novas situações de exclusão, sincrónicas com outras tantas, reproduzindo dinâmicas de tolerância multicultural (Žižek, 1997). Já através do PROHABITA, o Estado passou para as dinâmicas de mercado o ónus da exclusão, espelhada nos espaços desiguais, mais ou menos centrais ou periféricos, e mais ou menos urbanizados ou precários, conforme a economia dos habitantes (Lefebvre, 2000). Na terceira situação, com a expulsão de populações, sem direito ao lugar ou compensações, estas noções teóricas cruzam-se e reforçam-se, afastando-se mais do direito à cidade (Lefebvre, 2009; Harvey, 2008), orientando o meu olhar para lógicas paradoxais de inclusão-exclusão.

Teorizando agora sobre os paradoxos de inclusão-exclusão socioespacial e habitacional, evoco novamente Foucault (2008) e o conceito de governamentalidade. A ideia captura um processo contraditório - a inclusão como forma de exclusão (ou rumo para) -, implicando uma maior vigilância e controlo do Estado sobre o comportamento da sociedade. Também retomo a noção apontada de tolerância multicultural (Žižek, 1997, p. 44), sendo que esta, em contexto global neoliberal, remete para uma abordagem etnocêntrica e condescendente, assente numa forma respeitosa de "racismo com distância", para afirmação da sua própria superioridade. A descodificação deste processo deveras paradoxal - aceitação como forma de rejeição desvia o foco da Europa, antes centrado no choque entre culturas, para o conflito existente entre visões antagónicas sobre a coexistência de diferentes culturas (Žižek, 2016). Quanto a alternativas, Foucault (2008) apela à resistência e à contra-conduta da sociedade, tendo em conta o seu autoconhecimento para protecção das suas necessidades colectivas, enquanto Žižek (2016) advoga o compromisso da solidariedade global. Nessa senda, Harvey (2000) propõe o uso útil das inconsistências do sistema, visando a construção de uma sociedade emancipada e mais justa. Referente a intervenções e à sua materialidade, Lefebvre (2000) introduz a noção de produção social do espaço social, de representação, tendencialmente mais inclusivo, tendo em conta o seu valor de uso. 
O reconhecimento de alguns paradoxos de inclusão-exclusão socioespacial e habitacional em Portugal remete para as contradições e/ou conflitos latentes ou expressivos entre os vários intervenientes na defesa do acesso à casa, por todos e para todos, e seus efeitos. Esta agnição abrange questões derivadas de estratégias, políticas e instrumentos programáticos e legais, promovidos pelo governo, no entanto motivados por dinâmicas de resistência, posteriormente sujeitos a consulta pública. Nesta situação, os mecanismos produzidos ou em esboço estão orientados para o controlo estatal das comunidades e suas dinâmicas habitacionais, e para a regulação dentro do sistema económico vigente, robustecendo as dinâmicas de governamentalidade sinalizadas por Foucault (2008). Também seguem a senda da tolerância multicultural (Žižek, 1997), quando assumem a inclusão de classes mais vulneráveis e desfavorecidas, e seus diversos constituintes, através do reconhecimento da coexistência da diferença. Além do mais, as recentes respostas públicas às resistências advogam a defesa da sociedade e das suas necessidades colectivas, sendo esta uma dinâmica instigada por Foucault (2008). Porém, essas contra-condutas só ocorrem quando perfilhadas por mobilizações sociais engajadas em torno de uma solidariedade global (Žižek, 2016). Relativamente aos processos habitacionais, a questão central reside no conflito inerente à defesa do valor de uso, próprio da produção do espaço social, na linha de Lefebvre (2000), pela mesma governação que reproduz o sistema neoliberal e, consequentemente, as suas lógicas de exclusão. Paradoxalmente, assumindo a leitura de Harvey (2000), são estas inconsistências que, per se, potenciam a emancipação de uma sociedade mais justa.

\section{Tendências}

Estas notas reflexivas resultam do cruzamento empírico-teórico em torno dos paradigmas e paradoxos de inclusão-exclusão socioespacial e habitacional em Portugal e procuram contribuir para apurar se, neste quadro, todos defendem e/ /ou promovem o acesso à casa, e se todos os beneficiários são contemplados pelas novas dinâmicas ditas inclusivas. O propósito é situar processos complexos e muito expressivos como os da AML e enquadrar o actual contexto económico, político e socioespacial encontrado pelas novas vagas de migrantes vulneráveis e refugiados. Os paradigmas mais recorrentes são a renovação e a reabilitação do centro, alguns realojamentos e despejos forçados. Os paradoxos contemporâneos decorrem de políticas governamentais e de práticas de resistência e luta em função do público-alvo. Os níveis identificados estratégias, políticas, instrumentos e práticas - são descodificados através da lente conceptual provida pelos autores teóricos seleccionados, após enqua- drados no que se refere a leituras discriminatórias do "outro", tendo em conta factores económicos e sociais. Ao mesmo tempo, procuro responder às questões introdutórias relacionadas com o sistema neoliberal e governativo.

Qual a margem de manobra da actual governação nacional para contrariar as linhas sistémicas excludentes da conjuntura neoliberal dominante? 0 sistema capitalista alimenta-se das crises globais que o constituem, reforçando-o, originando carências financeiras e de acesso aos mais variados direitos, como à habitação. Na AML, a discrepância entre rendimento das famílias e os preços de aquisição de casa é um exemplo expressivo desta situação. 0 aumento do valor das rendas configura outra face da questão, originando despejos. Estas dinâmicas cruzam-se com processos de realojamento e passagens de responsabilidades para os mercados, estando na origem de situações de periferização e exclusão socioespacial, principalmente das comunidades mais carenciadas. A situação agrava-se quando a produção da habitação e espaço habitacional, na acepção de Lefebvre (2000), colide com o direito à propriedade privada. Porém, recentemente, emergiu no quadro governativo português uma força política que afirma estar empenhada na promoção do acesso à habitação adequada para todos. Foram aprovados múltiplos instrumentos, estando em discussão parlamentar outros ligados, sobretudo, à reabilitação urbana e ao arrendamento acessível. Todavia, seguindo Foucault (2008), os mecanismos de inclusão recém-criados são paradoxais e não contrariam plenamente a conjuntura dominante na origem dos processos excludentes em curso. Acresce que a margem de manobra da governação fica condicionada pela fraca afectação de recursos para a sua implementação, sendo esta recusa apoiada pelas forças ideológicas, económicas, estratégicas e políticas contrárias.

Qual a capacidade, no curto período legislativo, de criar mecanismos de inclusão habitacional para os grupos sociais de médios e de poucos recursos com repercussão positiva a médio e longo prazo? Ainda que as forças se alinhem no sentido de viabilizar as medidas ratificadas ou em esboço, a proposta estatal do acesso à habitação para todos reforça o sistema existente e suas contradições, ainda na senda de Foucault (2008). Recordo o transvio neoliberal do leilão do Programa Renda Acessível, da Câmara Municipal de Lisboa, uma ofensiva que pode ser reinventada na municipalização das políticas de habitação. Mesmo assim, no actual período governativo - 4 anos -, a discussão e produção de vários programas e diplomas no quadro específico da Nova Geração de Políticas de Habitação suporta a narrativa pública de "boas intenções e regras" apontadas para o acesso à habitação. Neste âmbito, o governo promove a auscultação pública como abordagem metodológica. Trata-se de um processo 
que afirma na produção do espaço político, tendencialmente excludente, porque com elevado valor de troca (Lefebvre, 2000), o carimbo do exercício de um (muito pequeno e sectário) poder colectivo construído na, e pela, luta pelo direito ao lugar e à habitação. No entanto, o quadro é bastante burocratizado e não responde de forma satisfatória às lutas habitacionais da sociedade civil resistente e das comunidades que representa. A dinâmica não reverte expressivamente para a igualdade de oportunidades e recursos das comunidades e não concorre para a construção do direito à cidade, sabendo as limitações que impõe à participação e apropriação do espaço, defendidas por Lefebvre (2009) e Harvey (2008). Mas reconhece a importância do acesso a múltiplos direitos (à habitação, infra-estruturas, benefícios urbanos) sem, contudo, os garantir, configurando mais um paradoxo de inclusão-exclusão socioespacial e habitacional e, também, da fabricação da própria cidadania.

De que forma a discriminação do "outro", migrante, condiciona o seu acesso à habitação e ao espaço habitacional, mesmo em cenários ditos apontados para a igualdade socioespacial? A captação de capital estrangeiro encontra-se associada ao paradigma da renovação e reabilitação dos centros urbanos, como o de Lisboa. Envolve processos de gentrificação e periferização que, contraditoriamente, penalizam a classe média e as classes mais carenciadas. Em simultâneo, em situação de despejo, em realojamento e expulsão forçada, as comunidades carenciadas, multiculturais e multi-étnicas, tendem a ser precarizadas. A mobilização social dos actores envolvidos na resistência e na luta pelo direito à habitação e ao habitar condigno influenciou regimes extraordinários como o abastecimento provisório de energia eléctrica em habitações precárias de comunidades empobrecidas a viver em terrenos alheios nas periferias das cidades, ainda não efectivado. Nada que se assemelhe à possibilidade de habitar em casa própria e/ou arrendada no centro, junto dos benefícios da urbanização sublinhados por Lefebvre (2009). A diferenciação paradoxal da aceitação do "outro" como exercício de rejeição, na linha de Žižek (1997), ganha assim forma, materializando-se a coexistência etnocêntrica e condescendente entre diferentes estratos socioeconómicos e culturais. Acresce que é, também, pela coabitação de dois actores em representação de forças polarizadas, investidor estrangeiro versus migrante empobrecido, que ocorrem os processos que estão na origem do que Žižek (1997) define como distância de superioridade.

\section{Conclusão}

Em Portugal, nem todos defendem o acesso à habitação e ao espaço habitacional para todos, nem sequer o promovem. Pelo contrário, são múltiplas as forças dominantes que se opõem a esta dinâmica resistente. Simultaneamente, os benefícios alcançados ou na forja estão estratificados de acordo com diferentes níveis socioeconómicos e culturais, proporcionando níveis distintos de inclusão. Estes processos, reprodutores de desigualdades, são visíveis sobretudo na $A M L$, e tendem a excluir situações de choque entre o direito ao lugar e à propriedade. Aqui, em situação de despejo, paradoxalmente, as lutas comuns são mais fortes, todavia com menos resultados. Isto ocorre porque a posse sustenta a mercantilização da propriedade, permitindo a reprodução do capital. Razão também pela qual, no actual quadro neoliberal, os interesses financeiros dos senhorios tendem a ser privilegiados. No entanto, os ensaios conduzidos pela Nova Geração de Políticas de Habitação podem reverter positivamente para a inclusão habitacional dos refugiados e migrantes vulneráveis em Portugal, tendo em conta que configuram uma reforma pública que - alegadamente - visa responder (1) a uma luta socioespacial conjunta, (2) a dinâmicas de consulta pública, e (3) a questões de segregação e periferização nos grande núcleos urbanos, tendo como amplo foco a construção da cidadania. Quanto à miríade de paradoxos identificados, verifico que estes, tal como as crises sistémicas, configuram uma faceta estruturante do sistema neoliberal em curso que, mesmo questionando-o, também o fortalece. Neste quadro, os ecos positivos de esperança das novas políticas do governo são, per se, paradoxais, sugerindo que o tal horizonte de esperança que constitui o Direito à Cidade se encontra fora do modo de produção capitalista e sobretudo aí se poderá forjar.

\section{Notas}

1 Pós-doutoramento em curso no CES-UC com financiamento da FCT (2017/2023) - INSEhRE21. Inclusão sócio-espacial e habitacional dos refugiados na Europa de hoje: Lições da diáspora africana em Portugal.

2 2,821 milhões de um total de 10,256 milhões de pessoas (Área Metropolitana de Lisboa, s.d.; Pordata, s.d.a).

3 A coligação parlamentar de esquerda apoiante do governo socialista em funções desde 2015.

4 Portugal recebeu 1674 refugiados entre finais de 2015 e início de 2018 (PAR, 2018)

5 O trabalho jornalístico de Henriques (2018a) tem mediatizado o assunto.

6 A média nacional é $896 € / \mathrm{m}^{2}$ (INE, 2017a).

7 A versão mais recente da Lei da Nacionalidade alargou o acesso à nacionalidade originária e à naturalização às pessoas nascidas em território português: Lei Orgânica n. ${ }^{\circ} 2 / 2018$, de 5 de Julho. DR 128/2018, Série I. Lisboa: Assembleia da República.

8 Como nos censos, onde não há consenso sobre o assunto (Público, 2018b). 
9 Decreto-Lei n.o 163/1993, de 7 de Maio. DR 106/1993, Série $I-A$. Lisboa: Ministério das Obras Públicas, Transportes e Comunicações.

10 Barata-Salgueiro, Mendes e Guimarães (2017) tratam o assunto.

11 Por exemplo, atribuindo vistos Gold a não-membros da União Europeia em caso de investimento superior a $€ 500000$.

12 Lei n. ${ }^{0}$ 31/2012, de 14 de Agosto. DR 157/2012, Série I. Lisboa: Assembleia da República. Promovida pela coligação governamental de centro-direita PSD/CDS-PP (2011-2015).

13 Aprovado pelo Decreto-Lei n. ${ }^{\circ}$ 128/2014, de 29 de Agosto. DR 166/2014, Série I. Lisboa: Ministério da Economia. Recentemente foi criado um regime de suspensão de novos registos em áreas centrais da capital (JN, 2018).

14 Alugar um apartamento de $100 \mathrm{~m}^{2}$ em Lisboa custa sensivelmente $1000 € /$ mês. Comprar o mesmo imóvel custa cerca de $€ 223100$ (INE, 2017b). A prestação mensal correspondente é de €665, segundo simulação no portal Idealista (Idealista: simulador do crédito à habitação, s.d.) para um empréstimo bancário de $80 \%$ do valor total, com pagamento a 30 anos e uma taxa de juro de $2 \%$.

15 A AML teve o maior crescimento do valor de venda (26,4\%) no segundo trimestre de 2017 (INE, 2017c).

16 A plataforma de simulação de crédito à habitação Compara.Já afirma que sensivelmente $40 \%$ dos seus 6000 utilizadores não conseguiria pagar a prestação mensal (Lusa, 2017. Outubro 29).

17 Foram recenseadas 48416 famílias das quais mais de 33 mil residiam na AML (Lusa, 2017. Abril 15).

18 A plataforma Stop Despejos foi criada após a extinção do bairro Santa Filomena.

19 Promovida pela secretária de Estado da Habitação, Ana Pinho.

20 O Projecto de Lei n. ${ }^{\circ}$ 843/XIII é da autoria da deputada Helena Roseta.

21 Programas: $1 .^{\circ}$ Direito - Apoio ao Acesso à Habitação, Porta de Entrada, Arrendamento Acessível, Chave na Mão - Mobilidade Habitacional para a Coesão Territorial, Da Habitação ao Habitat; e, também, Taxas autónomas diferenciadas para os arrendamentos habitacionais com contratos de longa duração, e Alterações legislativas ao arrendamento urbano (Portal da Habitação, 2018).

22 O Orçamento do Estado de 2019 prevê $€ 156$ milhões em gastos com políticas de habitação e reabilitação e com a saúde, por exemplo, €10 922,9 milhões (Pinto, 2018a; Campos, 2018)

23 Os partidos que sustentam a maioria governativa junto com o Partido Socialista, Bloco de Esquerda e Partido Comunista Português, também desenvolveram propostas para a Lei de Bases da Habitação.

24 Resolução do Conselho de Ministros n.o 48/2016, de 1 de Setembro. DR 168/2016, Série I. Lisboa: Presidência do Conselho de Ministros.

25 Levando à saída de Helena Roseta do Grupo [parlamentar multipartidário] de Trabalho da Habitação, Reabilitação Urbana e Políticas de Cidade. A deputada entretanto propôs a criação de uma Autoridade Nacional para a Habitação (Pinto, 2018b)
${ }^{26}$ Decreto-Lei n. ${ }^{\circ}$ 36/2018, de 22 de Maio. DR 98/2018, Série I. Lisboa: Presidência do Conselho de Ministros.

27 Lei n. 0 30/2018, de 16 de julho. DR 135/2018, Série I. Lisboa: Assembleia da República.

28 Tradução livre do original, pela autora.

\section{Referências bibliográficas}

Área Metropolitana de Lisboa (s. d.). Disponível em https://www.aml.pt/index.php

Barata-Salgueiro, T., Mendes, L., \& Guimarães, L. (2017). Tourism and urban changes. Lessons from Lisbon. In M. Gravari-Barbas \& S. Guinand (Eds.), Tourism and gentrification in contemporary metropolises. International perspectives (pp. 255-275). Londres: Routledge.

Câmara de Lisboa aprova restrições ao alojamento local. Jornal de Notícias, 25 de outubro de 2018. Retirado de https://www.jn.pt/local/noticias/lisboa/lisboa/ interior/camara-de-lisboa-aprova-restricoes-ao-alojamento-local-10088501.html

Campos, A. (2018, Outubro 16). Saúde vai ter mais 523 milhões de euros em 2019. Público. Retirado de https://www.publico.pt/2018/10/16/sociedade/ noticia/ministerio-da-saude-vai-ter-mais-523-milhoes-de-euros-em-2019-1847680

Decreto-Lei n.o 128/2014 de 29 de Agosto. Diário da República 166/2014 - Série I. Lisboa: Ministério da Economia

Decreto-Lei n.o 163/1993 de 7 de Maio. Diário da República 106/1993 - Série I-A. Lisboa: Ministério das Obras Públicas, Transportes e Comunicações.

Decreto-Lei n.o 36/2018 de 22 de Maio. Diário da República 98/2018 - Série I. Lisboa: Presidência do Conselho de Ministros

Decreto-Lei n.o 36/2018 de 22 de Maio. Diário da República 98/2018 - Série I. Lisboa: Presidência do Conselho de Ministros

Foucault, M. (2008). Segurança, território e população. São Paulo: Martins Fontes.

Grupo Parlamentar do Partido Socialista (2018). Projeto de Lei n. 843/XIII, Lei de Bases da Habitação. Disponível em https://www.parlamento.pt/ActividadeParlamentar/Paginas/DetalheIniciativa. aspx?BID $=42502$

Harvey, D. (2000). Spaces of hope. Edimburgo: Edinburgh University Press.

Harvey, D. (2008). The right to the city. New Left Review, 53, 23-40. Disponível em http://newleftreview. org/II/53/david-harvey-the-right-to-the-city

Henriques, J. G. (2018a). Racismo à Portuguesa. Disponível em https://acervo.publico.pt/racismo-a-portuguesa

Henriques, J. G. (2018b, Fevereiro 5). Não há consenso para questionar origem étnico-racial no próximo Censos. Público. Retirado de https:// www.publico.pt/2018/02/05/sociedade/noticia/ pergunta-no-censos-sobre-origem-etnicoracial-nao-e-consensual-1802093

Idealista: simulador do crédito habitação (s. d.). Disponível em https://www.idealista.pt/credito-habitacao/simulador-credito 
IHRU (2018). Levantamento nacional das necessidades de realojamento habitacional. Disponível em https://www.portaldahabitacao.pt/opencms/ export/sites/portal/pt/portal/habitacao/levantamento_necessidades_habitacionais/Relatorio_Final_Necessidades_Realojamento.pdf

INE (2017a). Estatísticas de preços da habitação ao níve local. 2.0 Trimestre de 2017. Destaque, informação à comunicação social. Disponível em https:// www.ine.pt/xportal/xmain?xpid=INE\&xpgid=ine destaques\&DESTAQUESdest_boui $=282088726 \& \bar{D}$ ESTAQUESmodo $=2 \& \times$ lang $=\overline{p t}$

INE (2017b). Estatísticas de rendas da habitação ao nível local. Destaque, informação à comunicação social. 21 de Março. Disponível em https://www. ine. $p t / x p o r t a l / x m a i n ? \times p i d=I N E \& \times p g i d=i n e$ destaques\&DESTAQUESdest boui $=3147533148$ DESTAQUESmodo $=2 \& \times$ lang $=\mathrm{pt}$

INE (2017c). Índice de preços de habitação. 3. trimestre de 2017. Destaque, informação à comunicação social. Disponível em https://www. ine.pt/xportal/xmain?xpid=INE\&xpgid=ine destaques\&DESTAQUESdest_boui $=281445039 \&$ DESTAQUESmodo $=2 \& \times$ lang $=p t$

Lança, F. (2018, Abril 24). Câmara de Lisboa já suspendeu polémico leilão de casas com renda acessível. Jornal de Negócios. Retirado de https://www. jornaldenegocios.pt/economia/rendas/detalhe/ camara-de-lisboa-ja-suspendeu-polemico-leilao-de-casas-com-renda-acessivel

Ledo, W. (2018, Janeiro 31). Comprar casa no Chiado pode custar mais de 10000 euros por metro quadrado. Jornal de Negócios. Retirado de https:// www.jornaldenegocios.pt/empresas/imobiliario/ detalhe/comprar-casa-no-chiado-pode-custar-mais-de-10000-euros-por-metro-quadrado

Lefebvre, H. (2000). La production de I'espace. Paris: Anthropos.

Lefebvre, H. (2009). Le droit à la ville. Paris: Anthropos.

Lei n.o 30/2018 de 16 de julho. Diário da República 135/2018 - Série I. Lisboa: Assembleia da República

Lei n. $031 / 2012$ de 14 de Agosto. Diário da República 157/2012 - Série I. Lisboa: Assembleia da República

Lei Orgânica n. 0 2/2018 de 5 de Julho. Diário da República 128/2018 - Série I. Lisboa: Assembleia da República

Lisboa custa, em média, 3291 euros por metro quadrado. Jornal de Negócios, 23 de outubro de 2017 Retirado de https://www.jornaldenegocios.pt/ multimedia/infografias/detalhe/lisboa-custa-em-media-3291-euros-por-metro-quadrado

Lusa (2017. Abril 15). Programa Especial de Realojamento tem cerca de 2800 famílias à espera de casa. Público. Disponível em https://www.publico. pt/2017/04/15/sociedade/noticia/programa- -especial-de-realojamento-tem-cerca-de-2800-familias-a-espera-de-casa-1768866

Lusa (2017. Outubro 29). Simulação de crédito habitação indica que $40 \%$ dos portugueses teria dificuldades em pagar. Diário de Notícias. Retirado de https:// www.dn.pt/lusa/interior/simulacao-de-credito-habitacao-indica-que-40-dos-portugueses-teria-dificuldades-em-pagar-8880729.html

Pinto, L. (2018a, Outubro 16). Governo destina 156 milhões a Políticas de Habitação e Reabilitação. Público. Retirado de https://www.publico. pt/2018/10/16/economia/noticia/orcamento-de-estado-destina-156-milhoes-de-euros-a-politicas-de-habitacao-e-reabilitacao-1847718

Pinto, L. (2018b, Novembro 13). Helena Roseta propõe uma Autoridade Nacional para a Habitação. Público. Retirado de https://www.publico.pt/2018/11/13/ economia/noticia/helena-roseta-vai-propor-criacao-autoridade-nacional-habitacao-1850801\#gs. Dvr3Qifi

Plataforma de apoio aos refugiados (2018). Disponível em http://www.refugiados.pt/refugiadosemportugal/

Pordata (s.d.a). BI de Portugal. Disponível em https:// www.pordata.pt/Portugal

Pordata (s.d.b). Rendimento médio das famílias. Disponível em https://www.pordata.pt/Portugal/Ren dimento+médio+disponível+das+famílias-2098

Pordata (s.d.c). Poupança bruta em \% rendimento disponível. Disponível em https://www.pordata. pt/Portugal/Poupança+e+ordenados+salários+ no+total+do+rendimento+disponível+dos+part iculares+(percentagem)-710

Portal da Habitação (2018). NGPH. Disponível em https://www.portaldahabitacao.pt/pt/portal/ habitacao/npgh.html

Resolução do Conselho de Ministros n. 0 48/2016 de 1 de Setembro. Diário da República 168/2016 - Série I. Lisboa: Presidência do Conselho de Ministros

SEF (2016). Relatório de imigração, fronteiras e asilo. Disponível em https://sefstat.sef.pt/Docs/ Rifa2016.pdf

SEH (2017). Para uma Nova Geração de Políticas de Habitação: Sentido estratégico, objetivos e instrumentos de atuação. Disponível em https:// www.portugal.gov.pt/download-ficheiros/ficheiro. aspx?v=95621259-fdd4-4099-82f3-2ff17c522882

Žižek, S. (1997). Multiculturalism, or, the cultural logic of multinational capitalism. New Left Review, 225, 28-51.

Žižek, S. (2016). A Europa à deriva: A verdade sobre a crise dos refugiados e o terrorismo. Lisboa: Objectiva.

Sílvia Leiria Viegas (silviaviegas@ces.uc.pt). Bolseira da Fundação para a Ciência e a Tecnologia (SFRH/ /BPD/118022/2016 - FSE/POCH), investigadora de pós-doutoramento do Núcleo de Estudos sobre Cidades, Culturas e Arquitectura do Centro de Estudos Sociais da Universidade de Coimbra (CCArq/CES-UC) e membro do Grupo de Estudos Sócio-Territoriais, Urbanos e de Ação Local da Faculdade de Arquitectura da Universidade de Lisboa (GESTUAL/FA-UL). Colégio de S. Jerónimo, Largo D. Dinis, Apartado 3087, 3000-995 Coimbra. 


\section{PROMOÇÃO DE ESTILOS DE VIDA SAUDÁVEIS: UMA DISTINÇÃO SOCIAL? ${ }^{1}$ PROMOTION OF HEALTHY LIFESTYLES: A SOCIAL DISTINCTION?}

Pedro Saraiva

Centro de Estudos Sociais da Universidade de Coimbra

\section{Resumo}

Nas sociedades capitalistas actuais, os estilos de vida saudável, assim como a ideia de "corpo ideal", como sinal desses estilos, são promovidos através de elaboradas estratégias de marketing. Até que ponto se pode falar em distinção social entre classes na promoção destes estilos de vida? Numa breve reflexão, baseada em literatura científica existente nesta área, discute-se a questão da distinção social na promoção de estilos de vida saudável, com especial enfoque na frequência de ginásios.

Num primeiro momento o debate teórico incide sobre as "sociedades de consumo" e a promoção de estilos de vida saudáveis. Num segundo momento, apresentam-se e discutem-se estudos empíricos que mostram como a distinção social neste âmbito é uma realidade e outros que apontam para a massificação dos produtos e serviços associados aos estilos de vida saudáveis, chegando hoje a um grande número de consumidores com recursos culturais ou económicos variáveis.

Conclui-se que a resposta à questão inicial não é unívoca, mas que são notórios os esforços do capitalismo para que a busca por um corpo perfeito e um estilo de vida saudável se difunda por todas as classes sociais.

Palavras-chave: consumo; saúde; estilos de vida; distinção social

\section{Abstract}

In today's capitalist societies, healthy lifestyles, as well as the idea of "ideal body" as a sign of these styles, are promoted through elaborate marketing strategies. To what extent can one speak of social distinction between classes in the promotion of these lifestyles? In a brief reflection, based on scientific literature in this area, we discuss the issue of social distinction in promoting healthy lifestyles, with special focus on gymnasium attendance.

At first, the theoretical debate focuses on "consumer societies" and the promotion of healthy lifestyles. In a second moment, empirical studies are presented and discussed that show how the social distinction in this scope is a reality and others that point to the massification of the products and services associated to the healthy lifestyles reaching today a large number of consumers with cultural or economic resources.

It is concluded that the answer to the initial question is not univocal, but that the efforts of Capitalism are notorious so that the search for a perfect body and a healthy lifestyle diffuses through all social classes.

Keywords: consumption; health; lifestyles; social distinction

\section{Introdução}

Em pleno século $X X I$, vivemos rodeados de publicidade que apela ao consumo. Consumo esse que deve ser contínuo e regular no tempo. Com esta publicidade, mostra-se aos consumidores como é importante consumir para se atingir um certo nível de satisfação e de felicidade pessoal. Sem esse consumo, não será possível ser-se feliz e ter-se um estilo de vida condigno.

No entanto, vivemos também em sociedades nas quais se generalizou um discurso, inicialmente 
ligado à medicina, sobre a necessidade de ter estilos de vida saudável, para ajudar na prevenção de doenças e para melhorar a qualidade de vida das pessoas (Crawford, 2006, p. 408). Todavia, este discurso, que era exclusivamente médico, deixou de o ser. Pensando que o capitalismo é um sistema económico que põe tudo o que tenha valor, como por exemplo o dinheiro, a trabalhar por forma a produzir lucro económico (Delacroix, 2007, p. 390), este sistema cria novos consumidores, que se mostram cada vez mais preocupados com a sua saúde.

Quando surgiu, este discurso começou pelo aparecimento de novos produtos alimentares, prometendo contribuir para estes estilos de vida saudável tão difundidos pela medicina. No entanto, começa-se a promover igualmente a prática desportiva como outra forma de ajudar a atingir este tipo de estilo de vida. De tal forma que o capitalismo, através de marcas e empresas privadas, com vista à obtenção de lucro económico, cria formas para que as pessoas possam cada vez mais ter mais acesso a vários equipamentos desportivos (como, por exemplo, roupa desportiva) ou, ainda, ginásios desportivos, com uma expansão crescente em todos os países e com cada vez mais modalidades desportivas variadas para serem praticadas.

Estão reunidas as condições essenciais para que os consumidores se possam tornar mais magros, com corpos invejáveis e com menor risco de doenças, ao mesmo tempo que atingem o desejado nível de satisfação e de felicidade pessoal promovido pelo capitalismo.

No entanto, será que esta promoção de estilos de vida saudável não está a criar diferenças entre classes, nomeadamente, entre uma classe alta, que pode pagar para aceder a esses estilos de vida, e uma classe baixa, com rendimentos baixos e que pode ter dificuldades em aceder a esses mesmos estilos? Este ensaio pretende reflectir e discutir sobre a possível distinção social provocada pela promoção de estilos de vida saudável em sociedades de consumo.

É feita, em primeiro lugar, uma exposição possível sobre o que se entende atualmente por "sociedade de consumo", com os contributos de alguns autores que se debruçaram sobre esta matéria, seguida de uma breve exposição da importância de estilos de vida saudável para a saúde. De seguida, segue-se uma exposição sobre a promoção de estilos de vida saudável nestas sociedades, sobretudo focando a questão das idas ao ginásio. Esta escolha pela questão do exercício físico prende-se pela (suposta) facilidade que os consumidores têm em começar a praticar desporto, com maior ou menor intensidade. Além disso, e focando a questão das idas aos ginásios, estes espaços têm surgido com muita regularidade nas nossas cidades, tornando-se, de forma gradual, cada vez mais indispensáveis na nossa luta contínua por estilos de vida mais saudáveis. Por fim, chega-se à devida reflexão sobre a distinção social através da promoção destes estilos de vida saudável, apresentando as devidas conclusões sobre este ensaio.

\section{A sociedade de consumo nos nossos dias}

Nas sociedades de hoje, o acto de consumo é algo que pode ser visto como sendo natural. Como aponta Barbosa, o acto de consumo é "uma atividade presente em toda e qualquer sociedade humana" (2004, p. 7). Ou como Ryan sugere, o consumo está associado aos actos tomados pelos indivíduos, de forma a colmatar necessidades, com estes actos a serem desempenhados sobretudo na sua vida privada (2007, p. 701).

Como tal, o conceito de "sociedade de consumo" surge como um conceito caracterizador das nossas sociedades em pleno século XXI. Ou como Lipovetski afirma: "A ideia de sociedade de consumo soa agora como uma evidência, aparece como uma das figuras mais emblemáticas da ordem econômica e da vida cotidiana das sociedades contemporâneas" (2006, p. 23). No entanto, definir o que tipicamente se expressa por "sociedade de consumo" não é tarefa fácil, bem pelo contrário (Lipovetski, 2006, p. 8), devido às várias abordagens teóricas que se podem tomar. Pode-se mesmo apresentar outros conceitos semelhantes com o mesmo sentido, como é o caso de Zygmunt Bauman.

Bauman fala-nos de "sociedade de consumidores", que para ele "representa o tipo de sociedade que promove, encoraja ou reforça a escolha de um estilo de vida e uma estratégia existencial consumistas, e rejeita todas as opções culturais alternativas" (2007, p. 71). Esta é uma sociedade em que não há reconhecimento de diferenças de idade ou de género (Bauman, 2007, p. 73). Para o autor, o acto de consumo significa o investimento na afiliação social do próprio consumidor, ou seja, obtêm-se qualidades que ainda não se têm ou melhora as que já se têm (Bauman, 2007, p. 75), o que dessa forma permite sair do constrangimento de classe, na medida em que o consumidor se torna um consumidor autónomo.

Ora, esta ideia de consumidor autónomo vem também ao encontro da ideia de hiperconsumo, de que Lipovetski fala. Ou seja, ao mesmo tempo que ficam para trás os constrangimentos de classe, "os consumidores mostram-se mais imprevisíveis e voláteis, mais à espera de qualidade de vida, de comunicação e de saúde, têm melhores condições de fazer uma escolha entre as diferentes propostas da oferta" (2006, p. 41). O consumo foca-se cada vez mais nos gostos particulares e individuais de cada um, em que se procura maximizar o seu consumo. Mais ainda, se pensarmos que os produtos para 
serem consumidos têm uma curta validade (Ryan, 2007, p. 702)

Para se pensar este mesmo consumo, também é preciso não esquecer o papel importante do marketing, destacado por Jean Baudrillard. Como aponta o autor, e embora o consumo seja cada vez individualizado, as várias publicidades que se podem encontrar em todo o lado criam consensos entre as pessoas por forma a que todos sigam os códigos que estão a emergir (1998, p. 125). Vivemos em sociedades em que se promove um consumo contínuo, esperando sempre que o consumidor aumente mesmo o consumo dos seus produtos favoritos, ou que comece o consumo de outros produtos que ainda não conhece. Associado com o marketing, e além de se criar necessidades, cria-se a esperança, ou seja, ao seguir o discurso das campanhas publicitárias, é possível tornar reais as mensagens veiculadas por estas nas rotinas dos consumidores (Baudrillard, 1998, p. 127).

Embora com diferentes abordagens à actual forma de consumo nos nossos dias, todos os autores convergem no mesmo sentido: As nossas sociedades estão transformadas por forma a consumir de forma regular e contínua no tempo, mas em grandes quantidades. Além disso, o consumo é feito de forma individualizada, fugindo aos constrangimentos de classe, permitindo chegar a um maior número de consumidores. De acrescentar, também, o grande papel do marketing para chegar aos consumidores ou potenciais consumidores. Todavia, em paralelo com este consumo, dá-se cada vez mais importância à promoção de estilos de vida saudáveis. Esse é o seguinte ponto a ser discutido neste ensaio.

\section{Importância de estilos de vida saudáveis para a saúde}

A medicina tem um papel central na regulação da vida social, ao distinguir comportamentos saudáveis e não saudáveis que devem ser seguidos pelos indivíduos (Crawford, 2006, p. 404), chamando a atenção dos indivíduos para a necessidade de se ter uma vida saudável, por forma a evitar doenças, através de discursos para a promoção de estilos de vida saudáveis.

Estes discursos surgem na medicina, em face do aumento do número de casos de obesidade, um pouco por todo o mundo. Surgem sobretudo como uma necessidade de combater este problema em particular, ao mesmo tempo que se previnem várias doenças associadas à obesidade e se promove uma melhor qualidade de vida.

No caso da Organização Mundial de Saúde, tem havido uma preocupação em incentivar os seus Estados-membros a delinearem e aplicarem estratégias de promoção de estilos de vida saudável, através da promoção de atividade física
(Organização Mundial de Saúde, 2018, pp. 1- 2). A OMS chega mesmo a publicar, nos seus relatórios, recomendações sobre como a actividade física deve ser executada, por grupos de idade (Organização Mundial de Saúde, 2018, p. 4; 2017, p. 1). A nível nacional e regional, também tem sido adoptado um conjunto crescente de iniciativas, com base nas indicações da OMS (Fortune et al., 2018, p. 623).

Como afirma Costa, "tudo aponta para a falta de hábitos saudáveis e de um estilo de vida activo que permitam alcançar o bem-estar, recuperando a velha máxima mente sã em corpo são [itálico do autor]" (2008, p. 1). O que se confirma pelos dados mais recentes num estudo realizado em Portugal ${ }^{2}$. Tendo em conta estes discursos, o conceito de "saúde" é descrito segundo as condições e, possibilidades para se atingir uma vida saudável, através de várias soluções (Crawford, 2006, p. 404), e, por isso mesmo, é veiculada a necessidade de seguir estilos de vida saudável. Este conceito de "estilos de vida saudável" tem várias vertentes possíveis, mas, seguindo o foco deste artigo, uma dessas vertentes prende-se com a prática de exercício físico.

Dessa forma, este estilo de vida encontra-se associado ao consumo extensivo de produtos e de serviços, como roupa e calçado desportivo, dietas, idas ao ginásio, entre outros (Cockerham, 2007, p. 2061). Como aponta Assumpção et al., "sustenta-se a hipótese da necessidade de se promoverem mudanças no seu estilo de vida, levando-o a incorporar a prática de atividades físicas ao seu cotidiano" (2002, p. 1). Esta ideia prende-se com o discurso da medicina que "associa o estilo de vida saudável ao hábito da prática de atividades físicas e, consequentemente, a melhores padrões de saúde e qualidade de vida" (Assumpção et al., 2002, p. 2). Dessa forma, e mesmo com restrições de tempo, a actividade física deve ser incorporada como uma actividade do quotidiano de cada um de nós (Beaudoin, Fernandez, Wall \& Farley, 2007, p. 2). Os próprios meios de comunicação social têm desempenhado um papel fundamental na divulgação da necessidade de hábitos mais saudáveis, em prol da saúde (Beaudoin et al., 2007, p. 5).

Verifica-se por isso que é necessário promover estilos de vida saudável, que ajudam a combater doenças que diminuem a qualidade de vida das pessoas. Dessa forma, os meios de comunicação social, mas também o próprio marketing, têm um papel fundamental na promoção desses mesmos estilos de vida, como apontam Dixon et al., que defendem que são feitas campanhas por forma a provocar mudanças de comportamento associadas à saúde, incentivando a comportamentos mais saudáveis (2015, p. 1). Como aponta Crawford, uma vida saudável está reduzida a apenas um problema de saúde (1980, p. 381), e, com a adopção destes estilos de vida, este problema será resolvido. 
Tendo em conta todos estes benefícios para a saúde, através da adopção de estilos de vida saudáveis, com a prática de exercício físico de forma regular, cria-se a necessidade de alargar estas práticas ao maior número de pessoas possível. Perante essa necessidade e graças ao papel que o marketing tem no nosso consumo diário, o capitalismo aproveita-se desta situação para promover estes estilos de vida, através do consumo de produtos relacionados com a prática desportiva. Situação essa que será discutida no ponto seguinte, focando particularmente a questão da prática desportiva, no que diz respeito às idas ao ginásio.

\section{Promoção de estilos de vida saudáveis nas nossas sociedades}

Em face da necessidade de promover estilos de vida saudável, para prevenir o aparecimento de doenças, que ameaçam a qualidade de vida das pessoas, o capitalismo surge como o principal aliado da medicina para a promoção e divulgação destes discursos. E faz essa promoção de forma engenhosa, adaptando-se à realidade que surge com o aparecimento destes discursos, aproveitando por exemplo o aumento constante da cultura desportiva da população em geral (Barbosa, 2014, p. 63). Para Rojas, ir ao ginásio é um mero acto de consumismo (2016, p. 277). Verifica-se mesmo o crescimento de uma panóplia de equipamentos (desportivos e não-desportivos) ao dispor do consumidor, como as lojas de produtos naturais, espaços com aparelhos de musculação, salas para aulas de body-pump, ginástica localizada, entre outros (Costa, 2008, p. 1).

Esta também é uma forma de permitir a satisfação do lazer, vista como da "maior importância para o bem-estar das pessoas enquanto indivíduos ou sociedades" (Elias \& Dunning, 1985, p. 106). Com toda a variedade de actividades possíveis de serem realizadas, estas actividades são idealizadas como "votadas ao lazer, no sentido de uma ocupação escolhida livremente e não renumerada - escolhida, antes de tudo, porque é agradável para si mesmo" (Elias \& Dunning, 1985, p. 107). Como defende Lipovetski, as pessoas encontram "o caminho da realização pessoal mais nos prazeres do tempo livre e da vida relacional que no ativismo profissional" (2006, p. 265).

Percebe-se desta forma que é possível ter actividades físicas, associando a ideia de lazer com a ideia de promover um estilo de vida saudável. No entanto, o capitalismo aproveita esta situação para atingir outros objectivos, nomeadamente ao criar uma preocupação em torno dos corpos dos consumidores, com o surgimento de novos produtos e de novas necessidades, tornando-os cada vez mais "um produto privilegiado da lógica industrial" (Assumpção et al., 2002, p. 9).
Criou-se, por isso, a necessidade de os consumidores cuidarem a sua imagem corporal. Ou seja, o capitalismo toldou os consumidores por forma a que estes olhem o seu corpo como uma imagem a manter ou a melhorar, se for caso disso. No estudo realizado por Rojas, aponta-se claramente as idas aos ginásios como forma de as pessoas quererem cada vez mais ter um corpo saudável, livre de gorduras, associado à ideia de ser belo, enérgico e jovem (2016, p. 293). Os próprios meios de comunicação social desempenham um papel fundamental neste caso: "Assiste-se hoje, na televisão, nos jornais e em revistas, a uma verdadeira veneração pelo corpo esculpido, belo e sedutor. Este padrão corporal é produzido e difundido pelos veículos de comunicação. Valoriza-se a aparência, a sedução, o fascínio" (Assumpção et al., 2002, p. 9). O capitalismo criou a ideia do "corpo ideal", sendo necessário passar por determinados processos para atingir aquele mesmo corpo. Há mesmo uma medicalização do consumo, em que se pode recorrer a vários tratamentos médicos para atingir o corpo considerado "ideal", se tal for necessário.

No caso da prática desportiva, nomeadamente as idas ao ginásio, o que era primeiro visto como uma actividade de lazer, é visto agora como uma actividade altamente medicalizada, em que se procura atingir o corpo perfeito, com produtos que permitem perder peso, que aumentam o desempenho desportivo e conservam a juventude, prometendo ajudar a ultrapassar as dificuldades sociais dos indivíduos (Lipovetski, 2006, p. 280). No caso das mulheres, há igualmente a ideia do corpo magro e jovem, no qual a "norma tirânica da magreza leva as mulheres, em particular, a controlar permanentemente o peso e alimentação, a querer remodelar a silhueta a ponto de fazê-las parecer 'escravas da aparência'" (Lipovetski, 2006, p. 276). Há mesmo dados para o caso de Portugal que apontam para esse sentido ${ }^{3}$.

Como observa Baudrillard, o corpo é comparado a um território "virgem" que é colonizado, no qual se vão desenvolver sinais visíveis de felicidade, de saúde e de beleza (1998, p. 131). O corpo é reapropriado por forma a cumprir os objectivos do capitalismo, investindo-se nele por forma a obter uma produção própria (Baudrillard, 1998). Além disso, o trabalho que é feito com o corpo é visto como essencial para a identidade pessoal de cada um de nós, mas também como uma forma de atingir status social (Wachs, 2007, p. 710).

Em face da necessidade de promoção de estilos de vida saudáveis, e como forma de contrariar o alastramento de doenças e de forma a garantir a qualidade de vida dos consumidores, cria-se um "corpo exemplo", no qual se mostra que para atingir a felicidade é preciso trabalhar cumprindo certas normas e consumindo determinados produtos. Mas 
os consumidores deixam de controlar o seu corpo, que passa a ser controlado pelo capitalismo, que molda os corpos como bem entende.

No fundo, o capitalismo criou a necessidade de cuidado da nossa imagem, porque essa imagem reflecte o que são os consumidores enquanto pessoas. Para se atingir o nível de satisfação e felicidade pessoal que o capitalismo promete, é preciso transformar e cuidar do corpo. Só assim se pode atingir a ambicionada felicidade, tão vastamente prometida. Como afirma Assumpção et al.: "A lógica de mercado determina o estilo de vida considerado 'saudável' bem como os padrões de comportamento e os modelos de corpo que devem ser vendidos e consumidos pelas diferentes classes sociais" (2002, p. 9). Como aponta a citação ("vendidos e consumidos pelas diferentes classes sociais"), pressupõe que poderá haver consumos diferenciados para diferentes classes sociais. Dessa forma, será que todos os consumidores poderão ter acesso a esta felicidade pessoal, através da transformação corporal?

Para poder praticar exercício físico num ginásio de forma regular, por forma a atingir o "corpo ideal", é necessário um grande investimento financeiro por parte dos consumidores. Investimento não só nas mensalidades do ginásio, como também no equipamento desportivo, nos suplementos desportivos, entre outros. Investimentos esses que podem não estar acessíveis a todos. Esta é a discussão que será realizada de seguida.

\section{Promoção de distinção social?}

Devido ao grande investimento financeiro necessário para atingir a transformação corporal necessária para conseguir a tão desejada felicidade, promovida pelo capitalismo, nem todos os consumidores poderão ter os recursos financeiros para atingir isto. Será que se pode falar numa distinção entre uma classe alta, com elevados recursos culturais e financeiros que permitem praticar exercício físico num ginásio e fazer outros investimentos associados, por forma a atingir o "corpo ideal", e uma classe baixa, que não dispõe dos mesmos recursos, e que por isso não tem possibilidade de procurar atingir esse mesmo "corpo"? Esta é uma pergunta que, à partida, parece fácil de responder.

No entanto, o que se pode entender por distinção? Como é que ela se pode manifestar? Holt apresenta os seus argumentos, afirmando que tudo aquilo que as pessoas consomem expressa gostos, ou seja, os gostos que as pessoas têm agem como mecanismos de reprodução e distinção social, reproduzindo diferenças entre as várias classes sociais (2007, p. 1189).

Pierre Bourdieu, na sua obra $A$ Distinção, defende que o conhecimento que temos do mundo social se serve de esquemas que permitem classifi- cações, ou seja, "esquemas históricos de percepção e apreciação que são o produto da divisão objetiva em classes (faixas etárias, classes sexuais, classes sociais) e que funcionam aquém da consciência e do discurso" (2007, p. 436). Leão et al., numa pesquisa no Brasil, identificaram que "parte significativa do significado atribuído às marcas pelos consumidores passa pela compreensão delas como signos estatutários; uma forma de estabelecer hierarquia entre as pessoas" (2014, p. 89). Para os autores, é mesmo uma "estratégia de manutenção de poder daquelas dominantes sobre as demais" (Leão et al., 2014, p. 90).

Podemos por isso definir o conceito de distinção social, como apresentado por Williams ${ }^{4}$, como um fenómeno social que, baseado em normas sociais vigentes, promove a diferenciação entre os indivíduos, através de vários critérios, como a idade, o sexo, a religião, entre outros (2007, p. 4406). Pode-se acrescentar outros critérios, como os gostos, o que cada um come, o que cada um veste, onde cada um gosta de relaxar (Giddens, 2006, p. 322). Todos estes critérios promovem distinção entre os indivíduos e, por isso mesmo, distinção entre classes sociais.

Se pensarmos que o consumo de produtos e serviços é criado por forma a que seja global, pode-se mesmo falar em dois níveis distintos de consumo, sendo que, por um lado, há um consumo que permite atingir prestígio e poder, e outro que corresponde a necessidades sociais (Ryan, 2007, p. 702).

Ora, se pensarmos que a classe baixa tem uma preocupação em suprimir estas "necessidades sociais", que se traduzem em necessidades básicas, como alimentação, alojamento, saúde, entre outros exemplos, poderá apontar-se então para uma distinção entre uma classe que procura competir pelo poder e status, que se materializa através de um consumo individualizado (elementos de classe alta), e uma classe que não procura poder, mas sim satisfazer necessidades básicas diárias, que acabam por ser comuns entre os seus membros (elementos de classe baixa). No caso dos elementos da classe alta, poder-se-á afirmar que o consumo surge como uma necessidade de aumentar o seu status social, tendo presente a necessidade de se distinguir de outros actores sociais (Schor, 2007, p. 683).

Cockerham aponta igualmente neste sentido, completando as ideias dos autores anteriores, ao afirmar que os estilos de vida são baseados nos consumos realizados, uma vez que o consumo de determinados produtos ou serviços mostram o status dos seus consumidores (2007, p. 2061).

Poder-se-ia apontar claramente que sim. Existe uma distinção social entre a classe alta e a classe baixa sobre o acesso a estilos de vida saudáveis e, consequentemente, ao "corpo ideal" promovido pelo capitalismo. Um estudo realizado por Bakcken- 
-Ulseth \& Seippel, num ginásio, aponta claramente o rendimento como um factor de distinção social entre as pessoas que frequentam o ginásio estudado (2011, p. 14). No entanto, como ambas as autoras também reconhecem, existem muitos outros factores que desconhecem e que podem ou não causar distinção social (Bakcken-Ulseth \& Seippel, 2011, p. 14). Num outro estudo realizado sobre a ida aos ginásios, Rojas afirma que a ida ao ginásio permite desenvolver e reforçar a identidade de quem o frequenta (2016, p. 294). Ora, diferentes utilizadores de diferentes classes vão moldar a sua identidade, quer pertençam à classe alta, quer à classe baixa.

Mas, por outro lado, não se pode afirmar totalmente que existe distinção social entre classes aquando do momento de frequentar ginásios e de procurar o "corpo ideal". Existem outros aspetos a ter em conta e que devem também ser alvo de reflexão e que aqui não são discutidos. Um exemplo relevante prende-se com as dietas alimentares, complementadas por suplementos alimentares, que são cada vez mais usadas por quem pretende perder peso e atingir o "corpo ideal".

Pode-se até apontar que estes mesmos estilos de vida foram massificados pelo capitalismo por forma a chegar a um maior número de consumidores, independentemente dos recursos culturais ou financeiros de que possam dispor. O exemplo que se pode dar é a massificação do uso de roupa e calçado desportivo. Inicialmente, este tipo de roupa e calçado era dispendioso e não era acessível a todas as pessoas. No entanto, com o aparecimento de grandes superfícies comerciais dedicadas à promoção de desporto, um pouco por todo o lado e com preços baixos, torna-se acessível a todo o tipo de consumidores, podendo-se mesmo falar de uma massificação deste tipo de equipamento desportivo. Tendo acesso a este tipo de roupa, essencial para a prática de exercício físico em ginásios, o acesso a estes espaços torna-se igualmente mais fácil.

Vistos como locais de estabelecimento de laços sociais entre as pessoas, também eram vistos como locais onde as pessoas que tivessem maiores recursos culturais e financeiros se poderiam encontrar, ao mesmo tempo que iriam transformar o corpo por forma a atingir o corpo saudável, tão badalado pelo capitalismo. No entanto, as idas ao ginásio também se massificaram, com o aparecimento contínuo de novos ginásios, com preços cada vez mais acessíveis, para atingir um maior número de consumidores possível, verificando-se mesmo um aumento de número de utilizadores destes espaços ${ }^{5}$.

Acrescenta-se igualmente o facto de os ginásios terem várias modalidades desportivas, praticadas através de aulas de grupo com acompanhamento de instrutores personalizados, o que permite que estes novos consumidores praticamente "se sintam em casa". Associado à prática de desporto em ginásio, facilita também o aparecimento de grandes eventos como o Portugal $\mathrm{Fit}^{6}$, considerado o maior evento de fitness e de promoção de estilos de vida saudáveis em Portugal e realizado uma vez por ano, que permite divulgar a mensagem de que todos os consumidores, independentemente dos recursos de que disponham, podem e sobretudo devem frequentar os ginásios, para bem da sua saúde.

Para Lipovetski (2006), percebe-se que a distinção social, no que diz respeito ao consumo, é inexistente:

"Não é mais a oposição entre a elite dos dominantes e a massa dos dominados, nem aquela entre as diferentes frações de classe que organiza a ordem do consumo, mas o 'sempre mais' e o zapping generalizado, as bulimias exponenciais de cuidados, de comunicações e de evasões renovadas." (p. 43)

\section{Conclusão}

Em face dos vários problemas de saúde ligados aos maus hábitos alimentares, mas também ligados ao sedentarismo e à obesidade, um pouco por todo o mundo, têm sido difundidos discursos para a necessidade de adopção de estilos de vida saudáveis, que incluam o consumo de alimentos considerados saudáveis e a prática contínua de exercício físico. Estes discursos são carregados de lógicas que pressupõem que a adopção destes estilos de vida permite a melhoria da qualidade de vida das pessoas, e a consequente melhoria da felicidade pessoal.

Focando a atenção na prática desportiva em ginásios, o capitalismo, tal como em outras fases anteriores da História, conseguiu adaptar-se a estes discursos, criando mecanismos próprios para aumentar o consumo de produtos e serviços relacionados com a adopção e manutenção de estilos de vida saudável, apostando, por exemplo, na massificação de espaços desportivos, como os ginásios, e, na consequente redução das mensalidades ou novas formas de pagamento destas mesmas idas (pagamento semanal em vez de pagamento mensal).

Aproveitando o facto de o desporto ser visto como uma actividade de lazer e de prática saudável, o capitalismo aproveitou bem este facto para se expandir através desta prática, chegando às pessoas.

Espaços como ginásios e locais semelhantes são vistos como locais de consumo, onde cada consumidor se cria ou se reinventa a si mesmo, marcando a existência de uma identidade, com marcadores ligados à etnicidade e género, ligados a estilos específicos de consumo (Rojas, 2016, p. 294).

Associado a esta prática desportiva, percebe-se que as pessoas têm vindo a procurar o "corpo ideal", com determinadas características, que iria 
permitir aos consumidores atingir um alto nível de satisfação e felicidade pessoal, conforme veicula o capitalismo. Sobretudo se se tiver em conta a promoção de uma cultura visual de âmbito público (como, por exemplo, o cinema), que alerta para a importância da aparência externa, mas sobretudo para os cuidados com o corpo (Wachs, 2007, p. 709).

No entanto, em face deste contexto, a reflexão principal foi sobre a possível distinção social entre classes no que diz respeito ao acesso a estes mesmos estilos de vida. Apesar de os autores aqui citados, e os estudos realizados nos seus países, apontarem para a existência de distinção social entre quem pode atingir ou não o "corpo ideal", não se poderá dizer que existe uma clara distinção social, mas também não se pode afirmar que esta não existe.

Embora se possa afirmar que o capitalismo tem vindo a procurar formas de se adaptar a estes novos estilos de vida, são necessários estudos que comprovem a existência, ou não, de distinção social, no momento da busca pelo "corpo ideal".

Pode-se, no entanto, afirmar que o capitalismo molda estas mesmas pessoas, independentemente da classe social a que pertencem, de forma que sigam as normas que impõe, consumindo aquilo que o capitalismo quer, tentando eliminar a distinção social que possa existir entre as pessoas. Todos os mecanismos de distinção que possam existir poderão ser esbatidos por forma a que desapareçam, criando a ilusão de que são consumidores livres e conscientes.

\section{Notas}

1 Este texto foi realizado no âmbito de uma Bolsa de Doutoramento da Fundação para a Ciência e a Tecnologia (ref.a SFRH/BD/137480/2018), financiada pelo Fundo Social Europeu e por fundos nacionais do Ministério de Ciência, Tecnologia e Ensino Superior de Portugal.

2 Para mais informações, consultar a notícia do Diário de Notícias: https://www.dn.pt/sociedade/interior/ portugueses-estao-a-beber-e-a-fumar-menos-mas-sao-mais-gordos-e-inativos-8940036.html

3 Para mais informações, consultar o estudo realizado pela Marktest: http://www. marktest.com/wap/a/n/id 21d1. aspx

4 Apesar de ser feita referência ao conceito de "distância social", é apenas uma outra forma de fazer referência ao conceito de "distinção social", de uma maneira ou de outra, referem-se sempre ao mesmo fenómeno social.

5 Para dados em concreto, consultar o estudo realizado pela Marktest: http://www.marktest.com/wap/a/n/id 211a. aspx

6 Para mais informações sobre este evento, consultar: http://arena.altice.pt/agenda/portugalfit_pt/2670/ e http://www.portugalfit.pt/

\section{Referências bibliográficas}

Assumpção, L. O. T., Morais, P. P., \& Fontoura, H. (2002). Relação entre atividade física, saúde e qualidade de vida. Notas introdutórias. Revista Digital Buenos Aires, 52(8). Disponível em http://www.efdeportes. com/efd52/saude.htm

Bakcken-Ulseth, A. L., \& Seippel, O. (2011). Fitness, Class and Culture: Social Inequality in Fitness. Nordic Sport Science Forum, 1-17. Disponível em http://idrottsforum.org/articles/ulseth_seippel/ ulseth_seippel111123.pdf

Barbosa, L. (2004). Sociedade de Consumo. Rio de Janeiro, Brasil: Jorge Zahar Ed.

Barbosa, S. (2014). Relatório de Atividade Profissional no Forlife, Desporto e Bem-Estar. (Relatório de Mestrado, Instituto Politécnico da Guarda.) Disponível em http://bdigital.ipg.pt/dspace/ bitstream/10314/2237/1/MKTC_Sandra\%20 Barbosa.pdf

Baudrillard, J. (1998). The Consumer Society. Londres, Inglaterra: SAGE Publications Ltd.

Bauman, Z. (2007). Vida para Consumo. A transformação das pessoas em mercadoria. Rio de Janeiro, Brasil: Jorge Zahar Ed.

Beaudoin, C. E., Fernandez, C., Wall, J. L., \& Farley, T. A. (2007). Promoting Healthy Eating and Physical Activity. Short-Term Effects of a Mass Media Campaign. American Journal of Preventive Medicine, 32(3), 217-223. Disponível em http://www.sciencedirect.com/science/article/pii/ S0749379706004934

Bourdieu, P. (2007). A Distinção. Porto Alegre, Brasil: Zouk.

Cockerham, W. C. (2007). Health Lifestyle. In G. Ritzer (Ed.), The Blackwell Encyclopedia of Sociology (pp. 2061-2063). Malden, EUA: Blackwell Publishing, Ltd.

Costa, M. (2008). Valor da Marca no Fitness: estudo da Imagem e das Associações à Marca na Lealdade. (Dissertação de Mestrado, Universidade Técnica de Lisboa.) Disponível em https://repositorio. iscte-iul.pt/bitstream/10071/1691/1/Valor_da_ Marca_no_Fitness_MarisaCosta.pdf

Crawford, R. (1980). Healthism and The Medicalization of Everyday Life. International Journal of Health Services, 10(3), 365-388. Disponível em https:// journals.sagepub.com/doi/abs/10.2190/3H2H3XJN-3KAY-G9NY?journalCode $=$ joha

Crawford, R. (2006). Health as a meaningful social practice. Health: An Interdisciplinary Journal for the Social Study of Health, Illness and Medicine, 10(4), 401-420. Disponível em http://journals. sagepub.com/doi/abs/10.1177/1363459306067 310?journalCode $=$ heaa

Delacroix, J. (2007). Capitalism. In G. Ritzer (Ed.), The Blackwell Encyclopedia of Sociology (pp. 390-395). Malden, EUA: Blackwell Publishing, Ltd.

Dixon, H., Scully, M., Cotter, T., Maloney, S., \& Wakefield, M. (2015). Healthy weight and lifestyle advertise- 
ments: an assessment of their persuasive potential. Health Education Research, 30(4), 569-579. Disponível em https://academic.oup.com/her/ article-lookup/doi/10.1093/her/cyv031

Elias, N., \& Dunning, E. (1985). A Busca da Excitação. Lisboa, Portugal: Difel.

Fortune, K., Becerra-Posada, F., Buss, P., Galvão, L. A. C., Contreras, A., Murphy, M., Rogger, C., Keahon, G. E., \& de Francisco, A. (2018). Health promotion and the agenda for sustainable development, WHO Region of the Americas. Bulletin of the World Health Organization, 96, 621-626. Disponível em http://www.who.int/bulletin/volumes/96/9/17-204404.pdf.

Giddens, A. (2006). Sociology (Fifth Edition). Cambridge, Inglaterra: Polity Press.

Holt, D. B. (2007). Distinction. In G. Ritzer (Ed.), The Blackwell Encyclopedia of Sociology (pp. 11891191). Malden, EUA: Blackwell Publishing, Ltd.

Leão, A., Mello, S., \& Gaião, B. (2014). Uso das Marcas na Vida Cotidiana como Busca por Distinção Social. Organizações em contexto, 10(20), 85-116. Disponível em http://dx.doi.org/10.15603/19828756/roc.v10n20p85-116

Lipovetski, G. (2006). A Felicidade Paradoxal. Ensaio sobre a felicidade de hiperconsumo. São Paulo, Brasil: Companhia das Letras.

Organização Mundial de Saúde (2018). Status report on "PHYSICAL ACTIVITY and HEALTH in the South-East Asia Region". Nova Deli, Índia: Gabinete Regional para o Leste e Sul da Ásia da Organização Mundial de Saúde. Disponível em http://apps.who.int/iris/ bitstream/handle/10665/274308/9789290226697-eng.pdf? sequence $=1$ \&isAllowed $=y$

Organização Mundial de Saúde (2017). An effective approach to early action on noncommunicable disease risk factors. Genebra, Suíça: Sede geral da Organização Mundial de Saúde. Disponível em http://apps.who.int/iris/bitstream/handle/10665/255625/WHO-NMH-PND-17.3-eng. pdf? sequence $=1$ \&isAllowed $=y$

Rojas, A. S. (2016). I'm super-setting my life! An ethnographic comparative analysis of the growth of the gym market. Sport Science Review, 35(5-6), 321-344. Disponível em https://www.degruyter. com/view/j/ssr.2016.25.issue-5-6/ssr-2016-0015/ ssr-2016-0015.xml

Ryan, M. T. (2007). Consumption. In G. Ritzer (Ed.), The Blackwell Encyclopedia of Sociology (pp. 701-705). Malden, EUA: Blackwell Publishing, Ltd.

Schor, J. B. (2007). Conspicuous Consumption. In G. Ritzer (Ed.), The Blackwell Encyclopedia of Sociology (pp. 681-686). Malden, EUA: Blackwell Publishing, Ltd.

Wachs, F. L. (2007). Consumption And The Body. In G. Ritzer (Ed.), The Blackwell Encyclopedia of Sociology (pp. 709-712). Malden, EUA: Blackwell Publishing, Ltd.

Williams, J. E. (2007). Social Distance. In G. Ritzer (Ed.) The Blackwell Encyclopedia of Sociology (pp. 44064407). Malden, EUA: Blackwell Publishing, Ltd. 


\section{INFORMAÇÕES AOS AUTORES}

\section{NORMAS PARA APRESENTAÇÃO DE ORIGINAIS}

A revista Forum Sociológico publica artigos originais, entrevistas, recensões críticas e documentos. Todos os originais propostos para publicação na revista Forum Sociológico devem ser enviados para o endereço eletrónico da revista (forum@fcsh.unl.pt).

É política editorial da Forum Sociológico respeitar a opção ortográfica dos autores que publica. Os artigos originais têm de ser inéditos e não podem estar a ser submetidos para publicação em outras revistas nacionais e internacionais. Devem ter no máximo 40000 caracteres (incluindo espaços, resumos, notas de rodapé, bibliografia, quadros, gráficos e figuras, o que perfaz cerca de 18 páginas), e só serão considerados para a avaliação científica caso os autores não ultrapassem o limite de caracteres estipulado.

Os artigos podem integrar-se nos dossiês temáticos ou ser publicados na secção "Outros artigos". Os artigos propostos para publicação são submetidos a parecer de especialistas em regime de anonimato bilateral. A decisão final da publicação é da responsabilidade do Conselho de Redação.

Promove-se também a publicação de entrevistas a especialistas sobre temas relevantes no âmbito das Ciências Sociais, bem como recensões críticas de obras recentemente publicadas no país e no estrangeiro, cujas temáticas sejam pertinentes no âmbito científico de publicação da revista. Serão também aceites documentos, notas analíticas e conclusivas resultantes de trabalhos de investigação, e outros documentos considerados relevantes que não se enquadram no formato previsto para os artigos.

Cada texto deverá apresentar o(s) nome(s) do(s) autor(es), email(s) de contacto e respetiva(s) afiliação(ões) institucional(is) indicada(s) a três níveis (Universidade, Faculdade ou Escola, Departamento ou Centro). Os textos deverão iniciar-se com um título e resumo no idioma do texto e no idioma português e inglês, caso este não seja escrito nesses idiomas, com um máximo de 1000 caracteres (10 linhas), seguidos de 3 ou 4 palavras-chave nesses mesmos idiomas e da indicação do número de caracteres (com espaços).

Os textos devem ser apresentados em páginas A4, a espaço e meio (norma também válida para a bibliografia), em tipo de letra Times New Roman, tamanho $12 \mathrm{com}$ as margens superior, inferior esquerda e direita a $2 \mathrm{~cm}$. Os quadros, gráficos e figuras deverão ser numerados de forma contínua, em numeração árabe, para cada um dos elementos respetivos (Quadro 1; Gráfico 1; Figura 1). As citações e referências bibliográficas devem seguir a norma de citação APA $6^{\text {th }}$ Edition.

\section{PROCESSO DE ARBITRAgEM CIENTIFICA E DECISÃO SOBRE PUBUICAÇ̃̃o DOS ARTIGOS}

O Conselho de Redação reserva-se o direito de publicar/não publicar os artigos recebidos, comprometendo-se a informar os autores sobre a decisão. A decisão é apoiada num processo de apreciação dos artigos com base num sistema anónimo de arbitragem científica realizado em duas fases sucessivas:

1. Os artigos propostos são submetidos a uma primeira análise por parte do Conselho de Redação, que decide sobre a passagem dos artigos à fase seguinte de submissão a parecer de especialistas. Esta decisão tem em consideração a pertinência, o interesse e a qualidade dos artigos, assim como os critérios definidos de acordo com a política editorial da revista e as normas para a apresentação de originais.

2. Os artigos selecionados na primeira fase são submetidos ao parecer de avaliadores, num mínimo de 2 , em regime de anonimato bilateral. Os pareceres dos avaliadores irão fundamentar a decisão final do Conselho de Redação no que respeita à publicação dos respetivos artigos.

O Conselho de Redação envia os pareceres dos avaliadores aos autores de forma anónima, sugerindo a realização das alterações ou correções propostas nos referidos pareceres, podendo condicionar a 
publicação dos artigos a uma nova apreciação das versões revistas.

Caso os artigos que passem à segunda fase de apreciação não sejam aceites para publicação, a Forum Sociológico informará os autores acerca dos motivos dessa decisão, podendo enviar os respetivos pareceres dos avaliadores.
A decisão final de publicação é da responsabilidade do Conselho de Redação, com base nos pareceres emitidos pelos avaliadores e a partir de critérios previamente estabelecidos pelo Conselho de Redação.

Os textos publicados são da responsabilidade dos respetivos autores.

\section{NORMAS PARA APRESENTAÇÃO DE DOSSIÊS TEMÁTICOS}

A Forum Sociológico poderá publicar dossiês temáticos sobre temas relevantes no âmbito das Ciências Sociais.

As propostas de dossiês temáticos deverão ser enviadas para o email da revista (forum@fcsh.unl.pt) e deverão conter as seguintes informações:

- Título proposto para o dossiê;

- Nome do(s) coordenador(es) do dossiê juntamente com a(s) sua(s) respetiva(s) afiliação(ões) institucional(is), indicada(s) a três níveis (Universidade, Faculdade; Departamento ou Centro), e email(s) de contacto;

- Um pequeno texto de apresentação que identifique o tema do dossiê, a sua relevância e articulação com o domínio científico de publicação da Forum Sociológico.

A coordenação deverá indicar uma data prevista para a publicação do dossiê e também para a entrega dos artigos e deverá informar o número de artigos previstos para o dossiê;

As propostas de artigos deverão ser enviadas para o email da revista (forum@fcsh.unl.pt) e deverão cumprir as normas de publicação adotadas pela revista.

Todos os artigos propostos serão submetidos ao processo de arbitragem científica da revista. A coordenação ficará responsável pela seleção de pelo menos dois árbitros científicos por artigo, os quais fi- cam sujeitos à aprovação do Conselho de Redação. Cada um dos coordenadores poderá avaliar apenas um artigo;

A revista ficará responsável pela gestão do processo de avaliação científica (receção de artigos; envio de convite aos árbitros científicos; envio de pareceres aos autores; envio de artigos ao(s) coordenador(es) do dossiê);

Os artigos a integrar os dossiês temáticos serão publicados segundo os critérios do processo de arbitragem científica adotados pela revista. Em complemento, a coordenação do dossiê poderá fazer convites de publicação a especialistas no domínio em causa, os quais ficam sujeitos à aprovação do Conselho de Redação;

No caso de os árbitros científicos sugerirem aos autores alterações ou correções, o Conselho de Redação zelará pela efetiva introdução das mesmas. A decisão final de publicação é da responsabilidade do Conselho de Redação, com base nos pareceres emitidos pelos referees, a partir de critérios previamente estabelecidos pela revista;

A coordenação ficará responsável pela organização e revisão final dos artigos a serem publicados e por escreverem o Editorial;

A publicação do dossiê temático no ano em que é feita a sua submissão estará sempre dependente do calendário da revista planeado pelo Conselho de Redação.

\section{Morada:}

Revista Forum Sociológico

CICS.NOVA - Centro Interdisciplinar de Ciências Sociais

Edifício I\&D, Avenida de Berna, 2

1069-061 Lisboa, Portugal.

E-mail: forum@fcsh.unl.pt

Telefone: 00351217908300 (ext. 1488) 